and

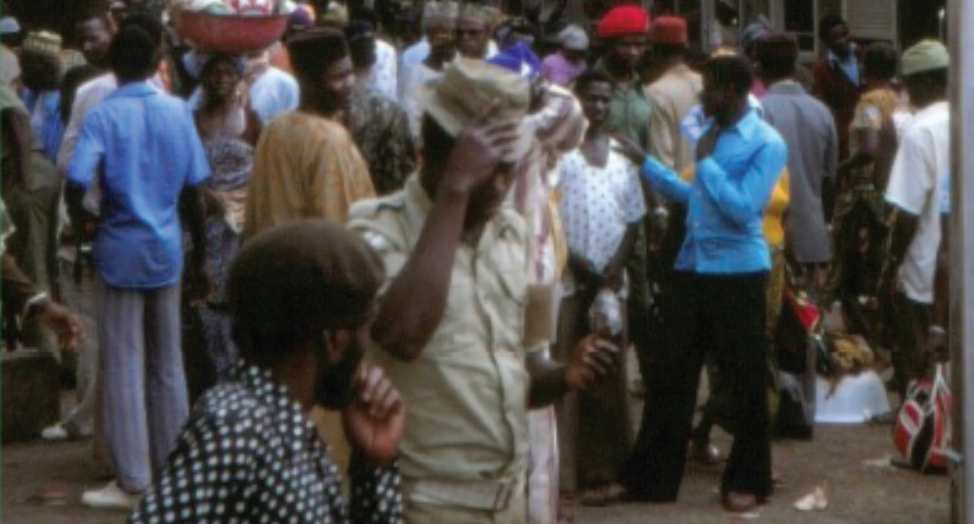

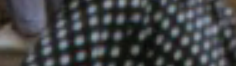

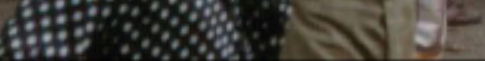

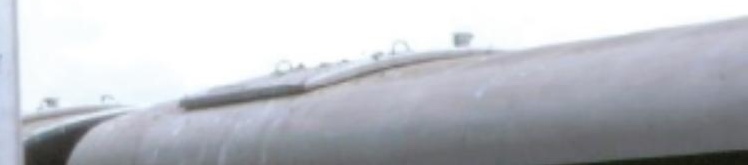

Ulf Hannerz

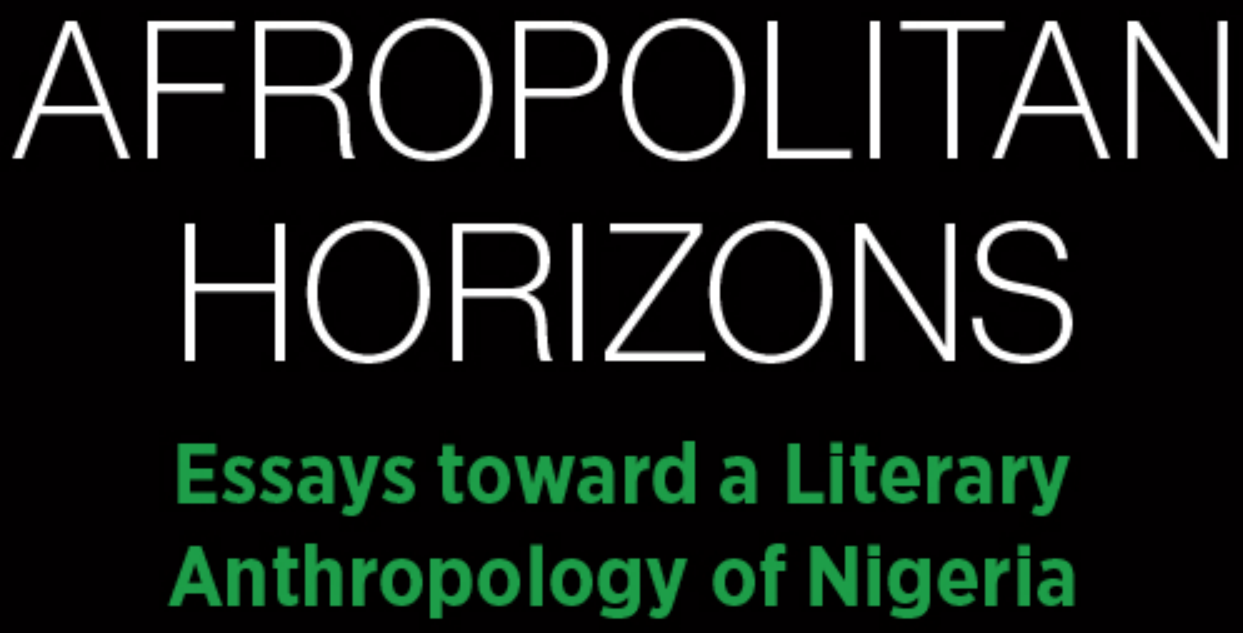





\section{AFROPOLITAN HORIZONS}




\title{
Afropolitan Horizons Essays toward a Literary Anthropology of Nigeria
}

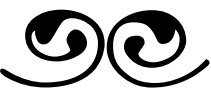

\author{
Ulf Hannerz
}

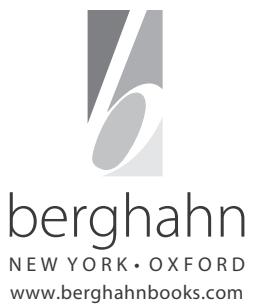


First published in 2022 by

Berghahn Books

www.berghahnbooks.com

\section{(C) 2022 Ulf Hannerz}

All rights reserved. Except for the quotation of short passages for the purposes of criticism and review, no part of this book may be reproduced in any form or by any means, electronic or mechanical, including photocopying, recording, or any information storage and retrieval system now known or to be invented, without written permission of the publisher.

\section{Library of Congress Cataloging-in-Publication Data}

Names: Hannerz, Ulf, author.

Title: Afropolitan Horizons: Essays toward a Literary Anthropology of Nigeria / Ulf Hannerz.

Description: New York: Berghahn Books, 2022. I Includes bibliographical references and index.

Identifiers: LCCN 2021039745 (print) | LCCN 2021039746 (ebook) | ISBN 9781800732506 (hardback) | ISBN 9781800733190 (paperback) | ISBN 9781800732995 (open access ebook)

Subjects: LCSH: Nigerian fiction (English)—20th century-History and criticism. I Nigerian fiction (English)-21st century-History and criticism. | African diaspora in literature. I Nigeria-In literature. | Nigeria-Social life and customs - 20th century. I Nigeria-Social life and customs-21st century.

Classification: LCC PR9387 .H36 2022 (print) I LCC PR9387 (ebook) I DDC $823.009 / 9669-\mathrm{dc} 23$

LC record available at https://lccn.loc.gov/2021039745

LC ebook record available at https://lccn.loc.gov/2021039746

\section{British Library Cataloguing in Publication Data}

A catalogue record for this book is available from the British Library

ISBN 978-1-80073-250-6 hardback

ISBN 978-1-80073-319-0 paperback

ISBN 978-1-80073-299-5 open access ebook

https://doi.org/10.3167/9781800732506

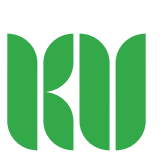

An electronic version of this book is freely available thanks to the support of libraries working with Knowledge Unlatched. KU is a collaborative initiative designed to make high-quality books Open Access for the public good. More information about the initiative and links to the Open Access version can be found at knowledgeunlatched.org.

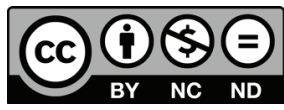

This work is published subject to a Creative Commons Attribution Noncommercial No Derivatives 4.0 License. The terms of the license can be found at http://creativecommons. org/licenses/by-nc-nd/4.0/. For uses beyond those covered in the license contact Berghahn Books. 


\section{Contents}

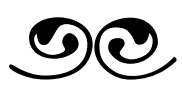

Acknowledgments vii

Introduction. Nigerian Connections $\quad 1$

Chapter 1. Palm Wine, Amos Tutuola, and a Literary Gatekeeper 28

Chapter 2. Bahia-Lagos-Ouidah: Mariana's Story 38

Chapter 3. Igbo Life, Past and Present: Three Views 47

Chapter 4. Inland, Upriver with the Empire: Borrioboola-Gha 57

Chapter 5. The City, According to Ekwensi . . . and Onuzo 66

Chapter 6. Points of Cultural Geography: Ibadan . . . Enugu, Onitsha, Nsukka 76

Chapter 7. Been-To: Dreams, Disappointments, Departures, and Returns $\quad 90$

Chapter 8. Dateline Lagos: Reporting on Nigeria to the World 98

Chapter 9. Death in Lagos 105

Chapter 10. Tai Solarin: On Colonial Power, Schools, Work Ethic, Religion, and the Press 113

Chapter 11. Wole Soyinka, Leo Frobenius, and the Ori Olokun 119

Chapter 12. A Voice from the Purdah: Baba of Karo 129

Chapter 13. Bauchi: The Academic and the Imam 136

Chapter 14. Railtown Writers 144

$\begin{array}{ll}\text { Chapter 15. Nigeria at War } & 149\end{array}$ 
Chapter 16. America Observed: With Nigerian Eyes

Chapter 17. Transatlantic Shuttle 177

Chapter 18. Sojourners from Black Britain 193

Chapter 19. Oyotunji Village, South Carolina:

Reverse Afropolitanism 208

Index 219 


\section{Acknowledgments}

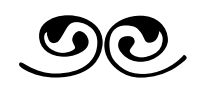

As I reminisce about the people who helped me on the way to this book, I think, first of all, of Victor Olorunsola. Victor and I met as graduate students at Indiana University, Bloomington, in the early 1960s, in the African Studies Program. The last time we met was some twenty years later, in Ames, Iowa, on another university campus, where he was a political science professor. A couple of years later, I learned of his death. His remains came to rest in a burial ground on a slope in the Rocky Mountains - this son of the West African rain forest had become a skiing enthusiast. For me, he was a pioneer Afropolitan.

I am grateful to a number of friends and colleagues whom I have talked with about this book project, or who have read the manuscript, or parts of it, in one version or other, and who have made helpful comments: Akinwumi Adesokan, Thomas Fillitz, Andre Gingrich, Bernth Lindfors, Lorand Matory, Deborah Reed-Danahay, Roger Sanjek, Jesse Weaver Shipley, and Paula Uimonen.

I have also discussed Nigerian writing and its literary anthropology in lectures and other kinds of presentations at the American Anthropological Association; Indiana University; the Hong Kong Anthropological Society; and the Department of Social Anthropology, Stockholm University. The comments from my audiences on these occasions were interesting and inspiring.

I want to thank Stefan Ene and Thomas Borén of the Department of Human Geography, Stockholm University, for advice and expertise in creating a map of Nigeria connecting directly to the contents of the book.

Let me note that in certain places in the text, I have omitted precise page references for quotations. These are basically quotations included to convey a sense of style and atmosphere (not factual information or 
analytical argument), and inserting a standard academic style of referencing here would only seem to distract.

And then, most importantly, my spouse and colleague Helena Wulff has followed and supported this project from beginning to end, while at the same time continuing her own research and writing in literary anthropology. As always, thank you! 


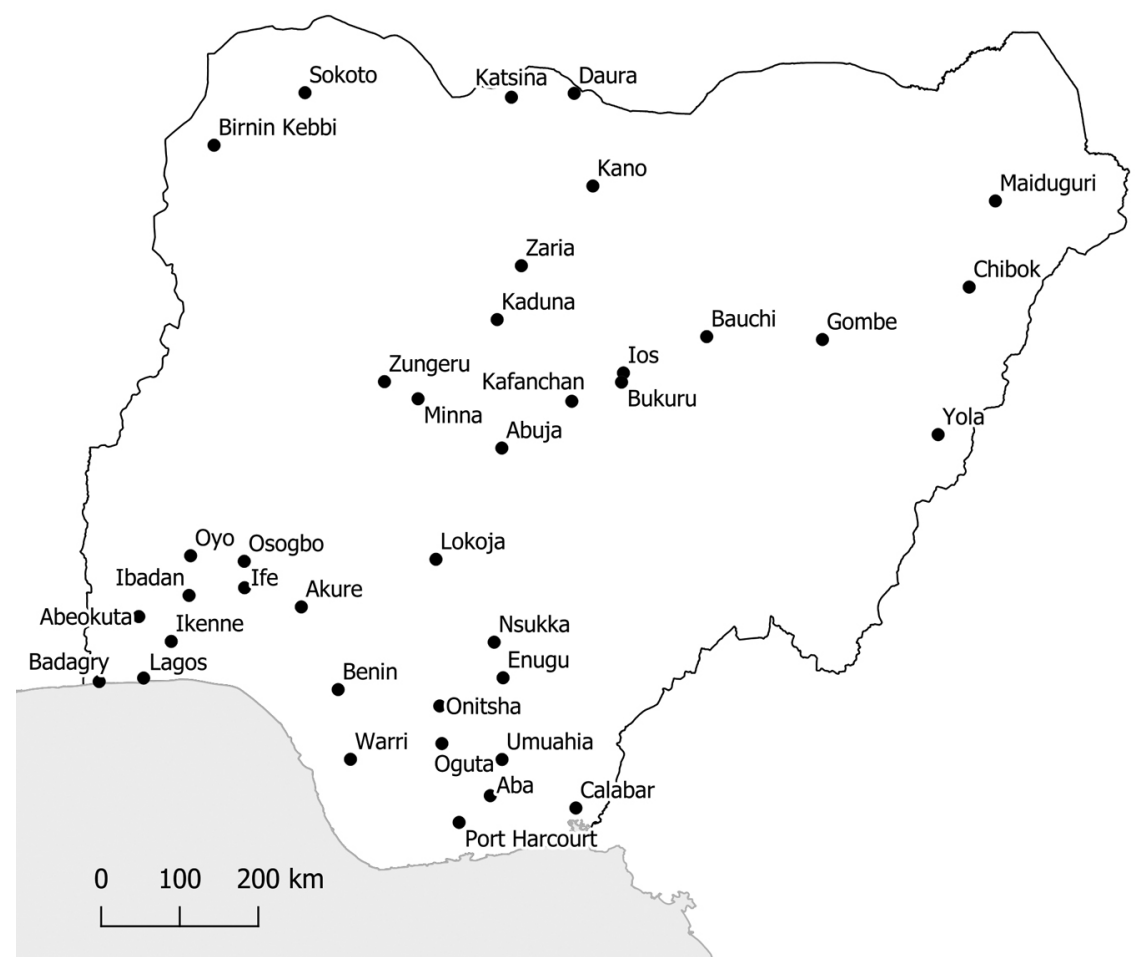

Map of Nigeria, showing places mentioned in the book. Map created by Stefan Ene, Department of Human Geography, Stockholm University. 


\section{INTRODUCTION \\ Nigerian Connections}

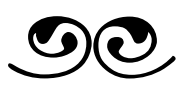

What this book is not: it is not a comprehensive overview of Nigerian literature. That would better be left to a professional scholar of literature, probably a Nigerian. ${ }^{1}$ It is rather a set of personal essays on various topics and themes in Nigerian writing as I have encountered it, following it rather unsystematically, over a little more than half a century, as part of a more general fascination with Africa's largest, very diverse country. My visits to Nigeria spread over four decades, although not over a more recent period. ${ }^{2}$ When I did not get there, I kept watching it from a distance. Yet, inevitably, this is the view of an expat-greeted as an oyinbo in some parts of the country, a bature in others (both meaning "Whiteman!").

At one time or other, I have visited much of Nigeria, from Lagos to Maiduguri-traveling by rental car, shared taxi, bus, rail, Armel's old combined goods/passenger trucks, or whatever. I had a look at the site of what was to become the new capital of Abuja before it was built; what had been old Abuja had just been renamed Suleija. Most of my time in the country, however, involved several stays in Kafanchan, a town that had developed around a railway junction close to the geographical center of the country, where I conducted field research as an anthropologist during several periods in the 1970s and 1980s. It shows up in various places in the book, but especially in chapter 14 . (From Kafanchan, too, various errands would take me now and then to the two nearest metropoles, Jos and Kaduna.)

\section{Townspeople's Horizons}

My studies in Kafanchan were planned to be primarily a project in urban anthropology, itself an emergent research field at a time when most anthropologists still chose villages for field sites. A natural focus 
was the relationship between ethnic diversity and the division of labor. The town was composed as a sort of Nigeria in miniature. ${ }^{3}$ It had considerable numbers of Hausa, Igbo, and Yoruba, Nigeria's three largest ethnic groups, but also many others of some twenty groups from near and far. There were only two long-term expatriate residents, an Irish priest at the Roman Catholic mission, and at the small hospital a Hungarian doctor in exile. (This was the time of the Cold War.) I saw little of either of them. But I met with railway workers, market traders, teachers, artisans, office workers, and others-once or twice even with the Emir of Jemaa, whose residence was in Kafanchan.

This all would have been basically a local study. I did that-but serendipity is part of field work, and things happened that made me shift my interests to a certain extent. Some of my new acquaintances among the townspeople saw me as a potential resource person, a gatekeeper to a wider world. One of them suggested that we go into the import-export business together-and as the Nigerian oil export economy was booming at the time, bringing about a certain modest affluence at least in some circles, he clearly had importing fairly sophisticated consumer goods in mind. Another suggested that I take this bright, promising young relative of his along when I left, and put him into my university overseas ... so he could then come back and become prosperous and powerful, an asset to his kinspeople. To begin with, I usually embarrassedly changed the subject, but gradually I realized that this was where at least some of the story was: this dusty town around the rail tracks was part of a wider world, in fact and in the townspeople's imagination.

Then I began to think, too, about the young urban popular culture. For one thing, the music I heard blaring from the loudspeakers of small record shops (this was still the time of vinyl records) was sometimes from elsewhere in the world-Jamaican reggae, North American televangelists, the soul music I had also heard in Black Washington where I had previously done field work-but in large part was a new West African popular music where traditional African songs and instruments met and mixed creatively with styles, technologies, and organizational forms from far away. Here were the sounds of highlife, juju, Afro-beat. And this came together with my readings of Nigerian fiction: Amos Tutuola, Cyprian Ekwensi, Chinua Achebe ....

This was a pioneer generation in modern Nigerian writing. Tutuola's writings went back to the depths of storytelling in his Yoruba culture (but did not only do that). Ekwensi's best-known early work depicted vibrant contemporary city life. Achebe's Things Fall Apart, still undoubtedly the most famous, widely read Nigerian novel, depicted the 
coming of colonialism to Igbo society. ${ }^{4}$ My engagement with Nigerian literature in this book starts here, in the writings of the 1950s and 1960s, also a period of transition from late colonialism to postcolonialism. Yet these and other writings could also look even further into the past, back to when there was yet no such entity as Nigeria in these West African lands.

\section{The Creativity of Global Connections}

By the time I got to Kafanchan, the tendency among academics and other intellectuals back in Europe and North America was fairly generally to assume that increasing global interconnectedness would necessarily involve homogenization, greater uniformity-a loss of a large part of the world's cultural diversity. That had been an ingredient in much modernization theory prevalent in the mid-twentieth-century social sciences, and it was still there but took on another form in radical critiques of "cultural imperialism" a couple of decades or so later.

But that was not what I saw. Cultural diversity was alive and well, although taking on some new forms. So I attempted to draw together descriptive materials of an emergent, vibrant West African town life, through observations and interviews. Yet I also wondered what might be an effective, coherent overall conceptualization of the longdistance cultural structures and processes I now found reaching into Kafanchan. At the time, the term "globalization" really had not yet entered the public vocabulary - as a keyword, it was hardly present before the 1990s. ${ }^{5}$ Yet when it appeared and spread, it turned out that it, too, could be taken to mean more uniformity, and that it tended to be used to emphasize market expansion, rather than to cover the wider range of forms of growing interconnectedness.

As I returned to my academic base and still thought about this, I learned that a few colleagues here and there in the world, who were also trying to make sense of the cultural orders and processes of their time, had found useful analogies in what linguists had been saying about Creole languages - and that attracted me, not least as I had had Creolist colleagues in the sociolinguistic project I had earlier worked with in Washington. ${ }^{6}$ Creole languages, occurring in various parts of the world, were mixed forms, with historical roots in two or more languages meeting in a contact situation. But they had developed into something more than limited contact languages. They had become complete languages, mother tongues for people who could conduct their entire speaking lives within them. And at the same time, they 
often remained in touch with the languages out of which they had grown-not least the standard, prestige form of some language based in one of the metropoles of the world. Creole languages bore the mark of the colonial situations of the past, and the postcolonial centerperiphery relationships that followed them into the present.

As with language, it could be argued, so to a considerable degree with culture. So I saw the lively cultural diversity of Kafanchan, in its openness to the world, in terms of a creolizing cultural process, which I felt had its parallels, with variations on the theme, in many parts of the world. ${ }^{7}$ This was obviously in contrast to that scenario of an inevitable, final global cultural uniformity, but it was also a move away from that old tradition in anthropology that had been inclined to see global cultural diversity as a sort of "global mosaic," where local societies and cultures were understood to have hard edges, clear boundaries.

As we were getting toward the end of the twentieth century, the interest in new culture emerging through cultural openness and mixture came to be reflected in a wider intellectual vocabulary of partly overlapping terms: apart from "creolization," they include "hybridity," "crossover," "fusion," "synergy." To a degree, they had their homes in different academic disciplines and involved different emphases. But they all did suggest that cultures had permeable boundaries, if they had boundaries at all; and again, openness did not result in the end of diversity.

The use of "creolization" and related terms comparatively, in many world contexts, has been debated-as often happens when a notion historically rooted in some particular region is turned into a traveling concept. Some would prefer not to take matters "Creole" out of the Caribbean, as others have objected to taking "caste" out of India. ${ }^{8}$ This matters less to us here.

Back, however, to the Kafanchan townspeople's imagination, which first provoked me to begin to think seriously about forms and implications of global interconnectedness. As I listened to, and participated in, casual conversations, and also as I reflected on the variety of Nigerian writings from all over, I found a preoccupation with the world outside-probably not among the mass of Nigerians who make their living more directly from the land, but among townspeople and city dwellers, and among people with more or less schooling experience.

Horizons fairly habitually stretched beyond city limits, beyond the country's borders. A central social type in mid-twentieth-century Nigerian English was the bintu, "been-to," the person who had been 
overseas (most often to the United Kingdom, which was, or had recently been, the colonial power) and had returned. In Kafanchan, real-life been-tos must have been very few and far between. I knew only one, a Yoruba petty entrepreneur who had had some technical training in Germany but was better known locally as a freelance street preacher for a revivalist Christian group. Yet in the collective imagination they were well represented. They showed up in Nigerian fiction, too-chapter 7 offers examples. If the been-to was somewhere fairly close to the metropolitan end of a Creole cultural continuum, at its other end was the derogatory epithet "bush," used to label what was unsophisticated, uncouth. Yet there could be some ambivalence here, since it was also possible in some moments to show certain nostalgic sentiments for the innocence of old-style village life.

Soon enough, with the beginnings of serious Nigerian media research, I would also learn that while the American Dallas series was soon everywhere, the most popular sitcom series were those produced locally. ${ }^{9}$ (This was already in the days before Nollywood, the now flourishing Nigerian film industry.) And much of the earthy humor of these series was generated in depictions of local responses to metropolitan influences. Often enough they showed people making fools of themselves as they embraced alien cultural items, and made inept use of them. In the Masquerade series at one point, a local chief, invited to try a new dish, stared at the spaghetti and asked what were the worms on his plate.

\section{Nigeria and the World, in Time}

By 2020, the cover story of a U.S. newsweekly could forecast that Nigeria was "The World's Next Superpower" (Hill 2020). In various ways, the country increasingly draws global attention. But for a much longer time, it has been Nigeria - or at least many Nigerians, or people in the past whom we would now see as the ancestors of present-day Nigerians-that has appeared preoccupied with the connections between it and the outside world. Presumably this has to do with the way Nigeria came into being as a country. As a geopolitical entity it moved with time from the assortment of arbitrary territorial constructs of nineteenth-century colonialism, with European empires competing with each other, to the kind of globally standardized state format of the post-World War II, United Nations era. ${ }^{10}$ And the founding father of the country was really more of a stepfather: Frederick Lugard, eventually Lord Lugard, first governor of a united colonial Nigeria. The 
very name "Nigeria" was proposed by his wife, Flora Shaw, colonial correspondent of the Times of London.

Lugardhadhadazigzag (butupward) careerin the service of theBritish Empire-through Uganda, Burma, and Hong Kong-so he developed a sense of colonial management, which he could use in Nigeria. ${ }^{11}$ This was a huge territory, with an almost entirely indigenous population, and it required a low-cost form of imperialism. Consequently, Lugard adopted the principle of "indirect rule," which may have been inspired by India, where the British had in fairly large part left maharajas and other old-style rulers to run many things in their established ways. In Nigeria it would mean identifying, and sometimes inventing, "native authorities," and outsourcing local government to them, under the supervision of what was often a quite sparsely distributed corps of district officers. ${ }^{12}$ This, for one thing, helped maintain into Nigerian independence a striking internal diversity, which probably made more difficult those typical steps toward shaping a national public culture, with shared symbolic forms, taken more effortlessly in a smaller, more homogeneous new state.

Naming could be part of such nation-building. Ex-French Soudan became Mali, ex-British Gold Coast became Ghana, ex-Nyasaland became Malawi, the ex-Rhodesias became Zambia and Zimbabwe. Nigeria remained what Flora Shaw named it. While Salisbury became Harare, Santa Isabel became Malabo, Lourenco Marques became Maputo, Leopoldville became Kinshasa, Fort Lamy became Ndjamena, and Bathurst became Banjul, one of Nigeria's major cities is still Port Harcourt—named by Lugard after Lewis Vernon Harcourt, sometime secretary of state for the colonies. The name Lagos, of course, comes from the Portuguese.

Sports have tended to be a domain where nationalism flowers, even in countries where it may by now otherwise often be frowned on. Team sports as a kind of collective manifestation are particularly prominent here. ${ }^{13}$ To a degree, this works in Nigeria as well. The pride over the success of the national team the Super Eagles, football (soccer) gold medalists in the Olympic Games of 1994 in Atlanta, was manifest. Yet even here the imagination of Nigerians is likely to turn outward: personal success is shown in footballers' migrations to Manchester United or Arsenal. ${ }^{14}$ The parlor walls of one of my best friends in Kafanchan, a successful local footballer, were covered with pictures of teams in the British Premier League.

In an upsurge of academic interest in nationalism in the 1980s, the historian Benedict Anderson (1983: 15-16)—with his own wideranging life story between Hong Kong, Britain, Ireland, Indonesia, and 
upstate New York academia, but apparently without significant African landings-launched the notion of nations as "imagined communities." Nations, he proposed, are "imagined," as members would never know most compatriots personally. Yet they are "communities" because they are conceived as involving a deep, horizontal comradeship. They are "limited" because they have finite, if elastic, boundaries, with other nations lying beyond these. And it is also a part of the imagination that they are "sovereign."

We may sense that Nigeria, in its history, has not matched these criteria particularly well. Centrifugal sociocultural forces were built into the construction of Nigeria. Boundaries have been arbitrary and weak on the ground; the imagination has often carried citizens yet further away; that deep comradeship has hardly been a strong widespread sentiment; sovereignty may have been celebrated, but only after the entity in question was created as part of an alien empire. Perhaps the nearest thing to a nation in an Andersonian sense, within what is now Nigerian territory, was for a short period Biafra, homeland of the Igbo. Or even more briefly, in 1966, the North, in turmoil after a first Southern-led military coup, with its battle cry of "Araba!" (secession). Some of the fiction portraying this period in all its complexity is discussed in chapter 15.

Instead of remaining within national boundaries, then, the real homeland of the imagination has thus been stretched out along that transcontinental cultural continuum. And this is not the land only of compatriots taken to be more or less like oneself, but a habitat that also includes more or less problematic Others: expatriates as well as people to whom one is oneself some kind of alien. The preoccupation with the outside could seem a bit surprising: usually it is larger countries that can best afford to turn mostly inward, and Nigeria is a large country.

Pan-Africanism, of the early variety linked not least to Kwame Nkrumah, also had great difficulty turning itself into a credible continent-wide alternative, in lands that continued to be divided between, not least, a Francophonie and an Anglophone Commonwealth. Whatever has been said in public oratory, these entities seemed to be enduring facts on the ground, in politics as well as in literature and popular culture. In Nigeria, moreover, there was always some sense of embarrassment that Nkrumah's Ghana had made it into independence, out of the same empire, before its larger, more important neighbor a little distance away. In his late volume of autobiographical reminiscences, The Education of a British-Protected Child, Chinua Achebe (2009: 41) comments on the way this was dealt with, intellectually and politically: "True, Ghana had beaten us to it by three years, but then Ghana was 
a tiny affair, compared to the huge lumbering giant called Nigeria. We did not have to be vociferous like Ghana; just our presence was enough."

There is, of course, also the language factor. Nigerians speak hundreds of languages, most of them rather local. The national language is English, but as such, it is also British (and American, Canadian, Australian and so forth), as well as the dominant world language. It cannot serve as a distinctive national marker. Hausa, Igbo, and Yoruba are spoken and understood by a great many people. But if you know one of these, it is less likely that you know another so well. Consequently, such literature as exists in these languages becomes regional, rather than national. ${ }^{15}$ (The same is true with regard to print news media.) For books, written and published in a national language that is also a world language, however, that keeps raising the question who they are actually for. ${ }^{16}$

\section{The Afropolitans}

Then in the twenty-first century come the Afropolitans. The term was evidently set in real motion through an essay named "Bye-Bye, Babar" by Taiye Selasi, herself born in London to a Ghanaian father and a Nigerian mother, and raised in Massachusetts, with university degrees from Yale and Oxford, launching her literary career with the novel Ghana Must Go (2013). The opening scene in the essay is from a London bar. The disc jockey spins a Fela Kuti remix. The whole scene, writes Selasi, "speaks of the cultural hybrid." The people present are beautiful brown-skinned people, multilingual, people from law firms, street fairs, chem labs, art shows. These are Selasi's Afropolitans, either born in Africa (anywhere on the continent, not necessarily Nigeria or West Africa) or the children of African transnational migrants. "They belong to no single geography but feel at home in many." ${ }^{17}$ Even before that, however, "Afropolitanism" had been the title of an essay by the historian Achille Mbembe-born in Cameroun, with an academic career taking him through Europe and the United States to South Africa. Mbembe's (2007) essay was locally published by a Johannesburg art gallery, and not so easily accessible. Yet he rooted his new concept more deeply in the extended past of the continent, pointing to both its internal openness and flux and its openness to the world. ${ }^{18}$

Selasi's twentieth-century Afropolitans are people with personal success stories, in large part away from Africa, but Africa means something to them, and it is not just poverty, wars, or disasters. They 
are engaged in creating other Africas, and other connections between Africa and the world. For one thing, they are prominent in writing: apart from Selasi herself, Chimamanda Ngozi Adichie and Teju Cole (to mention two with Nigerian roots) are clearly among them. Adichie's bestseller Americanah (2013) is a study in Afropolitanism. We get to it in chapter 17.

Yet about the notion of Afropolitanism there has already been some controversy. I am not surprised-the notion of "palaver" has deep historical roots in West Africa. How long the term will be a part of the current vocabulary perhaps remains to be seen. In Taiye Selasi's original version, there may have been an elitist streak. Partly for that reason, it has been suggested that it should be used in the plural, as "Afropolitanisms," to signal that there are many kinds; that, of course, has also been argued for "cosmopolitanisms," in another, related, debate. ${ }^{19}$

Anyhow, I would suggest that the term is now in the domain of intellectual commons, and I will take a certain liberty with it here. Rather than engaging with ongoing debates over Afropolitanism in its current forms, mostly among literary scholars, I will use it as a term with extended time depth, more in line with Achille Mbembe's original discussion: to sum up, with a convenient single word, involvements of West Africa with the outside world, past and present. These are involvements going back to the horrors of the seventeenth century transatlantic slave trade, and then passing through many phases into the twenty-first century. Looking eastward, there has been the wish of Muslims to make the pilgrimage to Mecca. In a way, this part of Africa was Afropolitan before it became Nigeria.

Again, for Selasi and many commentators, the Afropolitans may be people of today's world. They are in it at a time when the New Yam Festival is celebrated not only in Igboland, where Chinua Achebe described it in Things Fall Apart, but in Birmingham, England, as well as in New York and New Orleans. Yet this generation seems to me to be conceptually the descendants (children or grandchildren) of the been-tos: more sophisticated than these forerunners, a jet set not so inclined to be permanently returnees, but moving back and forth between continents. ${ }^{20}$ Nevertheless, they continue to be a part of the long-term engagement with the world, along that historical continuum of creolization and hybridity.

With that longitudinal view, I think one can also discern a certain shift in centers of gravity. With the early been-tos there is a quite strong sense of the rather durable soft power of colonialism. Selasi still places her bar scene in London, and Bernardine Evaristo, winner of the 2019 
Booker Prize with her lively but mostly London-based Girl, Woman, Other, is identified as "Anglo-Nigerian." Over time, nevertheless, I think there has been a drift on the -politan end of the continuum, from Britain to the United States. Already in 1947, speaking at New York City Hall, one of the pioneers in this change could reminisce about early practices: "Twenty years ago, whenever I visited New York City on a short trip from my university, and found it uneconomic to seek for a house to pass the night, I learned from experience how to pass a comfortable night in the subways, so generously placed at the disposal of guests and residents of the city, for the nominal charge of a nickel!" This was Nnamdi Azikiwe, later to become Nigeria's first president. $^{21}$

The engagements of Nigerians with America (and to a degree Americans with Nigeria) are discussed particularly in chapters 16, 17, and 19. But there is certainly some variety in transcontinental linkages. In times of coups and military regimes, the Royal Military Academy at Sandhurst, southwest of London, was also an important place in this Afropolitan landscape because of the training it had given Nigerian officers. Moreover, those soccer stars could probably be Afropolitans, too. Not to speak of the members of the Nigerian women's bobsled team in the 2018 Winter Olympics in Pyeongchang, South Koreathey were from Houston and Dallas, Texas, and St. Paul, Minnesota. ${ }^{22}$

Then, with regard to the latest generation of Nigerians and other West Africans moving around across borders, one should keep in mind the fact that theirs are not all stories of successful careers, between New York and London on one side and Lagos and Accra on the other. They are also among the struggling traders between the markets of Guangzhou in China and Onitsha on the River Niger. ${ }^{23}$ They are among the young Southern Nigerian women recruited by criminal networks to work the streets of Europe. ${ }^{24}$ And they are among the boat refugees trying to make it from Africa to Europe on unsafe vessels across the Mediterranean. ${ }^{25}$

Even beyond that, however, I will let my notion of "Afropolitan horizons" extend as far as to moments when no physical border-crossing is actually involved, but when the imagination somehow takes in aliens, and the outside world-in later chapters, when the peers of an aging Hausa woman at the mid-twentieth century warn her that the foreigners may fly her away out of Kano Airport; or when, in the midst of a civil war, the sympathies of distant countries are made to matter, and a white priest turns out to be a foreign mercenary.

Clearly Nigerian writing has not been evenly distributed over the country, in terms of the background of writers, or in terms of topics 
and scenes. There has been a continuous preoccupation with Lagos as a difficult, yet oddly attractive place-in no small part due to its openness to the world, one of the home towns of Afropolitans. In this book, the Lagos focus is represented particularly in chapters 5 and 9. But in chapter 6 I also try to map some other significant Southern Nigerian sites of literary history, and chapters 12 and 13 offer at least glimpses of Northern Nigeria. Then chapter 18 follows two Afropolitan travelers on their return journeys through the entire country. Continuously, it is an important point that even as you go inland, outside connections keep appearing, keep being handled.

Before that, chapters 16 and 17 are about Nigerians' encounters with the United States. And then in chapter 19 the gaze is reversed, as Black Americans engage with a West African heritage, retrieved or reinvented.

\section{Literary Anthropology: Studying Sideways}

Reviewing the social anthropology of West Africa in 1985, Keith Hart (who had himself done early urban ethnography in Nima, a ramshackle suburb of Accra) noted some of the weaknesses of description in academic writing, and went on to point out that

in the 1960s a dazzling creative literature arose which ought to be seen as part of the region's anthropology .... No social anthropologist set out to emulate Turgenev; but the West African novel brought a whole new perspective to our understanding of what makes the region's peoples unique. Perhaps in time something of that distinctive voice will rub off on our ethnographic literature. (Hart 1985: 254-255) ${ }^{26}$

It so happened that just after Hart wrote, anthropologists (not only West Africanists) indeed started to pay more attention to how they wrote. In a very multifaceted development over the time since then, something now referred to as "literary anthropology" has become a lively part of the discipline. ${ }^{27}$ It takes varied forms: turning ethnography into something less like conventional academic styles, more like creative nonfiction; autoethnography, placing the anthropologist's own life story in a wider context; reflexive field work accounts, portraying the personal experience of immersion in a field; and other kinds-but also the anthropological study of literature itself, as finished texts as well as a kind of life and work, set in its social context. ${ }^{28}$ Frequently this involves drawing on field research in inspecting and commenting on literary work. 
This is what I attempt to do in the chapters that follow. It is a memoir of one reader's encounters with writings, and occasionally and briefly with writers as well-not very respectful of the boundaries of established genres and disciplines. I am a fan of Nigerian writing, but a stranger to the conventions of literary scholarship. I am in a continuous back-and-forth movement between texts and what I know in other ways, from personal experience and from field study. What follows is not a study of Kafanchan, but a set of essays where this town appears here and there as a point of departure for further commentary. It also means that I approach texts as an anthropologist-not as a literary theorist or reviewer, who may be looking for other things and making other kinds of judgment. For one thing, people can appear in fiction as members of their classes or ethnic groups, but beyond that as multifaceted personalities. Not everybody in real life will have as dramatic and complicated experiences as Cyprian Ekwensi's Jagua Nana or Okey Ndibe's Ikechukwu, yet the scenes through which they pass draw on recognizably Nigerian localities and passages.

I would expect most of my readers to be outside Nigeria, without much prior local knowledge: socially, culturally, politically, historically, geographically. But I would certainly be happy to have some Nigerian readers as well. The Nigerian literary and scholarly scene is welldeveloped and internally lively, and it is natural that most cultural commentators will do their observing and reflecting where they are at home. ${ }^{29}$ Yet from the stance of transnational openness, which is a theme of the book, I hope there is also room for some interested outsiders like me.

My focus is on Nigerian writers over approximately a seventy-year period, from the late colonial 1950s to the present. Mostly they are fiction writers-although as public intellectuals, some of these have also discussed Nigerian society in nonfiction texts. Chinua Achebe and Wole Soyinka are obvious examples. A handful of these writers, including the two just mentioned, have come to be included in an emergent Nigerian literary canon, in terms of literary quality and public attention, and have drawn a very large part of the academic and critical commentary on Nigerian literature. My objective is not so much to contribute to that sort of study, with a focus on those same authors and their main works, although they do show up in what follows as well. I drop in here and there in the entire landscape of writing, rather, to assemble a view of Nigerian life and the Nigerian imagination.

It is another aspect of my kind of literary anthropology that it moves, at times, between fiction and other kinds of writing. Moreover, it draws on a border-crossing combination of insider and outsider 
writings: in this case, Nigerian fiction (and some other Nigerian social commentary) on the one hand, and certain writings by expatriate colonial officials, journalists, and fiction writers with their long-term bases elsewhere, as well as anthropologists, on the other; see not least chapters $2,3,4,8$, and 12 . I see them as throwing light on each other, even as literary scholars mostly do not engage with the latter types of writings. Taken together, this becomes a network of perspectives toward Nigerian life as it has shifted over time: approximately from Charles Dickens's imagined Borrioboola-Gha (in chapter 4) to Chimamanda Ngozi Adichie, Teju Cole, and beyond.

This approach also relates to a certain debate largely elsewhere in anthropology's past. In a classic essay of academic rethinking, Laura Nader (1972) argued that anthropologists had mostly engaged in studying people less powerful and prosperous than themselves-that is, studying down - and now the time had come to study up. (Colonial anthropology, obviously, had tended to be studying down, inspecting "the natives.") Nader's proposal drew much sympathy. Yet perhaps in the long run, the actual outcome has not been so impressive. For one thing, anthropologists like to study groups they can sympathize with, and they are often not so sure they will do that when studying up. For another, there is a question of access. Powerful people can more easily close their doors: "Dogs and Ethnographers Not Allowed."

As for myself, I have been inclined to study sideways: taking an interest in other groups of people involved in knowledge productionin large part transnationally, although perhaps with different interests, under other constraints. Frequently these are people whom anthropologists are for one reason or other irritated with, in whose work they are inclined to find faults. Perhaps they are often right in this, but it may also be useful to approach such groups as field-working anthropologists usually expect to do, with a fair amount of respect and willingness to learn. In a way, looking back, I would see that as a part of my general stance toward anthropology. No discipline is an island, or it shouldn't be.

Along such lines, I have studied sideways among news media foreign correspondents (more about this in chapter 8), and I have scrutinized the texts of writers producing global future scenarios, and the reception of these texts. ${ }^{30}$ I see my interest in writings from and about Nigeria, by novelists and other non-anthropologists, in the same light.

Again, literary anthropology tends to involve a certain blurring of conventional genre boundaries. Such blurring, too, may keep showing up in unexpected ways. A decade before Keith Hart's comments on West African anthropology, in 1974, the journal Africa offered an 
article on "Social Anthropology in Nigeria during the Colonial Period," a retrospective account by G. I. Jones, former district officer turned anthropologist. (This journal was the organ of the International Africa Institute, an organization launched by Frederick Lugard after he returned from Nigeria to Britain.) Jones's article can still offer irritations, amusements, and insights, but this paragraph is relevant to the perspective of the present book:

To the average Ibo villager, an anthropologist is someone who knows more about Ibo traditional culture than he does himself. Any monograph written by an anthropologist on a particular tribe and accessible to its literate members becomes the tribal Bible, the charter of its traditional history and culture .... Today it is the novelists and playwrights who describe the culture and institutions and the historians who try to record the oral tradition, and it is in this field that anthropology has most to answer for, since the oral tradition of many of these Southern Nigerian communities has completely absorbed, and been corrupted by, the myths of the anthropologists. (Jones 1974: 287)

Jones and Hart were both anthropologists with Cambridge connections, to a university department with a high profile in West African studies. But if there is only that decade between their respective comments, there is more like an academic generation between them-and they seem to point in opposite directions. Hart suggests that anthropologists should be inspired by those novelists, while Jones portrays the Nigerian novelists and playwrights as dependent on the early expatriate anthropologists. ${ }^{31}$

One may suspect that Jones exaggerates a bit, yet his view could stimulate our curiosity about just how those more or less Afropolitan writers, from Ben Okri to Chigozie Obioma and beyond, come by their understandings of indigenous Nigerian thought worlds, and how much of such understandings in their writings is importantly shaped by their own creativity. Did they learn about such matters at the dinner table, from their usually well-educated parents? Or in the visits to home villages, during the long holidays? Or did they indeed read about them?

Our curiosity here may be intensified by the fact that a number of recent writers of Nigerian background have moved on from the social realism of the early postcolonial generation of novelists to something more like a magical realism, where transnational migrants of flesh and blood mingle with somewhat amorphous spirits. ${ }^{32}$

There is an interesting instance here in Chigozie Ogioma's novel $A n$ Orchestra of Minorities (2019), very well received by critics, with the central figure migrating from his small hometown setting in Nigerian Igboland to Cyprus, and then back-remarkably with that central 
figure's guardian spirit as narrator. Chigozie Ogioma himself is an Afropolitan of today's version, currently teaching creative writing at the University of Nebraska-Lincoln. He grew up in Nigeria, although not actually in the homelands of his ethnic group. We come back to him briefly in chapter 18. In an "author's note" on sources at the end of his novel, Obioma (2019: 445-446) acknowledges the early influence of his mother in discussing the Igbo spiritual world, and notes that he also drew on his father's and his own local field research in Igboland, and on several Nigerian written sources, including writings by Chinua Achebe. ${ }^{33}$ But then, he points out, he was able to also use an early anthropological report on the Igbo, published in 1913-14 by the British anthropologist Northcote W. Thomas. We can learn from one historian of anthropology that the British colonial administration at the time regarded that same Thomas as a difficult and eccentric figure (Mills 2008: 51). As people inserting themselves in social space between the locals and the expatriate representatives of the empire, some number of field-working anthropologists those days experienced something like that.

This may be the point to say something about the state of anthropology at that later time, when G. I. Jones wrote about its influence on Nigerian literature. It was in a period when the relationship between anthropology and Nigeria, and much of Africa, was not so great. Historically, anthropology as a scholarly discipline had developed most strongly in countries with overseas empires-Great Britain, France, the Netherlands, Belgium-and in a period of postcolonialism, it could seem tainted by such imperial connections. ${ }^{34}$ The new African universities tended to establish departments of sociology, regarded as a more modern discipline, and anthropologists adapted at this stage by discreetly finding their homes in these. Meanwhile, in Britain and elsewhere, the imperial past became for some time a preoccupation of postcolonial anthropology, perhaps with overtones of an ivory tower intergenerational conflict. ${ }^{35}$ At the same time, it may be worth noting, as some Nigerian students found that anthropology could be a discipline to their liking, they crossed the Atlantic to be trained in the United States. (We come to one example in chapter 3.)

\section{Reading Nigeria: The Bookstores}

During my research periods in Kafanchan, I would usually stay at the Rosy Guest Inn. It was a small, one-story building under a zinc roof, with a courtyard in the middle and rooms around it-very ordinary 
small-town Nigerian architecture. As it turned out, the Nigerian Army, never fully demobilizing after the Biafra War, had placed something like a battalion in Kafanchan, and consequently its officers took over much of the available, more desirable accommodation. So Rosy Guest Inn became the solution to my housing problem.

It also became one of my entry points to town life. While I remained for an extended period, most of the guests came for overnight stays or short periods: ginger traders, witchcraft and sorcery experts, soldiers who just wanted to escape from boredom for a day or night of feasting. My small typewriter was the only one in the house (this was before the era of laptop computers), so I would occasionally help by typing out a new copy of the dining room menu.

I also got to know the proprietor. The owner of Rosy Guest Inn was a hard-working entrepreneur from the south of the country. He was only part-time in Kafanchan, as he also ran another Rosy Guest Inn in Kaduna, some two hundred kilometers away, where he had his family. So he would be moving between these establishments regularly on a rickety old motorcycle. Later on, he established yet another Rosy Guest Inn in Zaria. (It was staying there once, briefly, that I learned from my transistor radio of Ronald Reagan's election to the U.S. presidency.)

But that was not all. In Kafanchan as well as Kaduna, he ran book and stationery stores, under the name of Nakowa Bookshop. I would go to Nakowa daily, at least for my copy of the New Nigerian, the leading newspaper of Northern Nigeria. I could get the major national newspaper, the Daily Times, there as well, and the weekly Lagos Weekend (purveyor of capital city gossip and scandal), and other weekly and monthly magazines more haphazardly. The assortment of books was actually limited. I learned from my friend the owner that most of his book business involved contracts for textbooks with local schools. There was also some competition with another small bookshop, a holein-the-wall establishment run by a man who had learned something about the trade working in a mission bookstore in a larger town.

Part of my encounter with Nigerian writing thus came from these stores in Kafanchan: some books from the few Nigerian publishers, some imports-mostly of Heinemann's African Writers Series, which had a pioneer role in offering outlets for writers from many parts of the continent, or from the less acclaimed Fontana Books, publishing the mostly rather short novels of a certain set of other authors. ${ }^{36}$

Kafanchan, then, also provided an important context for my engagement with Nigerian writing. Browsing in bookstores is really part of field work in literary anthropology. Some bookstores here and there in the world become famous and get books written about 
them. For me, Nakowa deserves at least these few lines. Early visits to Lagos would then take me to the CMS Bookshop, in Broad Street. The acronym stands for Church Missionary Society-but though it was an Anglican mission enterprise, it had a rather wide assortment.

Visiting Nigerian bookstores, it is true, hopeful readers might not always have found much chance of browsing. Okey Ndibe (2016:118), whose writing career would later take him to the United States, and the pleasure of finding bookstores there equipped with couches and coffee counters, would reminisce that, in the late 1980s in Nigeria, "few, if any, bookstores would allow a wandering customer to thumb through the pages for more than a few seconds. Books belonged on shelves."

Keeping somewhat in touch with West African culture and literature, however, has not always required traveling to West Africa. For a very long time, I subscribed to the weekly West Africa, somewhat officious, now defunct, but then published in London from an address near Fleet Street. ${ }^{37}$ In the 1960s and 1970s, going to London regularly, I would find much available in the better bookstores: Foyles certainly (a multistory establishment, which in its apparent unconcern with turnover could exhibit the same books, and very likely the same copies of sometimes obscure titles, on its shelves year after year), but further down on Charing Cross Road, Collet's was the bookstore of leftist politics, which also meant that it was strong on the Third World and its remaining independence movements. ${ }^{38}$ In Great Russell Street, opposite the British Museum, there was Kegan Paul, Trench \& Trubner, fairly old-fashioned "Oriental and African" booksellers. Dillon's in Bloomsbury was in an academic neighborhood and carried scholarly literature as well as a wide range of fiction. At one point or other there would also appear some small bookshop, more specialized, probably in an outer borough, and catering above all to a reading public among the Black British. Writing aside, one could go Stern's Radio at the upper end of Tottenham Court Road for records of West African music: highlife or whatever.

Elsewhere, there were other establishments to which I would return when opportunities arose. In New York's Greenwich Village, the University Place Bookshop was strong on African studies; in Paris there was the Presence Africaine store in Rue des Écoles (focusing on the Francophonie, connecting more to Dakar than to Lagos).

As Nigerian writers have entered world literature, now one need no longer look for their works only in specialized establishments. Go into a good bookstore almost anywhere, look for the alphabetized shelf for international fiction, and almost immediately you may see "Achebe, Chinua," and then "Adichie, Chimamanda Ngozi." 
Of course, the assortment of bookstores has changed over time. Some have closed; others have shifted form almost beyond recognition. Furthermore, there have been signs of change in the more or less transnational publishing industry. For a long time, it was an unhappy circumstance that the books of writers who found publishers abroad (again, being in English) and drew the interest of the outside world could be out of reach for most Nigerian readers. They were too expensive, or simply not locally available. The writers who published at home, on the other hand, were invisible elsewhere.

Now all that seems to be changing. By 2017, a Weekend Arts section of the New York Times could carry a headline proclaiming "Nigeria's Literary New Wave." The article identifies a new set of writersAbubakar Adam Ibrahim, Ladipo Manyika, Leye Adenle, Ayobami Adebayo, and Elnathan John, all evidently more or less Afropolitan. The publishing scene is also changing. Faber and Faber in London has been there all along, presenting Nigerian writers from Amos Tutuola to Teju Cole. But the New York Times article points to the important role of Cassava Republic Press, remarkably based in Abuja, in trying to fill the gap between local and international publishing (Alter 2017). At much the same time, on the other hand, an American academic press could offer a monograph by Adélekè Adéèkó (2017), professor of African Studies and English at Ohio State University, which concludes that the current style of Nigerian book launch events, often involving more or less ghostwritten autobiographies by eminent individuals and published sometimes as vanity press ventures, has come to draw significantly on an established but protean tradition of rites of passage: speech-making, donations, praise singers, and more. So all that may now be another part of that same open but ever-changing Afropolitan, creolizing continuum of cultural diffusion and creativity that, again with some back-and-forth movement, stretches between New York, London, Lagos, and Kafanchan.

\section{Notes}

1. It is true that some of the major contributions so far have been by other expatriates, such as Griswold (2000), Newell (2006) and Lindfors (e.g., 2010). I am well aware that I say little or nothing about some important, in certain cases very productive, writers: S. A. Aluko, Gabriel Okara, Ben Okri, Chris Abani, Festus Iyayi . . . . In particular, I know that there is not much in these pages about some women writers, such as Flora Nwapa, Buchi Emecheta, or, more recently, Ayobami Adebayo or Bernardine Evaristo. Other commentators will be better equipped than I am to deal 
with them. See, for example, Paula Uimonen's (2020) lively study of the life, work, and lasting influence of Flora Nwapa. I say hardly anything about children's literature, although some of Nigeria's best-known writers have contributed to this field as well-probably because such texts have been used extensively in schools. Moreover, I deal only with prose writings, and not at all with drama, although that would include important early writings by Wole Soyinka, John Pepper Clark, and Obi Egbuna. Finally, while these essays stretch over a considerable time period, they do not take into account a development that may become increasingly important in the future of writing and publishing: the digital media (see, e.g., Uimonen 2019).

2. For a wider retrospective view of my life as an anthropologist, including my Nigerian experience, see Hannerz 2019.

3. I portray Kafanchan briefly, with some emphasis on matters of literacy and media use, in my book Cultural Complexity (Hannerz 1992: 22-26), and, by way of introduction, in Transnational Connections (Hannerz 1996: 1-2). For more detailed discussions of my field research methods there, see Hannerz 1976 and 1982; for some comments on Kafanchan in the context of center-periphery relationships and creolization, see Hannerz 1989; and for a retrospective view of my field study and the turn to studying transnational linkages, see Hannerz 2022.

4. During much of the period I am involved with, the more common spelling was "Ibo," but as "Igbo" is now the more common form, I use that throughout (except in quotes when "Ibo" is used in the original).

5. I dwell on the uses of the terms "globalization" and "transnational" at greater length in my book Transnational Connections (Hannerz 1996).

6. For my earlier discussions of creolization concepts, see especially Hannerz 1987 and 1996: 65-78. The early article by Fabian (1978) on African popular culture influenced me especially. My linguist colleagues in Washington had been impressed not least by the work of Lorenzo Dow Turner, discussed in chapter 19.

7. For a view of the debate over the uses of creolization concepts, see the volume edited by Charles Stewart (2007). See also the comparative study of creolizations, drawing on materials from many places, by Cohen and Sheringham (2016). On the uses of creolization ideas for political theory, see Gordon 2014.

8. As a traveling concept, moving out from its region of origin to a wider use for comparative purposes, "caste" has arrived in Nigeria, too, applying to the osu category of shrine servants in traditional Igbo religion: note the case of Clara, a young woman of osu background, as depicted by Chinua Achebe in No Longer at Ease, in chapter 7. There are references to the osu in Things Fall Apart as well.

9. On early Nigerian television comedy, see, e.g., Oreh 1985.

10. On the global standardization of mid-twentieth-century states, see Meyer 1999.

11. For an extensive biography of nearly half a century of Lugard's life, with a wealth of information of his Nigerian activities and experiences, see Perham 1960. 
12. Murray Last (1970) offers an illuminating review of four historical phases of administration and dissent in Hausaland, from the precolonial through the colonial period into early Nigerian independence. For a critical and comparative analysis of indirect rule and related forms of colonial government in Africa, see Mahmood Mamdani's Citizen and Subject (1996) - by a prominent political scientist whose transnational academic career has stretched between Makerere University in Kampala and Columbia University in New York. Mamdani describes indirect rule of the colonial Nigerian type as "decentralized despotism." See also the view of indirect rule in Nigeria and its later consequences by a Ghanaian (later Canada-based) observer, Ato Quayson (1994).

13. On this, see Gingrich and Hannerz 2017: 17-18.

14. According to one interview, Aliko Dangote-with a family background in groundnut and kola nut trade, later with what amounted to a national monopoly in cement production, recently apparently the hundredth richest person in the world-has hoped to buy Arsenal, the London football club, his favorite team (Pilling 2018).

15. I will not engage with literature in other languages than English here (with the one exception of discussing one Swedish-language book in chapter 1). Probably the best-known examples of Nigerian non-English literature are the mid-twentieth-century writings in Yoruba of Chief Daniel Olorunfemi Fagunwa, a source of inspiration for, among others, Amos Tutuola (see Lindfors 2010: 65-74). It is true, too, that some of the early Onitsha pamphleteering-see chapter 6-was in Igbo. On attempts to stimulate writing in Hausa from the late colonial period onward, see Furniss 2006. In a later period, particularly in the 1980s, a "Hausa Literary Movement" developed; on the links between that, radio broadcasts, and the home video industry, see Adamu 2002. At least in part this overlaps with what has been described as "Kano Market Literature," a soyayya genre of popular romance, seen by some as a counterpart of the Onitsha publishing industry. As far as print news media in regional Nigerian languages are concerned, the Hausa-language newspaper, Gaskiya ta $\mathrm{fi}$ Kwabo, may have been the best known.

16. The question whether African novels in world languages have to be seen as "extroverted" was raised by Eileen Julien (2006); about a decade later, Nathan Suhr-Sytsma (2018) has concluded that they can now be seen as on the whole neither inward-turning nor outward-turning, but as "multifocal." This also has to do with an increasingly multilocal publishing industry.

17. Shifting to elsewhere in the conceptual landscape, we could sense that some of these Afropolitans are what have been somewhat dubiously called "third culture kids," children raised not wholly in their parents' culture of origin, and not really in the local culture of the place where they find themselves, but rather in some hybrid of the two. They tend to be products of reasonably comfortable expatriate childhoods. While the term has become popular, it is theoretically somewhat antiquated.

18. In later writings, Achille Mbembe has also connected his notion of Afropolitanism more to earlier Francophone writers and to diaspora 
concepts. While several of these publications are in French, the early (2007) essay remains the most often cited, and has also been republished as Mbembe 2020, thus rendered more accessible.

19. In one illuminating later discussion, Eze (2014: 240) has suggested that an Afropolitan is "that human being on the African continent or of African descent who has realized that her identity can no longer be explained in purist, essentialist, and oppositional terms or by reference only to Africa." For more on the debate, see Ede 2016, Gehrmann 2016, and a thematic issue of the European Journal of English Studies (Durán-Almarza, Kabir, and González 2017). A recent user of the concept is Harris (2020), who sticks to a more specifically literary understanding and focuses on South African writing. In anthropology, Ryan Skinner (2015) has promoted a concept of Afropolitanism in his study of popular music in Mali, Bamako Sounds-without mentioning Taiye Selasi, and drawing more on Achille Mbembe's writings.

A related term, “Afropean," appeared already in the early 1990s, according to Black British writer Johny Pitts (2019: 1), who uses it to cover his reporting on Black Europe.

I have discussed the varieties of cosmopolitanisms elsewhere (Hannerz 2004a; 2016: 170-176). Eze, in the paper referred to above, draws partly on my view.

20. I note that James Hodapp (2016), writing about the early 1990s novel Yoruba Girl Dancing by Simi Bedford as a "proto-Afropolitan Bildungsroman," also makes the historical connection between been-tos and Afropolitans.

21. This is from a collection of Azikiwe's (1961) speeches. "Zik" attended several of the historically Black academic institutions for periods of varied length, but he was mostly at Lincoln University, Pennsylvania-from which, a little later on, Kwame Nkrumah would also graduate.

From about the same time as this New York speech by Azikiwe is the book Without Bitterness (1944) by Nwafor Orizu, Igbo of aristocratic origin, student in the United States, and an ardent follower of Azikiwe. Published in the United States as World War II was coming to an end, it is rather gently anticolonialist, pro-American, and critical of the British in a tone that goes with the title of the book. Orizu returned to Nigeria and had a prominent part in politics between the achievement of independence and the first military coup, but was otherwise most active in education.

22. On this, see the report in the New York Times (Rich and Akinwotu 2018).

23. On African traders in China, see Mathews, Lin, and Yang 2017.

24. On the recent transnational Nigerian sex trade, see Ellis 2016: 180-187 and the report by the journalist Ben Taub (2017) for the New Yorker.

25. See Andersson 2014 on the passage from West Africa to Europe, especially by way of the Spanish enclaves of Ceuta and Melilla. For a brief study exemplifying the spread of Nigerians in Europe, under differing circumstances, see Andrikopoulos 2013 on communities in the Netherlands and Greece. DeWitte (2019), touching in passing on the "Afropolitan" concept, offers an interesting view of the establishment of an African identity in the Netherlands, although most of the West African migrants there are from Ghana rather than Nigeria. Their encounters there with 
the longer-settled Surinamese seem somewhat similar to those between African migrants, Caribbean migrants, and local Afro-Americans in the United States. See chapters 16, 17, and chapter 19, note 3.

26. A slightly later retrospective overview of the anthropology of West Africa by Elizabeth Tonkin (1990) is especially enlightening on the British colonial tradition. See also chapter 1, note 5 .

27. While much more could be said about the field of literary anthropology, a handful of references may exemplify its diversity and growth: Archetti 1994; Brettell 2015; Clifford and Marcus 1986; Fassin 2014; Gottlieb 2015; Narayan 2007; Waterston and Vesperi 2009; and Wulff 2016, 2017. ReedDanahay (1997) offers an early overview of the varied uses of the term "autoethnography," showing its links to the history of anthropology.

28. One of the pioneer contributions to a literary anthropology actually resulted from a field study in Nigeria: Return to Laughter (1954), written under the pseudonym "Elenore Smith Bowen" by Laura Bohannan, based on her field experience among the Tiv. I say a little more about this in chapter 13.

29. I include here also scholars of Nigerian background, now active in U.S. academia—see, e.g., Adesokan 2011 and Eze 2011.

30. For my other endeavors in "studying sideways," see Hannerz 2004b on the work and life of foreign correspondents, and Hannerz 2016 on the genre of future scenarios. In an earlier essay launching the notion, I also identify missionaries and spies as occupational categories engaged in transnational knowledge production (Hannerz 1998).

31. Later on, Rhonda Cobham (2016), literary scholar of Caribbean background, has argued that the early generation of Nigerian novelists were under the influence of anthropological writing-in some instances perhaps by way of personal contacts with amateur or professional anthropologists, but also because such writings as they came across about their own societies were often by anthropologists. If some of their novels were fairly rich in ethnography, of course, it may also have been because a readership that was in large part abroad may have needed such cultural contextualization of the plot, and was interested in it. On the relationship between early Nigerian fiction and anthropology, within a context of postcolonial critique, see also Huggan 2001: 34-57.

For a broader, critical view of the relationship between mid-twentiethcentury African fiction and social science, see an essay by Simon Gikandu (2016), Kenyan-American literary scholar. It is amusing to learn, from the prominent African American literary scholar Henry Louis Gates, Jr. (1992: 88), in an essay in his Loose Canons, that both Wole Soyinka and Emmanuel Obiechina-see chapter 6-had told him that at Cambridge University they had somehow had to identify with social anthropology, in an early period when that center of learning did not yet recognize African literature as an academic field.

On the relationship between anthropology and fiction (and semifiction), see also the perceptive analysis by Quayson (2003: 1-30), focusing on Amitav Ghosh's In an Antique Land (1992). Ghosh, a highly productive 
Indian author, also has an Oxford doctorate in anthropology. See, too, chapter 1 , note 5 .

32. Another recent example of Nigerian-American fiction inspired by traditional cosmology is Akwaeke Emezi's first novel, Freshwater (2018), with complicated spiritual beings taking their place in a tricontinental family life.

33. I had my own encounter with Obioma at a public appearance in Stockholm, as a translation of An Orchestra of Minorities into Swedish was launched. Before that, I was intrigued to learn, from an essay in the New York Times Book Review (Obioma 2018), that during his childhood in Akure, his father had turned him on to reading by handing him a well-worn copy of Amos Tutuola's The Palm-Wine Drinkard. So here was an Igbo boy, in what was largely a Yoruba town, finding his way to literature by way of a pioneer Yoruba author who could give him a sense of how to draw creatively on Nigerian oral tradition. Then, as the next step, Obioma's father took his son to a public library.

34. American anthropology had another kind of beginning, with a concentration, until after World War II, on studies of Amerindian cultures. Other settler countries with indigenous people in their territories have followed a similar pattern.

35. A key volume here was Anthropology \& the Colonial Encounter (1973), edited by Talal Asad-not a volume, however, where Nigeria figures very importantly.

36. On the history of the African Writers Series, see Currey 2008 and Oloko 2016. James Currey edited the series for a number of years, together with Chinua Achebe. Adewale Maja-Pearce (see chapter 18) came in as series editor later.

37. See Derrick's (2018) monograph on the historical role of the weekly West Africa, focusing on its first editor, Albert Cartwright.

38. At Collet's in the 1960s, one would also find, for instance, the publications from Umkhonto na Zikwe, the armed wing of Nelson Mandela's African National Congress.

\section{References}

Adamu, Yusuf M. 2002. "Between the Word and the Screen: A Historical Perspective on the Hausa Literary Movement and the Home Video Invasion." Journal of African Cultural Studies 15: 203-213.

Adéèkó, Adélekè. 2017. Arts of Being Yoruba. Bloomington: Indiana University Press.

Adesokan, Akin. 2011. Postcolonial Artists and Global Aesthetics. Bloomington: Indiana University Press.

Adichie, Chimamanda Ngozi. 2013. Americanah. London: Fourth Estate. Alter, Alexandra. 2017. “Nigeria's Literary New Wave." New York Times, 24 November. 
Anderson, Benedict. 1983. Imagined Communities. London: Verso.

Andersson, Ruben. 2014. Illegality, Inc. Berkeley: University of California Press. Andrikopoulos, Apostolos. 2013. "Migration, Class and Symbolic Status: Nigerians in the Netherlands and Greece." In Alessandro Triulzi and Robert Lawrence McKenzie (eds.), Long Journeys: African Migrants on the Road. Leiden: Brill.

Archetti, Eduardo P. (ed.). 1994. Exploring the Written: Anthropology and the Multiplicity of Writing. Oslo: Scandinavian University Press.

Asad, Talal (ed.). 1973. Anthropology \& the Colonial Encounter. London: Ithaca Press.

Azikiwe, Nnamdi. 1961. Zik: A Selection from the Speeches of Nnamdi Azikiwe. London: Cambridge University Press.

Bohannan, Laura. 1966. "Shakespeare in the Bush." Natural History 75(7): 28-33.

Brettell, Caroline B. 2015. "Writing Culture: Anthropology and Literature." In C. B. Brettell (ed.), Anthropological Conversations: Taking Culture across Disciplines, 61-87. Lanham: Rowman \& Littlefield.

Clifford, James, and George E. Marcus (eds.). 1986. Writing Culture: The Poetics and Politics of Ethnography. Berkeley: University of California Press.

Cobham, Rhonda. 2016. "Forewords and Foreskins: The Author as Ethnographer in Early West African Fiction." In Eileen Julien and Biodun Jeyifo (eds.), The Locations and Dislocations of African Literature. Trenton, NJ: Africa World Press.

Cohen, Robin, and Olivia Sheringham. 2016. Encountering Difference. Cambridge: Polity.

Currey, James. 2008. Africa Writes Back. London: James Currey.

Derrick, Jonathan. 2018. Africa, Empire and Fleet Street. London: Hurst.

De Witte, Marleen. 2019. "Black Citizenship, Afropolitan Critiques: Vernacular Heritage-Making and the Negotiation of Race in the Netherlands." Social Anthropology 27(4): 609-625.

Durán-Almarza, Maria, Ananya Kabir, and Carla Rodríguez González. 2017. "Introduction: Debating the Afropolitan." European Journal of English Studies 21: 107-114.

Ede, Amatoritsero. 2016. “The Politics of Afropolitanism.” Journal of African Cultural Studies 28: 88-100.

Ellis, Stephen. 2016. This Present Darkness. London: Hurst.

Emezi, Akwaeke. 2018. Freshwater. New York: Grove Press.

Evaristo, Bernardine. 2019. Girl, Woman, Other. London: Hamish Hamilton.

Eze, Chielozona. 2011. Postcolonial Imagination and Moral Representations in African Literature and Culture. Lanham, MD: Lexington Books.

- 2014. "Rethinking African Culture and Identity: The Afropolitan Model.” Journal of African Cultural Studies 26: 232-247.

Fabian, Johannes. 1978. "Popular Culture in Africa: Findings and Conjectures." Africa 48: 315-34.

Fassin, Didier. 2014. "True Life, Real Lives: Revisiting the Boundaries between Ethnography and Fiction." American Ethnologist 41: 40-55.

Furniss, Graham. 2006. "Innovation and Persistence: Literary Circles, New Opportunities, and Continuing Debates in Hausa Literary Production." 
In Karin Barber (ed.), Africa's Hidden Histories. Bloomington: Indiana University Press.

Gates, Henry Louis, Jr. 1992. Loose Canons. New York: Oxford University Press.

Gehrmann, Susanne. 2016. "Cosmopolitanism with African Roots: Afropolitanism's Ambivalent Mobilities." Journal of African Cultural Studies 28: 61-72.

Ghosh, Amitav. 1992. In an Antique Land. New York: Vintage.

Gikandu, Simon. 2016. "African Literature and the Social Science Paradigm." In Eileen Julien and Biodun Jeyifo (eds.), The Locations and Dislocations of African Literature. Trenton, NJ: Africa World Press.

Gingrich, Andre, and Ulf Hannerz. 2017. "Introduction: Exploring Small Countries." In Ulf Hannerz and Andre Gingrich (eds.), Small Countries: Structures and Sensibilities. Philadelphia: University of Pennsylvania Press.

Gordon, Jane Anna. 2014. Creolizing Political Theory. New York: Fordham University Press.

Gottlieb, Alma. 2015. “Anthropological Writing.” In J. D. Wright (ed.), International Encyclopedia of the Social \& Behavioral Sciences, 2nd ed., 740745. Oxford: Elsevier.

Griswold, Wendy. 2000. Bearing Witness: Readers, Writers, and the Novel in Nigeria. Princeton, NJ: Princeton University Press.

Hannerz, Ulf. 1976. "Methods in an African Urban Study." Ethnos 41: 68-98.

- 1982. "Washington and Kafanchan: A View of Urban Anthropology." L'Homme 22(4): 25-36.

- 1987. “The World in Creolisation.” Africa 57: 546-559.

- 1989. "Culture between Center and Periphery: Toward a Macroanthropology." Ethnos 54: 200-216.

- 1992. Cultural Complexity. New York: Columbia University Press.

- 1996. Transnational Connections: Culture, People, Places. London: Routledge.

- 1998. "Other Transnationals: Perspectives Gained from Studying Sideways." Paideuma 44: 109-123.

_. 2004a. "Cosmopolitanism.” In Joan Vincent and Daniel Nugent (eds.), Companion to the Anthropology of Politics. Oxford: Blackwell, 2004.

- 2004b. Foreign News: Exploring the World of Foreign Correspondents. Chicago: University of Chicago Press.

- 2016. Writing Future Worlds: An Anthropologist Explores Global Scenarios. New York: Palgrave Macmillan.

- 2019. World Watching: Streetcorners and Newsbeats on a Journey through Anthropology. London: Routledge.

- 2022. "Kafanchan: A Nigerian Town and Its Global Horizons." In Deborah Pellow and Suzanne Scheld (eds.), Africa and Urban Anthropology: Theoretical and Methodological Contributions from Contemporary Fieldwork. London: Routledge.

Hannerz, Ulf, and Andre Gingrich (eds.). 2017. Small Countries: Structures and Sensibilities. Philadelphia: University of Pennsylvania Press.

Harris, Ashleigh. 2020. Afropolitanism and the Novel. London: Routledge. 
Hart, Keith. 1985. “The Social Anthropology of West Africa.” Annual Review of Anthropology 14: 243-272.

Hill, Sam. 2020. “The Nigerian Century.” Newsweek, 24 January, 30-45.

Hodapp, James. 2016. “The Proto-Afropolitan Bildungsroman: Yoruba Women, Resistance, and the Nation in Simi Bedford's Yoruba Girl Dancing." The Global South 10(1): 130-149.

Huggan, Graham. 2001. The Postcolonial Exotic. London: Routledge.

Julien, Eileen. 2006. “The Extroverted African Novel.” In Franco Moretti (ed.), The Novel. Princeton, NJ: Princeton University Press.

Last, Murray. 1970. “Aspects of Administration and Dissent in Hausaland, 1800-1968." Africa 40: 345-357.

Lindfors, Bernth. 2010. Early West African Writers. Trenton, NJ: Africa World Press.

Mamdani, Mahmood. 1996. Citizen and Subject. Princeton, NJ: Princeton University Press.

Mathews, Gordon, Linessa Dan Lin, and Yang Yang. 2017. The World in Guangzhou: Africans and Other Foreigners in South China's Global Marketplace. Chicago: University of Chicago Press.

Mbembe, Achille. 2007. “Afropolitanism.” In S. Njami and L. Durán (eds.), Africa Remix: Contemporary Art of a Continent. Johannesburg: Johannesburg Art Gallery.

. 2020. Afropolitanism. Nka: Journal of Contemporary African Art 46: $56-61$.

Meyer, John W. 1999. "The Changing Cultural Content of the Nation-State: A World-Society Perspective." In George Steinmetz (ed.), State/Culture. Ithaca, NY: Cornell University Press.

Mills, David. 2008. Difficult Folk? A Political History of Social Anthropology. Oxford: Berghahn.

Nader, Laura. 1972. "Up the Anthropologist-Perspectives Gained from Studying Up.” In Dell Hymes (ed.), Reinventing Anthropology. New York: Pantheon.

Narayan, Kirin. 2007. Tools to Shape Texts: What Creative Nonfiction Can Offer Ethnography. Anthropology and Humanism 32: 130-144.

Ndibe, Okey. 2016. Never Look an American in the Eye. New York: Soho.

Newell, Stephanie. 2006. West African Literatures. Oxford: Oxford University Press.

Obioma, Chigozie. 2018. “The Light Under the Bushel.” New York Times Book Review, 9 December, 20.

- 2019. An Orchestra of Minorities. New York: Little, Brown.

Oloko, Patrick. 2016. "In Whose Image or Likeness? Publishing and the Literary Order in Early Post-colonial Nigeria.” In Ute Röschenthaler and Mamadou Diawara (eds.), Copyright Africa. Canon Pyon: Sean Kingston.

Oreh, O. O. 1985. "Masquerade and Other Plays on Nigerian Television." In Frank Okwu Ugboajah (ed.), Mass Communication, Culture and Society in West Africa. Munich: Hans Zell/K. G. Saur.

Orizu, Nwafor. 1944. Without Bitterness. New York: Creative Age Press.

Perham, Margery. 1960. Lugard: The Years of Authority, 1898-1945. London: Collins. 
Pilling, David. 2018. "Lunch with the FT: Aliko Dangote: 'Only the Toughest of the Tough Survive Here.”' Financial Times Weekend, 14-15 July.

Pitts, Johny. 2019. Afropean: Notes from Black Europe. London: Allen Lane/ Penguin.

Quayson, Ato. 1994. "Unthinkable Nigeriana: Crisis in the Idea of the African Nation-State." In Gabriel Gbadamosi and Ato Quayson, Redrawing the Map: Two African Journeys. Cambridge: Prickly Pear Press.

- 2003. Calibrations. Minneapolis: University of Minnesota Press.

Reed-Danahay, Deborah E. 1997. "Introduction." In Auto/Ethnography: Rewriting the Self and the Social. Oxford: Berg.

Rich, Motoko, and Emmanuel Akinwotu. 2018. "Bobsledders for Nigeria Break Barriers." New York Times, 26 February.

Selasi, Taiye. 2013. Ghana Must Go. London: Penguin.

Skinner, Ryan Thomas. 2015. Bamako Sounds. Minneapolis: University of Minnesota Press.

Smith Bowen, Elenore. 1954. Return to Laughter. New York: Harper.

Stewart, Charles (ed.). 2007. Creolization: History, Ethnography, Theory. Walnut Creek, CA: Left Coast Press.

Suhr-Sytsma, Nathan. 2018. "The Extroverted African Novel and Literary Publishing in the Twenty-First Century." Journal of African Cultural Studies 30: 339-355.

Taub, Ben. 2017. We Have No Choice: "The Desperate Journey of Blessing, One of the Nigerian Girls Who Try to Reach Europe." New Yorker, 10 April.

Tonkin, Elizabeth. 1990. "West African Ethnographic Traditions.” In Richard Fardon (ed.), Localizing Strategies. Edinburgh: Scottish Academic Press.

Uimonen, Paula. 2019. "Muse and Power: African Women Writers and Digital Infrastructure in World Literature." Anthropology and Humanism 44: 20-37.

- 2020. Invoking Flora Nwapa: Nigerian Women Writers, Femininity and Spirituality in World Literature. Stockholm: Stockholm University Press.

Waterston, Alishe, and Maria. D. Vesperi (eds.). 2009. Anthropology off the Shelf: Anthropologists on Writing. Oxford: Wiley-Blackwell.

Wulff, Helena. 2016. The Anthropologist as Writer: Genres and Contexts in the Twenty-First Century. Oxford: Berghahn.

- 2017. Rhythms of Writing: An Anthropology of Irish Literature. London: Bloomsbury. 


\section{Palm Wine, Amos Tutuola, and a Literary Gatekeeper}

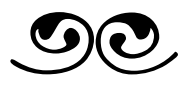

Once or twice it happened that I went in the late morning with my research assistant, a local young man, to Ungwar Rimi, a village just outside Kafanchan, to see a tapster who would just be coming down from the palm trees, and could serve the fresh harvest in a calabash. Unfermented, this was of course literally palm juice rather than actually palm wine. The palm wine bars in Kafanchan would be serving the stronger stuff. Although I once ran into a son of the local Hausa emir in one of them, they drew mostly a southern Nigerian clientele. The local drink around Kafanchan, popular not least at market places, was burukutu, made from Guinea corn or millet.

So it is appropriate that Amos Tutuola, the author of The PalmWine Drinkard (1952), the first work of Nigerian fiction to really draw international attention, was a Southern Nigerian. (Meanwhile, it seems that the great burukutu novel remains to be written.)

My first copy of The Palm-Wine Drinkard was in Swedish, one of apparently about a dozen languages into which it was translated. Dated in 1961, it was launched in a new book series of "contemporary novels from the entire world," each with an introduction by a well-known Swedish literary figure, Artur Lundkvist, with a reputation for knowing about more faraway literatures. In this instance, the introduction does not at first seem so promising: "About Amos Tutuola from Nigeria not much is known. It appears he is a negro of the peaceful Yorouba [sic] people ..." (my translation). But as it continues, Lundkvist shows his fascination with Tutuola's story, noting themes and high points, and making an effort to mediate culturally between the text and its Swedish readers. Some of the traces of social critique that Lundkvist detects seem a bit Borealist, and might have puzzled Tutuola if he had ever come across them. 
The palm-wine drinkard's story, told in the first-person singular, is a weird tale of encounters and events, with people and unpeople. The drinkard starts out as a rather spoiled young man, presented with a plantation of 560 thousand palm trees by his father, with an expert tapster to go with it. Indeed, he spends his days drinking, but there is enough for a great many people to start dropping by to share the liquid produce.

Then disaster strikes: the father dies, and a little later that tapster falls down from a tree and dies, too. There is no palm wine, and those thirsty friends are gone. So the drinkard embarks on a quest to find his tapster, in the Land of the Dead, to persuade him to come back. That becomes a very extended adventure. He brings all his juju tools that his father left behind, and occasionally they became useful: when it is practical, for example, to transfigure into a bird. For a time he works for a man who had lost his beautiful daughter. She had had a stall in the market place, but had been drawn to an extraordinarily attractive man, and had followed after him when the market closed for the day. But how surprised she was when she found that along the way he returned all his beautiful features, one by one, to their rightful owners, and paid rent for them! In the end he had only his skull left, and went back to his frightening community, where everybody was only a skull. The palm-wine drinkard fights the skulls and liberates her, and her father therefore allows him to marry the girl. And so, continuing through the Land of the Dead, there are now the two of them. Eventually, after more striking experiences, they find the dead tapster, rather more alive and well in this special territory (although walking only backward), but they are told that there is no way he can come with them-once you are a denizen of the Land of the Dead, that is where you stay.

The two of them, however, do manage to get out-as they had never really died, they had just been there as visitors. They also bring a wonderful egg that the dead tapster had given them as a farewell gift. Back in the drinkard's home town, life could return more or less to normal. (Returning from the Land of the Dead, perhaps the drinkard was already a been-to of sorts?) There had been a terrible hunger, however, with millions of people dying, and others reduced to eating their own children. That wonderful egg helps, so in some miraculous way or other, there is soon food for everybody. Moreover, after a long period of drought, causing famine, the rains come back. And around there, the palm-wine drinkard's story ends.

When The Palm-Wine Drinkard was published in England, there was an enthusiastic review in The Observer, the quality Sunday newspaper, 
by Dylan Thomas, and that probably contributed to its quick success: "This is the brief, thronged, grisly and bewitching story, or series of stories, written in young English by a West African ...."1 The fact that I first encountered The Palm-Wine Drinkard in Swedish, however, as Palmvindrinkaren, meant that I would not be immediately aware of one fact that quickly caused controversy in Tutuola's home country. Dylan Thomas had it as "young English," and indeed Tutuola's language of writing was not exactly Standard English. More or less highly educated Nigerian contemporaries, anxious not to deviate noticeably from correct form, were inclined to look down on Tutuola's somewhat creolized Yoruba English. Moreover, some anxiety might be involved. Would such idiosyncrasy of style actually fuel a belief among an overseas readership that Africans were still only half-educated semiliterates?

Tutuola had indeed had rather little formal schooling. He came from a family of cocoa farmers, became at age seven the servant of an Igbo man who, instead of paying him, put him in a Salvation Army primary school. He continued from there to an Anglican school but left after altogether six years of education, trained as a blacksmith, and worked as a breadseller and a messenger. ${ }^{2}$ But he had learned to write, and so he went on to explore what he could do with it. Later writers, Nigerian and/or Afropolitan, such as Ken Saro-Wiwa and Uzodinma Iweala, have made a point of engaging with styles of "bad English" more playfully. Some sixty years later, too, finding a website named BBC Pidgin, catering to a Nigerian audience, one could wonder who had the last laugh. ${ }^{3}$

Abroad, readers tended to invent their own Tutuolas: one finds the Yoruba heritage, another finds Jungian stereotypes, yet another the globally recurrent mythological themes of a Joseph Campbell. ${ }^{4}$ Perhaps a temporally fitting metaphor for the variety of imaginative readings of a mid-twentieth-century body of work is that Tutuola's writings offer readers a Rorschach test, with the polysemy of given inkblot forms meeting their personal minds. ${ }^{5}$

And then some twenty-first-century readers might place The PalmWine Drinkard in a fantasy genre. As it turned out, it would not be the last time the work of a Nigerian writer has crossed the borders of conventional genres.

Amos Tutuola continued to write, yet nothing could equal the success of his first published book. My Life in the Bush of Ghosts (1954), Simbi and the Satyr of the Dark Jungle (1955), and Feather Woman of the Jungle (1962), following in fairly quick succession, could all be good reads, but did not have the massive surprise value of The Palm-Wine Drinkard. 
Still he continued to write. His last novel, Pauper, Brawler and Swindler (1987) came out thirty-five years after his first, with the same publisher, Faber and Faber, in London's Bloomsbury. (And there would be yet another collection of stories.) While writing, he held a rather modest storekeeper job at the government radio station in Ibadan, which is where I went to greet him once in the early 1960s. He came out to see me in a green shirt and shorts, markings on his cheeks, listening seemingly anxiously, speaking eagerly, his voice turning to falsetto as he replied. In the early 1980s, he made a brief visit to the land of the academics, as an associate of the International Writing Program at the University of Iowa. He died in 1997, aged 77. The manuscript of The Palm-Wine Drinkard, as well as Tutuola's eyeglasses and driver's license, are now in a rich collection of Africana at the University of Texas. ${ }^{6}$

Another twenty years later, and some two-thirds of a century after The Palm-Wine Drinkard appeared, there was Francis B. Nyamnjoh's Drinking from the Cosmic Gourd: How Amos Tutuola Can Change Our Minds (2017). Nyamnjoh is a Cameroonian anthropologist, at the time of writing a professor at the University of Cape Town, publishing extensively and at times controversially in his academic field, but also writing novels, and, moreover, running his own publishing house out of Bamenda, Cameroun. ${ }^{7}$ The book has a brief foreword by Richard Fardon, a British anthropologist with extensive experience of northeastern Nigeria. Fardon perhaps makes a gesture toward taming the thought that has gone into the body of the text, but mostly he forewarns of the academic fireworks on the pages that follow.

Nyamnjoh brings a wide-ranging set of intellectual tools and baggage to his inquiry into the enduring meaning of Tutuola's work. Frantz Fanon, Pierre Bourdieu, and V. S. Naipaul are all there. So are J. K. Rowling, author of the Harry Potter bestsellers, and Roald Dahl. African authors are also on the scene: Chinua Achebe, Wole Soyinka, Okot p'Bitek, Ngugi wa Thiongo. Nyamnjoh's own discipline gets occasional attention, too, and he cites another writer who compares the palm-wine drinkard, exploring the Land of the Dead, to an amateur ethnologist (Rooney 2000: 82). A chapter is devoted to considering the cultural affinities between Tutuola's Yoruba-based imagination and Nyamnjoh's own homeland in the Cameroon grasslands. The product, for anyone examining the results of Nyamnjoh's investigative endeavor, is impressively rich.

Not least, however, does Nyamnjoh emphasize some key concepts for an understanding of human life that can be drawn out of Tutuola's work, and that he feels may serve to revitalize contemporary world 
views and academic thought. Tutuola is a precursor to recent debates on flexible and fluid categories, social and biological bodies. There is conviviality-a term elsewhere put to somewhat different uses, but here referring to what has also been termed sociality, the basic fact that human life is relational, rather than solitary or individual. There is incompleteness: "To seek or claim completeness is to ignore, to one's peril, the reality of imperfection and impurity as the normal order of things and being" (Nyamnjoh 2017: 21). All in all, Tutuola offers "a basket of possibilities for exploring and entertaining conversations with consciousness" (Nyamnjoh 2017: 27). It celebrates what it means to be a "frontier being," at the crossroads and junctions of multiple influences and potentialities. Frontier Africans, straddling identity margins, bridging varied divides, will "recognize and provide for the interconnections, nuances and complexities in their lives made possible or exacerbated by technologically inspired and enhanced mobilities and encounters" (Nyamnjoh 2017: 3). Perhaps we can sense here some particular intellectual challenges to Afropolitans, as frontier beings?

So much for now for Amos Tutuola and his commentators. But, in fact, the Swedish writer who contributed that introduction to the translation Palmvindrinkaren deserves some attention as well, in the context of a literary history of Nigeria. Artur Lundkvist was born on a small farm in southern Sweden. But he grew up to turn left politically, and to travel in much of the world, an unusual cosmopolitan for his time. In 1951, Negerland, his account of a journey through Africa, was published (in Swedish, of course); the journey would seem to have occurred in the late 1940s. In large part Lundkvist traveled overland, crossing the Sahara by French colonial bus services, passing Agadèssomewhat the same route as taken by West African refugees in the twenty-first century, but in the opposite direction. Arriving in Nigeria, he stayed at the rather unassuming Hotel de France in Kano. (I remember it was still there some thirty years later.) In front of the hotel, he could rent a bike to ride around town and along the mud walls of the old city. Despite the human diversity, his strongest visual impression may have been the flocks of bats at dusk and the white owl he found in his bedroom one night.

From Kano to Lagos he took the train. Secluded from the mass of local third-class passengers, he would share his compartment with a Greek and an Indian, both in local businesses; the Greek was somewhat ill at ease with having the Indian there, as he considered him "colored."

Lundkvist's Lagos was a dazzlingly lively place:

Toward the evening the houses of the Whites wake up, all doors and windows are opened, family and social life begin on verandahs and 
balconies. They play cards forever, everywhere, with a brief break now and then for a drink and a cigar. The women play, too, or lift their arms easily over an embroidery, or hurry around in the rooms under the lit lamps. Occasionally a piano is heard: a spasmodic musical craft. But you seldom see anybody reading. They sit there, encapsulated in their circles of electric light, inaccessible above the wallowing dark city. (Lundkvist 1951: 114)

On the other hand, there are the varieties of locals:

There are the Black gentlemen in shining cars, infinitely superior as they sweep past a poor pedestrian European. There are mission-type Negroes, in dark dress, struggling to be pious, stiff from idealist selfconsciousness. There are ragged hooligans, with insolent eyes and big mouths, unwilling to get out of the way of anything. There are snobs in European, Islamic, Indian or African attire, deeply contemptuous of any style imitation except their own. There are demobilized jungle soldiers from Burma, who have learnt to whistle after White women, too, and to shout American impertinences. (Lundkvist 1951: 115)

He could observe a ritual feast, and a street brawl, and a lively sex trade, and the crowd gathering around a wizard or a political agitator. The street scene included animal life: goats, pigs, tame monkeys, snakes, parrots, turtles. (Perhaps the farm boy Lundkvist took special notice of animals in the streets, as matter out of place.) In the evening, life in the alleys might quiet down. But the morning would start early, with Muslim prayers from the rooftops mixing with the loud cries of a multitude of roosters.

One could see parallels between Lundkvist's portrayal of Lagos and that offered by Nigerian novelists some years later-although for him, the colonialist presence was still conspicuous. The etiquette of race relations was based on strict hierarchy, as well as mutual incomprehension. The British, in administration and in business, would withdraw to their own neighborhoods after the working day was over, for card games or whatever. Some evidently preferred colonial expat living to being in a Britain that had come under a post-World War II socialist government.

From Lagos, this traveler had side trips to Ibadan and Abeokuta, sizeable cities but still inhabited mostly by farmers. The Public Relations Department of the colonial administration had provided him with a car and a chauffeur. In Abeokuta, he was received by the resident high-level colonial administrator, who lived on a hill in his out-of-the-way villa, but could still hear the native drumming going on forever, every night. Lundkvist was also taken to a school, where he had a long interview with an eloquent, intensely nationalist female 
head teacher. Nowhere in his reporting on Nigeria did Lundkvist name names. People remained types, rather than individuals. But there is every reason to recognize this teacher as Funmilayo Ransome-Kutiindeed a prominent political figure, in party politics and as the leader of a women's movement, although later also known as the mother of Fela Kuti, the Afrobeat musician. At the time of Lundkvist's visit in Abeokuta, Fela would have been about ten years old. Some thirty years later, in 1978, when Fela's famous compound, the Kalakuta Republic in Lagos, was stormed by soldiers, his mother, who was staying with him, suffered injuries from which she eventually died. Abeokuta, of course, was also Amos Tutuola's hometown, but at the time of his visit there, Lundkvist certainly did not know of that as-yet-unpublished writer.

Returning to Lagos from his Yorubaland excursion, Artur Lundkvist would next depart by boat for Matadi in the Belgian Congo. The Nigerian part of his African journey was over.

In his book there would be about sixty-five pages about Nigeria, as far as I know never translated from Swedish into any other language. As in the case of The Palm-Wine Drinkard, one could again sense a potential language controversy: a twenty-first-century reader of Negerland might be annoyed by the title, and find it disconcerting that even this enlightened, radical writer is so immersed in colonial discourse-not outright racist, but using a vocabulary of primitiveness and backwardness as a matter of course. This was the time of old-style colonialism's last hurrah, but its echoes infiltrated far-away Swedish discourse as well. Lundkvist could not entirely escape it. ${ }^{8}$

He would go on to prominence in Swedish literary and public life. When he was awarded a Lenin Prize by the Soviet Union, he denied he was ever a Communist. Elected as a member of the Swedish Academy, he was widely understood to be its unofficial expert on more exotic literatures. To a degree, he became thereby a gatekeeper for the Academy's awards of Nobel Prizes in literature. This seems, for one thing, to have involved a long and successful campaign to hinder a prize for Graham Greene-who was, of course, another traveler in Africa. Did he have a part in the award of a prize to Wole Soyinka in 1986? It is difficult to say, as Academy proceedings remain secret for a very extended period. He had by then long been ill, but it seems likely that he had been involved in the groundwork, as awards are not made in a hurry. Artur Lundkvist died in 1991. His first farm home is now a museum and a guest house for writers.

Then, finally, almost fifty years after Tutuola's palm-wine drinkard and his search for his lost tapster, came another palm-wine tapster, in the short story "What the Tapster Saw," included in one of Ben Okri's 
(1999) collections. This tapster tied three empty gourds to his bicycle and rode out toward the palm trees. Times had changed, we sense-he came to a signboard that read "DELTA OIL COMPANY: THIS AREA IS BEING DRILLED. TRESPASSERS IN DANGER." But he continued on to a cluster of palm trees that looked promising. He climbed one of them, but fell. As he woke up, he started having strange experiences. He met three turtles, for example, one of which had the face of a friend of his, an herbalist named Tabasco. Witch doctors tried to prevent torrential rains from falling in an area where the oil company wanted to drill, but as they failed, the company flew in an expatriate with explosives left from the last war, and that somehow worked. The tapster also saw people being shot: in coups, in secret executions, in armed robberies. Other unusual things happened, but eventually he ran into Tabasco, who told him he had actually been dead for a week. So here again we have been in the Land of the Dead.

\section{Notes}

1. Dylan Thomas' review, "Blithe Spirits," was in The Observer on 6 July 1952. Before that, as the Tutuola manuscript arrived in London, the response in local publishing circles had apparently been happy-puzzled. I learned from Bernth Lindfors's (2010) careful mapping of consultations between editors and Africa experts that the advice of Daryll Forde was also sought, and was favorable; Forde was a professor of anthropology at the University College London, and the director of the International Africa Institute (again, Lord Lugard's creation, in 1926). He had also done field research of his own among the Yakö, at the extreme southeastern corner of Nigeria. We encounter him again early in chapter 12. I was Forde's guide in Stockholm for a day some time in the early 1960s, when he was in town for a meeting connected to the International Africa Institute. At the Institute, Forde long had the administrative assistance of Barbara Pym, doubling as a well-known novelist, who has offered not entirely flattering portrayals of anthropologists in a couple of her books-Less than Angels (1955) and An Academic Question (1986).

2. I have the information about Tutuola's early life from the current Wikipedia entry. Perhaps his Abeokuta origins and his early schooling contributed to the fact that he took to writing in English-he interacted with an Igbo master, and his schooling was probably largely in English. And he was not a Lagos Yoruba. In Lagos there had already been a lively Yoruba publishing scene for many decades (see, e.g., Barber 2012).

3. See a New York Times report by Freytas-Tamura (2017).

4. One rather early commentator, Gerald Moore (1962: 42), writes about Tutuola that "he is something much rarer and more interesting than another novelist; he is a visionary, and his books are prose epics rather 
than novels." Moore had been an extramural tutor in Igboland in the 1950s; in the acknowledgments for his book he thanks Ulli Beier (see chapter 6) for his work and for stimulating conversations.

5. In a somewhat wider context, one could remember that in the 1960s and 1970s, there was an upsurge of interest among anthropologists and historians in the supposedly great divide, with regard to thought and communication, between societies depending on orality only and those who had come to combine it with literacy. One book by the British anthropologist Jack Goody, who had a major part in initiating this field of scholarly debate, had the provocative title The Domestication of the Savage Mind (1977). Goody had a long-term intensive involvement in West African studies-primarily in the Gold Coast, turning into Ghana, but one can hardly doubt that he was aware of Tutuola's writings. Yet, perhaps in his own dealings with the topic, he may have avoided transgressing the academic boundary between anthropology and comparative literature, and so Tutuola's creative brokerage between orality and writing gets no mention here. Goody, a scholar displaying his intellectual creativity in many areas, was a professor of social anthropology at the University of Cambridge, long a center of West African anthropology. In the introduction we encountered Keith Hart and G. I. Jones, both Cambridge anthropologists, commenting on potential or real linkages between anthropology and fiction. We can note later, in chapter 13, that this was also where Ibrahim Tahir would earn his doctorate. One gets a sense of its importance in Goody's (1995) overall account of British anthropology in colonial and early postcolonial times, with research in Nigeria discussed in various places, and in a more autobiographical account (Goody 1991).

6. I am grateful to Bernth Lindfors for informing me about the holdings of the Harry Ransom Center at the University of Texas, Austin-including also, for example, handwritten materials by, or involving, Chinua Achebe and Wole Soyinka.

7. Some years earlier, Nyamnjoh (2011) commented on the troubled relationship between anthropology and African intellectuals, suggesting that fiction could play a mediating role; his example is a novel of his own, on "bushfallers," somewhat like a latter-day Cameroonian counterpart of "been-tos."

8. One may want to compare it with Geoffrey Gorer's account of a journey mostly through France's West African territories in the mid-1930s, in Africa Dances (1945) - a mixture of sometimes astute observations with frequently bizarre interpretations.

\section{References}

Barber, Karin. 2012. Print Culture and the First Yoruba Novel. Leiden: Brill. Freytas-Tamura, Kimiko de. 2017. "The BBC in Pidgin? People Like It WellWell.” New York Times, 30 December. 
Goody, Jack. 1977. The Domestication of the Savage Mind. Cambridge: Cambridge University Press.

- 1991. "Towards a Room with a View: A Personal Account of Contributions to Local Knowledge, Theory, and Research in Fieldwork and Comparative Studies." Annual Review of Anthropology 20: 1-23.

- 1995. The Expansive Moment. Cambridge: Cambridge University Press.

Gorer, Geoffrey. 1945. Africa Dances. Harmondsworth: Penguin.

Lundkvist, Artur. 1951. Negerland. Stockholm: Bonniers.

Moore, Gerald. 1962. Seven African Writers. London: Oxford University Press.

Nyamnjoh, Francis B. 2011. "Cameroonian Bushfalling: Negotiation of Identity and Belonging in Fiction and Ethnography." American Ethnologist 38: 701-713.

2017. Drinking from the Cosmic Gourd. Mankon, Cameroun: Langaa.

Okri, Ben. 1999. Stars of the New Curfew. London: Vintage.

Pym. Barbara. 1955. Less Than Angels. London: Jonathan Cape. 1986. An Academic Question. London: Macmillan.

Rooney, C. 2000. African Literature, Animism and Politics. London: Routledge. Tutuola, Amos. 1952. The Palm-Wine Drinkard. London: Faber and Faber.

-1954. My Life in the Bush of Ghosts. London: Faber and Faber.

-1955. Simbi and the Satyr of the Dark Jungle. London: Faber and Faber.

- 1961. Palmvindrinkaren. Stockholm: Tiden.

- 1962. Feather Woman of the Jungle. London: Faber and Faber.

-1987. Pauper, Brawler and Swindler. London: Faber and Faber. 


\section{Bahia-Lagos-Ouidah Mariana's Story}

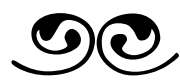

While most of the writings to be encountered in these essays are by Nigerian authors, I include a couple of non-Nigerian writers from an early period, who wrote about even earlier times in Nigeria. One of them was Antonio Olinto, a Brazilian writer of some distinction. In 1997, he became a member of the Brazilian Academy of Letters; he died in 2009, aged 90. His novel A Casa da Agua was published in Portuguese in Brazil in 1969, and appeared in translation as The Water House with a British publisher a year later.

The Water House chronicles the life of an Afro-Brazilian family over seventy years, 1898-1968. It begins in the central Brazilian state of Minas Gerais, with an elderly woman, Catarina, recently freed from slavery, making a big decision. (Brazil was the last major country in the Americas to abolish slavery, in 1888.) Catarina would return to Africa, together with several of her descendants. She had grown up in Abeokuta, a large inland West African town (and, as we saw in chapter 1, later Amos Tutuola's home town), but an uncle based in the bustling port city Lagos had invited her to visit—and then promptly turned her into merchandise in the Transatlantic slave trade.

So she spent most of her life in Brazil, and had children and grandchildren. Now she would use such savings as she had to take a number of them to Bahia, the major port (more lately known as Salvador de Bahia, or just Salvador). From there they would get on a modest sailing vessel for that belated return journey across the South Atlantic. It was a difficult journey. The passengers suffered, and a number of them died. But finally they reached Lagos. As they were suspected of bringing epidemic diseases, they had to undress, and came ashore wrapped only in sheets issued to them by the British 
customs officers. Lagos and its closest surroundings were by then a British possession.

But soon they were met by other Afro-Brazilians who were already there, and so the story becomes one of the family group's absorption into this community of immigrants and the society surrounding it. Old Catarina has a chance to return to Abeokuta for one last visit, and then dies after just a year in Lagos. From there on, The Water House becomes Mariana's story-Mariana, Catarina's granddaughter, is thirteen as she disembarks that ship from Brazil, with her grandmother, mother, and siblings. It is also a story of a West African coastal society, where borders seem rather blurred.

The family does variously well. One sister marries a local man from Ibadan. But this man drifts away to become a preacher, perhaps goes slightly mad, preaches to beggars in the Lagos streets, ages quickly, and dies. (Street preachers keep appearing in Nigerian fiction as exemplars of liminality-see, for example, chapter 9.) One brother goes to England, and returns with an English wife. The young woman bears a son, tries her best to adapt to Lagos life, but becomes sickly and returns to England, where she dies. The widower brother later goes to Bahia to start trading, importing kola nuts and palm oil from West Africa to Brazil. He marries again there, and returns home with another wife. His half-English son from the previous marriage grows up in part in England with his maternal grandfather, but the latter decides that wartime England is too dangerous, and comes with the boy to live in Lagos.

Mariana herself soon demonstrates entrepreneurial talent. She marries Sebastian, another Afro-Brazilian (with some concern that Lagos husbands often take several wives), and becomes a mother. But while her husband goes off for work on Fernando Poo, the Spanish island colony further to the east in the Gulf of Guinea, she notes the freshwater shortage in Lagos, has a well drilled next to her house, and starts selling water; this becomes the original Water House. And so a small business empire takes off, soon branching out into other trades.

Sebastian returns, but is no longer much good at anything and gets killed as he tries to settle a street brawl. Yet, before that, he and Mariana have made a journey westward along the coast, finding more AfroBrazilians just about everywhere, even as the land is divided between different European empires. The Germans are there more briefly than the others, in Togo, but lose their overseas territories in World War I. So they are gone. The Portuguese maintain a more durable, but minimal presence: the fortress enclave São João Baptista de Ajudá, 
there since the days of the slave trade, on the shoreline of what was otherwise the French colony Dahomey. But the handful of Portuguese still running the place are on good terms with their varied neighbors, and Portuguese wines are treasured, along with cachaça, the distilled sugarcane liquor coming over with ships from Brazil. Most of the other Europeans on the West African coast, of course, are Englishmen and Frenchmen.

A personal parenthesis here: in the early 1960s, as I traveled by road along the West African coast, I passed São João Baptista de Ajudá. By then, a couple of years had passed since the newly independent republic of Dahomey had ordered the Portuguese to leave. The two remaining Portuguese gentlemen had marched out, after burning what was left of the fortress. By the time I came by, there were only ruins and a rusting car wreck.

Yet perhaps the departure of these two men marked the beginning of the end of the Portuguese empire? Later in the same year, Indian troops would invade Goa, the enclave in South Asia, and then, in the following decades, the Portuguese would lose everything: Angola, Mocambique, Guinea-Bissau, East Timor, and finally Macao, returning to China.

But back to Mariana, and her business acumen. Her journey with Sebastian takes her to Ouidah, at the western end of the Dahomean coastal strip, next to that Portuguese fortress. ${ }^{1}$ It is in that town she comes to establish her new headquarters, with the building of a new Water House. Next to Ouidah on the coast there is Zorei, a fictitious country invented by the author Olinto, but as such also a French territory for the time being. Ouidah itself offers a diverse scene. As she develops her business and her social ties, Mariana comes to know Seu Haddad, a Lebanese from Beirut, and the Frenchman Monsieur Casteller, a teacher, living alone. Later on, widowed, she occasionally shares a bed with him. Later on, too, some forty years after she left Brazil, Mariana reflects on her language experience:

She never managed to think in any other language but Portuguese, but she enjoyed talking in English and in French, in Yoruba and Ewe, even in German which she hadn't spoken now for such a long time. Seu Haddad's French, for example, had a charm all of its own, it was different from Monsieur Casteller's French, like the different Yoruba in Ijebu-Ode and Abeokuta, in Ifé and Pobé sometimes there were sounds in one that didn't exist in another. (Olinto 1970: 279)

In Lagos, in her youth, the encounter with English had come early. For one thing, in the Roman Catholic congregation, while Afro- 
Brazilians made up a large part of the membership, the services were in English. And that was because the priests, one after another, were O'Malleys and O'Tooles. (Indeed, Catholic church and missionary work in much of the British Empire seemed to be in the hands and voices of the Irish-priests and nuns. Given the ambiguous relationship between them and the British, one may perhaps speculate about what was their more secular message. Was there a little of an Irish empire as well? The last remaining European missionary in Kafanchan, when I was there in the 1970s, was indeed another Father O'Malley. ${ }^{2}$ )

Before her husband is lost, he and Mariana have several children, and with time they will move around in the world. Family gossip gets to be exchanged in large part by mail. One son goes to London to study law. When he returns, he is accompanied by a British friend, who also finds a job in Lagos. But Mariana finds out that the young Briton has come along because he has become infatuated with his Nigerian fellow student, and they are in a homosexual relationship. Mariana, wanting more grandchildren, makes it clear to her son's expatriate lover that she cannot accept that. Consequently the Englishman commits suicide by jumping out of a fourth-floor office window, and her son marries a nice Afro-Brazilian girl.

A daughter has also gone to England, to study medicine. Writing home, she can report, for one thing, about having seen snow for the first time. After completing her studies very successfully, she, too, comes back to Nigeria, where she eventually finds herself in charge of a hospital in Ibadan. And marries, rather late by local standards.

Mariana, for her part, is mostly in Ouidah, carrying on with business. Monsieur Casteller, the Frenchman, is recruited to give one of Mariana's younger sons language lessons, and then this son, named Sebastian after his father, goes off to Paris to study.

While all this happens in Mariana's family, there has first been a period of bad news from Europe, about the rise in Germany of a man named Hitler, and another world war. That, again, was why her brother's English father-in-law decided to take his grandson to Africa. But the war ends, and meanwhile, not least among African expatriates in both England and France, there is more and more talk about the possibility of Africa becoming independent in a not-so-distant future. In Paris there is the Présence Africaine movement. The prospect of independence attracts some people in the African territories as well, and when Sebastian returns to Africa-somehow, to that imagined land Zorei-he soon shifts from a teaching career to nationalist politics. Things happen quickly. The French have the idea of including politicians elected in their overseas territories in their national assembly in Paris. In real life, both 
President Leopold Senghor of Senegal and President Felix HouphouetBoigny of the Ivory Coast were there earlier in their careers. In Olinto's fiction, Mariana's son Sebastian is elected to go there, thus returning to Paris. But that arrangement would not endure. Soon he is back in Zorei, and elected the young independent country's first president. His wife-an Ewe girl from further west, whom he had met in Paris, where she was studying nursing - had died in childbirth, and so this president is a widower. For the Independence celebrations, Mariana has to slip over the border from Ouidah to serve as stand-in First Lady.

But her son's presidency will not last long. Rather soon, in a military mutiny, he is killed in his palace. (This event in the book seems modeled after the killing of President Sylvanus Olympio in Togo in early 1963Olympio was also of Afro-Brazilian background, and the first African head of state to become the victim of a coup.) Afterwards, the soldiers claim that it was not him they were after, but some of his ministers.

And around there ends Mariana's story. With all its family intricacies and multi-sited events, perhaps The Water House could have been turned into a long-running TV series. Again, the book is by a Brazilian author, and was undoubtedly aimed primarily at a Brazilian audience interested in a Brazilian diaspora. Most Afro-Brazilian families in West Africa hardly had so much recurrent contact with Brazil as did Mariana's (I have not referred to all of them here), and hardly as much other world travel either. London, Paris . . . ; what counts in Europe are the imperial capitals, although evidently no longer Lisbon. Another of Mariana's young Afro-Brazilian prodigies, also in Paris, frequents the cafés: he goes to the Café Flore and meets Sartre, and at a Montparnasse café he runs into Jorge Amado, who is surprised to find this African speaking Portuguese, and of a rather Brazilian variety. (Amado, of course, is the celebrated writer from Salvador-Olinto's readers would appreciate that.)

Yet Olinto shows a fair amount of local knowledge, not least about the Afro-Brazilians' on-and-off involvement with Yoruba religion, which of course has its immediate counterparts in their Brazilian homelands as well. Lagosians who still find the street signs for Bamgbose Street, running through what used to be the Brazilian Quarter, will perhaps be amused as they find that Olinto consistently has it as "Bangboshe Street." Most importantly, however, we sense that the coastal stretch from Togo, and actually beyond Lagos, to the Niger Delta, with its variety of large and small ports, was once a more organic unity-before Nigeria became Nigeria, and even into the twentieth century, despite those boundaries that came to be drawn by colonial powers. 
On visits to Lagos in the 1960s, I could see material evidence of the early Afro-Brazilian presence. There was still Brazilian architecture: two-story buildings, fading beauties with ornamental doorways and window frames and wrought-iron balconies. ${ }^{3}$ Mostly this would be lost in later years, replaced by new high-rises, never preserved as a World Heritage Site the way similar quarters were in numerous other cities. (Instead, Nigeria would later get its first such site in Osogbo-see chapter 6.) In the old cemetery in Ikoyi, I could also find such names as Pereira and da Souza inscribed on the gravestones.

Before I got around to reading Olinto's novel, I had also read the African American anthropologist Lorand Matory's (2005) historical ethnography of the Afro-Brazilian connections across the South Atlantic. The Black British sociologist Paul Gilroy (1993) had advanced the notion of a "Black Atlantic," but, in his version, it was largely a Black North Atlantic. Matory emphasized that there was a Black South Atlantic as well.

The city of Salvador has drawn a great many anthropologists over the years, from Europe as well as North America, but Matory is unusual in his attention to both the Brazilian and the Nigerian ends of the back-and-forth cultural traffic. ${ }^{4}$ It began, certainly, with the slave trade, when members of various African groups were shipped westward as merchandise, but in which one or two groups could leave a more enduring mark on what became Afro-Brazilian culture-not least in the syncretic religious forms resulting from the meeting with Catholicism. On a visit to Salvador in the late 1990s, I could buy a set of cards showing which Yoruba gods correspond to which Catholic saints, according to the local cultural translation.

But then, after slavery ended, the exchanges continued, as Olinto's story about Mariana and her family shows. The migrants from Brazil indeed settled along a stretch of the coast, but, on parts of it, conditions were a bit turbulent. One exception was the place where the British, the dominant maritime power, had established their main port: Lagos. Consequently this became the most attractive destination.

Some of the Afro-Brazilians came to go to school and learn English, on its early way toward becoming a world language, and then returned home. Others came back to Brazil with a renewed toolkit of ritual paraphernalia. But many remained in Lagos and in other cities nearby. A number of them were skilled in construction work and in crafts. Decorative tiles and porcelain were bought from Brazil, while kola nuts moved across the sea in the other direction. (Again, Mariana's brother was involved in this.) 
Who, however, were the people who were sent over as slaves to Brazil, like Mariana's grandmother Catarina, and who were the locals receiving the Afro-Brazilians when they came ashore again? We may be accustomed to think of Afro-Brazilian culture in Salvador as showing strong Yoruba traces, and to identify the people of Lagos and its large hinterland as Yoruba. Lorand Matory points out that things were really more complicated. Certainly there were a number of kingdoms, some large (such as Ife and Oyo), some small, showing cultural affinities as well as some variations. Yet there was, in an earlier phase, no real sense of shared identity. The Hausa people, pushing their way southward in the nineteenth century, referred to the people they would encounter there loosely as something like "yarriba," and it seems that label would come to stick.

In Lagos, too, there would not be only the Afro-Brazilians, the locals, and the British masters, but also the Saro, or Krio-the Sierra Leoneans who had likewise been freed from slavery and the slave trade, and came with some modern skills similar to those brought by the Afro-Brazilians. ${ }^{5}$ Many of them also had local historical roots. To a degree, the Afro-Brazilians and the Sierra Leoneans could be in competition (with the latter advantaged by their superior English language knowledge), but together they were buffers and middlemen between the locals and the British. And then the locals were changing. They went to mission schools and learned to read and write. You may remember that Olinto's Mariana reflected on the dialect differences between people from Ijebu-Ode and Abeokuta and Ife? That was between spoken forms of what could be taken to be Yoruba. Now, however, Bible translations, other religious texts, and other officially sponsored writings introduced a Standard Yoruba. Here, as in many places in the world, a shared language, in writing and print, could be an important foundation for a shared identity. ${ }^{6}$

Moreover, there were more British arriving, taking over jobs that had previously been held by Afro-Brazilians and Krio. Colonialist racism grew-and the response was a beginning African nationalism, with Sierra Leoneans, Afro-Brazilians, and local educated Yoruba forming a united front. Among the Afro-Brazilians, there was an inclination to assimilate-for example, shifting to Yoruba family names.

So, Lorand Matory concludes, the Yoruba collective identity is not some primordial, timeless thing, but one that has developed through political and cultural processes of amalgamation not so very long ago. By now, certainly, most Yoruba would not be aware of so much of this history. Yet one may sense that to a certain degree, the Yoruba identity is a product of early Afropolitanism, in its South Atlantic version. 


\section{Notes}

1. Early, slave-trading Ouidah shows up in many writings. Zora Neale Hurston's Barracoon (2018), published after lying around as an unpublished manuscript for almost eight decades, is based on an extended interview series with an old slave of Yoruba origin, brought from Ouidah on what may have been the last (and by then illegitimate) slave shipment on the vessel Clotilda, arriving on the coast of Alabama in 1859. See on this also chapter 19, note 4. Hurston, African American anthropologist-writer, would become prominent with later writings, published in the 1930s and 1940s. Another writer on Ouidah is the novelist and travel writer Bruce Chatwin, whose The Viceroy of Ouidah (1980) portrays a ruffian from the Brazilian wilderness turning into a slave trader on the West African coast, next to the old fortress. Moreover, Colson Whitehead's 2017 Pulitzer Prize-winning novel The Underground Railroad starts off at Ouidah, as the grandmother of the story's key figure is sold off into transatlantic slavery.

2. The presence of the Irish by way of the Catholic church may also have played a role in making the Republic of Ireland the destination of a considerable number of Nigerian migrants in the late twentieth century. For an ethnographic study of African, not least Nigerian, migrants to Ireland, see Maguire and Murphy 2012.

3. For one account of Brazilian-style architecture in Lagos and neighboring lands, see Vlach 1984.

4. Among the prominent anthropologists doing research in Salvador at one point or other in the twentieth century were Melville Herskovits, Ruth Landes, Roger Bastide, and Pierre Verger. We come back to Verger in chapter 11, and can see in chapter 19 that the linguist Lorenzo Dow Turner was also there. Note here, too, at the African end, the monograph by Kwame Essien (2016) on Afro-Brazilians in Accra, Ghana, and one chapter on those in Accra by Ato Quayson (2014: 37-63).

5. For a history of Sierra Leoneans in nineteenth-century Lagos, see Kopytoff 1965.

6. Matory notes that Benedict Anderson's classic Imagined Communities (1983)-referred to in the introduction-has been a major source for the understanding of a shared print language as a major basis of nationalism.

\section{References}

Anderson, Benedict. 1983. Imagined Communities. London: Verso.

Chatwin, Bruce. 1980. The Viceroy of Ouidah. London: Jonathan Cape.

Essien, Kwame. 2016. Brazilian-African Diaspora in Ghana. East Lansing: Michigan State University Press.

Gilroy, Paul. 1993. The Black Atlantic. Cambridge, MA: Harvard University Press.

Hurston, Zora Neale. 2018. Barracoon. New York: HarperCollins. 
Kopytoff, Jean Herskovits. 1965. A Preface to Modern Nigeria. Madison: University of Wisconsin Pres.

Maguire, Mark, and Fiona Murphy. 2012. Integration in Ireland: The Everyday Life of African Migrants. Manchester: Manchester University Press.

Matory, J. Lorand. 2005. Black Atlantic Religion. Princeton, NJ: Princeton University Press.

Olinto, Antonio. 1970. The Water House. London: Rex Collings.

Quayson, Ato. 2014. Oxford Street, Accra. Durham, NC: Duke University Press. Vlach, John Michael. 1984. "The Brazilian House in Nigeria: The Emergence of a 20th-Century Vernacular House Type." Journal of American Folklore 97(383): 3-23.

Whitehead, Colson. 2016. The Underground Railroad. New York: Doubleday. 


\section{CHAPTER 3 \\ Igbo Life, Past and Present \\ Three Views}

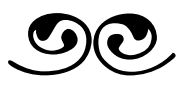

The hero, the ultimately tragic hero, is Okonkwo. For one thing, Okonkwo is motivated by a struggle not to become like his father. The latter had been a weakling, happiest when he was playing his flute, sinking further and further into debt. Okonkwo himself is recognized very early as a champion wrestler. He fights well in the recurrent intervillage skirmishes, and he runs his household (with several wives) efficiently, although perhaps rather brusquely. So far, a success story-but when by accident he kills a man from his own village, Umuofia, he has to go into exile, for seven years, with his entire household, in the village of his mother. Building up his life a second time, in a strange place, is no real pleasure.

Until this time, the only white man anyone in this part of Igboland has seen is the local leper, and that is another kind of whiteness. Now one shows up, entirely a stranger, with a small entourage of black people-some Igbo but speaking another ridiculous dialect; some from elsewhere. They reject the Igbo pantheon and praise another god, whose family sounds rather weird. Even so, the newcomers are allowed to stay on. Moreover, some villagers find their preaching rather appealing. One of these is Okonkwo's eldest son, who perhaps is turning out a bit too much like his grandfather, that family failure.

The first missionary to settle in Umuofia takes a rather open-minded stance, entering into dialogues with local elders about matters of belief and practice, learning a great deal but therefore also teaching more persuasively. Since there are advantages for the young people coming to his school, his flock continues to increase. He tries to engage with Okonkwo as well, but this leading villager, now back in Umuofia, refuses any contact. Then the missionary falls ill and has to leave. His successor is not such a gentle type. Furthermore, there is by now 
not only the more or less soft power of the missionaries, but also the governmental authority of a white district commissioner.

The village has become quite deeply divided. Okonkwo and some number of other senior figures try to put up resistance to the alien establishment, and the district commissioner requests that they come in for a discussion - but then they find themselves under arrest, handcuffed. The village has to pay a fine to have them released. The native messengers working for the foreign power are arrogant, hard people. Freed again, Okonkwo retrieves his machete and, in a confrontation with one of them, cuts off his head. Realizing that the inevitable punishment for this deed will be death by hanging, he then prefers to hang himself. Finding this dead body, the district commissioner orders it disposed of, and reflects that he now has yet more material for the book he plans to write, with the title The Pacification of the Primitive Tribes of the Lower Niger.

Okonkwo's story, of course, is the story the young Chinua Achebe tells in Things Fall Apart. This was the first indisputably successful Nigerian novel-if you see The Palm-Wine Drinkard as more controversial, at least to begin with-and it has remained an international classic. Published in 1958 as independence was near, it could help put a parenthesis around the colonial period. The white aliens appear only about twothirds of the way through the book, so it could provide an inside view of a precolonial society drawing to a halt; by the time it appeared in print, the district commissioner and his aliens were on their way out. It showed the author's mastery of the writer's craft, in the world's dominant language. Even the title's allusion to Yeats helps make the point. At the same time, as the story moves forward, it is embedded in what anthropologists have referred to as "thick description": through metaphors and all, it offers a rich sense of culture. "Among the Ibo the art of conversation is regarded very highly, and proverbs are the palmoil with which words are eaten."

As it turned out, Things Fall Apart would remain the most famous novel so far to come out of Africa-indeed, the Great Nigerian Novel. In 2018, sixty years after its publication, a Wikipedia article could inform us that Things Fall Apart had sold twenty million copies and been translated into fifty languages. A "critical edition," edited by Francis Abiola Irele (2009), with the novel itself occupying the first 117 pages, runs to nearly six hundred pages, mostly interviews, commentary, and responses. ${ }^{1}$ One literary scholar (Newell 2006) has raised the question "What if Things Fall Apart had never been published?" (Counterfactual questions, with all their diversity of possible answers, never cease to appeal to the imagination.) I used Things Fall Apart myself early in 
an "Introductory Anthropology" course, to give undergraduates a vivid sense of how a culture foreign to them could feel from the inside. And I know that a lot of anthropologists, in many places, have used it in the same way.

But considering all this, there is a certain quandary involved in saying something about Things Fall Apart here. One could hardly write a book about Nigerian literature, with commentary on Nigeria's past and present, without adequate recognition of the role of this novel in African literary history. Yet it has drawn so much scrutiny over a half century or so that it is difficult to add anything new.

What I will do, then, is to remind readers that there has been more to Chinua Achebe, both in the years more directly following Things Fall Apart and then for decades after. And I will place it alongside two other brief books, of different kinds, by Igbo writers who were almost Achebe's age-mates. Achebe was born in 1930. Dilim Okafor-Omali, author of A Nigerian Villager in Two Worlds (1965), was born in 1927. It is not quite clear when Victor C. Uchendu, author of The Igbo of Southeast Nigeria (1965), was born, but at least in that book he states that it was also in 1930.

Chinua Achebe's 1950s and 1960s novels have received very unequal attention, with Things Fall Apart obviously far ahead of all the others. That is a little unfortunate, as the later books have much to offer as well with regard to understandings of Nigerian society in different periods. Arrow of God (1964) portrays Igbo society and Umuofia at a later point, with colonial routines well-established, developing into tensions, misunderstandings, and the exercise of everyday micropower on both sides of the divide. Captain Winterbottom, "Wintabota" in local parlance, district officer, passed over for promotion several times, detests his superior several levels up, so he mutters, "Shit on the Lieutenant Governor!" Ezeulu, village elder, resists the pressure to become a "warrant chief" merely to help underpin the shaky version of indirect rule improvised to fit in Igboland. Precisely how much real historical knowledge Achebe could have of such matters may be difficult to determine, but his descriptive fiction seems plausible. There will be a little more about the colonial encounter in the next chapter, from British voices, and also below, drawing on Okafor-Omali's book.

Then there is Achebe's portrayal of the complexities of life of a young been-to, in No Longer at Ease (1960). I come to that in chapter 7. After that, Achebe's personal and professional life was to a great extent enduringly shaped by the Biafra War and its aftermath. There will be more about that in chapter 15. But that is still not all, for he stayed forever productive along many lines, in varied contexts. For one thing, 
I enjoyed the little book Hopes and Impediments (1989), a collection of articles and lectures, originally for audiences in three continentsone lecture at Dartmouth College, another in Sokoto, religious capital of the Nigerian Muslim North. Here is the literary and cultural critic Achebe, an established cosmopolitan, in a mostly relaxed and reflective mood, commenting for one thing on the work of other writers: Joseph Conrad (whom he insists on seeing as a racist), Amos Tutuola (with whom he sympathizes), and James Baldwin (whom he admires).

The son of a Christian evangelist father, Albert Chinualumogu Achebe was on a straight path toward more modernity from the very beginning. As a young nationalist, he dropped his first name and the latter half of the second, to become only Chinua. From a wellknown college in Umuahia, he headed toward academic life in Ibadan. Dilim Okafor-Omali was also a child of a new, colonial age. He was born in Port Harcourt, a new urban center arising in the Niger Delta swamplands, with a population coming together from here, there, and everywhere, and where his father worked at the post office. His first language was really Pidgin English: "Till I was five years old, I could not say a word in my mother tongue" - that is, in an Igbo dialect.

Parenthetically, one may find something interesting in the name uses of the three writers on Igbo life we are dealing with here. For Dilim Okafor-Omali, his father sought out the name Sigismund, "Conquering protection," and it seems as a boy he was mostly called "Sigis." But then the culturally alien name somehow disappears, like Achebe's "Albert," and only Dilim is left-short for Dilinyelum, "Be with me." On the other hand, Victor Chikesie Uchendu, who would have an extended academic career abroad, chose a more American style: Victor C. Uchendu, with a familiar first name plus an initial. But his book at one point reveals that he was Chikesie, "May God create well," at home when he was a child.

Okafor-Omali grew up away from his family homelands. By the early 1950s, he was a clerk in Lagos, and this is when he met a British historian, P. E. H. Hair, who was at the time at University College Ibadan and interested in the development of Enugu as an urban center. Hair, probably for an extended period Okafor-Omali's on-and-off mentor, has a brief introduction to A Nigerian Villager in Two Worlds, where he notes that the book had gone through several drafts. The version that was finally published, after a decade or so, had been written when Okafor-Omali was going to college in London.

That "villager in two worlds" around whom Okafor-Omali's account revolves, however, is not Dilim himself, but his father, Nweke. By way of a pencil-and-paper calculation of seasonal harvests and village 
market weeks, the son and the father conclude that Nweke would have been born in June or July 1898. That would suggest that the very real Nweke would have been a little boy at the time when Achebe's fictional Okonkwo commits suicide. While-after leaving Port Harcourt-he would become a village postmaster, his childhood and youth were in a more traditional Igboland, in an earlier cultural era. His father had died when he was only three years old, but his mother and his uncles raised him in the family homestead. Dilim and Nweke would later write down an eight-generation genealogy, until then stored only in collective memory.

Things really began to change in Nweke's life when the white people arrived. Well, to begin with there was only a single white person:

About two hundred Africans in hats, shorts, puttees and red tunic coats, buttoned to the waist, their brazen guns shining under the tropical sun-these were the soldiers of the white man. In the rear followed the carriers, whose only duty was to carry the loads. The white man, who was the Commander, was carried in a hammock. People said he had no toes, and rightly so, for he wore shoes. (Okafor-Omali 1965: 73)

There would be more of them, however, and more locals working for them. One villager took Nweke away to go to school, and so he was on his way to a career. It would take him to Lagos for further training, and then to that post office in Port Harcourt. The journey to Lagos would first involve a boat trip across the River Niger, the first time he traveled in any manner that was not by foot. Then he continued by lorry. He actually found Lagos rather disappointing. There was wealth, but also squalor.

Back in Igboland, there may have been fewer intervillage conflicts in the old style, but there were new tensions of other kinds: between Christians and non-Christians, and here and there between followers of different missions, Anglicans and Roman Catholics. On one occasion, Nweke found himself mediating locally between these. Most importantly, there was strong dissatisfaction with the warrant chiefs. OkaforOmali's discussion of their rise and fall more or less matches the story Achebe tells in Arrow of God. The warrant chiefs were too often men who had simply been adept at cozying up to the local representatives of the occupying power, and then became its stooges-quislings, to use a term from another part of the world. They could use their power harshly, from positions without any basis in traditional understandings of legitimate authority. At the same time, they could be suspicious of people who had been to school, as these could become leaders of the opposition. ${ }^{2}$ 
Indeed they had reason to be. Okafor-Omali portrays the rise among the Igbo of local improvement unions, typically with two bases: in the town or village home, but also wherever there were people from that place, somewhere else in Nigeria, in the diaspora. They could help each other where they had moved, but they also worked together to improve that home, with regard to infrastructure, schools, and other things. In addition, Okafor-Omali said, they could put pressure on the local colonial officers to fire the warrant chiefs, and allow power once more to come from below, by way of the new unions. In the case of his own town, in 1945, support for the grassroots political reform came even from those distant townsmen who were serving the British Empire as soldiers in Southeast Asia, at a time when World War II was coming to an end. (More about such "Burma Boys" in chapter 14.)

By then, however, his father Nweke was no longer there to participate in the struggle. He had died the year before, at what one could think of as the rather young age of 46-yet it had already been a life rich in historical experience. In a late letter to someone in the family, he had asked that Dilim should not be told of his serious illness, so as not to worry him; the teenage son was away in grammar school, in Abeokuta. Some twenty years later, as the son would publish his version of his father's story, he would end it with a plea for a new nation founded on village traditions.

After telling that story (drawing occasionally on other sources as well), Okafor-Omali apparently continued his life as a civil servant. Not much seems to be known about his later years. About Victor Uchendu, it turns out, it would be possible to hear more, to the very end.

Again, Uchendu was of just about the same age as Achebe, although his precise birthdate was apparently uncertain to himself as well. But his life path was quite different from those of Achebe and OkaforOmali, both born into versions of local modernity. His rather remote home village was Nsirimo. Uchendu's maternal grandfather, in another village, was reputed to have had a hundred wives. By the time Victor got to meet him, there were supposedly around thirty. Victor's mother, to begin with a divorcee and a refugee from her village of origin, and accepted only hesitantly in her new family, for her part became a very successful trader. She acquired several wives of her own, younger women who would assist her in her business. Igbo understandings of the varieties of marriage were at this point clearly not quite the same as what they had become in Okafor-Omali's and Achebe's families.

It was not at all obvious that Victor would proceed very far in schooling. After he finished grade school, he could not afford proceeding to high school, so he taught grade school himself for five years. Then 
he was admitted to a teachers' training college, and after that taught for a while in a high school. He served as secretary, too, of the Nsirimo Improvement Union, which met twice a year-the kind of association also described by Okafor-Omali.

After that, however, he came to the university in Ibadan, and discovered his future vocation. "I realized that I had been an ethnologist without knowing it." Now that he knew, he went on to the United States as a student, and became a professional anthropologist, getting his doctorate at Northwestern University, just next to Chicago. ${ }^{3}$

As long as anthropology was a discipline populated largely by Europeans and Americans, the convention was that field research should be done in a group other than on one's own. For the British, French, Dutch, Belgians, and Portuguese, this usually meant somewhere in their respective overseas empires; for the usually white North Americans, with American Indians. But occasionally, when students from somewhere in those empires showed up, they could become exceptions to the rule. They became pioneers in what would later be called "anthropology at home." Thus Jomo Kenyatta, later president of Kenya, and Kofi Busia, later prime minister of Ghana, got their higher degrees in anthropology in Britain on the basis of research in their own societies.

One might have expected that this would become the case with the young Nigerian Victor Uchendu as well. But his professors stuck to the overall rule of cultural boundary-crossing. So there he was, under the high skies of the plateau lands of the American Southwest, in his Igbo robes when the weather permitted in order to emphasize his foreignness (his professors suspected that his hosts were prejudiced against American Blacks), trying to make his way into a reservation society of Navajo Indians. He was actually one in a continuous line of ethnographers there, identified among his hosts as people "who run around asking questions about old ways" (Uchendu 1970).

For a while, we could conclude, Uchendu was connecting to at least three cultures: contemporary Igbo, mainstream American (including the academic variety), and Navajo-there is no sign that he was much involved with Black American culture, although in his American student days that could also have been a possibility. But then, as he was concerned with Navajo migrant labor, he actually worked both on and off the reservation. Here, it seems, was another society where things fell apart.

Apparently he would not thereafter linger in anything like Native American studies. As far as overt academic activity was concerned, the dissertation work became a parenthesis, and it seems the dissertation was never published. When he became a professor at another Mid- 
western American university, his part in the division of labor was mostly in African studies.

Yet even before he got to his doctorate, Uchendu had pulled together his thoughts and his combined insider-professional knowledge of Igbo life in a short book of some one hundred pages, in a series intended largely for an undergraduate student readership. The Igbo of Southeast Nigeria offers another inside view of Igbo life. Here, he wrote, "the reader will be introduced to Igbo society and culture by one of its culturebearers who has been privileged to gather his data as a 'full participant' and tries to write as a 'man of science"' (Uchendu 1965: 4). There is a succinct overview of topics such as kinship and marriage; farming and trading; spirits, oracles and ancestor worship; and the sharing of kola nuts as a sign of hospitality. There is some discussion of domestic slavery, which, as so often in West African traditional society, tended to be slavery lite, but with some special attention to the cult slaves, the osu, which are viewed among the Igbo as peculiarly abhorrent. (Chinua Achebe gets back to them in No Longer at Ease.) As in so much commentary on the characteristics of the Igbo people, Uchendu notes that they are strongly achievement-oriented. Equality of opportunity, but not of end result, is a principle of the careers of title-taking, with their accompanying ceremonies.

Achebe's Okonkwo had been deeply involved with these. Remarkably, Uchendu in his book makes no reference to Things Fall Apart, although he must have been well aware of the literary success it had already achieved. But he does recommend Onuora Nzekwu's somewhat quasi-ethnographic novel Wand of Noble Wood (1963). More about Nzekwu in chapter 14.

The Igbo of Southeast Nigeria is competent, well-rounded, clear, and accessible; it is academically sophisticated for an author who was, we may remember, still a graduate student, but it is not very lively. One of the most vivid segments of the text, however, is about what he describes as transparency as a quality of Igbo social life.

The Igbo, according to Uchendu, washed their dirty linen in public. They dreaded any loss of face; their leaders should be accessible to all; secretive people were held in contempt; the host would demonstratively taste food or drink meant for the visitor.

One might sense that in the small-scale, face-to-face society of the past, the Igbo probably had a better chance to realize their value of transparency in the ongoing contacts of everyday life. Much of what they could want to know about each other was more or less immediately at hand. And yet Uchendu already implies that they sometimes had to struggle for it, and also to make a show of it. 
Then sadly, some forty years after this book was published, one finds evidence that real transparency did not always fare so well in the turbulent Nigerian society of which the Igbo had become a part. After many years in American academic life, Victor Uchendu returned to his country of origin, having turned into an Afropolitan, and joined the faculty at the University of Calabar, in the extreme southeast, not really in Igboland. Early in his campaign to become mayor of his hometown, in 2006, he was assassinated, and it seems the crime has remained unresolved.

\section{Notes}

1. In his book The Rise of the Igbo Novel (1978)—with its origins as a doctoral dissertation at the University of Wisconsin-Ernest Emenyonu discusses the origins of Igbo writing with their connection to Christian missionary activity, and the shift from writing in Igbo to writing in English, and then devotes one chapter to Cyprian Ekwensi and three to Chinua Achebe.

2. For a professional historian's discussion of the warrant chiefs, see Elizabeth Isichei's History of the Igbo People (1976: 141-150), generally an impressive source ranging from precolonial times to the early 1970s.

3. There were actually three other Igbo anthropologists active at much the same time as Uchendu. One was Chike Onwuachi, whom I enjoyed meeting at the first annual conference of the American Anthropological Association I attended, in Denver in 1965. He had much of his career at Howard University, in Washington, D.C., before retiring to his Igboland home. Onwuachi did not publish so actively. Another was Ikenna Nzimiro, undoubtedly the most noticeable on the Nigerian arena. Nzimiro had been a young political, anticolonial activist in the Zikist movement (a radical wing of the National Council of Nigeria and the Cameroons (NCNC) party, named after its leader, Nnamdi Azikiwe, "Zik") in the period around 1950, even going to prison for sedition. Then he went to Germany, earning a doctorate in anthropology at the University of Cologne, and from there he proceeded to Cambridge for another doctorate in the discipline. For a long time his anthropological writings remained quite conventional, along the lines he had learned in his European training. Then it seems that a world anthropological conference he attended in Chicago in 1973, with many radical anthropologists from different corners in the world attending, gave him a stronger impulse to return to his radical roots; from then on he quite consistently wrote Marxist anthropology. He was in Biafra during the war, working for its government, although he was not quite convinced that secession had been a good idea. In other periods he taught at the University Nigeria, Nsukka, and later at the University of Port Harcourt. The third was John Ogbu, who got his doctorate at the University of California, Berkeley, and remained there with a prominent career as an educational anthropologist until his death in 2003. Simon Ottenberg, an 
American anthropologist with extensive Nigerian research involvement, wrote a long journal article discussing the work of Nzimiro and Uchendu soon after they had both died (see Ottenberg 2007).

\section{References}

Achebe, Chinua. 1958. Things Fall Apart. London: Heinemann.

-1960. No Longer at Ease. London: Heinemann. 1964. Arrow of God. London: Heinemann. 1989. Hopes and Impediments. New York: Doubleday.

Emenyonu, Ernest. 1978. The Rise of the Igbo Novel. Ibadan: Oxford University Press.

Irele, Francis Abiola (ed.). 2009. Things Fall Apart: Authoritative Text, Contexts and Criticism. New York: Norton.

Isichei, Elizabeth. 1976. A History of the Igbo People. London: Macmillan.

Newell, Stephanie. 2006. West African Literatures. Oxford: Oxford University Press.

Nzekwu, Onuora. 1961. Wand of Noble Wood. London: Hutchinson.

Okafor-Omali, Dilim. 1965. A Nigerian Villager in Two Worlds. London: Faber.

Ottenberg, Simon. 2007. “Two Renowned Nigerian Scholars: Ikenna Nzimiro and Victor Chikezie Uchendu." Dialectical Anthropology 31(1/3): 11-43.

Uchendu, Victor C. 1965. The Igbo of Southeast Nigeria. New York: Holt, Rinehart \& Winston.

. 1970. A Navajo Community. In Raoul Naroll and Ronald Cohen (eds.), A Handbook of Method in Cultural Anthropology. Garden City, NY: Natural History Press. 


\section{Inland, Upriver with the Empire Borrioboola-Gha}

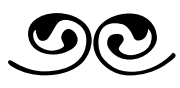

In the reputed phrasing of the real estate agent, what matters is "location, location, location." In the nineteenth century, when British colonialism began moving inland from the South Atlantic coast, Lokoja would seem to be all about location: a rather modest settlement, but strategically situated where the Niger and Benue rivers met. Howard J. Pedraza's small book Borrioboola-Gha (1961) is a chronicle of some of the early British involvement with what would become Nigeria, with Lokoja gradually emerging as a focus. Pedraza was British, and had been in the colonial service in Nigeria. The book does not explicitly say so, but a review of it in the Bulletin of the School of Oriental and African Studies (London) informs us that Pedraza had been a district officer at Lokoja for some years. Yet his book is largely based on historical sources and archival work.

The Niger-Benue confluence had been "discovered" (as one might Eurocentrically put it) by the explorer Richard Lander and his brother John, coming from upriver on the Niger, in 1830. The Landers had apparently come ashore at Badagry, another old Atlantic slave port just west of Lagos, and made their way overland to Bussa on the NigerBussa was where the earlier explorer Mungo Park had drowned in 1806. From there they did not have very far to travel on the Niger before they could see the other great river flowing into it. Here the Niger turned south. They continued down to the delta, reaching the sea.

Soon enough a Liverpool merchant launched a more sizeable expedition. This was McGregor Laird, son of a well-known ship-building family, who would have a major role in Niger River enterprises for several decades. That first expedition, in 1832, consisted of three ships; before making their way into the delta, they halted at Cape Coast, in 
what is now Ghana, and Fernando Poo-then a notable Spanish island base, by now part of Equatorial Guinea. (We saw in chapter 2 that Sebastian, Mariana's husband, also went there.) On the other hand, it did not go into Lagos-a major port for the slave trade, but not yet under British control. The journey upstream was hazardous, with a number of key crew members lost to malaria. Yet eventually, they could again see Benue and Niger meeting, the former clear and dark blue, the latter whitish and muddy.

Trading was slow. Cowrie shells were the only currency (as Amos Tutuola's palm-wine drinkard would also find in the Land of the Dead a hundred years later), and there was a dearth of those. Following various intermezzos, what remained of the first expedition returned to Liverpool.

It took Laird almost a decade to get a second expedition going, but now he had more official support. It was a complicated organizational construct, and some linguistic, cultural, and geographic confusion seems to have gone into both planning and execution. This time it was not all business, but a civilizing mission as well, carrying Bibles and other religious literature for distribution. There were also letters of recommendation from rabbis in London, just in case one would run into any Jews inland. One of the rabbis encouraged inquiries into the customs of the natives along the River Tigris; he must have gotten his great rivers mixed up. A German chaplain, the Reverend Schön, reputedly had some expertise in Hausa, the lingua franca further north, but on board, his sermons were "rendered unintelligible to many by his foreign accent."

More importantly, the crew included a young man named Samuel Ajayi Crowther, originally a Yoruba, who had first become a commodity for Portuguese slave traders. Freed by the British and landed in Freetown, Sierra Leone, to become a Creole, Crowther was placed in a missionary school and was found promising. After he was sent to Britain for even further training, he returned to West Africa, where he was recruited to accompany the Reverend Schön on the Niger expedition. After that, Crowther came back to England to be trained as a minister, eventually becoming the first African bishop of the Anglican church. But that is another story. ${ }^{1}$ (His grandson Herbert Macaulay became an early Nigerian nationalist.)

This expedition reached out for a treaty with "the king of the Ibo" (we may surmise that this was at Onitsha) to establish trading agreements and to abolish slave trade and human sacrifice. The king received a range of gifts supposedly from the Queen of England, and 
came aboard the main ship, where things seem to have turned a bit chaotic:

At the conclusion of the treaty, King Obie willingly accepted an invitation to join in prayers in the Captain's cabin, even to the point of kneeling in Christian fashion. Half way through, unfortunately, he became violently perturbed for the safety of his soul and at the end of the service, uttering a sudden fearful exclamation, he called loudly for his fetish to be brought so that he could pour a libation on the spot to his own gods. Perspiration streamed down his face and neck, and it was some time before he could be quietened with the assurance that the prayers were bilateral; when satisfied on this point, instead of pouring the libation he drank it himself and washed it down with some Spanish wine that was offered. (Pedraza 1961: 26-27)

If this expedition, too, had its problems, it received much favorable publicity in Britain. There were grandiose visions for future commercial development and continued philanthropic endeavors in the African hinterland. These in turn apparently inspired Charles Dickens's ironic fiction of a "Borrioboola-Gha" in the novel Bleak House: living in London, the small, plump, pretty Mrs. Jellyby is entirely consumed by the project of resettling impoverished Englishmen among Africans in the new settlement, where they would all grow coffee together. In support of this vision, both she and her daughter spend all their time sending out propaganda and answering queries about BorrioboolaGha, while their family life deteriorates, and the ignored Mr. Jellyby gets close to suicide. Unfortunately, in Dickens's version, the entire project fails, as the local African king sells the volunteer migrants into slavery so he can buy rum. And the Jellyby daughter, tired and exasperated, bursts out: "I wish Africa was dead! . . . I hate it and detest it."

This was the entry of Nigeria, or what would become Nigeria, into British fiction.

Yet more upriver traffic followed. By the 1850s and 1860s, the colonizing process seemed to stabilize somewhat. The prophylactic use of quinine against malaria had been discovered, so West Africa was no longer quite so surely "the White man's grave." But there were also more African hired hands, often liberated in the struggle against the slave trade, and familiar with the foreigners' ways of doing things.

Now, in 1860 it seems, Lokoja came into being as a commercial settlement at the Niger-Benue confluence, under the relatively longterm supervision of another colonial visionary: William Balfour Baikie, naturalist, philologist, and medical doctor. The community attracted 
people from surrounding areas, many of them apparently refugees from slavery, and its market place drew much trade. While running Lokoja with a firm hand, Baikie also found time and energy to translate Christian texts into Hausa and Nupe. However, his health suffered, and the time came to leave. Pedraza (1961: 64) concludes that "his long years of autocratic independence had made him irritable and cantankerous, and it is quite possible, though not a pleasant reflection, that he had become unbalanced." His replacement in Lokoja arrived. On his way back to Britain, Baikie made it only to Freetown, where he died.

By then McGregor Laird was also dead since a few years back, and British policy toward West Africa turned rather Dickensian and distracted. There was, for a period, no enthusiasm in London for pushing inland in this part of the dark continent. Such development as there may have been at Lokoja was at quarter-speed, depending more on local dynamics than on official long-distance support. Baikie's successors had the title of consuls, but one skeptical visiting trader referred to their residences as "Her Majesty's Mud-Huts."

Later yet in the century, however, there was George Taubman Goldie, forcefully running the Royal Niger Company with a close connection to the Crown, and so Lokoja came alive again. There were new facilities for trade, and after Goldie arrived in person for a visit to the region to wage a battle against the forces of the emir of the Nupe, it was clear that British power in the area would be durable. This was further manifested when Frederick Lugard, as new representative of the British Empire, took over something now described as the Protectorate of Northern Nigeria, on the Lokoja parade ground on 1 January 1900.

In the twentieth century, finally, Lokoja took on the form of colonial logic. The European population, which reached its record size of eighty-nine in 1907, lived in its segregated residential area of what was referred to as "Lugardesque" bungalow architecture, while the old neighborhood from Baikie's time became the native township. The young men working for what had been the Royal Niger Company, and was now the United Africa Company, were under the discipline of their manager, who kept their whisky bottles in his cupboard and allowed them "one tot per evening."

Pedraza's account ends rather ironically. "Location" turned out not to be everything; at least not Lokoja's. The site was not very healthy, compared, for example, to Kaduna, Lugard's new urban center. Soon enough, moreover, transport would be on new railways and roads, rather than by river. By the time Pedraza published his book, at the time of Nigerian independence, a hundred years after the town came into existence and sixty years after Lugard's appearance on its parade 
ground, Lokoja was once more a backwater. Yet moving forward again, to the twenty-first century, it does not seem to do so badly. Nothing, it seems, can stop a Nigerian urban center from growing. The river confluence may not matter so much, but with a population approaching a hundred thousand, the city is now a state capital and has a new university.

But back to Howard Pedraza: the review in the Bulletin of the School of Oriental and African Studies concludes that his book "will be useful to African schoolboys and undergraduates" (Jones 1961: 180). Again, it is not really an account of his own Lokoja experience, but rather the work of a district-officer-turned-historian.

In a history of writings about Nigeria, or what would become Nigeria, Chinua Achebe (and some other authors, such as Dilim Okafor-Omali) can offer the perspective of the colonized. Someone like Pedraza gives us the colonizer's view-from sometime between the mid-nineteenth century and the mid-twentieth century. Pedraza gathers materials from early colonization, while other writers provide autobiography, or glimpses of autoethnography, or even fiction. With the coming of Nigerian independence, the Afropolitan horizons of the colonialist veterans become views in the rear-view mirror. As a whole, this chapter is about such expatriate colonialist commentary-leading finally into a bit of oral history.

Pedraza goes back to earlier history. It so happens, however, that in a book describing some twenty years of service to the British Empire, one of his predecessors in Lokoja devotes a few pages to his own brief stationing there, in 1938-39. John Morley (1992: 80-85), coming in from previous postings further north, found that "the town councillors were a cantankerous lot, by and large, and did not respond to the mild joke or witticism which so often saved the situation when one was dealing with Hausas."

His main project in Lokoja was building the town's first public latrine. Where? To keep the foul smell at a distance, he had decided to place it away from other buildings, close to the river shore. That was fine, except for the two or three weeks of the year when the river flood peaked, and the latrine was out there in the water. Unfortunately, that was when Morley's superior officer came on tour.

But Morley soon moved on, for service elsewhere in Northern Nigeria, Eritrea, Malaya, Singapore, and finally in the Gold Coast, just before it became Ghana. Another paragraph of his West African reminiscences might be worth citing: the Elder Dempster Line mail boats, between Liverpool and main West African ports before World War II, "were an extension of the West African scene ... the passenger 
list was predominantly male, and the seasoned coasters were, even before the ship had cast off from its down-river berth, settled in front of gins and bitters in the smoking-room chairs they would hardly vacate for the rest of the voyage."

In fiction, from around this time, there is Joyce Cary's Mister Johnson (1939), finding a wider audience rather slowly_but also one of those books the young Chinua Achebe read, and disliked (together with Joseph Conrad's The Heart of Darkness, another colonial-era novel, not uncritical of colonialism, and yet not free from prejudice). The imagined young Nigerian Mr. Johnson, working in the colonial service in an area that is not his own, finds himself in an uncomfortable inbetween position, and faces the different personalities and styles of his British superiors. Of Irish-British family background, Cary had had his own mixed experience of serving in the colonial administration for some years around 1920.

On the whole, local-level colonial administrators have not contributed a great deal to published writing about Nigeria. ${ }^{2}$ Achebe's fictitious Captain Winterbottom in Arrow of God showed no sign of such plans. One notable exception is Stanhope White, with his book Dan Bana (1966). White joined the colonial service in 1936, but declined an appointment in Kenya, as he foresaw that the relationship between the Kikuyu people and the European settlers would only get worse-indeed, the result would be the Mau Mau rebellion. Instead he came to Northern Nigeria. His book offers snippets of Nigerian history, and much description of local life from his various postings over an eighteen-year period-from Maiduguri via various Hausa emirates to Tivland on the Benue. But not least revealing are his forthright revelations of the tensions between higher-level bureaucrats and the "Bush DOs" (district officers) like himself, where he could even be seen as a whistleblower. He comments ironically about one governor's circular announcing that "promotion to the higher posts lay only through the Secretariats; the ability to deal with paper was apparently of much greater importance than the ability to deal with men." His oppositional stance took him to what he recognized as a punishment posting: Birnin Kebbi, capital of the Gwandu Division, was in most ways not a bad place, but it was hardly unknown to the central administration that it was intensively plagued by mosquitoes. Stanhope White and his wife, who had come to join him, had to spend much of their time fighting them.

White-his Hausa nickname "Dan Bana," he notes proudly, means "he who is up to date"-did not remain in Nigeria until the coming of independence, but returned to Britain for a business career. When 
over a decade later he got around to finishing his manuscript, it was the beginning of 1966. The first military coup had just occurred, and he saw dark times ahead for Nigeria.

Those who wrote their memoirs, or had their biographies written by others, were otherwise mostly high-level people, of gubernatorial rank or so. One example would be Sir Rex Niven's Nigerian Kaleidoscope (1982). Niven ended his career when colonialism came to an end. In the final years, he had been close to the new Northern regional government under Ahmadu Bello, the Sardauna of Sokoto. He got along well with the aristocratic Sardauna, although on the whole one gets a sense, in an account with a flavor of imperial nostalgia, of members of a colonialist establishment engaged in their own encapsulated lives. The high point of Sir Rex's career was the visit of the young Queen Elizabeth.

More at a grassroots level again, but by a nonofficial, is Raymund Gore Clough's Oil Rivers Trader (1972). Clough came into his business when "oil" in the Niger Delta was still palm oil, not petroleum, and when the European traders were moving from rather anarchic conditions into somewhat more orderly colonialism. For one thing, there is an eyewitness account of the Igbo women's uprising in Aba in 1929, and the violent British response-one of the sordid moments of colonial Nigerian history.

As the 1960s and 1970s discourse shifted to "developing countries" and "international aid," there was evidently some disappointment among repatriated excolonial officers that their acquired local knowledge did not seem to count. They had become had-beens, reverse been-tos of a kind. But whatever the old local administrators felt about this back home in Britain, much of their reporting, handwritten or typed, was by then in the far-away archives-where I found it.

As I was doing my field research in Kafanchan, I made occasional side trips to Kaduna to look at historical documentation available in the branch of the National Archives located there. The colonial period only a couple of decades away, and Kafanchan being a quite young town, I could connect the reporting in the archives to the memories I was getting from old-timer townspeople. While in the archives, too, I listed the names of the district officers who had written the reports. Fairly soon after, when I was spending a term as a visiting scholar at a British university, I got in touch with a couple of them, by way of the government agency responsible for paying the pensions of the former colonial personnel. And I arranged to meet with each of them.

They had both spent a few years each in Kafanchan in the 1950s. This had hardly been a prestige placing, so my two informants had been rather young when they got there. One of them had remained long 
enough in Nigeria to spend a period higher up in the administrative hierarchy, in Kaduna-and he had also married the daughter of the next-to-last British governor there. (Of the other officers on my list, one who had been in Kafanchan before them had had a better chance for an extended career in the empire, ending it as governor of the Seychelles and becoming a peer. ${ }^{3}$ )

The old DOs excused themselves at first, saying I could really not expect them to remember much. Since I had been recently in Kafanchan and knew their reporting, however, I could refresh their memories, and they were soon reminiscing about the people they had written about-some of whom were among my own acquaintances.

The office/residence of the district officer had been set a little apart from the African town. It was approximately midway between the Catholic mission and the railway housing. As the few white people in Kafanchan at the time would belong in one or the other of these, said one of my informants with a smile, this led to a certain balance in interactions. Clearly the railway people were considerably more profane. In a village further away, there was the station of that North American, evangelical Protestant mission that was most successful in the area. The headstrong veteran head of that mission, much longer in the area than any district officer, was clearly often a bit of a nuisance. So was the aging Hausa emir of Jemaa, head of the "native authority," preferring to stay out of the way of the white men, but rather unpredictable and inconsistent in whatever decisions he was supposed to make.

But both the old DOs really became most enthusiastic when they had a chance to reminisce about their own pet projects in and around Kafanchan. One had started a football cup-the railway workers had a team, the teachers another, and so forth. The other had made villagers make clearings for improved roads, and then made funds available for local contractors to build small, simple bridges where needed. (Preferably at right angles to the road, so one could not cross them at too high a speed.)

What, then, did these two men now do, back in the mother country? One of them worked in local government. The other I met in his tiny office in Bush House, the old broadcast building in central London, where he was in charge of BBC Hausa news; the empire might be a thing of the past, but the public service company was still in touch with distant listeners. Before he found this job opening, he had briefly taught school.

In different ways, perhaps both could use some of their Nigerian experience. But they hardly had the opportunities for their own initia- 
tives and priorities they had had as district officers in charge of an area with tens of thousands of inhabitants, alone and far from their superiors. It was obvious that they now saw their stay in Kafanchan as a rich period in their lives.

It was another aspect of those lives, too, that they did their part as local ritual engineers. One of them reported to Kaduna about how Kafanchan celebrated the coronation of Queen Elizabeth. And then there were the annual festivities of Empire Day. In these small ways, perhaps, they had been contributors to that border-crossing Afropolitan imagination.

\section{Notes}

1. For a brief account of Crowther's life and work, see Apter 1992: 193-204.

2. An anthropologist, Helen Callaway (1987), has drawn on varied materials, including interviews, in assembling a view of expatriate women in colonial Nigeria, providing a sense of ambiguities, ambivalences, and recurrent absurdities in their lives, in large part as spouses of colonial officers.

3. This was Sir Bruce Greatbatch, who became controversial in his period on the Seychelles when he arranged the deportation of Indian Ocean island inhabitants from what would become the American naval base of Diego Garcia.

\section{References}

Apter, Andrew. 1992. Black Critics and Kings. Chicago: University of Chicago Press.

Callaway, Helen. 1987. Gender, Culture and Empire. Urbana: University of Illinois Press.

Cary, Joyce. 1939. Mister Johnson. London: Michael Joseph.

Clough, Raymund Gore. 1972. Oil Rivers Trader. London: Hurst.

Jones, D. H. 1961. Review of Borrioboola-Gha. Bulletin of the School of Oriental and African Studies 24(1): 180.

Morley, John. 1992. Colonial Postscript: Diary of a District Officer, 1935-56. London: Radcliffe Press.

Niven, Rex. 1982. Nigerian Kaleidoscope: Memoirs of a Colonial Servant. London: Hurst.

Pedraza, Howard J. 1960. Borrioboola-Gha: The Story of Lokoja. London: Oxford University Press.

White, Stanhope. 1966. Dan Bana: The Memoirs of a Nigerian Official. New York: James Heineman. 


\section{CHAPTER 5 \\ The City, According to Ekwensi ... and Onuzo}

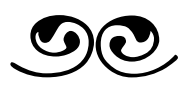

Cyprian Ekwensi was born in 1920-an Igbo, but already an exemplar of his people's outward mobility. His life began in Minna, a town in the Middle North on the railway. Later he spent a part of his childhood in Jos. A Wikipedia entry intriguingly lists his father's occupation as storyteller and elephant hunter. His early beginnings may explain the fact that in his large and varied body of writings, a fair amount deals with Northern Nigerian topics, such as Burning Grass and An African Night's Entertainment (both 1962)—both largely rural, with no Igbo visible.

He began to write in the 1940s for a variety of local outlets. A number of his books and booklets were intended for school use. At the same time, he made his living in other ways, in forestry and in pharmacy, in which he had some training. Then in the early 1950s, he came to Britain for several years. ${ }^{1}$ By the time I met him briefly in Lagos in 1961, he was director of information services, with his office in the center of Lagos, and seated behind a large desk, with a color print of the young Queen Elizabeth on the wall behind his back. This was in the brief period just after the arrival of independence when she was still Nigerian head of state; the country's presidency only came about in 1963.

He said he saw a certain danger in staying abroad too long, as one might get too impatient with things when one came home. By then he had just published Jagua Nana (1961). Before that, there was already People of the City (1954), published only a couple of years after Tutuola's The Palm-Wine Drinkard. This earlier book was dedicated to "West African Voices: a BBC programme." Some of his stories had been broadcast there.

With People of the City and Jagua Nana, Ekwensi made his reputation for portraying city life, especially in Lagos. In the first of them, he 
begins by declaring that the city "shall be nameless," but then the central figure, "a most colourful and eligible young bachelor," Amusa Sango, is a crime reporter with the West African Sensation, which is a Lagos newspaper in at least three later Ekwensi novels. Amusa Sango, however, is active on both the day shift and the night shift, as he is also a very popular dance band leader. (No wonder he needs his "houseboy," Sam, of uncertain age_- "He could be fifteen or fifty.") Hearing Amusa's music filtering through the neighborhood from the club where he is playing, irritated husbands would observe their wives "drop their knitting and sewing and wriggle their hips, shoulders and breasts, sighing with nostalgia of musty nights years ago." Early Nigerian fiction, not only by Ekwensi but by other male authors as well, tends to be strong on sensuality. ${ }^{2}$ That would also go well with Amusa's good friend Bayo: "Young, handsome, strong, idle and penniless: that was Bayo. You know him well. He's in your city, too. He's in every city in the world." Bayo, however, falls in love with Suad, a young Lebanese woman, perhaps in her late teens, working with her cloth-trader elder brother in his shop. Apart from the ethnic dimension of this courtshipLebanese men may accept the company of African women, but frown on unions the other way around-there is the complication that the newspapers are warning against a continued invasion of Lebanese and Syrian petty traders who push African traders out of business.

Amusa, for his part, and to begin with, is torn between two women. One is Aina, escaping from her marriage to a peasant in a village some sixty miles away, and greatly attracted to city life, surviving partly by petty theft, which at one point takes her to a brief jail sentence. The other is Beatrice, possibly even more attractive, married according to local custom to a British expatriate, with whom she has three children. But as the expatriate evidently has another marriage and family in his home country, there would seem to be no great future for Beatrice as his missus.

A third alternative turns out in the end not to matter so much. The West African Sensation sends Amusa to the East to report on the coalmine workers' strike, and the violent response to it by the colonial power (see a little more about this in the next chapter, in the section about Enugu). While he is there in the East, he makes an excursion to the convent school nearby to see the girl whom his aging mother has selected to be his wife. She is pretty in a sweet, innocent way, but he realizes that he is not attracted to her. More continually in the story is the greedy landlord Lajide, whose constant juggling with properties and rentals inserts itself again and again into the lives of Amusa and his circle. Although Lajide already has eight wives, he continues to 
be on the lookout for further possibilities. He makes some sort of deal with Beatrice, who becomes the manageress of the club where Amusa has been performing with his band-although by then he has terminated their employment. A little later, Beatrice joins up with Kofi, a truck driver more or less constantly on the road between Lagos and the Gold Coast, his home. At a point when Sango is down on his luck, Kofi suggests he should seek a new future in that hopeful country. Beatrice, on a last visit to Lajide, is beaten up by his remaining seven wives. The oldest one has recently died.

Meanwhile, Amusa runs into a second Beatrice, whom he saves from a difficult situation at a funeral service for the great nationalist pioneer De Periera (whose name sounds rather Afro-Brazilian, although Ekwensi's spelling may be doubtful), who has died at the age of eighty-three. This Beatrice is again extremely beautiful, but Sango must be disappointed when she tells him that her fiancé is a third-year medical student in Edinburgh. When he returns, and she has trained as a nurse, they plan to open their own hospital in the remote interior. The big city does not really need any more doctors.

Bayo, for his part, is about to have a hurried wedding with Suad, before her brother has a chance to fly her back to their country of origin to prevent that. But the brother shows up with a gun and kills both of them, before disappearing only to commit suicide himself. Amusa reports this complicated story, with its racial overtones, for the West African Sensation, but this becomes so controversial that his superior at the paper, an expatriate named McMaster, who had just recently offered to promote him, now fires him instead. At this point, neither the trumpet-playing night shift nor the journalistic daytime work are going well.

Toward the end of the book, Aina shows up again, telling Amusa that he is the father of the baby she is pregnant with. And then still later, a number of arrivals, departures, and deaths result in a rather different final cast of characters. But Sam the houseboy, the second Beatrice, Kofi the truck driver, the first Beatrice's expatriate commonlaw husband, and Amusa himself are all still there. The ending is happy and a bit unexpected.

People of the City offers a slice of lively urban imagery set in a time of late colonial transition. The lingering dominance of expatriates is resented, with the exception of a few who happen to have non-British surnames. Perhaps it surprises a little that Nigerian ethnic divides hardly draw any mention, but this may to some extent go with the gesture of keeping the city nameless. 
The story also includes a motif that recurs here and there in Nigerian fiction-the overseas significant other. This may be a loved one, yet to return to become a been-to; or a partner (more often a she than a he) who returned home after failing to adapt to Nigerian life; or someone who remained at home, one partner in what is understood to be a conventional marriage, while the other partner engages in transnational bigamy by way of a common-law union in Nigeria; or someone in working life, such as the editor at his desk in London or New York. There may be other varieties as well.

When we get to Jagua Nana (1961), Ekwensi's Lagos already seems rather familiar. Knees, armpits, breasts, shoulders, and thighs are all there already in the first paragraph. Jagua, or Jagwa, no longer so young, is so called not after the feline animal (which is not African anyway), but after the British prestige car. Good looks, stunning fashions. She likes to think of Freddie, a teacher who lives in the same house, as her young boyfriend. He continues reasonably studious, hoping to go to England for legal studies, and Jagua wants to support those plans-so he can then come back and marry her, after she is no longer attractive enough to draw other men. The difference between Jagua and Freddie becomes clear enough when he takes her along to a British Council lecture event (on "Some Personal Recollections on the Passing of White Imperialism in Nigeria"), where he joins all these other educated men in laughing in the right place at the lecturer's jokes, while Jagua just sits there bored. She walks out and heads for the Tropicana nightclub, where Freddie joins her a little later. But then he walks out. He cannot stand the mixed company of more senior men of varied West African (some already been-tos) and Syrian backgrounds where Jagua feels at home, with her experience of having been in the fashion business along the coast. (Accra was a center.) At this stage it turns out that there is actually a triangular drama. Freddie is getting more attracted to young, sweet Nancy. Nancy's parents are Sierra Leoneans, and Jagua used to do Nancy's mother's hair. Both Jagua and Freddie are Igbo, although as Ekwensi shows, in Lagos they speak Pidgin English to each other.

Somehow Freddie gets enough funding together to fly away to England and get started on more studying. Jagua goes out to the airport to see him off. To begin with, she gets a steady stream of letters from him, but after a while it slows down to a trickle. So she goes to a letter writer in the street, who helps her compose a letter to him.

Then the book turns out not to be purely a Lagos story. Jagua gets on a long-distance mammy-wagon for an exhausting journey east, even if 
she manages to claim the privileged single seat next to the driver. She goes first to see her elderly, ailing parents in a village near Onitsha; her father is a reverend. From there she proceeds beyond Port Harcourt, partly by canoe, to Freddie's home village, to make its acquaintance. It is a place with old, dilapidated houses in the Niger Delta area.

It comes as a bit of a shock to find Nancy and her mother already there. One early morning when Jagua goes down to the nearby stream for a bath, she finds Nancy already there. After a heated exchange, Nancy swims away-but is captured by young men from the hostile village across the stream. Feeling guilty, Jagua dresses up in her very best and goes over there to see the village chief. This is a middle-aged man of approximately Jagua's age, who has three wives, but he has never met anybody like this visitor before. With all her sophistication she has no trouble seducing him. He has Nancy released at her request, and wants to pay a bride-price to keep Jagua for himself. Jagua, however, prefers to return to Lagos. On her way, she makes a stop at Onitsha to see her trader brother, who wants her to remain and get busy in respectable commerce. But no, Lagos is waiting with the Tropicana, where Jimo Ladi and his Leopards are still playing.

Another sweet young man, Dennis, comes her way-but he turns out to be a member of a gang of thieves, who can use her as a fence for stolen gold. The police come to raid her rooms after a tipoff.

Then, however, there is also Uncle Taiwo, now and then at Tropicana, with loads of money and involved in party politics. Basically there are two parties, simply named Other Party One and Other Party Two-that is, OP1 and OP2. (Perhaps Ekwensi the civil servant does not want to come too close to more real-sounding party names here.) Jagua begins working with him for OP2, campaigning among market women. Things get more complicated when Freddie shows up again, having returned from England, with Nancy, now his wife (with two children), who had joined him there. Overseas, he had already joined the local branch of OP1, and now he is with that party organization in Lagos. The election campaign becomes very violent, and Uncle Taiwo and Freddie are opposing candidates for the same council seat. Dennis turns up again as one of the street fighters for OP1. Freddie is killed in a street battle between the parties, but, as public opinion turns against OP2 with this, Uncle Taiwo still loses the election, a personal disaster for him.

Jagua's life in Lagos has turned quite disorganized by the time her Onitsha brother turns up looking for her. Back in the village, their father is dying and wants a last encounter with his wayward daughter. They return there, but too late. He is already dead. While Jagua lingers in the village, a young woman who has recently been more or less her 
understudy in Lagos shows up with news from the big city. Dennis has been hanged for a variety of crimes. Uncle Taiwo's dead body has been found at a centrally located roundabout. So Jagua gets around to open a package with which Uncle Taiwo has entrusted her-and there she finds a very large amount of cash, in pound notes.

She travels back to Freddie's village once more, and finds that the village across the stream has been prospering under the progressive leadership of the chief who had once been her suitor. Without looking him up, she donates a considerable sum to education in that village. And then, becoming impatient with life in her parental village, she has her brother help her acquire a very good sewing machine. The last we see of Jagua, she is setting herself up to become a merchant princess in Onitsha.

At least initially, yet another city novel by Ekwensi takes us away from Lagos: Iska (first published in 1966, in paperback 1968) starts in Kaduna, the Northern city created as a modern, colonial-period regional capital by Governor Lugard. ${ }^{3}$ It begins with a Romeo-andJuliet story of ethnicity. The main figure, Filia, is Igbo, in her late teens, light-skinned and good-looking, just about finishing her education at a Roman Catholic convent school, a diaspora girl who has never lived in Igboland. The young man who spots her and seeks her out is a Northerner, a junior civil servant. They fall in love and expect a future together. But their personal encounter is set within the context of ethnic interrelations as they are in the mid-twentieth century, early postcolonial urban North. As Ekwensi (1968: 12-13) puts it,

Between Ibo and Hausa at that particular time the gulf was wide. Normally the Ibo man worked like a steam engine, multiplied like the guinea pig and effervesced with honesty. The Hausa man was tolerant, philosophical, accommodating, believing that whatever would be would be. Both had lived peacefully together for a hundred years. Then came politics-the vulture's foot that spoiled the stew.

Actually, Ekwensi is a little inconsistent about the young man Dan Kaybi's background-it seems he is actually of mixed Nupe-Fulani parentage, but as a sort of generalized modern Northerner he seems for most purposes to count as Hausa. Filia, for her part, is likened early on to a wind (that is, Iska in Hausa). Her life will "blow across everything."

As her father dies, having returned back to his village of origin, Filia goes there on her first visit to the ethnic homeland. While there, she learns that her northern fiancé has died as a result of intervening in a Hausa-Igbo gang brawl in his favorite bar in Kaduna. She is under 
some pressure to accept one rather mature Igbo suitor in the village, but rejects him, returns briefly to Kaduna, and then proceeds to Lagos to stay at first with a senior sister and brother-in-law-she hopes for a career as a model.

From there on, this becomes very much another Lagos story: one of partying, job-seeking, networking, driving about in fast cars, finding a roof over one's head, smoking "wee-wee" (cannabis). Betrayed wives show up to bawl out their civil-service husbands (experts at passing the buck) at their offices. Filia, however, succeeds in establishing herself as a model, so her face appears in ads for "soft drinks, sewing machines, toilet soaps, special fabrics." Meanwhile, other men also pass through her life's experience. One is a rent-a-thug available to any political grouping willing to pay him for beating up its adversaries. Another is Piska Dabra, street apostle, with a pointed cap resembling a bishop's, leader of the Prayer People, a mixed collection of people deeply in need of something or other. In the end, Piska Dabra wades out into the lagoon and drowns. Filia gets more seriously involved with Dapo Ladele, who reminds her of Dan Kaybi, her first love. Dapo Ladele is a successful political correspondent at the West African Sensation. Actually, he is already married to a British girl, but she has returned to the United Kingdom and is not expected to come back-she could not stand Lagos. Then, however, politics, and Filia's slight engagement with it, again turn complicated. The suitor she once rejected back in the Igbo village is now in Lagos, a parliamentarian engaged in a breakaway from the major party he has earlier represented. His partners in the new enterprise are a Northerner, Dan Kaybi's father, and a Westerner, married to Dan Kaybi's sister-who would have been Filia's sister-inlaw if things had gone well, and who was a good friend from Kaduna school days. (So the Lagos political world seems very small.) But Filia's old Igbo suitor is under a cloud after having sold communal land at home and thereafter privatized the earnings so that he could send his children to Oxford and Cambridge. Dapo Ladele agrees to edit a new newspaper, the Reformer, on behalf of the new political party, which is already splitting up and on its road to certain failure. And against his better judgment, but to make a handsome personal profit, he writes and publishes a piece heaping praise on his new patron, that corrupt old suitor of Filia's, who is again making advances toward her (to be his Lagos woman, aside from the wife he has back in the village). Filia is deeply disappointed in Dapo, and begins to think about the possibility of a future pursuing her modeling career abroad-England, France, America ... 
But that is not to be. In the end, Filia is indeed, as it were, "gone with the wind." And Dapo Ladele receives a final message from his wife in London, informing him that she will never again come to Lagos.

Once more a portrayal of the lives, in large part on the night shift, of more-or-less successful Lagosians and their more dubious hangers-on. This may well be what, at least at the time, appealed most to readerships both in Nigeria and abroad. That "vulture's foot" of politics is also forever present. In this somewhat later book, there are yet stronger hints of those Afropolitan linkages than before, with Filia's career dreams overseas and that expatriate ex-wife-to-be. And at the same time, there is the street preacher addressing the lumpenproletariat, already encountered among the Afro-Brazilians in Olinto's The Water House, and showing up in later Lagos stories, such as Nnedi Okorafor's Lagoon-see chapter 9.

I can imagine Cyprian Ekwensi rising from that desk with the portrait of the Queen behind him, and going home to write about Jagua Nana. We come back to him in chapter 15. Fast forward now to Chibundu Onuzo's Welcome to Lagos (2017), some sixty years after People of the City. In the years between, literary Lagos has been rather densely populated: by Chinua Achebe, Ben Okri, Chris Abani, Teju Cole, Chimamanda Ngozi Adichie, and others. Welcome to Lagos is Onuzo's second novel-the first, The Spider King's Daughter (2012), was published when she was twenty-one, an intriguing tale of two young Lagosians, girl and boy, engaging with each other. Onuzo was always very mature for her age. The daughter of two Lagos doctors, she left for an English boarding school at age fourteen, and the author presentation in this second book says she was then also working for her doctorate at King's College London. One could note interesting historical connections to Amos Tutuola: Faber and Faber, who first took on Tutuola, now publishes Onuzo, and her first book was shortlisted for the Dylan Thomas Prize.

Lagos has changed, but even if political power is now in Abuja, it is still the Big City. ${ }^{4}$ (One could reflect that the contrast between the two has symbolic parallels elsewhere-between Washington, D.C., and New York, Canberra and Sydney, Brasilia and Rio de Janeiro, even Jerusalem and Tel Aviv.) It keeps growing, too, and newcomers can have a difficult time getting a roof over their heads. To begin with, the odd cluster of people at the center of Onuzo's story, escaping from native as well as governmental violence in the country's southeast, stay under a bridge through their nights, before finding an empty basement in what they take to be an abandoned house. 
Only it is not quite so abandoned. It belongs to a prominent politician, a titled chief who, finding himself out of luck in Abuja, disappears from there with a large sum of government money. He makes his way to his old house in Lagos and finds the handful of people in its basement. They seize him; one of them reports it all to the editor-publisher of an ambitious but mostly unsuccessful reformist newspaper, and that journalist makes his way to the basement to interview the politician. He gets a story, including major counterallegations against people in power in Abuja; when he publishes it, his newspaper office is burned down, evidently on order from higher up, and he has to escape to London, where he had once gone for his university education, and where his family still happens to have an apartment. And where he also has an old girl friend, now divorced, with two daughters, and working for the BBC.

Meanwhile, that group in the basement, under the soft leadership of a former army officer who had fled when he just could not take the cruelty of his superior officer against civilians any longer, takes the money that their politician prisoner has appropriated and starts distributing it to local schools, to improve their facilities and educational standards. The politician-chief begins to cooperate in this venture, until it is time for him to flee-but it is too late. He is imprisoned, yet treated increasingly well, then released ... Let us leave the story there.

It is now an era, however, of a lot of money in some circles, and very little in others, of more or less instantaneous moves between relative opulence and homeless poverty, of quick journeys between Lagos and London, and of lots and lots of international phone calls. Even if one sees some similarities, this is no longer the Lagos of Jagua Nana.

\section{Notes}

1. Lindfors (2010: 111-177) offers a more detailed account of Ekwensi's early life and writings. He is clearly more impressed by the quantity rather than the literary quality of the latter.

2. See, for example, Chukwuemeka Ike's ([1970]1971: 32) description of a faculty wife at the University of Songhai:

She was under 5 foot, with a waste [sic] that her houseboys likened to the trunk of a baobab, and which earned her the nickname of gwongwolo. One could hardly say she had a waist; for the space between her hips and her chest appeared to have been very carefully filled in. But for her breasts, her circumference would have been uniform from armpit to hip. These were proportionately large .... She could walk faster than 
most other women, even though the tremor caused by her footsteps shook nearby houses.

3. There happens to be another brief portrayal of postcolonial Kaduna in a fairly satirical short story by the Sri Lankan writer Ashok Ferrey (2009: 10-27). Kaduna, for a period, had some number of South Asian residents, leading rather modest expatriate lives.

4. I note Adichie's (2017) comment about a new generation of designers: "Most were in Lagos, the most stylish city in the world, where fashion is the one true democracy: from the western-label-loving elite class, to the working poor in their beautifully put-together outfits bought second-hand."

\section{References}

Adichie, Chimamanda Ngozi. 2017. “My Fashion Nationalism.” Financial Times, 21/22 October.

Ekwensi, Cyprian. 1954. People of the City. London: Dakers.

- 1961. Jagua Nana. London: Hutchinson.

- 1962a. An African Night's Entertainment. Lagos: African Universities Press.

- 1962b. Burning Grass. London: Heinemann. 1968. Iska. London: Panther.

Ferry, Ashok. 2009. Colpetty People. Gurgaon: Penguin Random House India. Ike, Chukwuemeka. (1970) 1971. The Naked Gods. London: Fontana/Collins. Lindfors, Bernth. 2010. Early West African Writers. Trenton, NJ: Africa World Press.

Onuzo, Chibundu. 2012. The Spider King's Daughter. London: Faber and Faber. . 2017. Welcome to Lagos. London: Faber and Faber. 


\section{Points of Cultural Geography Ibadan ... Enugu, Onitsha, Nsukka}

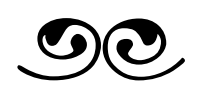

Despite the rise of a new Abuja out there on the savanna, Lagos remains in many ways the center-in commerce, as a media capital, as Nigeria's megalopolis, as the only place with a claim to being a world city. Yet Lagos is not everything. A number of other Nigerian cities have played their significant parts, in different ways and at different times, in the development of Nigerian writing. What follows will highlight only some of their features, and some people and institutions involved.

\section{lbadan}

In some ways, Ibadan, not so far away, may have been just about equally important as Lagos-not as a topic, but, at least in one period, as a setting for intellectual and aesthetic work. To begin with, of course, it was a classic, very large Yoruba agricultural town-although with a somewhat late start as a nineteenth-century war camp. ${ }^{1}$ Then, as the politico-administrative order of modern Nigeria took shape, it became a regional capital: when the country to begin with was divided merely into three regions (Northern, Western, and Eastern), Ibadan became the capital of the West, which covered the Southwest and was Yorubadominated. Later, as the states of the Federation kept subdividing (now there are thirty-six), Ibadan would remain the capital of one of them.

That provided some of the infrastructural basis for early intellectual production. But at least as important was the fact that in the late colonial period, the first Nigerian university (starting as, and remaining for some time, a "university college" subordinate to the University of 
London) was established here. To begin with, it was for the most part rather ordinarily academic, with a largely expatriate teaching staff. Gradually, however, other things began to happen, more or less offcampus. The paragraphs on Ibadan that follow dwell mostly on this period, around the arrival of Nigerian independence, when it was strikingly central to the growth of Nigerian literature and arts.

The spider in the web for much of this activity was the remarkable, originally German-Jewish intellectual entrepreneur Ulli Beier, for an extended period in the company of his wife Susanne Wenger. Here is a remarkable life story. Beier was born in 1922 in a small German city that after World War II became a Polish city. As Hitler came to power in Germany, the Beier family moved to join the Jewish community in Palestine (the state of Israel, of course, did not yet exist). After the war ended, by which time Ulli was an adult, he went to London as a student, and earned a higher degree in phonetics. But academic jobs were scarce in postwar Britain, so he took off for a position at that new outpost in Nigeria. And he brought his wife, Austrian artist Susanne Wenger, whom he had met on an excursion to Paris.

Soon enough he shifted from teaching phonetics to a job with the Extra-Mural Studies Department, which could serve as a base for varied outreach initiatives. It probably mattered that Beier and Wenger were of German and Austrian background, and therefore not entirely part of a still mostly British expatriate community. So they more or less "went native," forming strong links to local life and to the emergent late-colonial intellectual and artistic networks.

The several sophisticated periodicals coming out of Ibadan around this time bear evidence of the outcome. The journal Ibadan may have been basically aninstance of academicin-house publishing: commentary and reviews were by a mixture of expatriate and Nigerian faculty, with advertising by foreign publishers as well as local businesses. Beier did not figure so much in this. But Odù: Journal of Yoruba and Related Studies, published by the Western Region Literature Committee, had Beier as one of its editors. And most importantly, there was Black Orpheus, steadily edited by Beier, with a varied series of coeditors. It described itself as "a Journal of African and Afro-American Literature," and in the editorial committee were people such as Aimé Cesaire, Léopold Sédar Senghor, and Ezekiel Mphahlele, as well as Chinua Achebe and Wole Soyinka. Black Orpheus reached out into the world of Black literature-for example, Ulli Beier was in touch with the mostly Francophone networks of Presence Africaine and Négritude-at the same time as it published the coming generation of Nigerian writers, 
as well as graphic illustrations by Nigerian artists. Achebe and Soyinka had both been University College of Ibadan students.

To begin with, the journal was sponsored by the Western Nigerian Ministry of Education, but by the 1960s it identified itself as a publication of the Mbari Club, Ibadan. Here was another entity within Beier's field of cultural enterprise. The Mbari Club was located at what had earlier been a Lebanese restaurant. The name came from an Igbo ceremony, with its associated local architecture, and was suggested by Chinua Achebe; being in Ibadan, it suggested a postethnic stance. It offered a library, an art gallery, and performances. In the early postindependence period, then, it was also central to making Ibadan what it was as an intellectual and aesthetic center. ${ }^{2}$

As Nigeria entered into a period of military coups, civil unrest, and war, Ulli Beier saw that his work there was coming to an end. Perhaps it was also true, as one commentator has suggested, that "his insistence on his own, possibly esoteric, standards brought him into conflict with some of his African co-editors and contributors" (Rea 1976: 102). In any case, he left, with his new wife (a British artist), for Papua New Guinea, where the couple began building up another cluster of cultural activities not so unlike what had been at Ibadan. The University of Ibadan, as it came to be in the troubled period of the late 1960s, was described in detail (ritually pseudonymized as the University of Ilosho) by the sociologist Pierre van den Berghe (1973), who spent a period researching the institution. Van den Berghe had an interesting personal background: while by the time of writing he was a professor at an American university, he was of Belgian family background, born in Lubumbashi at the time when it was Elisabethville, in the Belgian Congo, and had extensive research experience in various parts of Africa before he came to Ibadan. So here was perhaps another variation of Afropolitanism. ${ }^{3}$

Susanne Wenger, for her part, remained in Nigeria when Ulli Beier left, continuing artistic and educational work, and becoming a Yoruba cult priestess in Osogbo, ninety kilometers or so northeast of Ibadan. Renovating a decrepit old sacred grove at Osun River, she recruited more priests and priestesses, added numerous new sculptures, and attracted pilgrims and tourists. Osogbo also became the capital of a new state. In 2005, a few years before her death at ninety-three, Wenger's efforts were well rewarded, as UNESCO made the shrine Nigeria's first World Heritage site. ${ }^{4}$

As far as Ulli Beier's Africanist entrepreneurship was concerned, however, it was not over yet. Returning once more to Germany, he established an institution named the Iwalewa-Haus in the north 
Bavarian city of Bayreuth, otherwise mostly known as the birthplace of the composer Richard Wagner, and for the annual Wagnerian Festspiele. The Iwalewa-Haus (Iwalewa is Yoruba, meaning "Character is beauty") organized high-profile cultural events and exhibitions, continuing after Beier retired. Could one see it in a way as the Mbari Club reborn? It certainly played a part as the new university in Bayreuth emerged as a center for African studies in German academic life. As local rumor has it, it probably also helped that the prime minister of Bavaria, Franz Josef Strauss, after he had been on a safari to East Africa, was strongly supportive.

If we return from Ibadan to Lagos by road, we should not miss a stopover in Abeokuta, now capital of Ogun State. Amos Tutuola was born there. We may remember, too, from chapter 1 that this is where the Swedish author-traveler Artur Lundkvist met with the political leader, woman activist, and educator Funmilayo Ransome-Kuti, later also known as the Afro-beat musician Fela Kuti's mother. Their family network in Abeokuta would include Wole Soyinka, who keeps a home there, although he has had to spend periods in exile. We get a view of Fela Kuti's Abeokuta childhood in Carlos Moore's Fela, Fela: This Bitch of a Life (1982), and of Soyinka's in one of his autobiographical books, Aké (also 1982). And, in chapter 3, we learned that Dilim Okafor-Omali, early Igbo author, had gone to grammar school in Abeokuta.

We may remember as well, from chapter 2, that in Antonio Olinto's novel The Water House, the elderly Brazilian ex-slave Catarina, who returned to West Africa with her family, had grown up in this town. More recently, former president Olusegun Obasanjo has established a presidential library in Abeokuta, also as a research institution in its own right—although he is not always around, as he has maintained varied international activities. (For one thing, he served a period as president of Transparency International, the anti-corruption organization.)

\section{Enugu}

Enugu is in a way the southeastern Nigerian counterpart of Ibadan; since the late colonial period, it has always been the capital of something or other. But its origins are different. While Ibadan was a traditional precolonial city, Enugu has later origins. As the British established their domination further inland, theirs became an extractive colonialism. Tin was found on the Jos plateau, coal at Enugu. Thus railways were built from both of them to the new harbor at Port Harcourt to move the minerals overseas. Enugu for its part developed as a modern colonial 
mining town, with workers coming in from a wider area, and with its expatriate cluster as well. When in the late colonial period Nigeria was divided into three regions, Enugu was a sufficiently large and welllocated urban center to become the capital of the Eastern Region. Then, briefly, it was the capital of Biafra, although Nigerian forces took it back soon, so that the new country had to move elsewhere for a provisional capital. Now it is simply the capital of Enugu State.

Conditions in the mining industry could be volatile. In 1949, the police shot and killed twenty-one striking mine workers, injuring many more. At the time, this was fuel for nationalist politics, especially for the National Council of Nigeria and the Cameroons (NCNC), the movement started by Nnamdi Azikiwe, the leading Igbo politician. Enugu, of course, was in the Igbo heartland. By the mid-1950s, Azikiwe was in power (such as the colonial administration by then allowed) in Enugu, as premier of the Eastern Region. This was consequently the scene of his regional governing activities and the base for his continued nation-wide campaigning. At Nigeria's independence, he moved on to become the first governor-general, and later the first president of the new republic, by which time he was of course based in Lagos. With the first military coup in 1966, he was among those who lost his job; but although he went back to the East for a brief period, he was of two minds about the Biafra secession and returned to Lagos. His later attempts at a political comeback did not work out.

After the Biafra war, Enugu could return to developing in peace, as an example of self-generating metropolization. In 2006, the census had the Enugu population as 722 thousand. What could it be now800 thousand? A million? Newer state capitals in other states later created in southeastern Nigeria could not easily compete with Enugu. Although without a major university of its own, it has a number of institutions of higher education. Several regional newspapers are published out of Enugu. In different postwar periods there have also been some ambitious publishing houses. Flora Nwapa, the first Nigerian woman writer to be internationally published, with her Efuru (1966), was a minister in the state government for several years in the 1970s, and established her own publishing enterprise in Enugu. Another enterprise was Fourth Dimension Publishing, started by the chief Victor Nwankwo and two of his brothers. ${ }^{5}$ It published Cyprian Ekwensi's Divided We Stand and two children's books by Chinua Achebe. But in 2002, Nwankwo was murdered outside his home in Enugu, apparently a political assassination. In the publishing business was also Dillibe Onyeama, another writer, with Delta Publishing. And 
yet another enterprise was NOK Publishers International (presumably named after the home of the famous antique Nok terracotta sculptures, found in a Northern Nigerian village), also publishing more academic style works. ${ }^{6}$

As far as literary portrayals of Enugu are concerned, there is at least one, Coal City, by Ogali A. Ogali (1977). But the sense of place in this book is not so strong, though there is plenty of action-see the next chapter.

\section{Onitsha}

Onitsha-let me start some six hundred kilometers away from there, in my town, Kafanchan. The Igbo, who had been a very strong element in the population of this town, had all left it by the outbreak of the Biafra War (see chapter 14). As they came back in the early 1970s, some were old-timers, hoping to reclaim their abandoned properties; others were younger people who had actually never been there before. While some advantageous niches in the urban economy could not be reclaimed, quite soon they were back running a great many of the stalls in the Kafanchan market place.

One of my good friends and key informants was Shadrack, a young Igbo who ran a stall mostly selling soap and cosmetics to a female clientele. He had been set up in business by an older brother, who had his own stall nearby selling another slightly more expensive line of goods. Moreover, there was already a young teenage relative helping Shadrack with odds and ends. The Igbo, then, were repopulating the Kafanchan market by way of chain migration.

How come they were doing so well again? The answer may be multifaceted: the Igbo tended to be hard-working and privately rather spendthrift. But when I talked to Shadrack about such matters, he would also emphasize the geography of longer-distance wholesale trade. What Hausa traders sold at the Kafanchan market was in large part things like tomatoes, peppers, and onions, grown mostly in Hausaland, and this was a basis for more or less an ethnic monopoly. One might have thought that with regard to electrical items, textiles, or cosmetics, such a factor would matter less, but this is where Onitsha came into the picture. The huge Onitsha market had a uniquely large supply of imported goods, and it had recovered quickly after the war. Igbo traders, wherever they had established themselves in the reborn diaspora, would try to get to Onitsha to pick up supplies if they could 
afford the journey. Traders of other ethnic groups were more wary, uncertain whether the Igbo wholesalers would be as well-disposed toward them. As Christmas approached and Shadrack was planning a purchasing trip to Onitsha, I gave him a small loan so he could expand his line of goods to include some ladies' shoes.

Cyprian Ekwensi's Jagua Nana, in the end, set herself up in Onitsha, on the River Niger, to become a merchant princess. The Onitsha market, however, has also been the site for a small-scale writing and publishing industry that has drawn international attention. This industry seems to have come into being in the late 1940s, with numerous small printing presses turning out the work of a great many local writers. These early Onitsha writers, making a living from something else and writing in their spare time, were basically pamphleteers: their published work would mostly be thin and ugly, unevenly printed. A fifty-page volume would be substantial, and many would be considerably less. But they were cheap, and the number of copies sold could be quite large. By way of those Igbo traders coming to Onitsha from elsewhere in the country, they could now and then find their way to other Nigerian markets as well. This cultural petty entrepreneurship provided sustenance of many kinds for the imagination of townspeople, as well as practical and moral advice. There were romances, political tracts (about national and other African affairs), biographies, local histories, and advice on proper moral conduct and roads to success in life. The occasional Onitsha author might graduate to a more sophisticated national outreach through other publishing channels, although that did not happen so frequently.

Emmanuel Obiechina, lecturer at the University of Nigeria, Nsukka, at the time, devoted a monograph to the Onitsha writing and publishing industry in 1973 (with a foreword by Chinua Achebe, and including reprints of several pamphlets as an appendix). ${ }^{7}$ This may have been around the time when it reached its greatest glory. Some commentators would compare it to London's nineteenth-century Grub Street. A little later, there is a wry comment by another Nigerian scholar: "Possibly none of the Onitsha writers ever thought that their pamphlets would ensure their lasting fame as writers. Probably none ever thought that the locally produced pamphlets intended only to amuse would draw the attention of University dons, literary critics and intellectuals of high order all over the world" (Emenyonu 1978: 84). ${ }^{8}$

But then there is also one very different Onitsha writer. The novel by J. M. G. LeClézio, winner of the Nobel Prize in Literature in 2008, is indeed named Onitsha (1992, in English translation 1997). LeClézio, 
who identifies himself as Franco-Mauritian, has his own local past. His father was for a period a doctor in Nigeria and brought his family to live there for a couple of years in the late 1940s, when his son, already showing a talent for writing, was between eight and ten years old.

So the Onitsha story is one about an expatriate family in this city in the late colonial period. ${ }^{9}$ The British husband-father, working for a major trading company, somewhat belatedly gets around to sending for his wife and young son to come out from Europe and join him. But they fit poorly into the local British colonial establishment of administrators and merchants. The wife does not even have quite the right pale hue of skin, as she is southern European. They get together with other Europeans, who are likewise marginal, but in different ways they also make contact with local African society. The husband becomes preoccupied with the early, semi-mythical history of the continent, reading widely. The wife approaches the natives of Onitsha more directly, as does their son. This draws them toward less accessible sides of Igbo ritual life.

As rumors about such conduct reach people at the British club, members are scandalized. These rule-breakers have to go. Arrangements are made to send them back to Europe-although not before the husband has been seriously ill: black-water fever. As the book ends, the son is at an English boarding school, hearing from afar about people dying in Biafra, and remembering their faces.

LeClezio's novel appears to be a blending of fictionalized childhood memory with elements from the intellectual and literary climate of late twentieth-century Europe. It stands as an effective, dramatic critique of a colonial order.

Since the precolonial era, it should also be said, Onitsha Igbo society was a little different from the Igboland further to the east, away from the big river. Onitsha was in touch with the more hierarchical civilization of Benin, seeming to deviate somewhat in a culturally hybrid manner from the egalitarianism of most of Igbo rural society, with certain inclinations toward aristocracy, viewing itself as more sophisticated, contrasting with rustic inland people. It also mattered that, in colonial times, Onitsha had a head start with regard to educational institutions. ${ }^{10}$ Nnamdi Azikiwe was of a leading Onitsha kin group, although his father was among those Igbo who went north with British colonization. So Nnamdi (also named Benjamin) was born in Zungeru, another new railway town. But he reconnected with his Onitsha roots regularly, and these had a part in his public identity. 


\section{Nsukka}

Nsukka is forty-seven kilometers north of Enugu.

A new university was one of Azikiwe's symbolically most central projects as premier of the Eastern Region: indeed the University of Nigeria at Nsukka became the country's first independent university, as Ibadan still formally had the dependent status of a university college. The latter, located in the Western Region, may have been seen as Yoruba-dominated, and there was an Igbo-Yoruba rivalry that could also reach into academia, at least as perceived in its politicized surroundings. (Actually there was a significant Igbo scholarly presence at Ibadan as well. ${ }^{11}$ ) But then the University of Nigeria also became a locus of an alternative academic tradition. Azikiwe had returned to Nigeria from the United States, with his own experience of historically Black institutions, such as Lincoln University in Pennsylvania, and, as a powerful politician in emergent Africa, he stood out as an attractive partner for American land-grant universities with their own internationalist ambitions.

In the early years, nonetheless, there was still evidently widespread doubt that legitimate academic knowledge could come from anywhere but the United Kingdom, with its modes of imperial outreach. In an interview as late as 2016, the veteran author and educational administrator Chukwuemeka Ike would reminisce that not everybody took kindly to the introduction of American ideas of higher educationand it was predicted in some circles that the new institution would turn out unemployables with degrees. ${ }^{12}$

Our image of Nsukka may have come to depend a great deal on what Chimamanda Ngozi Adichie has had to say about it, here and there in her novels and short stories (fiction, but in these moments shifting into nonfiction?). It was already there as a setting in her first book, Purple Hibiscus (2004). Then Nsukka was "a little patch of dust in the middle of the bush, the cheapest land they could get to build the university on"- this is what Adichie (2007: 68) has one of her key figures, a young Igbo woman, say in Half of a Yellow Sun. But the utterance was supposedly made some time in the early 1960s, and Adichie was born in 1977. She did grow up in Nsukka, however, and is now certainly an important part of its claim to fame.

At about the same time, in the same novel, a radical Nigerian faculty member at the university is quoted as saying that "Nsukka was full of people from USAID and the Peace Corps and Michigan State University," so he wanted a forum for the few Nigerian lecturers (Adichie 2007: 76). But again, that would be more than a half century ago now. 
During the years of secession and war, the University of Nigeria turned into the University of Biafra. Non-Igbo faculty soon left; Ken Saro-Wiwa, a lecturer whose home was in a non-Igbo Niger Delta area of the Eastern Region, was among those departing. We will come back to him. Yet, as Nsukka was far to the north in the new country, it was quite soon overrun by Nigerian forces.

After the war, it was back to being the University of Nigeria. Here was an academic company town-the rest of Nsukka did not amount to much. Chinua Achebe came for a professorship in the 1970s, in part to edit the cultural journal Okike, but has not had much to say about Nsukka, and later spent more of his time in the United Statesespecially after the Lagos traffic accident that made him an invalid. To his American engagements we come back in chapter 15 .

Chimamanda Ngozi Adichie has again had a few more comments. In one story in The Thing around Your Neck, she refers to the sort of intra-academic distancing found in university life in many parts of the world- "many of us in the proper sciences thought that the social sciences people were empty vessels who had too much time on their hands and wrote reams of unreadable books" (Adichie 2009: 60). In another she relates how once benign undergraduate fraternities turned into "cults" - the Black Axe, the Buccaneers, the Pirates-at war with each other, going through secret and strange initiations, mastering the swagger of American rap videos (Adichie 2009: 7). This sounds not so different from what we will find another observer lately reporting from Ibadan, in chapter 18 .

Nsukka, along with its university, shows up in Adichie's Americanah too. Before the heroine Ifemelu takes off for the United States, she tries the University of Nigeria. She and her boyfriend, son of a professor, go off-campus for a meal, "sit on wooden benches in the dimness of the restaurant, eating, on enamel plates, the tenderest of meats and the tastiest of stews" (Adichie 2013: 90). But under the military government, faculty members are not getting their salaries. ${ }^{13}$

While still in Igboland, we should not altogether ignore Umuahia. It is now the capital of Abia State; after Enugu was lost to Nigerian troops, it was for some time the provisional capital of Biafra. Before that already, it was the site of the Government College Umuahia, a secondary school that counted among its midcentury students Chinua Achebe, Ken Saro-Wiwa, Chukwuemeka Ike, and the poet Christopher Okigbo, killed early in the Biafra war. One of the young, inspiring teachers at the college was Saburi Biobaku-notably a Yoruba sojourning in deepest Igboland. Biobaku would go on to become one of Nigeria's leading historians, with an academic career that included 
the vice-chancellorship at the University of Lagos. Achebe, for his part, notes that he learned to play cricket at Umuahia. ${ }^{14}$

In this chapter, we have made some stops in southwestern and southeastern Nigeria. In chapter 13, briefly, we will look in at Zaria, and its Ahmadu Bello University, as part of an excursion to the north.

\section{Notes}

1. In an early book I wrote about the anthropology of cities, I could point to the Yoruba agritown as an exemplar of the primordial kind of human urbanism (Hannerz 1980: 83), drawing on the comparative work of the historical geographer Paul Wheatley (1970).

2. Without mentioning the Mbari Club in this context, Achebe (2009: 108111) offers a view of the original Igbo mbari, "communal enterprise in creativity," in The Education of a British-Protected Child. In There Was a Country, Achebe (2012: 115) mentions Beier, but only quite brieflyperhaps not being inclined, in this context at least, to foreground an expatriate? Wole Soyinka (2006: 68-69, 73), on the other hand, has more to say about Beier and Wenger, and describes the Mbari club as "that cultural roosting place that doubled as a venue for artistic manifestations and political intrigue." Ezekiel Mphahlele, South African writer, spending some time in exile in Ibadan, also comments on the Mbari Club and Black Orpheus with some enthusiasm (see Manganyi 1983: 181, 211-212). Particularly on the influence of Beier, Black Orpheus, and the Mbari Club on the development of Nigerian art, see Okeke-Agulu 2015: 131-181. Beier himself has a richly illustrated chapter on Mbari houses in Igboland in his book African Mud Sculpture (1963).

More recently Juliana Spahr (2018: 93ff.), American literary scholar, has pointed to links between Beier and the Congress for Cultural Freedom, later revealed to have been a front organization for the CIA during the Cold War. After more than a half-century, the concrete information here seems scanty, with little connection to past local Ibadan circumstances; it is not clear that the Congress for Cultural Freedom, to Beier, might have been anything other than a welcome source of cash.

3. Pierre van den Berghe was my colleague for a year at the Center for Advanced Study in the Behavioral Sciences in Palo Alto, California, 1984-85.

4. For a rich historical and ethnographic study of the Osogbo shrine, see Probst 2011. Early in his scholarly career, Probst was at the IwalewaHaus in Bayreuth. See also Wole Soyinka 2006: 68-69 and Matory 2018: 318-321 for comments on Susanne Wenger's background and long-term influence.

5. As I understand it, the rather early Afropolitan writer Nkem Nwankwo was not directly related to them. He came from the Onitsha area, took an Ibadan degree, moved to the United States, and went into academic life, 
remaining there until his death. He reached a certain fame especially with his novel Danda (1964).

6. Such as Remi Anifowose's Violence and Politics in Nigeria: The Tiv and Yoruba Experience (1982). Fourth Dimension published related kinds of nonfiction as well-for example, the Biafran general Alexander Madiebo's The Nigerian Revolution and the Biafran War (1980). Madiebo was also a high-level Nigerian army officer when younger Igbo officers made their January 1966 coup, and traces the events leading up to the Biafra secession, as well as all that followed.

7. Obiechina later moved up to a professorship at Nsukka, and into university governance; he died in Silver Spring, Maryland, the Washington suburb, in 2010.

8. Emenyonu was the head of Department of English Language and Literature at Alvan Ikoku College of Education, Owerri. For a further brief comment on the Onitsha literature, see Griswold (2000: 66-68), who suggests that returning soldiers had a part in its post-World War II development.

9. LeClézio’s description of Onitsha colonial life may be largely fictitious; in a later book (LeClézio 2013), a biographical portrait of his father places the latter's service as a doctor in Igboland in more remote Ogoja.

10. See on this Isichei 1976: 190-191. The American anthropologist Richard Henderson has analyzed the complexities of Onitsha social structure in considerable detail, while committed to applying metropolitan social theory as it was at the time. One may find it puzzling that in a monograph about Igbo society published in 1972, there is no mention whatsoever of the war that ended a couple of years earlier, and one would have liked to learn more about Henderson's field research, meticulous as it obviously was.

11. This is shown quite clearly in van den Berghe's (1973) study. For one thing, its first Nigerian principal, the historian K. O. Dike, was an Igbo.

12. The interview with Chukwuemeka Ike appeared in the Vanguard, 5 November 2016 (available on its web site). Ike also has a novel, The Naked Gods (1970), sited at the fictitious University of Songhai, which seems in part inspired by the institution at Nsukka. There is an American vice-chancellor, and a number of American visiting professors provided through the Save the Underdeveloped Nations Scheme (SUNS). These are in continuous competition, however, with British staff members, such as the registrar, James Toogood, and one of the issues of conflict is who will be the first indigenous vice-chancellor. The two candidates seem to compete over who is most underqualified. All this, of course, is an often hilarious but rather gross parody.

13. We get a glimpse of Nsukka in more recent times in a portrait of the Ghanaian-Nigerian sculptor El Anatsui by Julian Lucas (2021) in the New Yorker. Anatsui has been in Nsukka since 1975.

14. It also turns out that evidently a little later, when he was a student in London, Biobaku would have a part in "authenticating" the manuscript of Tutuola's The Palm-Wine Drinkard on the advice of Professor Daryll Forde to the publisher (cf. Lindfors 2010: 22, and chapter 1, note 1). Achebe (2012: 21-26) discusses his Umuahia period in There Was a Country, his "personal history of Biafra." 


\section{References}

Achebe, Chinua. 2009. The Education of a British-Protected Child. London: Penguin.

- 2012. There Was a Country. New York: Penguin.

Adichie, Chimamanda Ngozi. 2004. Purple Hibiscus. London: Fourth Estate.

- 2007. Half of a Yellow Sun. London: Harper.

- 2009. The Thing around Your Neck. London: Fourth Estate.

- 2013. Americanah. London: Fourth Estate.

Anifowose, Remi. 1982. Violence and Politics in Nigeria: The Tiv and Yoruba Experience. Enugu: NOK Publishers.

Beier, Ulli. 1963. African Mud Sculpture. London: Cambridge University Press. van den Berghe, Pierre. 1973. Power and Privilege at an African University. London: Routledge \& Kegan Paul.

Emenyonu, Ernest. 1978. The Rise of the Igbo Novel. Ibadan: Oxford University Press.

Griswold, Wendy. 2000. Bearing Witness: Readers, Writers, and the Novel in Nigeria. Princeton, NJ: Princeton University Press.

Hannerz, Ulf. 1980. Exploring the City. New York: Columbia University Press.

Henderson, Richard N. 1972. The King in Every Man. New Haven, CT: Yale University Press.

Ike, Chukwuemeka. 1970. The Naked Gods. London: Harvill.

Isichei, Elizabeth. 1976. A History of the Igbo People. London: Macmillan.

LeClézio, J. M. G. 1997. Onitsha. Lincoln: University of Nebraska Press. 2013. The African. Boston, MA: Godine.

Lindfors, Bernth. 2010. Early West African Writers. Trenton, NJ: Africa World Press.

Lucas, Julian. 2021. "Structure and Flow: How El Anatsui Broke the Seal on Contemporary Art.” New Yorker, 18 January.

Madiebo, Alexander A. 1980. The Nigerian Revolution and the Biafran War. Enugu: Fourth Dimension Publishers.

Manganyi, N. Chaboni. 1983, Exiles and Homecomings: A Biography of Es'kia Mphahlele. Johannesburg: Ravan Press.

Matory, J. Lorand. 2018. The Fetish Revisited: Marx, Freud, and the Gods Black People Make. Durham, NC: Duke University Press.

Moore, Carlos. 1982. Fela, Fela: This Bitch of a Life. London: Allison and Busby.

Nwankwo, Nkem. 1964. Danda. London: Andre Deutsch.

Nwapa, Flora. 1966. Efuru. London: Heinemann.

Obiechina, Emmanuel. 1973. An African Popular Literature. Cambridge: Cambridge University Press.

Ogali, Ogali A. 1977. Coal City. Enugu: Fourth Dimension Publishers.

Okeke-Agulu, Chika. 2015. Postcolonial Modernism: Art and Decolonization in Twentieth-Century Nigeria. Durham, NC: Duke University Press.

Probst, Peter. 2011. Osogbo and the Art of Heritage: Monuments, Deities, and Money. Bloomington: Indiana University Press.

Rea, Julian. 1976. “Aspects of African Publishing 1945-74.” In Christopher Fyfe (ed.), African Studies Since 1945. London: Longman. 
Soyinka, Wole. 1982. Aké. New York: Random House.

- 2006. You Must Set Forth at Dawn. New York: Random House.

Spahr, Juliana. 2018. Du Bois's Telegram: Literary Resistance and State Containment. Cambridge, MA: Harvard University Press.

Wheatley, Paul. 1970. The Significance of Traditional Yoruba Urbanism. Comparative Studies in Society and History 12(4): 393-423. 


\section{CHAPTER 7 \\ Been-To \\ Dreams, Disappointments, Departures, and Returns}

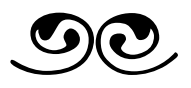

This is about the been-to (or beento, or bintu): the kind of Nigerian (mostly young) who in the late colonial or early postcolonial period would go abroad, preferably to Britain, usually in pursuit of more education, and then return home for a career. There were would-be been-tos as well.

The idea of going to the United Kingdom made girls in Nigeria very flexible in their dealings with boys.

Nne had been dreaming of going to the United Kingdom, and how and when to get to her land of dreams could only be deciphered by her alone.

All attempts to get a scholarship award proved abortive. She had no money, to start with. Most of her class-mates had left for the U.K. To crown it all, a greater number of her girl friends had left the country for the United Kingdom, to join their husbands, and this mass exodus of girls worked faster than poison in her blood.

She must go to England! (Ogali 1977: 13-14)

This is from Ogali A. Ogali's novel Coal City, which is in large part about Nne. If Enugu is her real habitat, her dreamland is overseas, and so Nne becomes known as "Baby UK."

Ogali stands as the author of works in many genres, not least dramapopular works more or less coming out of the Onitsha tradition. Coal City, which becomes rather a burlesque, was published in Enugu by Fourth Dimension Publishers.

Nne, "Baby UK," teaches in an Enugu school. When her attempts to get an overseas scholarship for herself fail, her next strategy is to find a suitable boy with a scholarship so she can go as his wife. She uses her 
organizational asset as secretary of the Choose Me Social Club to invite all the likely, and attractive, male candidates to an event, at which she presents herself in the best possible light. And indeed, there she and Okoro meet each other. Okoro is a cashier at a local bank, and has had a letter from the Balham and Tooting College of Commerce, London, granting him admission to a course. Now only the funding is missing.

At the bank, Okoro manages to lay his hands on a blank check from a wealthy customer and makes it out to himself for a large sum. $\mathrm{He}$ marries Nne, and they get on the plane from Enugu to Ikeja Airport, Lagos, for the connecting flight to London. However, when they are about to board that latter plane, Okoro is arrested. His check theft has been discovered.

Nne returns to Enugu, and soon enough she has also returned to her maiden name. Okoro is not heard of again.

Apart from Nne, there is a second central figure in Coal City: Emenike, from a wealthy business family in Umuahia, doing a rather careless day job at the post office, but more active during the night shift. He has seven main women friends, one for each night of the week, and is also known as "Stormy Weather." Then he makes a very expensive mistake at the post office counter and is fired. As his widowed entrepreneur mother is tired of his escapades, she refuses to keep on paying for them, or even for his unemployed survival.

Meanwhile, Nne gives up on the marriage strategy for getting to the United Kingdom, although not entirely on getting there somehow. She gets into a lot of loose living, and her reputation is no longer so good. One day she gets a cable from a Yoruba senior civil servant/ businessman, based in Lagos, although she has met him once at an Enugu dance. He invites her to Lagos and sends a ticket. So off she goes for a flight to Ikeja Airport once more. In Lagos, her new admirer puts her up in his elegant apartment and says that as soon as his divorce is over, he and Nne will go on an extended international tripto include two months in London. (And during a couple of weeks in Rome, perhaps they could get the Pope to marry them?)

Again, however, there is trouble. While Nne is alone in the apartment, a "Thick Madam" appears at the door. Nne's male friend is her husband, and there is a violent fight between the two women. Nne needs emergency medical treatment, and is then flown back to Enugu. The fight is described by a Lagos newspaper under the headline "FIGHT OVER A MAN, AND THE INTRUDER HAS TO BE PARCELLED HOME BY AIR."

Stormy Weather, homeless, is absorbed into a group of other apparent down-and-outs-but they turn out to be a somewhat sect- 
like group of robbers. He is initiated into it through a ritual including the sharing of a calabash of palm wine, some meat, a kola nut, and a male lizard, plus a lecture on what the leader calls "rogueology" and "escapeology," and then the next night the gang heads for a massive attack on an apartment building. While they are ransacking the homes, however, some witness manages to call the police-and so Stormy Weather and the other bandits are taken into custody. Fortunately, his very effective mother learns about this and comes in from Umuahia to Enugu to fix things with the police, and her son becomes a witness for the prosecution. He returns with her, joins her business, her church, and her political party, and begins a new life.

And Nne? At an Easter Dance, where as usual she outshines the female competition, she is approached by a man who presents himself as a recent returnee from England, with a fresh $\mathrm{PhD}$, just beginning as a lecturer at the University of Nigeria, Nsukka. He argues that with her excellent command of English, she just needs a little polishing off at a British institution before she can start a new career. And so they drive off together in the night, ending up in a modest hotel with mostly a prostitute clientele. While Nne is fast asleep, her escort makes his exit with her gold wristwatch. He gets into his car. He has already removed the TAXI sign from the roof to make it more anonymous.

Then Nne somehow joins an undercover branch of the police force, helps catch a currency forger, and is quickly promoted. On the other hand, she finds herself pregnant, and seeks out a witch doctorabortionist. This is in Aba, two taxi rides away. When she comes back from that, she finds her apartment totally empty, the result of a burglary.

She, too, returns home, to the slow village life with her parents. She, too, begins to devote her time to the local church. Emenike, ex-Stormy Weather, who had already noticed her in Enugu in the past (but had been spurned), hears from a distance of this change, and contacts her. This time it eventually results in a grand wedding in Umuahia, with Emenike's mother's friends in the political elite present. Nne gets to run a new fancy fashion store, while Emenike becomes very wealthy in the timber business. Back in Enugu, as he is visited by those seven once-a-week girlfriends of his past, his wife walks in, to sit on his lap observing all those other women as they get into a free-for-all fight.

Quickly on to a final scene: the matronly Nne is being interviewed by a journalist about her work with the Young Women's Christian Association, when her two young children, a boy and a girl, come in. They both speak very good English, and the ex-Baby UK notes that she and her husband have plans for them. They will go to the United 
Kingdom, "where Chikwendu will do Business Administration when he grows up, and Chinyere will do Medicine."

All this in some 160 pages.

Ogali Ogali's been-to story is thus about the imagined been-to, in two generations, all mostly in and around Enugu (with those brief Lagos excursions). But there are also stories about been-tos who do go abroad and come back. In Obi Egbuna's The Madness of Didi (1980), the middle-aged, learned-but-mysterious Uncle Didi comes back to his home area after a long period in Britain. His presence causes considerable local upheaval-but it turns out that he was somehow released and sent off to his home country following a long period in prisons and madhouses, after he had killed six people. With a Father O'Dennehy (who had saved him when he was orphan child) as his original guide, he was supposed to have trained for the priesthood, but then he joined a political terrorist group instead and committed his crimes.

As Uncle Didi is on his deathbed, he reminisces about his life to a young local man, Obi, who has the hope of becoming a trader selling motor parts. But Uncle Didi challenges him to aim for something better, and also sends off a letter abroad. It turns out to be addressed to a Dr. Schlomo Guddman, Oxford Street, London. Guddman, an extremely wealthy man who has risen from a Polish refugee background to a fortune in publishing and other pursuits, supported Didi in Britain and was behind his release and return to Africa. Now it turns out that he will also support young $\mathrm{Obi}$-who under such conditions has decided that he wants to go abroad to study, somewhat surprisingly, librarianship-for the road to becoming a writer is through reading. Again, the bright future is overseas.

The presentation of the author at the front of The Madness of Didi states that Obi Egbuna completed the book while studying for his PhD at Howard University, Washington, D.C.

Before that, he received a master's degree in English from the University of Iowa. (That would have been before Amos Tutuola came there.) One may wonder a little about the occasional similarity between Uncle Didi's career and Egbuna's own. Obi Egbuna was for a period one of Nigeria's most productive writers. ${ }^{1}$ During the years of the Biafra War and the period leading up to it, he was in Britain engaged in radical politics, participating for one thing in the British Black Power movement. In the 1970s, he was back in Nigeria, in the East, as a writer and public intellectual, but he then returned to the United States. He died in Washington, D.C., in 2014. His son, Obi Egbuna Jr., who was 
following in his father's footsteps as a transnational Black activist, took his ashes to be scattered at the Victoria Falls in Zimbabwe. ${ }^{2}$

Ogali, to repeat, has his roots in the Onitsha pamphleteer tradition, and the been-to is indeed a recurrent figure in it. One might expect returning been-tos to be success stories, coming home with new credentials and cultural capital. To an extent, Uncle Didi could seem to have done that. But among the Onitsha writers, Obiechina (1973: 54-55) concludes, the been-to is ambiguous and frequently dangerous. Men who are not been-tos themselves, in particular, should beware of been-to women. An "unsophisticated and unspoilt village damsel" is regarded as a better bet.

Obi Okonkwo in Chinua Achebe's No Longer at Ease (1960) is a prominent example of how been-tos are often tragic figures. Obi is a smart boy in Umuofia, the small Igbo town where his father is a catechist (and also, of course, at an earlier time the setting of Things Fall Apart). Townspeople get together to help him along financially in furthering his education. He gets to England and decides to study English; this will disappoint people at home who had hoped he would go into law, but in any case he should be sure to get a senior administrative job, succeeding some departing expatriate, with all the extra benefits that have gone with these positions.

He remains in England for nearly four years. At a social event of the London branch of the NCNC, the Igbo-related political party, he meets Clara for a brief encounter on the dance floor in which he manages to step on her toes too many times. They do not see each other again until they happen to be on the same boat, taking its time to return them both to Lagos. During that passage, romance begins to flourish.

Clara, of course, is another been-to, and an Igbo. Like many young women who go abroad for training, she has been a nursing student. In fact, the term "been-to" shows up only once in this book, referring to Clara rather than Obi: "You could tell a been-to not only by her phonetics, but by her walk-quick, short steps instead of the normal leisurely gait. In company of her less fortunate sisters she always found an excuse for saying: 'when I was in England ...' (Achebe 1960: 93).

Obi and Clara-a perfect couple, it would seem. There is, however, a big problem. Clara is an osu, a member of a caste-like grouping of descendants of shrine servants in pre-Christian Igbo religion. The osu remain a sort of untouchables, even as the Igbo have become Catholics, Anglicans, or Methodists. Obi wants their relationship to continue and move onward to marriage, although Clara is more doubtful. It does not remain a private matter between the two of them either. Word moves through the grapevine back to Umuofia, where anti-osu prejudice 
remains strong, and Obi's parents are very much against having this prospective daughter-in-law. His mother would rather die first.

Yes, Obi does get a good administrative job, where, for one thing, he is involved in scholarship awards (for the continued production of been-tos). Between dates with Clara, Obi finds time to participate in Lagos nightlife in the company of other reasonably well-to-do Igbo bachelors. He lives comfortably in an apartment in what used to be a residential area for Europeans only, and a steward attends to his domestic needs. He gets a car, too, for his Lagos mobility but also for the occasional long drive back to Umuofia. But his personal finances become messier and messier. People in Umuofia expect him to return their past investment in his education, so that more youths from the town can afford more schooling. There are costs for insurance and for the infrastructure of the life of his extended family, matters of health and education. Consequently, Obi finds himself seriously in debt.

Then Clara finally gives up on the relationship, which she finds financially difficult and socially impossible, but only after a complicated illegal abortion. Obi has lost her, and his mother has died after a long illness. At this point, he gives in to temptation. He has already resisted other attempts to bribe him for the furtherance of particular candidacies for the scholarships that he would handle in his job. This time he accepts a sum, which would help him out of his financial crisis, from someone appearing at his door. But it is a setup, and he is promptly arrested.

There are no real cliffhanger points in No Longer at Ease, for Achebe has placed the ending in the first chapter, describing Obi's court trial and citing the surrounding commentary among Igbo, as well as nearby expatriates, the latter forever inclined to find corruption among the Africans coming in to take over their positions. So the chapters that follow, from an Umuofia boyhood onward, explain what took him to his failure.

Why, in the Nigerian fiction of the mid-twentieth century or so, were the been-tos and their lives so often depicted as problematic-while the tendency in real life was rather to see them as success stories? We might note that the men, especially, were often of the first generation taking over after colonialist expatriates, often inheriting their fringe benefits and the formal or informal control of major public resources. If the most general theme is that of a conflict between modernity and tradition, between universalist principles and more particularist claims of local or kinship loyalties, the specific focusing on the been-to at the center of such loyalties may well have something to do with the fact that so many of the early generation of Nigerian writers were civil servants 
somewhere in bureaucratic structures-hardly themselves strangers to career thinking and the strategic significance of credentialed training in a prestigious "abroad." People such as Cyprian Ekwensi, Chinua Achebe, Onuora Nzekwu, Chukwuemeka Ike-all had desk work during the day. The Onitsha writers, for their part, could see the been-tos as arrogant superiors.

Yet I am also inclined to detect here a more widespread motif in the midcentury commentary on cultures in contact, on what happens in migrations and with people somehow not quite in place. In metropolitan sociology, a body of writings grew around the new concept of "the marginal man." The originator of the concept, Robert E. Park ([1928] 1964: 356), ancestral figure of the powerful Chicago School of sociology, and more concerned than most academics at the time with what we might now term globalization, proposed that "it is in the mind of the marginal man that the moral turmoil which new cultural contacts occasion, manifests itself in the most obvious forms."

Something may have happened, however, between Park's time and ours. Perhaps people like been-tos are now less likely to be seen as tragic? Compare Park with Salman Rushdie (1991: 394), commenting in a well-known passage on that famous and controversial novel of his: "The Satanic Verses celebrates hybridity, impurity, intermingling, the transformation that comes of new and unexpected combinations of human beings, cultures, ideas, politics, movies, songs. It rejoices in mongrelization and fears the absolutism of the pure. Mélange, hotchpotch, a bit of this and a bit of that is how newness enters the world" (italics in the original). There has been a shift toward assertiveness and, indeed, celebration. Impurity and intermingling are a sourceperhaps the most important source-of desirable cultural renewal. Perhaps Wole Soyinka, returning in the late 1950s from his sojourn at the University of Leeds, and quickly engaging in new creative cultural hybridity (while never in a bureaucratic career), has been the most conspicuous pioneer here, taking various kinds of risks along his continued path-more about him in chapter $11 .^{3}$ And later Afropolitans of the kind identified by Taiye Selasi, such as Chimamanda Ngozi Adichie and Teju Cole, may be other examples of how been-tos have come a long way-see chapter 17. 


\section{Notes}

1. Among Egbuna's other books are Wind versus Polygamy (1964), The Minister's Daughter (1975), and Diary of a Homeless Prodigal (1976), variously published in London and Enugu.

2. The Victoria Falls have presumably retained their name to safeguard the tourist business; one may sense a certain irony in this, in some contexts.

3. It so happens that in an interview where Soyinka is asked which novelists he reads, he mentions Rushdie, together with Gabriel Garcia Marquez, Toni Morrison, and Charles Dickens (Wilkinson 1992: 102).

\section{References}

Achebe, Chinua. 1960. No Longer at Ease. London: Heinemann.

Egbuna, Obi B. 1964. Wind versus Polygamy. London: Faber and Faber.

- 1975. The Minister's Daughter. London: Fontana.

- 1976. Diary of a Homeless Prodigal. Enugu: Fourth Dimension Publishers.

- 1980. The Madness of Didi. London: Fontana.

Obiechina, Emmanuel. 1973. An African Popular Literature. Cambridge: Cambridge University Press.

Ogali, Ogali A. 1977. Coal City. Enugu: Fourth Dimension Publishers. Park, Robert E. (1928) 1964. Race and Culture. New York: Free Press.

Rushdie, Salman. 1991. Imaginary Homelands. London: Granta.

Wilkinson, Jane. 1992. Talking with African Writers. London: James Currey. 


\section{CHAPTER 8 \\ Dateline Lagos \\ Reporting on Nigeria to the World}

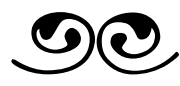

In 1976, John Darnton came to Lagos as a correspondent for the New York Times. ${ }^{1}$ This was his first foreign posting. Starry-eyed, the young journalist would do feature stories on everyday life and urban growth pains: street traffic, the end of the windy harmattan season, the problems of getting a telephone repaired, the influx of expatriates, new buildings coming up, the old canal between Lagos Island and Ikoyi being filled in. Then, about a year later, he was arrested, and a little later expelled with his family. He continued writing from elsewhere in Africa, and later earned a Pulitzer Prize for his reporting from early 1980s Poland. At the time of his expulsion, the Nigerian military government was evidently disturbed by the intended but failed countercoup that resulted in the killing of General Murtala Muhammed, the energetic head of state. So it seemed inconvenient to have foreign newspeople like Darnton around. The immediate cause of government action may have been his interest in the infamous military attack on Fela Kuti's nightlife temple, the Kalakuta Republic.

The coverage of Nigeria by international news media in the late twentieth and early twenty-first century has been, let us say, a mixed success. ${ }^{2}$

There have been other star journalists reporting out of Lagos. Ryszard Kapuscinski, apparently the only foreign correspondent working for the national news agency of Communist Poland for a long period beginning in the 1960s, acquired world fame for his books on the courts of the emperor of Ethiopia and the shah of Iran, and for The Soccer War (1990), a wide-ranging book of essays drawing its title from the strange armed conflict between Honduras and El Salvador in 1969. He claimed to have witnessed twenty-seven revolutions and coups.

As far as Nigeria is concerned, there is a chapter in The Soccer War on an early 1960s election campaign of UPGA, the United Progressive 
Grand Alliance, a Yoruba-based opposition party. In another book of essays, there is Kapuscinski's (2001: 108-117) account of finding housing in central Lagos, in an alleyway where his neighbors are surprised to find a white gentleman standing in line with their children to get to the water pump. A Polish correspondent had much less funding for travel, accommodation, and other expenses than Western European or American correspondents, so he had to seek carefully for a place where he could stay.

Even as it may just about always have been a pleasure to read Kapuscinski, his reporting may have tended to be more poetic than precise. It is also true that he remained overtly loyal to the party at home, while privately less so-as long as the regime lasted, anyway. That meant that, after 1989, he had a past to deal with, and, in the intellectual and political upheavals of post-Communist Poland, commentary on Kapuscinski continued after his death in 2007. ${ }^{3}$

Much of the time, however, international news reporting on Nigeria has been based elsewhere, done from a distance or by way of brief visits. I learned some more about this in the late 1990s and early 2000s as I engaged in a study of the work and life of foreign correspondents, and had Africa reporting as one of my central interests. The main site for this part of my study was in Johannesburg, South Africa. In Richmond, a small suburban enclave a little to the west of central Johannesburg, there were two buildings a couple of minutes apart from one another, where a great many of the foreign news media organizations in Johannesburg had their offices. In one of them I found the Associated Press, CNN, the Los Angeles Times, Newsweek and some others; in the other, rather larger building, there were around twentyfive to thirty media or media-related offices. From those two buildings in Richmond, a very considerable proportion of news out of Africa spread over the world. Many of the news organizations had one "Africa correspondent," in principle responsible for covering some forty-five countries south of the Sahara. Johannesburg was a logical location for the purpose. It was the main city of what for economic and other reasons seemed to be the most important country of the continent. Even if it was far to the south, it had reasonably good air connections, while regular traffic between African countries was otherwise deficient. Johannesburg could also offer comfortable living conditions, not least for those correspondents who had brought their families.

The journalists-whether print, radio, or television people-would certainly travel out of there to other parts of Africa on reporting business. But, as such trips were likely to be expensive, their head offices, wherever they were in the world (mostly Europe and North America), would tend to limit them. The editors and management 
might see the coverage of "hard news" as inevitable, but tended to be unenthusiastic about softer feature stories of various kinds. "Hard news," however, tended to be bad news: about coups, civil wars, epidemics, natural disasters. And so the outside world was offered a somber view of what happened on the continent. "Afro-Pessimism" became a 1990s word. Not that the continent was without problems, but one might ask if the economics of the international news business did not contribute to generating such outside understandings. ${ }^{4}$

Hard, bad news, of course, would tend to be complemented by stories about wildlife. Distant audiences seemed forever interested in elephants and chimpanzees, and giraffes look good in pictures. But this would favor the east and south of the continent, rather than the west.

There is a parody of quick news media travel in Chibundu Onuzo's Welcome to Lagos (2017), describing a British talk show star's journey to Lagos, flying first class alone, with his technicians and makeup artist further back in the plane. He was to interview a Nigerian exminister about a corruption scandal transforming into something like a Robin Hood tale (see chapter 5); knowing very little about Nigeria, he nevertheless had expertise in talking to people.

While in Johannesburg, I was curious about what those roving correspondents could tell me about their experiences in reporting on Nigeria. In fact there was not so much of it. Under the dictatorship of General Abacha, the tendency was to think that the fewer foreign journalists were around, the better-thus, not to let so many of them into the country. Some made their entry on tourist visas, but many would hold this unprofessional, as well as dangerous. The Africa correspondent for the Guardian at the time, Chris McGreal, described how he had flown into the country shortly after the execution of Ken Saro-Wiwa, writer/environmentalist/politician, an event which did call for international attention (see chapter 18). Somehow nobody had checked whether he was really accredited, so he even made his way into an official dinner where Abacha was making a speech, and went on to Ogoniland, Saro-Wiwa's homeland in the southeast. And there the state governor had wondered why so few foreign journalists came to see him-apparently unaware that mostly they were not allowed into the country. To McGreal, this was all an intriguing mixture of despotism and inefficiency.

A little later, on the other hand, international news media people clearly flocked to Nigeria, and this could have unexpected consequences. It was toward the end of the 1990s, as I was engaged in my study of the foreign correspondents, but at home in Stockholm, and watching 
the evening news on CNN International. Then suddenly something unexpected came up. Catherine Bond, an Africa correspondent usually stationed in Nairobi, was on the screen reporting from Kafanchan! Then in a day or two, the New York Times also reported from my Nigerian town.

The emir of Jemaa, Hausa traditional ruler of the area where Kafanchan is located, had died, aged 95-I suspect that his age was really somewhat uncertain and approximate. In fact, his rule had been shaky. His dynasty had arrived in the early nineteenth century as an outlier of the Fulani-Hausa Muslim jihad led by Usuman dan Fodio. It exacted tribute from the local farming populations and took some of their members as slaves. The system of indirect rule introduced by Lord Lugard actually strengthened the power of the Jemaa emirate, as it now also had British support. But then these local ethnic groups in large part adopted Christianity as both an ideology and an organizational resource in resisting Muslim domination, and, by the 1990s, they were certainly expecting that when the old emir died, that would be the end of the emirate. Yet now, suddenly, it was announced that his son would succeed him in the office. Locals rose in violent protest. The emir's palace had been set afire, and the new emir had fled. The uprising had caused a number of deaths.

This could indeed seem like something worth reporting on, but I suspected that the international news attention to Kafanchan was a case of serendipity. After the long period of dictatorship under General Abacha (who had recently died under mysterious circumstances), Nigeria was returning to civilian rule. And the newly elected president was just taking up office, so members of the world news media gathered for the event in Abuja. Then, as one of its last actions, the departing military junta had decided to let the Jemaa emirate continue in power. At least some of the media people heard of the resulting unrest, a few hours' drive away, and hurried over there. I doubt that either CNN or the New York Times have reported from Kafanchan since then.

Then for some time there was Boko Haram (trans. "Ban Western education"), and especially its kidnapping of a few hundred teenage girls from a boarding school in Chibok- "the Chibok girls," drawing the attention of the world to Nigeria. The Bring Back Our Girls campaign had the support of First Lady Michelle Obama, as well as Nobel Peace Prize laureate Malala Yousafzai.

But again, some of the reporting was by Africa correspondents in Johannesburg. Other newscasts were from Lagos, in the southwest corner of Nigeria, about what was happening in the northeast (particularly in the state of Borno). It irritated me repeatedly that on radio 
and television, there were all those references to Maiduguri-not Maiduguri. One might think that was a minor nuisance, the reaction only pedantry on my part, but it suggested that the reporters had not spoken to anybody with local knowledge. They relied entirely, it seems, on written sources on the web, which taught them nothing about pronunciation.

After some years, finally, came the small book The Chibok Girls by Helon Habila (2017). Habila's probably best-known, acclaimed novel, Oil on Water (2011), is a tale of the troubled Niger Delta, with the oil industry and government troops on one side and local armed rebels on the other. ${ }^{5}$ It is the lively story of the presumed kidnapping of the wife of a British oilman, as seen through the eyes of a young Nigerian reporter trying to cover that story. So this was journalism in fiction, dateline Port Harcourt, on violence in the southeast of the country. The Chibok Girls was nonfiction journalism in the violent northeast, dateline Maiduguri.

Habila's reporting on Boko Haram could draw on the fact that he knew the area. He was a member of the small Tangale ethnic group, the son of a Christian preacher, and had his childhood in the city of Gombe, not very far from Chibok. Gombe was the capital of a Muslim emirate, so Habila grew up surrounded by Muslims. But it was also in the border area of what has been known, in politico-cultural terms, as the Middle Belt of Nigeria, in large part Christian and opposed to the Muslim domination of that North, of which it was somehow also a part. (In fact, Kafanchan and its surroundings, a considerable distance away, shared much of the same nineteenth- and twentiethcentury history.) So Helon Habila understood Chibok, which was another Christian enclave in the North, and could portray both it and Maiduguri insightfully, as well as colorfully. In Maiduguri, he could talk in Hausa to his taxi chauffeur, member of a trade that is often a first source of information to fly-in foreign correspondents; but he could even detect the Kanuri accent. The Kanuri are the largest ethnic group in Borno State. Habila discovered, too, that the view of the problems of modernity held by this driver were not so different from that of Boko Haram. ${ }^{6}$

He could also talk to some of those Chibok girls who had escaped, in Chibok. They remembered that their Boko Haram captors had called them infidels and prostitutes. Now they wanted to go to the university and become doctors.

Helon Habila, of course, was not quite a "foreign correspondent." The Gombe childhood clearly helped his entry into the Boko Haram 
world and its local counterworld. However, when he published his report, he was an associate professor of creative writing at George Mason University in suburban Virginia, outside Washington, DC.

\section{Notes}

1. I draw for this paragraph on the Wikipedia article on John Darnton, and on two of his New York Times articles (Darnton 1976, 1977). In chapter 9 we turn to a novel by his wife, Nina Darnton, drawing on her Lagos experience. The prominent (and anthropologically inspired) historian Robert Darnton, specialist on French cultural history, is John Darnton's brother. Later on, it seems to have been another New York Times correspondent, Norimitsu Onishi (2002), who coined the term "Nollywood" for what was to become one of the world's largest movie industries. It was also Onishi (1999) who reported from Kafanchan, in an article referred to later in this chapter.

2. One of the most successful reports on Nigeria, a long step away from dayto-day coverage, is Karl Maier's This House Has Fallen (2000)— the title is a quote from Chinua Achebe-appearing after the end of the difficult 1990s and the Sani Abacha regime. Maier was Africa correspondent of the Independent, the London newspaper. Kafanchan and its surroundings are briefly portrayed in the book as well.

3. A review of Kapuscinski's life and work by his friend Artur Domoslawski (2012) itself became a bestseller, and earned an English Pen award.

4. Some twenty years later, international reporting would seem not so entirely Afro-Pessimist. Dayo Olopade, Nigerian-American journalist with three degrees from Yale University and a record of reporting to a variety of American newspapers and journals, has a hopeful book describing her beat (including Nigeria): The Bright Continent (2015).

5. In a later novel, Travellers (2019), Habila takes his readers to Europe and tells of encounters among refugees, exiles, students, artists, and others of varying African backgrounds, in Berlin, Basel, London, etc. Nigeria and Nigerian identities appear marginally here, although at the end a refugee with a particularly dismal path through life reminisces in a written note about his experience of a terrorist movement, which is obviously Boko Haram.

6. On Boko Haram and the Chibok girls, there is also a book by Isha Sesay (2019), sometime CNN reporter of Sierra Leonean background. And there is Edna O'Brien's novel Girl (2019), the first-person narrative of a young female, captured and prematurely forced into motherhood and adulthood, then escaping and finding a new life with her baby daughter; a book remarkably based on field studies in Nigeria by the author, then in her late eighties. While she may not have been in the Boko Haram heartlands, the acknowledgments at the end of the book show that she has been to Abuja and to Jos, and to Fulani camps in Kaduna State. She had found informants as well in the Nigerian Houses of Praise scattered 
through London. In fact, the term "Boko Haram" appears nowhere in the text, where the movement is referred to only as "the jihadis." But in the acknowledgments and on the front cover flap, the Boko Haram reference is explicit.

\section{References}

Darnton, John. 1976. "Winds Gone, Rains Due, an Unsettled Mood Hangs over Lagos." New York Times, 17 April.

1977. "Nigeria Arrests, Then Expels the Times's West Africa Correspondent." New York Times, 14 March.

Domoslawski, Artur. 2012. Ryszard Kapuscinski: A Life. London: Verso.

Habila, Helon. 2011. Oil on Water. London: Penguin.

- 2017. The Chibok Girls. London: Penguin.

2019. Travellers. New York: Norton.

Hannerz, Ulf. 2004. Foreign News. Chicago: University of Chicago Press.

Kapuscinski, Ryszard. 1987. Another Day of Life. New York: Harcourt Brace Jovanovich.

1990. The Soccer War. London: Granta.

2001. The Shadow of the Sun. New York: Knopf.

Maier, Karl. 2000. This House Has Fallen. New York: Public Affairs Press.

O'Brien, Edna. 2019. Girl. London: Faber and Faber.

Olopade, Dayo. 2015. The Bright Continent. Boston: Houghton Mifflin Harcourt. Onishi, Norimitsu. 1999. "New Leaders Face a Violent and Splintered Nigeria." New York Times, 10 June.

2002. "Step Aside, L.A. and Bombay, for Nollywood." New York Times, 16 September.

Onuzo, Chibundu. 2017. Welcome to Lagos. London: Faber and Faber.

Sesay, Isha. 2019. Beneath the Tamarind Tree. New York: HarperCollins. 


\section{Death in Lagos}

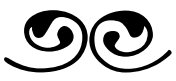

It seems I share with many of my anthropological colleagues a taste for detective stories, and I think there is a particular kind of affinity involved. It is not that we choose this sort of fiction so much for literary qualities, which these stories may or may not have, but rather that we turn to them as another, more relaxed, kind of studying sideways. These stories may to a degree resemble our field situations: we may get to know a certain number of people reasonably well, but around them there is also a wider setting providing a sense of place. It is also true that mystery writers and anthropologists have increasingly converged on urban scenes. Sherlock Holmes with his Baker Street address may at one time have been rather unusual, when more writers set their stories in somewhat remote, otherwise idyllic settings. (Fieldworking anthropologists used to be village people too.) Now Sara Paretsky takes us to Chicago; Linda Fairweather, to New York; George Pelecanos, to Washington. These are complex, unpredictable placesless transparent, with more anonymity.

It is also true that detective stories have gone global. ${ }^{1}$ When I feel like traveling in my reading (which, perhaps also for other anthropologists, is most of the time), detective stories can take me to Venice, Istanbul, Vientiane, Shanghai, or Tokyo-sometimes entailing time travel into the past as well. For a visit to West Africa, I can choose the company of Afropolitan (Ghanaian-Californian) Kwei Quartey, and learn about Accra in his Children of the Street (2011). ${ }^{2}$ If I want to stay home, as a Stockholmer, I can turn to the strikingly successful "Millennium Trilogy" of Stieg Larsson.

Where has Nigeria figured in this genre? Nowhere particularly prominently, as I understand it. True, genres can be more or less blurred, so it may be that there are elements of mystery in some wellknown novels. It is not that Nigerian authors have stayed away from 
it either-in Wendy Griswold's (2000) overview of Nigerian fiction, she classifies about a hundred novels, out of a total of 476, as belonging in a crime genre. Yet she does not have all that much to say about them. They seem to find readers (and publishers) at home, but may be mostly forgettable.

But Lagos is no idyll. On my shelf I find Bloodbath at Lobster Close, by Dickson Ighavini (1980), in Macmillan's Pacesetters series devoted to African authors. "Lobster Close" is in a well-to-do suburb of a city named Portkano-but since it is a capital city, with foreign embassies, in a country where more or less shady petroleum deals are a major business, and with key people having more or less recognizably Nigerian names, Portkano can hardly be anyplace but Lagos. Frank Jirinde, a successful businessman, lives with his family at Lobster Close. He is threatened on the phone; a young child of his is kidnapped; police officers at various levels are involved, as well as the local criminal hierarchy. But two important persons are expatriates. One is a criminal of British-Lebanese heritage, with a past as a soldier of fortune here and there in the world's conflicts. The other is Jirinde's wife-and it turns out rather late in the story that this sensible, heroic woman is British by birth. (The author may have been pleased with this surprise element in the text, but since there is a young white woman with Black children on the cover of the paperback book, the reader may have got the idea rather earlier.)

Bloodbath at Lobster Close is a rather short book, certainly actionpacked, but there is not much vivid portrayal of either key persons or the urban setting. It hardly stands out as a very significant contribution to the genre. Soon after, Dickson Ighavini wrote a couple more books, which I have not read, and I find no traces of a continued writing career.

Cyprian Ekwensi makes an even briefer early excursion into the crime story genre, with Yaba Round-about Murder (1962) fitting into his other Lagos writings. This one is fifty-five pages long, really a pamphlet, locally published.

Another mystery story is explicitly set mainly in Lagos, although the author is American, not Nigerian. The novel is An African Affair, by Nina Darnton, published in 2012. Darnton lived in Lagos in the 1970s as the wife of John Darnton, the New York Times correspondent referred to in chapter 8 , and while the precise period in which her story is set is vague, some signs point in this direction. There is a ruthless military dictatorship, with its headquarters at Dodan Barracks, Lagos-there is no capital at Abuja yet. The occasional reference to Internet use, on the other hand, does not fit with that. 
The story is more developed than Bloodbath at Lobster Close, in style and in plot. But while it is placed in Nigeria, Nigerians actually play a limited role in it. The journalist heroine is Lindsay, visiting correspondent from the New York Globe, and the people surrounding her are in large part other foreign correspondents and diplomats (including intelligence services). Their sociable exchanges are not local Nigerian gossip, but the gossip of the Africa newsbeat:

We just got back from Zaire. Incredible. Kinshasa is still the same scary place. You remember Gabe Weston from the LA Times? He hid in the hotel the whole time. He kept coming up with phony reasons not to come with us. Wrote his piece from the bar at the Continental. The rest of us tried to get by the military blockades and talk to villagers about the Australian stringer who disappeared. (Darnton 2012: 31)

These, then, are expatriates in safari suits, not longtimers in Nigeria, and in large part based in the affluent quarters of suburban Ikoyi, next to major embassies. ${ }^{3}$ At Ikoyi Club, a rather run-down vestige of colonial times, they will encounter those wealthy locals who "somehow had managed to remain anglophiles-so brainwashed that even now, more than three decades after independence, they thought anything British was the height of sophistication" (2012: 128). (That would place the story in the 1990s.) Lindsay's steward refuses to call her by her first name instead of "madam."

Central Lagos becomes visible mostly in traffic jams. As newspeople and diplomats, however, these expats are intensely interested in the Nigerian political scene. There is an energetic opposition seeking a return to civilian rule, and a series of murders, and there are rumors of coups and countercoups, and one real coup; the Nigerian NorthSouth divide is necessarily an ingredient here. On the other side of town, in rather rundown Surulere, there is an establishment named the Juju House, the entertainment compound where Bayo Awollowa Soti, mostly just known as Bayo, lives with some twenty beautiful young wives, plays his celebrated Afro-beat on his saxophone, and also engages in radical politics. Surely a close-enough portrait of Fela Kuti and his Afrika Shrine. In the novel Bayo dies, however, of a heart attack as soldiers are taking him to the prison after having burned down Juju House. A bit later, Bayo's next in command is killed.

One of Lindsay's new friends, with headquarters in London and New York, deals in African arts, mostly carved wood sculptures, so he can tell her about Yoruba ibeji twin figures. Moreover, he takes her on an excursion to Osogbo (not an entirely safe trip, as there are road bandits), quite far into Yorubaland, where they meet an expatriate 
of Austrian background, who has in her own way "gone native": the sculptress-batik artist-priestess Roxanne Reinstadler. Darnton's model for this figure is obviously Susanne Wenger, the real-life Austrian famously based in Osogbo (see chapter 6). Lindsay can get a good feature story out of the meeting with Roxanne if she can only manage to file it on time. Keeping in touch with the New York office from Lagos is just about always a problem.

So a web of mystery is woven. The expatriates turn out not always to be what they at first seem to be. Who knew what about whom, and when? Petroleum and drugs are what much of the game is about, involving successive dictators as well. There are rumors of mercenaries, assassination managers from Solutions Incorporated. Even Darnton's title, An African Affair, has a double meaning. As the story ends, Lindsay is back in Europe, trying to figure out what her life and her career are coming to.

Another expatriate journalist character, Guy Collins, offers the firstperson narrative in Easy Motion Tourist, the debut thriller by Leye Adenle (2016, published by Cassava Republic Press). No uncertainty about the period here: this is definitely twenty-first-century Lagos. Well over a half century after Cyprian Ekwensi's depiction of the seamy side of city life, it has all become so much more glaring: enormously wealthy (but poverty-stricken next door), enormously corrupt, enormously promiscuous, whether on a cash basis or not. Much of the action takes place on Victoria Island, which the Nigerian and expatriate elite would much like to have to themselves as a sort of giant gated community, and so there is great anxiety when the word is out that some sort of a ritual murder of a young woman (evidently a prostitute) has taken place there. For one thing, they do not want international media attention.

That journalist Collins, however, is an Englishman working for British news radio. Occasionally he tries to present himself as a BBC correspondent for the sake of prestige, but this is not really true. $\mathrm{He}$ has been sent out by a modest news site on the Internet, to cover an upcoming election, and happens to be on site, coming out of a nightclub close to the Eko Hotel where he has stayed, around the moment when that murder is discovered. Consequently, he may become a convenient suspect. Having been placed under arrest, however, he is rescued from a prison cell by the heroine of the story, Amaka, lawyer and tough, smart activist for Street Samaritans-an organization that does not so much aim to get prostitutes to leave their trade as to try and keep them safe.

The Lagos scene has bandits named Catch-Fire, Go-Slow, and Knockout; there is the police officer Hot-Temper as well. They are all in 
the plot. Kalashnikovs, Uzis, and AK-47s are their tools. Not so much depth perhaps, but action, action, action (divided into 61 chapters).

After a brief encounter in bed, Guy Collins becomes quite attached to Amaka. His editor orders him back to London, as the election he was supposed to cover no longer seems terribly newsworthy. But Guy is catching on to another, better, story by way of Amaka. He gets quite worried when he learns that she has gone to see one extremely wealthy businessman, ostensibly to beg for a donation to Street Samaritans, but really to find out where that wealth comes from. A friendly exchange, with lunch provided by the host's private Chinese cook, and at which the host hints at amorous intentions, ends with a dose of chloroform. Amaka loses consciousness. Guy, knowing where she is, goes there with a local collaborator to rescue her, but they get stuck in a traffic jam for a long while.

That host-turned-enemy decides it is time to escape-by air, to a hideout in Accra, although he tries quickly to spread the word that he is going to the United States to see family members. Guy and his partner catch a glimpse of his car as it leaves, and follow in his tracks as discreetly as they can, into a slum, where the millionaire has his bandit following. He unloads Amaka's unconscious body from the car trunk and takes it into the gangsters' house. Guy and his partner, whom he had thought was a local journalist but who turns out to be a policeman in disguise, follow them into the house, where somehow more police also turn up. There is a shootout, where Amaka and Guy are among the survivors. That millionaire, on the other hand, who has indeed been in a lucrative trade in body parts, is killed. It is time for Guy to catch his flight to London, but as he and Amaka kiss each other farewell, it is clear that they both expect to see each other again.

Nnedi Okorafor's Lagoon (2014) is again definitely a work of the present, but only uncertainly in a crime genre. Okorafor is an Afropolitan, professor of creative writing at the University of Buffalo (part of the State University of New York). It originated as a screenplay for a Nollywood movie, and then became at least as lively as a book. The two central figures are women: Adaora, a marine biologist and Igbo, with her family home and her own aquatic laboratory only minutes from Bar Beach (again, on Victoria Island); and Ayodele, who emerges from the sea and quickly acquires a Yoruba name. But Ayodele is actually extraterrestrial, amphibious, forever shapeshifting.

There are other people more or less continuously involved in the story: a Ghanaian star rapper; a Nigerian army soldier; Adaora's husband, Chris, an affluent jet-hopping accountant in international business who has a German MBA degree and who has also become 
a born-again Christian (and thinks Ayodele is a marine witch); Chris' mother, a forever-meddling, trouble-making mother-in-law; Father Oke, a self-made bishop with his congregation mostly in the street (but with Chris as a generous donor); and a reporter for the Nigerian Times who has been a sometime CNN correspondent. At least in Adaora's memory, there is the rather improbable figure of a Tuareg expert diver from the Sahara desert. Rather late, the president of Nigeria also turns up, with two of his three wives. He has just returned from life-saving heart surgery in Saudi Arabia; he had been worried that he would have to turn over his high office to the vice-president, Wishwell Williams, whom he saw as a money-grubbing Christian blockhead with a stupid name. ${ }^{4}$

Several of these people happen to meet on that beach:

In many ways, Bar Beach was a perfect sample of Nigerian society. It was a place of mixing. The ocean mixed with the land and the wealthy mixed with the poor. Bar Beach attracted drug dealers, squatters, various accents and languages, seagulls, garbage, biting flies, tourists, all kinds of religious zealots, hawkers, prostitutes, johns, water-loving children and their careless parents. The beachside bars and small restaurants were the most popular hangout spots. Bar Beach's waters were too wild for any serious swimming. Even the best swimmers risked a watery death by its many rip currents. (Okorafor 2014: 7)

"A perfect sample of Nigerian society"? No hard-working farmers, no Fulani pastoralists here. Once more, rather more a sample of Lagos. Yet as we move off the beach, we encounter other groups and settings as well: the pioneer LGBT movement Black Nexus, an Internet café where most of the customers seem to engage habitually in their infamous "419" financial scams with victims abroad, and the Area Boys, street children grown into teenagers waiting for the sunset, after which their criminal activities can proceed even more freely. ${ }^{5}$

Scenes shift rapidly between fifty-seven brief (sometimes extremely brief) chapters, rather like in Adenle's book. It is at Bar Beach that Ayodele comes out of the water. Apparently, she had been a swordfish a moment earlier, and then continues to take on different forms-at one point, a green lizard.

Long before that, however, it has become clear that Ayodele did not come alone. She belongs to a band of extraterrestrials with uncertain intentions and different guises. As they arrive with an eruption in the sea and then a threatening series of tidal waves, chaos reigns in Lagos. People try to escape to their home villages or by plane overseas, but the latter turns out to be impossible, as the airport closes down.

Fisayo, smart secretary in an office by day, finding her customers as a high-class Bar Beach prostitute by night, witnesses aliens coming 
ashore, and decides to resist the invasion-with texted signs and with a gun. When she sees Ayodele in a crowd, she shoots her, but Adaora, who is also there, observes that Ayodele turns into a mist. And then Fisayo somehow fades away and is forever gone. Ayodele has pulled her apart at a molecular level.

Fisayo shooting Ayodele is one of few instances of real violence in Lagoon. Otherwise, people sort of die or disappear, if they have not turned into something else. Father Oke, the bishop, meets Mami Wata at the beach, then vanishes walking into the ocean. Ayodele finally becomes a smoke, turning into a fog spreading over Lagos, with the attractive smell of garden eggs (a popular, small local variant of eggplant, or aubergine). With this farewell, things seem to take a happy turn. The president goes on television to address the nation, speaking out against corruption and other social evils.

Lagoon ends with a set of reading group questions (as befits a book by a professor of creative writing). One of them goes as follows: "Should Lagoon be categorized as science fiction, fantasy, African literature, American literature, Nigerian literature, Naijamerican (NigerianAmerican) literature, magical realism, thriller, suspense, literary, or something else? Why?"

Good question. Perhaps it is a genre-defying book that Amos Tutuola would have enjoyed? One may be reminded, too, of arguments over where to place Ben Okri's The Famished Road (1991) in the literary order of genres. In any case, somebody might do a dissertation on the recurrent appearances of mamiwatas ("mammy-waters," mermaids) and madmen in Nigerian fiction-both representatives of uncertainty. The madmen show a certain resemblance to the varieties of street preachers, such as Father Oke. And the extraterrestrial Ayodele is not entirely unlike a mamiwata, although she can take on other shapes as well.

We could give some thought, too, to the fact that Nina Darnton, Leye Adenle, and Nnedi Okorafor all have women as key figures in their books, yet not really of the policewoman/detective heroine type we find elsewhere in the genre-with Sara Paretsky in Chicago, for example. In Stockholm, Stieg Larsson's Lisbeth Salander, as a trickster figure, perhaps becomes a little like Ayodele. But given the role of successful, strong, enterprising women in Nigerian business, one could imagine the possibility of creating a local detective heroine.

Of course, not all Nigerian detective stories have to be set in Lagos, however much that may attract the imagination. Why not a mystery in Kano, with the hero/heroine problem-solver moving, in some period, between the walled Old City and the sabon gari, the migrants' quarter? 


\section{Notes}

1. On the globalization of crime fiction, see Nilsson, Damrosch, and D'haen 2017. I have commented on the affinity between ethnography and detective stories in another context (Hannerz 2013).

2. Quartey's books are with a major New York publisher, and evidently intended in large part for an American market. The fact that paperback editions carry review blurbs from magazines such as Ebony and Essence suggests that Black Americans are expected to take some special interest in them.

3. Decades earlier, in No Longer at Ease, Chinua Achebe (1960: 18) offered his view of Ikoyi: "For all its luxurious bungalows and flats and its extensive greenery, Ikoyi was like a graveyard. It had no corporate life-at any rate for those Africans who lived there. They had not always lived there, of course. It was once a European reserve. But things had changed, and some Africans in 'European posts' had been given houses in Ikoyi." And this is Cyprian Ekwensi (1961: 51) about Ikoyi, as seen through the eyes of Jagua Nana: "The Government Reservation where the white men and the Africans high up in the civil service lived. Ikoyi where the streets were straight and smooth, where they played golf on the open sands: a reservation complete with its own police station, electricity base, motorboat beaches, a romantic place."

4. "Wishwell Williams" could possibly remind us of Goodluck Jonathan, a Southern vice-president who ascended to the presidency with the death, after long illness, of a Northern president.

5. For an extended discussion of "419" scams, see Daniel Jordan Smith 2007: $28-52$.

\section{References}

Achebe, Chinua. 1960. No Longer at Ease. London: Heinemann.

Adenle, Leye. 2016. Easy Motion Tourist. Abuja: Cassava Republic Press.

Darnton, Nina. 2012. An African Affair. London: Plume/Penguin.

Ekwensi, Cyprian. 1961. Jagua Nana. London: Hutchinson. 1962. Yaba Round-about Murder. Lagos: Tortoise Series Books.

Griswold, Wendy. 2000. Bearing Witness: Readers, Writers, and the Novel in Nigeria. Princeton, NJ: Princeton University Press.

Hannerz, Ulf, 2013. "A Detective Story Writer: Exploring Stockholm as It Once Was." City \& Society 25: 260-270.

Ighavini, Dickson.1980. Bloodbath at Lobster Close. London: Macmillan.

Nilsson, Louise, David Damrosch, and Theo D'haen (eds.). 2017. Crime Fiction as World Literature. New York: Bloomsbury.

Okorafor, Nnedi. 2014. Lagoon. London: Hodder \& Stoughton.

Okri, Ben. 1991. The Famished Road. London: Jonathan Cape.

Quartey, Kwei. 2011. Children of the Street. New York: Random House.

Smith, Daniel Jordan. 2007. A Culture of Corruption: Everyday Deception and Popular Discontent in Nigeria. Princeton, NJ: Princeton University Press. 


\section{CHAPTER 10 \\ Tai Solarin \\ On Colonial Power, Schools, Work Ethic, Religion, and the Press}

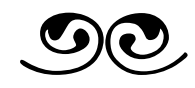

I came across Towards Nigeria's Moral Self-Government somewhere in Lagos in 1961, a slim paperbound book (less than a hundred pages) with an orange cover, the name of the author printed diagonally in red across it: Tai Solarin. Inside the book, I learned that it had been published by the author, at Mayflower School, Ikenne, in 1959.

The next year I met Tai Solarin when he came to Stockholm as a member of a visiting group of Nigerian educationists. He wrote a graceful dedication in my copy of his book, and I enjoyed taking him to lunch at Gyldene Freden, "The Golden Peace," in the Old Town of Stockholm, a venerable place controlled by the Swedish Academy (and named after the conclusion of an eighteenth-century Swedish war). We had our meal downstairs in the ancient cellar, with candlelight. Solarin's coat was of an interesting cut, with wide lapels of a kind not seen in recent decades. He explained that he had not had occasion to wear it since the 1940s, when he had been a student in England. During that period, for that matter, he had also made an excursion to Sweden, earning some pocket money by helping a farmer outside Stockholm with the potato harvest. Since then, the coat had been carefully stowed away with moth balls.

The next year I was back in Nigeria again and was able to visit Tai Solarin in Ikenne, where he ran the Mayflower School, his own coeducational secondary school, with the help of his British wife, Sheila. Ikenne was just off the main Lagos-Abeokuta road, so it was easy to get there. It happened to be the time when the young applicants for a place at the school for the coming year were being interviewed. Tai was perhaps inclined to be generous, but Sheila could be more 
down-to-earth: one girl, she pointed out, was really too physically welldeveloped to be of the age she claimed. There was some other visitor to the school at the same time as I was there, and Tai reminisced about our Stockholm lunch. We had eaten in an old basement, he told his guest, and evidently there was no electricity, since we had to eat by candlelight. So much for the aura of antiquity. Tai was a modernist.

Towards Nigeria's Moral Self-Government is not a literary work, although striking formulations are scattered through it. It is a text by a social and cultural critic, and to a degree the memoir of a man in his mid-thirties, fairly recently back in Nigeria after a decade in Britain, where he had served in the British Air Force during World War II before going on to higher education. Coming off the Elder Dempster Lines ship in Lagos, he hurries to meet his mother, eightyish, small in stature, burdened by having lost a number of close relatives while he has been away. His tears can hardly stop flowing. She, for her part, is suspicious that someone among the many well-wishers showing up to greet him may actually harbor other intentions toward her bintu (been-to) son.

In his book, Solarin offers a late 1950s polemic against the British colonialism soon to go away, but also against the Nigerian society that it had bred. Expatriate officers were often arrogant in the top layer, and uncommitted, not particularly competent, and generally mediocre at the lower levels. But if they still came to serve as role models for incoming Nigerian bureaucrats, it was in large part by showing no inclination to do any manual work.

Solarin, appearing again and again in pictures wearing khaki shorts, preaches a work ethic. During his years in England, for sure, he saw British people not averse to doing practical work. In that overseas period, too, he once took the long train ride from Haparanda, a Swedish border town near the Arctic Circle, through Finland to Helsinki in the south. And, to his surprise, he saw only women staffing the train. Why? he wondered. Well, this was not so long after the end of World War II, where a war between Finland and the Soviet Union had been one of the outliers. Finland lost a great many men there-and then, as loser in the peace settlement, it had been saddled with a large debt to Stalin's country. Now the able-bodied men were busy with other work in order to pay that debt within the time limit set. Against all odds, it met the deadline. Solarin, reminiscing, saw that as an example of what a country can handle with a hard-working citizenry.

Closer to home, he would dwell on the problems with Nigerian schools. As he arrived back from abroad, he had taken on the job as principal of Molusi College, a school in his home area. He had been 
attracted by the fact that it was a community-based institution, not affiliated with any of the Christian missions, which ran so many schools in Nigeria. So he saw a chance to run it more along his own independent mind. But soon organized Christianity moved in on him, trying, for example, to force pupils to attend religious services of one kind or other. It all ended with Tai Solarin resigning — and moving on to set up his own school, the Mayflower School. In the first issue of a school magazine produced by its students, he described what would be the religious stance at Mayflower: the library would stock the Koran, the Bible, the holy text of the Bahá'í, and books on Buddhism, Taoism, and Confucianism.

Organized Christianity, as Solarin saw it, was on the retreat in Europe. Africa seemed to be its last stronghold. (It turns out he had already discussed some of this in a pamphlet titled Our Church in 1984.) Now it was responsible for much of what was out of date in Nigerian schools: not only mandatory religious instruction, but also teaching Latin and Greek-not particularly useful. Solarin would look back at the life of that old mother of his, and see how Christianity had made her unfree in its own way. While he offered religious freedom of choice at Mayflower School, his own thought could perhaps best be described as agnostic. He noted that the Birom ethnic group of the Jos Plateau appeared to be the only people in Nigeria "with no obvious sacred altars," no shrines, and so he went on an excursion to the Birom, accompanied by a Hausa interpreter. At the end of a long talk, he asked his Birom interlocutor what he thought about those world religions. "A plague upon both their houses! . . Can people not live outside Christianity and Mohammedanism?" The Birom, Solarin concluded, were the most courageous people in Nigeria. ${ }^{1}$

Then, rather far from the Birom, Solarin devotes a chapter to his vision of the press. All things considered, among the Nigerian newspapers he favored the Daily Times, despite the fact that it was British-owned and hardly independent of British interests. But its local competitors-the West African Pilot, the Daily Service, the Nigerian Tribune - were all so slavishly aligned with political parties that there was little of independent journalism. The Daily Times at least stood a little bit above all that infighting. Yet what he would really like to see would be a paper he imagined as The Nation-perhaps inevitably owned by the government, but run independently much like University College Ibadan. (We might now describe it as "public service.") It would do its own impartial reporting, and at the same time be open to contributions and letters to the editor from all points of view. There would be articles by well-known scholars. It would cover foreign news. 
Hardly any existing Nigerian newspaper did that in any serious way. The Nation would be the house organ for readers in Kaura Namoda, in Maiduguri, in Yola-everywhere in the country.

Towards Nigeria's Moral Self-Government ends referring to a statement by Obafemi Awolowo, premier of the Western Region, at a constitutional conference in London just before the coming of national independence, forecasting continued close, friendly links with the empire-turningcommonwealth. ${ }^{2}$ Solarin, somewhat disapproving, notes that Awolowo conformed diplomatically to the occasion, but as for himself, he says, "People of my sort are not diplomatic. They speak with all fire and gusto, the throb of their hearts, and let diplomacy go hang."

So much for the book-but Tai Solarin would continue undiplomatic, in varied ways. He could offer his opinions as a columnist in "Thinking with You" pieces in the Daily Times. One may want to describe him as one of Nigeria's leading public intellectuals, although Wole Soyinkaas he reminisces in The Man Dies about being under arrest in Lagos in 1966, after the second military coup, and being questioned about his contacts-cites this exchange between his interrogator and himself:

"I see. So who are the intellectuals you approve of? People like Tai Solarin I suppose?"

"Tai does not claim to be an intellectual. He is a dedicated and selfless social reformer whose thinking is original but sometimes confused. The country could do with a lot more confused but original thinkers like Tai."

(Soyinka 1972: 35)

Then in Soyinka's (2006: 223) You Must Set Forth at Dawn, Tai Solarin appears again, as one of the activists pursuing a scandal in the federal Ministry of Petroleum, occurring when one Muhammadu Buhari had been the responsible minister. It was officially declared that nothing untoward had happened, no funds had disappeared. But a little later, after General Buhari staged his New Year 1984 coup d'état, he promptly had Solarin arrested-“for distributing leaflets calling for a return to democracy." This time, writes Soyinka, Solarin was for a time in a Northern prison, denied access even to his special asthma medicine.

In his Who's Afraid of Wole Soyinka?, a wide-ranging set of reports drawing on his work on African human rights issues for the journal Index on Censorship, Adewale Maja-Pearce (1991: 45-54)—more about him in chapter 18-mentions in passing a 1989 Lagos conference critiquing the structural adjustment policies of the International Monetary Fund, with Tai Solarin as one of the speakers; this was during the period with Ibrahim Babangida as military head of state. Together 
with a veteran trade unionist, Solarin was seized by soldiers sent by the government, who wanted no such conference. He was released later in the day. A radical lawyer also involved in organizing the meeting was taken away in a military aircraft. Once more, these were times when activists could have some bad experiences.

Teju Cole (2014: 53-54) has a favorable couple of pages about Solarin in Everyday Is for the Thief, as a bright Lagosian boy turns out to be attending Mayflower School: "Solarin was a maverick . . . [and] many Nigerians continue to hold him in highest esteem."

Tai Solarin died in 1994, during the dictatorship of General Sani Abacha. There were obituaries in the New York Times and elsewhere. In 2005, the Tai Solarin University of Education in Ijebu-Ode (not so far from Ikenne) became the seventy-sixth officially recognized university in Nigeria. In 2007, Queen Elizabeth awarded Sheila Solarin an MBE, a Member of the Most Excellent Order of the British Empire. Still residing in Nigeria with her family, Sheila died in 2012.

Recalling my long-ago lunch with Tai Solarin, as I took Lorand Matory, the American anthropologist, and his Nigerian wife, Bunmi, on a walking tour of Stockholm's Old Town about a half century later, I pointed to the restaurant Gyldene Freden and asked if they knew of Tai Solarin. "An icon!" they exclaimed.

\section{Notes}

1. In the long run, it is true, like most of the sedentary, mostly farming minority peoples in the middle regions of Nigeria, the Birom tended to turn to Christianity. They show up again briefly in chapter 18. For an anthropological study of the Birom based on field research in the early 1960s, see Smedley 2004.

2. It so happens that Obafemi Awolowo was himself born in Ikenne, later to become the site of Tai Solarin's school, in 1909. His autobiography Awo, published in the year of Nigeria's achievement of independence, offers glimpses of growing up and becoming an adult in colonial Nigeria, and detailed coverage of political struggles, with strong ethnic components, in the late colonial period (Awolowo 1960).

\section{References}

Awolowo, Obafemi. 1960. Awo: The Autobiography of Chief Obafemi Awolowo. Cambridge: Cambridge University Press.

Cole, Teju. 2014. Every Day Is for the Thief. New York: Random House.

Maja-Pearce, Adewale. 1991. Who's Afraid of Wole Soyinka? Oxford: Heinemann. 
Smedley, Audrey. 2004. Women Creating Patrylyny. Walnut Creek, CA: Altamira Press.

Solarin, Tai. 1959. Toward Nigeria's Moral Self-Government. Ikenne: Mayflower School.

Soyinka, Wole. 1972. The Man Died. London: Rex Collings. 2006. You Must Set Forth at Dawn. New York: Random House. 


\section{Wole Soyinka, Leo Frobenius, and the Ori Olokun}

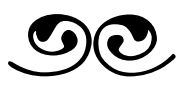

The Nobel Prize in Literature 1986 was awarded, according to the official statement, to Wole Soyinka, "who in a wide cultural perspective and with poetic overtones fashions the drama of existence." I remember listening to the live reporting from the Stockholm ceremony on my car radio, including the fact that the awardee, on stage, just after receiving the prize in his hands from the Swedish king, had made a symbolic gesture, an unusual departure from the conventional ritual, as if pouring libation.

Some years later, he was back for the Nobel Prize festivities again, this time as a guest when his friend, the African American novelist Toni Morrison, was the prize winner. I was also at the prize banquet that year, and after the dinner I noticed him standing alone on the sideline (easily recognizable, with what has been described as his "snow-white Afro"), watching the Europeans dancing. I approached him, and we had a brief chat-he might not have expected on this occasion to run into somebody reminiscing about Kafanchan.

Then several years later again, after the 2016 American presidential election, I could see in the papers that to protest the Trump presidency, he had cut up his "green card," the document for his permanent residence in the United States (not that he appeared to have really lived there for some time, but that is perhaps not so unusual for green card holders). ${ }^{1}$

In his brief after-dinner speech at the 1986 festivities, Wole Soyinka noted that the Yoruba god Ogun, "the god of creativity and destruction, of the lyric and metallurgy," and his own creative muse, had anticipated Alfred Nobel, that inventor of dynamite, "by clearing a path through primordial chaos, dynamiting his way through the core of earth to open a route for his fellow deities who sought to be reunited with 
us mortals." He wondered aloud why Ogun had passed his secret to Nobel, rather than to his Yoruba descendants. Ogun might have drunk some of the local akvavit to take him through the harsh, dark Swedish winter, although he would certainly have preferred palm wine.

A couple of days earlier, Soyinka had given his longer and more serious Nobel lecture. This was a lecture by a Pan-African nationalist: it had a focused attack on what was still the apartheid regime in South Africa, but there was also a more general reminder of a past of domination, discrimination, and prejudice. Later, in his account of his Stockholm journey in You Must Set Forth at Dawn (Soyinka 2006: 323-334), he would devote little space to the official events, and more to a couple of bizarre local events behind the scenes, and to his travel. There had been half a jumbo jet of compatriots flying with him to Stockholm, and so "the Nigerian contingent was enlivening the staid streets with colors, textures, and exotic sounds." But he had wanted no official participation by the Nigerian government. These were the days of the military regime of General Ibrahim Babangida, relatively benign although nonetheless corrupt, and not entirely nonviolent either. Soyinka suspected strongly that it had been behind the recent murder by bombing of his friend the journalist Dele Giwa. ${ }^{2}$

In a long career, Wole Soyinka has been a strikingly versatile writer, a public figure, and an intellectual gadfly. Perhaps it is possible to suggest a periodization of his main contributions and activities, even with some imprecision, and back-and-forth movements. In rather early adulthood, in large part his student days in the United Kingdom, there was Soyinka the dramatist, writing plays and also active on stage and backstage himself. ${ }^{3}$ That continued in Ibadan, and with his part in the circle around Mbari Club (see chapter 6).Then in the late 1960s, in the period of major Nigerian upheaval, there was the political activist, at one point hijacking a radio station, but also spending time in prison under one early military regime. These were the times of his nonfiction narrative of imprisonment in The Man Died (1972) and the novel Season of Anomy (1973). Later, there would be Soyinka the memoirist, with the account of his childhood, Aké (1983), and a dramatic variety of adult activities in You Must Set Forth at Dawn, mentioned just before. In the essays in Of Africa (2012), he is again the Pan-African and global, cultural and political commentator. Yet such a summary of a path through life can still leave out a great deal.

In You Must Set Forth at Dawn, apropos his 1960s political engagements, he reflects that "I am always amused-or irritated, depending on my mood-by much that has been written about my so-called loner mentality" (Soyinka 2006: 82). "Loner" does not really 
seem such an appropriate description, if by that one would mean someone turning away from the world. There is, rather, in many of Wole Soyinka's activities a rebellious streak. The identification with Ogun, the Yoruba deity of war, hunting, and blacksmithing, guardian of the road, "creative-combative," seems quite revealing. ${ }^{4} \mathrm{He}$ is comfortable as an adversary, engaging in debate on many stages, local or wider. He has also taken extraordinary political action on his own. This, however, is not just a matter of temperament; it is a temperament responding to kinds of situations.

The radio station affair is a major example, recounted in detail in You Must Set Forth at Dawn (2006: $80 \mathrm{ff}$.). In what was then the Western Region, with Ibadan as its capital, a breakaway group from the older Yoruba-dominated party had formed its own party, which, with the support of the dominant Northern party, had somehow taken over the regional government. In 1965 there would be regional elections. The election campaign turned very violent-this was the campaign that Ryszard Kapuscinski (1990) reported on in a chapter of The Soccer War (see chapter 8 in this volume). At the end, that new governing faction claimed to have won, but the vote count was most likely fraudulent, and Wole Soyinka determined that it must not be allowed to be announced without challenge. He made his way into the broadcasting building, past what happened to be Amos Tutuola's cubicle and past the director's office, to the studio, where he could place his own message on the air: "Drop your stolen mandate, leave town, and take your reprobates with you."

Soyinka then escaped to the Eastern Region but was seized there, and eventually appeared in court on a charge of "armed robbery." The judge, sticking to the rule of law, threw that out. Yet it would not be so long before Soyinka would be in jail again, after he had made his very own attempt to avert the secession of what would become Biafra. (The head of the breakaway state had been his affluent acquaintance in the 1950s, when they were both spending youth years in Lagos.) $\mathrm{He}$ was hunted down, once more in Ibadan. More than two years later he would emerge from prison, in Kaduna. Soyinka offers his view of that period in The Man Died.

Soyinka's life and his location on the map of the world clearly again and again placed him in situations where the inclination to seize the day may have seemed rather natural. In Nigeria around 1960, there were the years of regime change, from colonial to postcolonial. Then there would be the disorders and rebellions of the later 1960s, and later yet the difficult years of military dictatorships. His country had areas of recurrent unrest: the Niger Delta again and again, parts of the 
North. Moreover, this was a country with a history of blurred borders, and where the forces of global interconnectedness made such blurring, as well as border transgressions, more common yet. Weak structures may leave room for, even seem to demand, individual agency.

In his Nobel after-dinner speech in Stockholm, Soyinka referred to the Yoruba god Ogun as his own muse. What has been his relationship to Nigerian, and specifically Yoruba, cultural tradition? In a roundabout way, that will be the question for the remainder of this chapter.

We can only see that reference to Ogun, in the Swedish winter and trying akvavit, as rather playful. In that Soyinka seems rather consistent. The Yoruba pantheon and Yoruba mythology is a significant resource for his creativity, but he does not allow himself to be confined by it. In an early, oft-quoted critical response to the Négritude concept of Francophone African intellectuals, he found it too defensive: "A tiger does not proclaim its Tigritude, it jumps on its prey." And later, when the prominent Nigerian literary critic Chinweizu argued that African writers should stick to their precolonial roots, treating all ideas, experiences, and practices dating from later periods as alien (perhaps in a way a surprising proposition, considering that Chinweizu had American academic degrees in his own cultural baggage), Soyinka (1993: 294) would respond that his own African world was "a little more intricate," embracing "precision machinery, oil rigs, hydroelectricity, my typewriter, railway trains (not 'iron snakes'!), machine guns, bronze sculpture, etc." And he concluded that Chinweizu's literary program amounted to "neo-Tarzanism."

Not so much later, in the digital era of the twenty-first century, that typewriter may already seem a bit quaint.

Yet despite his scorn for neo-Tarzanism, Soyinka's concern for the African, Nigerian, and Yoruba heritage has also had a more serious, deeply felt dimension. To get to this, let us meet another public intellectual, from another era and another country. Sometime in the early decades of the twentieth century, in Vienna, an expectant audience is seated in front of a darkened stage. Then a strobe light comes on. There is Leo Frobenius, dressed in a leopard skin, shouting: "Africa lives!"6

Frobenius, explorer, scholar, and indeed public intellectual, had a showmanship side as well. It seems he performed widely in Germanspeaking parts of Europe. (A description like this may remind us of the Buffalo Bill show of America's Wild West, touring in Europe a little earlier.) The son of a German lieutenant-colonel, he had developed an interest in Africa early, although it took some time before he had a 
chance to go there. It was at a time when much of the continent seemed more or less up for grabs from the outside. The German empire had been a little late in this, although it had established itself with colonies of somewhat different types in the East, South, and West. When Leo Frobenius began traveling widely around the continent, his motives seem to have been a mix of scholarly and political at least some of the time. At some point rather early in World War I, he was apparently deported from Eritrea due to his subversive activities; Eritrea was an Italian possession, and not on the side of Germany. Apparently he had hoped to recruit Abyssinia, further inland (not yet known as Ethiopia), as a German ally. Indeed, Frobenius has been portrayed as a German counterpart of Lawrence of Arabia. The last German emperor, Wilhelm II, became one of his fans (although perhaps especially after the throne was lost).

But Frobenius was a scholar too. ${ }^{7} \mathrm{He}$ wrote, but he also made careful drawings of people, scenes, and objects, which became important documentation of African cultures and societies as they were in his times. For one thing, Leo Frobenius was also at Ife, sacred site and major urban center of the Yoruba, and was very impressed with what he saw-particularly of the remains of the past, rather less with what it was under early twentieth-century colonialism. For a modest amount, he acquired an exquisite bronze sculpture of a head, described as the Ori Olokun, normally buried in the palace grounds between ritual occasions. Olokun was an ancestral goddess-or god, the gender seems a bit unclear-of the Yoruba (as the overall ethnic identity would come to be constituted), and also the goddess of the seas.

The resident, the high government officer in Ibadan, would not allow Frobenius to take the Ori Olokun out of British territory, so he confiscated it. From there on, the whereabouts of the ancient sculpture became a mystery. The object that later came to be exhibited in Ife itself was understood to be a mediocre copy. Frobenius, for his part, continued his journey westward. If Mariana, the heroine in Olinto's novel (see chapter 2) had been for real, she might have spotted him on his way along the coast, somewhere around Ouidah.

Then, on 30 January 1911, the New York Times had a report with the headline "German Discovers Atlantis in Africa." With Berlin as dateline, the news originated in Togo, a German colony at the time, stating that Leo Frobenius, who had reached there, could let the world know that he had found the site of the lost continent of Atlantis. While Ife is not explicitly mentioned, he based his assertion on his discovery of a bronze sculpture, evidently in that city. 
This would go with his Big Picture of ancient African history, speculative, as much thinking about the continent's past was at the time: cultures could make their appearance, move, and then vanish. As he did not find the Ife that he had seen really worthy of ancestors capable of such creativity, the Ori Olokun and similar masterpieces must be somehow leftovers from an earlier civilization.

Back in Germany, now a republic, Frobenius collaborated for a while with Oswald Spengler, author of the bestselling Der Untergang des Abendlandes. In Europe, this was a time of cultural pessimism. But Frobenius could be celebrated for his adventures and his views"Africa lives!"-and become an ancestral figure himself for a later German anthropology. ${ }^{8}$ He died in 1938.

In his Nobel lecture, Soyinka referred to Frobenius and to his unwillingness to accept that bronze sculptures such as the Ori Olokun could have been the work of people like the Yoruba he met at Ife. Soyinka was also sharply critical of the way that the riches of nonEuropean cultural heritages had been taken away from their origins to be exhibited in European museums. Later on, it is true, it has become a matter of international cultural policy to return at least some of those valuable or unique artifacts to their countries of origin. What Soyinka did not mention in his lecture, however, was that several years earlier, in a characteristic Soyinka activist style, he had engaged in a do-ityourself project along such lines. ${ }^{9}$

This takes us back once more to Salvador, the Brazilian city from which (in chapter 2) the family of Olinto's Mariana had once departed for Lagos. Some time apparently in the late 1970s, one of Soyinka's Yoruba friends had come back, shaken, from a visit there: in a private gallery he had been shown the real Ori Olokun! It was there on a shelf, in a small exhibition room at the back of a local architect's home, along with diverse objects from various parts of the world, or from the artistic owner's hands. The Yoruba visitor, however, could not fail to recognize this sculpture.

Here another remarkable transnational scholar-adventurer enters the story: Pierre Verger. ${ }^{10}$ Born early in the twentieth century, Verger was a child of a prosperous French family, and had taken a liking to photography. He moved about in the world, mostly within his country's empire as it was between the world wars. But then he happened to visit the Bal Nègre, a celebrated midcentury Paris nightspot, and saw a ballet performance that impressed him greatly: African Americans dancing. Off he went to the Caribbean and to Latin America, and ended up in Salvador, where he would then spend most of his life, dying at age 94. 
He was fascinated by the ubiquitous survivals of African religion, was initiated into a cult community, and became as much an ethnographer as a photographer.

Verger has been seen as an exemplar of the possibility, and perhaps sometimes intellectual risks, of "going native," assimilating into a host culture. Yet it may well be that he was never quite a true believer in his Afro-Brazilian cult community. He may rather have appreciated its world view and its rituals intellectually and aesthetically, in a way that went with his photographic artistry.

Starting out from Salvador, he also made excursions to West Africa, mapping in writing and with his camera the striking similarities between Afro-Brazilian and Yoruba religious life. Without much in the way of formal academic training, he learned about this from local cult practitioners, and became a babalawo, a diviner. Belatedly, his French mother country offered him a doctoral degree at Sorbonne, and he held sometime professorships in Salvador as well as Nigeria-at the university in Ife.

So now Pierre Verger had been among the other guests at that architect's home in Salvador, and when the Nigerian visitor saw the sculpture he thought he recognized, he asked Verger whether that was not Ori Olokun. And, very authoritatively, Verger confirmed that it was. When Soyinka's friend asked how the world-famous, lost sculpture had ended up there, Verger placed his finger over his mouth, and whispered that he had brought it himself.

Ori Olokun had to be brought back to Nigeria, to Yorubaland-that was the shared opinion of Wole Soyinka and a small group of friends and co-conspirators. They met with General Obasanjo, military head of state at the time and, like Soyinka, an Abeokuta native, although at the time based at headquarters, Dodan Barracks, Lagos. He seemed to favor their plans, while remaining (as so often, according to Soyinka) rather enigmatic.

Their conclusion was that Soyinka, together with the friend who had first discovered the sculpture in its Salvador hiding place, would go there again, and at some moment, preferably unobserved, kidnap the ancestral goddess. As it happened, Pierre Verger would be in Nigeria at the time, on scholarly business. Arrangements were made to delay his return to Brazil—he was one of very few people who might see through the plans of the Nigerians, and who could disrupt them.

Soyinka and his helper arrived in Salvador, and Soyinka was fascinated by finding himself in something like another Yorubaland, at shrines and in cuisine. As it was some kind of holiday, the townspeople 
seemed like lemmings to have left for the Atlantic beaches, and the architect-owner of the gallery was apparently among them. When he returned, however, he invited the Nigerian visitors for dinner, after showing them his collections. At some point, Soyinka managed to sneak back there and lift the Ori Olokun from the shelf into his camera bag.

On their way back to the hotel, he revealed what he had done to his surprised companion. Yet then almost immediately the triumph turned into puzzlement. That was not some heavy bronze sculpture he had seized. It was light, probably in clay. On their return journey to Africa they made a stopover in Senegal to have the object examined at a renowned research institute. It was confirmed that the appearance of the sculpture, and its measurements, were exactly those of the Ori Olokun (according to Frobenius's detailed field notes). What Soyinka also discovered at this examination, however, were two small, thin letters carved into the sculpture's neck: BM. British Museum. Apparently this was a well-done museum copy, perhaps sold at some time in the museum gift shop.

To make a long story short, Soyinka continued his quest. He was back in Nigeria for a while, and then went to London, to the storage rooms of the Museum of Mankind, the West End museum that had become the heir to the more exotic collections of the British Museum. Indeed, he was allowed to examine what was understood to be the real Ori Olokun. In a momentary fantasy, he thought of seizing the sculpture, escaping into the bustling street life outside, followed by white-coated museum staff. The "Stop the thief!" shouts would soon have the support of "the phlegmatic London bobbies on the beat blowing their whistles..."

But that was only a fantasy. Wole Soyinka's conclusion was that when his good Yoruba friend had first seen the Ori Olokun at the home of the Brazilian architect, Pierre Verger was a bit tipsy, in the party atmosphere, when he hinted that this was the original from Ife. If he had not done so, the story would have ended right there, hardly even becoming a story. As it was, Verger perhaps seemed less like a follower of Ogun, and more of Eshu, the Yoruba trickster figure.

After Soyinka recounted his adventure too, the authenticity of the sculpture in the Museum of Mankind was later certified, as far as is possible, by museum expertise. So the Ori Olokun is still in London. 


\section{Notes}

1. Yet later, I could get a sense of Wole Soyinka's continued opinionated view of the contemporary world in David Pilling's (2017) lunch interview with him for the Financial Times-portraying him as "the Bohemian man of letters who doesn't give a damn."

2. Dele Giwa was the editor of the Newswatch magazine, and had been investigating a case of drug dealing that possibly reached into high government circles. Soyinka's discussion of the events involved are in You Must Set Forth at Dawn (2006: 314-321).

3. Well-known plays like The Lion and the Jewel (1963) and A Dance of the Forests (1963) are from this period.

4. Part I of You Must Set Forth at Dawn is titled "Ogun and I."

5. For Chinweizu's overall critical stance see Chinweizu, Jemie, and Madubuike 1985. This author trio, for their part, in their preface launched a label for themselves as "bolekaja critics"- "outraged touts for the passenger lorries of African literature." Bolekaja is a Yoruba expression for "Come down, let's fight!" shouted by mammy-wagon conductors at dissatisfied passengers already seated and protesting crowded seating or delayed departure. As the notion earned a certain popularity, it is a noteworthy case of cultural transfer from lorry park to literary debate. See on this also Appiah 1992: 56-60; Kanneh 1998: 38-42; and an editorial by Anyaegbunam (1993) in Journal of Communication Inquiry.

6. I have the description of a Frobenius performance from my friend and colleague Thomas Fillitz, of Vienna; he had not witnessed it himself but had it from oral tradition. For an account of the Ori Olokun affair with an emphasis on the Frobenius phase, see Fillitz 2011.

7. Frobenius's publications were mostly in German; but see the translated The Childhood of Man, first published in 1909 and then again in 1960 (in paperback, by a reputable publisher), described on the front cover as "A popular account of the Lives, Customs and Thoughts of the Primitive Races." For a rather favorable account of his work and influence, including his later significance for the mid-twentieth century Presence Africaine circle of Francophone intellectuals, see Marchand 1997.

8. As German academic life reconstituted itself after World War II, Leo Frobenius was seen as a reasonably uncontroversial symbolic figure, so what he had started in Munich as the Research Institute for Cultural Morphology was now in Frankfurt am Main as the Frobenius Institute, which has remained a center of German anthropology.

9. Soyinka's account of this adventure is in You Must Set Forth at Dawn (2006: 190-221).

10. On Pierre Verger, see for example the obituary in the New York Times, 20 February 1996. For one thing, Verger (1960) had an article on the connections between Nigeria, Brazil, and Cuba in the very large, rich, special Independence issue of the government-sponsored journal Nigeria in 1960 (also including contributions by, among others, Cyprian Ekwensi, Onuora Nzekwu, and Ulli Beier). 


\section{References}

Anyaegbunam, Chike. 1993. "Bolekaja in the Construction of Africa in Intellectual Discourse." Journal of Communication Inquiry 17(2): iii-x.

Appiah, Kwame Anthony. 1992. In My Father's House. New York: Oxford University Press.

Chinweizu, Onwuchekwa Jemie, and Ihechukwu Madubuike. 1985. Toward the Decolonization of African Literature. London: Routledge \& Kegan Paul.

Fillitz, Thomas. 2011. "Vom Sammeln und Klassifizieren." Mitteilungen der Anthropologischen Gesellschaft in Wien 141: 209-217.

Frobenius, Leo. 1960. The Childhood of Man. New York: Meridian Books.

Kanneh, Kadiatu. 1998. African Identities. London: Routledge.

Marchand, Suzanne. 1997. "Leo Frobenius and the Revolt against the West." Journal of Contemporary History 32: 153-170.

Pilling, David. 2017. "Lunch with the FT: Wole Soyinka." Financial Times, 4-5 November.

Soyinka, Wole. 1963. The Lion and the Jewel. London and Ibadan: Oxford University Press. . 1963. A Dance of the Forests. London and Ibadan: Oxford University Press.

- 1972. The Man Died. London: Rex Collings. 1973. Season of Anomy. London: Rex Collings.

- 1983. Aké. New York: Random House.

- 2006. You Must Set Forth at Dawn. New York: Random House.

- 2012. Of Africa. New Haven, CT: Yale University Press.

Verger, Pierre. 1960. “Nigeria, Brazil and Cuba.” Nigeria (special Independence issue). Lagos: Federal Ministry of Information. 


\section{A Voice from the Purdah Baba of Karo}

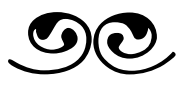

Anthropologists have been inclined to see themselves as the spokespeople of the people they study, especially when the latter for some reason are less able to make their own voices heard. Even if they do not fully accept "the native's point of view" personally, they should at least be able to explain it. Yet in fact, they are usually not the unadulterated voices of those locals. They tend to write in academese to reach their scholarly peers, and if at best there is clarity and precision in this writing, it is mostly not of any remarkable literary quality. Thus, it may be a somewhat costly form of cultural brokerage.

But there has been a twist to this due to gender inequality in academia. When academic couples have been doing field research together, it could be a moment within a career pattern where, moving into a post-field phase, the man is in the driver's seat. His wife could have a slightly less prominent career of her own, or she could become a faculty wife.

This is hardly the situation any longer, but it was in large part true in the late colonial period. And the intriguing part of this pattern was that it could give the woman in the team rather greater freedom to experiment and take liberties in writing, as she was less constrained by mainstream career planning anyway.

Late colonial anthropology in Nigeria offers two examples of this. One of the pioneer contributions to a literary anthropology was Elenore Smith Bowen's Return to Laughter (1954), a slightly fictionalized account of the personal experience of research with an unnamed tribal community. But everybody knew that "Elenore Smith Bowen" was the nom de plume of the Oxford-trained American Laura Bohannan, who had conducted her field work with her husband Paul among the Tiv in Central Nigeria; the Bohannans published extensively under their 
regular names in academic contexts. Return to Laughter is by now seldom mentioned in studies of Nigerian writing. A short article, "Shakespeare in the Bush," about Tiv elders' interpretation of, and critical response to, the Hamlet story has perhaps become yet more of a classic (Bohannan 1966).

But Return to Laughter revolved rather more around Laura Bohannan's own experience. Less known is Mary Smith's Baba of Karo, published in the same year (1954). Mary Smith, British, did not come to have an academic career of her own, but she was in Northern Nigeria with her husband M. G. Smith, a British-trained and British-based Jamaican of Colored elite background. M. G. Smith eventually became a professor at University College London. ("M" in M. G. Smith stands for Michael, but he has usually been referred to by his initials.) In Nigeria, he was primarily a political and historical anthropologist. For example, he wrote about political development in Kagoro, a chiefdom just next to Kafanchan, where with considerable success a progressive chief combined the power given to him under "indirect rule" with the organizational and ideological resources provided by missionary Christianity. ${ }^{1}$ Above all, however, Smith wrote two large monographs about Northern emirates: Zaria and Daura (M. G. Smith 1960, 1978). (Daura, the less-known of these two, happens to be the original home of General Muhammadu Buhari, New Year's Eve 1983 coup leader, and in 2015 and again 2019 elected president.)

These monographs were very much in the not-very-accessible style of the academic anthropology of the times. Mary Smith, on the other hand, concentrated some of her effort on assembling what amounts to an autobiography of Baba, an elderly Hausa woman. The full name "Mary Smith" actually appears nowhere inside the published book, only on the spine. On the title page, she is "M. F. Smith." In a brief preface by Professor Daryll Forde, director of the International Africa Institute (and her husband's superior and advisor), she is Mrs. Smith. In an extended introduction to the book, on Hausa ethnography and by her husband, she is "my wife." This, of course, communicates more about the midcentury academic order and style than about the Hausa. The book ends with thirty-some pages of explanatory notes by M. G.

Baba of Karo appeared two years after Amos Tutuola's The PalmWine Drinkard, and with the same London publisher, Faber and Faber. And Professor Forde had had a hand in that publication as well. ${ }^{2}$ The Africanist circle in London was not so large.

M. G. Smith's introduction informs us that Mary Smith interviewed Baba on a daily basis for an average of three hours per day over a sixweek period. That would come to well over a hundred hours. Apart 
from that, she also collected a dozen case histories from other local women. It is made clear that only a woman could have gathered this material - a man would not have had access, as the Hausa women were secluded in purdah. ${ }^{3}$ A large part of the work took place in Zaria, as the Smiths invited Baba to come along from the village to their headquarters in the larger city, where the interviewing could be carried out more efficiently. Older village women, said Baba, had not thought this was a good idea: "Don't go to the Rest House, the Europeans will pick you up and take you home with them in an aeroplane. Don't go!" (Mary Smith 1954: 12)

A few generations earlier, Baba's ancestors had actually been Kanuri people, moving in from the northeastern land of Borno, but by now Baba definitely considered herself Hausa-with a dominant language and with an expansive form of Islam, the Hausa identity had great assimilative power. Ethnic boundaries seem to have been a bit blurred, and could be crossed.

Baba of Karo is a first-person narrative. ${ }^{4}$ One could imagine Mary Smith as Baba's ghostwriter-appearing nowhere in the book herself, in her own voice, with an authorial or editorial "I." That also means that whatever there may have been of Baba's personal response to the young white woman in front of her is not noticeable in the text. Nor is there much in the way of reflective, inward-looking commentary, either by Baba or by Mary Smith, as "Elenore Smith Bowen" could have in Return to Laughter.

The account of everyday activities, however, is often lively enough. As a young girl (presumably in her early teens), Baba would go with other girls to outlying village markets to buy garden produce cheaply, then take it home to cook so it could be taken next morning to be sold as ready-made food in the more central market. There was a nice modest profit (in cowrie shells) to be made from this. But then, as some or even all of that profit could go into donations to young male drummers and praise singers accompanying them, the girls might still have to ask for new investment capital from their mothers before their next excursions to those villages.

Baba's mother was from a family of drummers and blacksmiths, but she died when Baba was about ten years old. At the beginning of the rainy season, there is a period of intense thunder and lightning, and Baba's mother and her two younger children were in her hut when lightning struck. Baba's father cried, although he was surprised to find that Baba and her brother had survived: they had been away from the hut at the time. Then a beautiful, young female slave came to live with them so that Baba's father would not have to be like a bachelor. 
She became pregnant soon enough, but as she went away to visit her maternal kinsfolk some distance away, she died too.

So a father's sister became like a mother for Baba, but then this aunt was somehow abducted to distant Abuja. ${ }^{5}$ When Baba was around fourteen, it was time for her to get married. A suitable husband was found, a farmer and second cousin. Evidently Baba agreed, but without real enthusiasm, and hinted to another suitor of a blacksmith family that it would be his turn next. She reminisced about the intricate and extended wedding arrangements, after which she went off to live in her husband's village. But then the aunt was retrieved from Abuja, and, as circumstances of life changed, Baba could decide that she did not enjoy life in the village-she preferred the nearby town where that young man of a blacksmith family lived, still available. (Actually, he was by now a malam, a Koranic teacher.) The divorce from the first husband, after a few years of marriage, was amicable. The second marriage lasted longer, some fifteen years. In both those marriages, Baba was a junior wife, however, and the senior wives already had children, while Baba remained childless. That had at least one advantage: when her husband traveled for teaching and preaching, she could go along. Yet when the malam acquired a third wife, who soon enough had children, Baba's position became untenable. The aunt who had become like a mother did not care for the malam either. So Baba divorced once more, although remaining on friendly terms with this set of in-laws.

Then, by way of a set of kinship links, she became acquainted with another man in another village: a farmer and prison guard. He already had four wives, the maximum number allowed, but as he desired Baba, he divorced one of these. Indeed, after some time, Baba had him to herself. On the other hand, later on, when a village chief died and his wife, Baba's good friend, was pregnant, Baba arranged for her husband to marry this friend. Then, however, the husband had a sister who was widely seen as troubled and quarrelsome, so this was something that Baba had to deal with for an extended period.

This third husband died, and Baba became a widow. Apparently it was not a good idea for an elderly woman to be alone, so she married a fourth time, to a farmer. But they did not live together. This new husband already had a wife, who had gone away to see kinspeople, and Baba worried that if she turned up again, they would not get along. So Baba stayed in the compound of a younger brother. The husband came around one morning, after he had heard that Baba was working with a European woman - that is, Mary Smith—to point out that this was an infringement on his domestic authority. Baba gave him sixpence to go 
the market and get some kola nuts and meat and things for stew, and so he walked away again very pleased.

There are parts of Baba's story offering intricate descriptions of domesticity, bond friendships, and related ritual rules and cases of infringement that a reader without any specific deep interest in Hausa culture may find rather hard going. Nevertheless, some topics may draw special curiosity. Slavery is one of them: it is described as involving sets of close, quasi-domestic, often largely benign relationships. When a male slave wants to marry someone else's female slave, his owner becomes engaged in the marriage negotiations and pays the bride price for the desired woman to her owner-even as she remains the latter's slave. On the other hand, when an owner frees a slave, he may proceed to adopt him as a son.

There are more such practices creating a multifaceted web of varyingly close linkages.

Then, of course, the Europeans came, in the early years of the twentieth century. Baba would have been around twenty-five at the time, and in her second marriage. Talking to Mary Smith, she was inclined to refer to the newcomers not as "conquerors" or "British" or "Europeans" or "whites," but often as "Christians," seemingly the most significant categorization. The arrival of a Pax Britannica was apparently not entirely unwelcome either, even if some places like Kano had to be taken by force. There had been a period of violent conflicts in the area just before, so it was okay to get some peace.

The Europeans, perhaps with an understanding of slavery based less on local knowledge and more on what had been its recent cruel forms in Plantation America, quickly banned what they found of it in their new Hausaland territories. But even as it may have been formally abolished, it would not seem that-as an informal, personal, and collective clientage type of relationships-slavery disappeared quite so quickly. (By the time I came to Kafanchan in the 1970s, the neighborhoods of the descendants of the people once enslaved by the emir of Jemaa could still be identified.)

Again and again, Baba would also come back to the topic of the Bori cult. This possession cult shared some traits with cult life among the Maguzawa, those "heathen" Hausa who had not adopted Islam. It offered a certain refuge for women who somehow, temporarily or more durably, did not fit into conventional married life. They supported themselves at least in part through prostitution. Some males who might have been of homosexual inclination would hang out with the cult as well. But it was under female leadership, and the malams, Koran 
experts, seemed anxious to be on good terms with that leadership. One might sense some coexistence of religious traditions here.

Bori dancing was also a popular public spectacle. Baba reminisced about a time when there had been a Bori cult compound in the vicinity, and about an occasion when one woman, possessed by the Boxer spirit, performed her song and dance; when the spectators gave her money, she had in turn given it to Baba. She remembered well, too, how one of her co-wives with the third husband, the prison guard, was a Bori follower. After this woman got into a quarrel with other cultists, their husband told her off, and so she picked up and left. A half century after Baba of Karo, a more elaborated gender studies perspective would find the Bori cult intriguing material. ${ }^{6}$

There is, in Baba's midcentury account and commentary, little sense of some sort of modernity as an alternative mode of living. The bright lights of the city do not seem to be on the horizon-even as those women in her village neighborhood are evidently aware of the international airport in Kano (which had recently been in quite intense use in World War II). Instead, in Baba's view, life has simply been as it has: no need to be defensive about it, or compare it to anything else.

The book has a brief postscript. Mallam Abdu, local Arabic teacher, has written to Mary Smith in London to inform her that Baba died on 3 June 1951, aged 74. He had given one pound two shillings so a shroud could be bought for her.

By then, further south in Hausaland, a boy named Ibrahim Tahir was just moving into his early teens.

\section{Notes}

1. I have had the pleasure of extensive conversations with both the Smiths, in London, and the chief of Kagoro, Gwamna Awan, in his mansion.

2. I refer to this in chapter 1, note 1. There was another edition of Baba of Karo published by Yale University Press in 1981 (while M. G. Smith was a professor at Yale University); this edition is still available.

3. There are later anthropological studies of Hausa womanhood in a volume edited by Coles and Mack (1991).

4. There is a certain broad parallel to Baba of Karo in the book Akiga's Story: The Tiv Tribe as Seen by One of Its Members (East 1939). But the story of the latter is more complicated. Akiga Sai (1898-1959) was a mission school product, consequently literate, and wrote his text himself, a rather diverse account of history, ethnography, autobiography, and more, intended primarily for younger Tiv readers. But the better-known published version was edited by Rupert East, who as a member of the Northern Nigerian 
colonial government took a wide-ranging interest in literacy, writing, and publishing. Another edition of Akiga's Story was published in 1965, presumably as part of the postcolonial reawakened interest in locally produced texts. On this see Fardon 2015.

5. This was old Abuja, not the present national capital. Old Abuja is now Suleija, nearby.

6. There are updates on the Bori cult in a Festschrift for Daryll Forde (Onwuejeogwu 1969), in Masquelier's (1993, 2001) study of the Bori in a town in the Niger Republic, and in a chapter in the book referred to in note 3. Matthias Krings (2015), German anthropologist with field experience from Kano from the 1990s onwards, offers varied comments on the Bori and related cults and movements in the context of Northern Nigerian and African popular culture. In Kafanchan in the mid-1970s, a compound in the Hausa neighborhood was known to be the local site of Bori activities.

\section{References}

Bohannan, Laura. 1966. "Shakespeare in the Bush." Natural History 75(7): 28-33.

Coles, Catherine, and Beverly Mack (eds.). 1991. Hausa Women in the Twentieth Century. Madison: University of Wisconsin Press.

East, Rupert (ed.). 1939. Akiga's Story. London: Oxford University Press.

Fardon, Richard. 2015. "Do You Hear Me? It is Me, Akiga': Akiga's Story and Akiga Sai's History." Africa 85: 572-598.

Krings, Matthias. 2015. African Appropriations. Bloomington: Indiana University Press.

Masquelier, Adeline. 1993. "Narratives of Power, Images of Wealth: The Ritual Economy of Bori in the Market." In Jean Comaroff and John Comaroff (eds.), Modernity and Its Malcontents. Chicago: University of Chicago Press.

- 2001. Prayer Has Spoiled Everything. Durham, NC: Duke University Press.

Onwuejeogwu, Michael. 1969. "The Cult of the Bori Spirits among the Hausa." In Mary Douglas and Phyllis M. Kaberry (eds.), Man in Africa. London: Tavistock.

Smith, M. G. 1960a. "Kagoro Political Development." Human Organization 19(3): 137-149.

- 1960b. Government in Zazzau, 1800-1950. London: Oxford University Press.

- 1978. The Affairs of Daura. Berkeley: University of California Press.

Smith, Mary. 1954. Baba of Karo. London: Faber and Faber.

Smith Bowen, Elenore (Laura Bohannan). 1954. Return to Laughter. New York: Harper. 


\section{Bauchi \\ The Academic and the Imam}

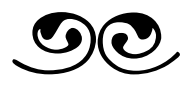

In chapter 6, we traveled through Ibadan, Enugu, Onitsha, and Nsukka, with some minor additional stops, all in southern Nigeria. In the north, Zaria may for some time have been the closest counterpart of these settings. The city of Zaria is the capital of a major old Hausa emirate, and not very far north of Kaduna, the more recent regional metropolis. We saw in chapter 12 that the Smiths took Baba of Karo there for extensive interview sessions. Ahmadu Bello University (ABU), with its main campus on the northern outskirts of the city, was the first university in the region, founded in 1962 and named (already in his lifetime) after Ahmadu Bello, the Sardauna of Sokoto, premier of Northern Nigeria, leader of the Northern People's Congress, and, until his murder in the first 1966 military coup, the most powerful politician in the country.

The writer whose only novel is the main topic of this chapter, Ibrahim Tahir, had strong links to ABU. ${ }^{1}$ His childhood home, however, was in Bauchi, a somewhat more southerly old emirate, where his education began at a Native Authority school (that is, not one run by any Christian mission). He went on to Cambridge University and took a doctorate in social anthropology, a department that for a long time was a stronghold of West African research. Then he returned to Nigeria, first taking up a teaching position in sociology at ABU; however, it does not seem that he continued to engage much in scholarly production.

The intellectual climate at ABU in the 1970s was one of a rather heated debate between right and left-the left represented most prominently by the historian Yusufu Bala Usman, and the right by Ibrahim Tahir. (Expatriate faculty in the human sciences seem in large part to have sympathized with the left.) In this case, Tahir was the been-to. Bala Usman, for his part, had a Northern aristocratic 
background-his father belonged to the Katsina Emirate elite, and his mother was the daughter of an Emir of Kano. ${ }^{2}$ But he had his doctorate from $\mathrm{ABU}$, with a thesis on the establishment of Katsina Emirate. His mentor had been a prominent, influential historian with the intriguing name Abdullahi Smith, originally Henry Fredrick Charles Smith, from Somerset, England. After serving in the British army in India during World War II, he went to Cambridge, and then went first to the University of Ibadan before he moved to Zaria. After many years in Nigeria, he converted to Islam and changed his name. Considering his intellectual impact in both Zaria and Kaduna, one may be tempted to see Abdullahi Smith as a Northern counterpart of Ulli Beier in Ibadan, to a degree "going native" while helping to shape an intellectual milieu.

Ibrahim Tahir, for his part, moved up in the university administrative hierarchy, played a somewhat complicated insider role in regional party politics after military government ended the first time around, and reputedly wrote unsigned editorial pieces for the New Nigerian. And then somewhere he found time to write a novel, The Last Imam (1984).

Its theme is the tragic life of Usman, lead preacher-savant at the central mosque of Bauchi, closely linked to the emir's court. The young Usman more or less inherits the position from his father, who had it after his father; they are all of the proper Fulani ethnic background. Already at a very young age, the boy Usman shows his talent for scholarship, and he just goes on studying. In his teens, it is hinted to him that it is time to get married, but Usman continues celibate for several more years. When the young Aisha is more or less forced on him through a ritual arrangement, their first sexual encounter is violent, and widely gossiped about in town circles.

Yet Aisha soon becomes his strongest support in life, even as soon enough he acquires a second wife, and a third, and a fourth. She is also a source of household strength as Usman continues his career of learning and preaching. He accompanies his father on a pilgrimage to Mecca-but while there, the father dies. Dying in the Holy City, of course, is itself a matter of highest sacral status. When the son returns, however, now an alhaji, someone who has performed the hajj, it is selfevident that he must be Bauchi's new imam. People come to admire him and also fear him, as he shows his learning but also disciplines them, preventing them from backsliding into old but still tempting heathen practices. Among the slightly more secular office holders at the Emir's court, it is true, there is some resentment. Yet Usman sees his main adversary as Sheitan (Satan).

A success story so far-but there comes a new complication. To begin with, it adds to Usman's happiness. There is a beautiful teenage 
girl, Hasana, daughter of a former slave family. (The British have certainly freed the enslaved, but it does not really matter so much.) As he already has four wives, Usman can only take her as a concubine, but as such she becomes his favorite, and, when soon enough she bears a child, this son, Kasim, also becomes a cynosure.

Then things fall apart. After more than a decade of shared happiness with Usman, Hasana falls ill and dies. As he grows up, Kasim turns out to be bright but unruly, and disliked in the wider polygamous household. Consequently, the relationship between father and son is increasingly tense.

At one point, Kasim runs away, but is returned to his father by an itinerant mallam, Shuaibu, who has found him. Usman is now faced by a rebellion in the household, led by Aisha. He returns home early in the morning from the emir's court, where he has spent most of the night in a group waiting for a sighting of a new moon, to begin the month of Ramadan. But this means that he has neglected his nocturnal duties in bed with Aisha, whose turn it is, in the series of wives. While the other wives have borne children, Aisha has had only miscarriages, although still maintaining the authority of senior wife. Now they all threaten to run away. After a crisis, Usman asks for their forgiveness. But then Kasim decides to leave, to join Shuaibu and his flock of almajiri, homeless beggar students, continuing his education with them. Much to the consternation of townspeople, the imam's son is thus in the streets, doing demeaning odd jobs.

Usman's public performance as imam becomes unstable. He dresses idiosyncratically, putting on too much ceremonial clothing at the time when the season has become very hot. He rides a horse when it would make more sense to walk, and has conspicuous trouble mastering that particularly unruly, strong horse. The emir's courtiers seem to exchange questioning glances as they observe him. Still, he somehow pulls through.

The time comes when he and Shuaibu have an exchange only between themselves about their relationships to Kasim. Shuaibu reveals that he and Usman are in fact brothers-more precisely, half-brothers. When Usman's father, later to become imam, was in his teens, he had been as reluctant to engage in sexual life as Usman once was. At a time when he was visiting in Gombe, another large town, further to the east, a slave had taken him to a young slave girl to experience intercourse. ${ }^{3}$ Then Usman's father had returned to Bauchi and probably never knew that the slave girl had borne a child: Shuaibu. So that also meant that now Shuaibu was Kasim's paternal uncle, much like another father. Acknowledging that as a scholar he has nothing like Usman's learning, 
Shuaibu is deferential to what has turned out to be his younger brother. Nonetheless, he remains firm in his insistence that he should take charge of Kasim.

He does, taking the youth away to Gombe. But the relationship between Kasim and Shuaibu also goes bad, as Shuaibu treats his nephew harshly. Kasim wants to return to his father.

A period comes when the quality of life in Bauchi slides downward. There is a terrible draught. Herdsmen have to take their cattle further south, toward Lokoja, to find grazing. There is little garden produce for the market. Traders are having a hard time. People begin to grumble about what the imam is really doing-he is supposed to be their main intermediary with Allah. Their complaints find some support among the emir's courtiers.

Finally the rains come, and things are good again. But later come thunder, lightning, and a loss of lives. Then more drought. One day Usman is summoned to the court. At the end of lengthy proceedings, with much give and take, he finds himself unturbanned by the emir, removed from his office as imam. He will have no replacement; Usman will have been the last imam. If there will ever emerge one again, it will be someone more like Shuaibu. It turns out, moreover, that the emir has known all along that Shuaibu is the son of Usman's father. Word had already reached this emir's father and predecessor long ago, from Gombe.

What reflections may we have over The Last Imam? One could note, first of all, that before Tahir's novel, there had been little if any Northern Nigerian fiction writing in English-perhaps the nearest thing was Cyprian Ekwensi's handful of northern excursions. It may come naturally to compare it to southern writing of more or less the same period. There is no lack of drama and sensuousness in The Last Imam; yet these are not set within the freewheeling individualism of twentieth- or twenty-first-century Lagos. They occur instead within the domesticity of compounds, between kin groups, and up and down in an established local social-political-religious hierarchy. In this the story is not so unlike the episodical narrative of Baba's life, as retold in the preceding chapter.

There is also a notable timelessness. Pilgrimages to Mecca are mentioned, but it is not clear whether they take place overland or by air. Again, the English have freed the enslaved, but that was apparently rather long ago, and in some ways it does not make so much difference. In Usman's Bauchi there are no real strangers-no white people, no southerners. The one sign of new times may be that when the group at the palace are waiting to learn of a sighting of a new moon to begin 
Ramadan, the message may come by way of a wire from Kano, Sokoto, or Katsina. At least it seems we are somewhere in the twentieth century.

Tahir allows us to encounter the almajiri, pupils of peripatetic teachers of rather uncertain Koranic learning, in this case Shuaibu. The almajiri are still there-in the twentieth/twenty-first century they are understood as a social problem in urban Northern Nigeria. A recent novel, Elnathan John's Born on a Tuesday (2015), offers a first-person narrative of one of them, set in the context of political and sectarian tumult (but where we can note in passing that some of these youngsters now seem quite knowledgeable about British football teams). ${ }^{4}$ Yan iska, "sons of the wind," may have been a largely overlapping, more secular term. Boys or young men who have lost a secure foothold in their households of origin, they survive by doing odd jobs, begging, perhaps petty crime, getting a nighttime roof over their heads at least for a while from one of those freelancing mallams who teach them while very likely also keeping a good part of their street profits.

The almajiri, however, are not just a diffuse problem of city streets. People more or less like them and their teachers have again and again been at the roots of unrest in Northern Nigerian society. We may indeed be reminded already of Usuman dan Fodio, a rebel out of a scholarly Fulani margin of a northerly Hausa kingdom, coming from preaching a cleaned-up, Sufi version of Islam and moving on to the major jihadi rising in the early nineteenth century, still a central fact of Nigerian history. By the time when the British arrived a hundred years later, that uprising had transformed itself into a region-wide hierarchy, with the Sokoto caliphate/sultanate at its apex. Through the colonialist principle of indirect rule, it could then be further strengthened as a conservative establishment. (The Bauchi emirate, of course, was a part of this.)

In more recent times, there was the Maitatsine upheaval, climaxing with a massacre in Kano in 1980. Mohammed Marwa, more widely known as Maitatsine, "the one who damns," saw himself as a prophet, and a new Usuman dan Fodio; he condemned watches, radios, bicycles, and cars. After he and his motley gang of followers attacked and killed a large number of policemen, the authorities counterattacked. All in all, some five thousand people were killed (the number is very uncertain), including Maitatsine himself. ${ }^{5}$ Yet, on a smaller scale, the rebellion lived on.

Then in the early twenty-first century there has been Boko Haram, "Ban Western Education," centered in Borno in the northeast, led first by Mohammed Yusuf, then more dramatically by Abubakar Shekau, and in a more globalized era vaguely and mostly symbolically affiliated 
with the Islamic State movement of the Middle East (see also chapter 8). In its heyday, apart from kidnapping the Chibok girls (not least to satisfy the sexual urges of its young soldiers) and robbing banks, it also killed the emir of Gwoza, a Borno emirate.

Last but not least, The Last Imam offers us a glimpse of the importance of pilgrimage to Mecca. Usman and his father go there, although only Usman returns. It is said to have been a life-long regret of Usuman dan Fodio that he never made it to the Holy City. Now the hajj remains important in Muslim West Africa. In the past, it was an overland journey, and one should be aware that Nigeria's northern borders are hardly any more historically given than those along the Guinea Coast. Rather than using the name of present-day countries, or parts of them-such as "Northern Nigeria"-one should perhaps use a more neutral geographical term, such as Sahel, for the broad savanna belt stretching through much of the continent south of the Sahara desert. There are traces of past pilgrimages along the way, in Chad and in Sudan. ${ }^{6}$ Some, such as Usman, made it all the way. Others did not, remaining somewhere with their descendants as permanent pilgrims, so to speak.

Again, Ibrahim Tahir himself, returning to Nigeria with a Cambridge $\mathrm{PhD}$ and setting himself up in Zaria university life, was in a way a variation of the main Western-oriented Afropolitanism. His novel, on the other hand, bears witness to another transnational cultural continuum, with another center-periphery structure. In his brief, accessible account of Usuman dan Fodio's life and its impact on Northern Nigerian history, The Sword of Truth, the historian Mervyn Hiskett (1973: 36) emphasizes that Islam, for all of its long presence in Hausaland, has remained in a way alien to the West African milieu, with its transcendent Koranic authority resting in the end on literacy in Arabic. ${ }^{7}$ The monotheism of Islam, "with its teaching that death is a final severance from the world, and a prelude to divine reward or punishment in the Hereafter, is very different from the indigenous African beliefs which involve veneration for ancestors and a cyclical view of life and death." The Mecca here is not London or New York: it is Mecca. And at the peripheral end of that continuum, one perhaps finds those phenomena more rooted in local traditions, such as the Bori cult referred to in the preceding chapter.

Back to Kafanchan for a moment: by the 1970s, I would find that the wealthy Hausa contractor-entrepreneurs there would normally make their way to Mecca by way of Kano airport, and return as alhajis on the seasonal charter flights. Even if they came back with a lot of luggage, goods purchased at the upmarket shopping facilities around Mecca, 
they had above all converted financial capital into symbolic capital. The alhajis were another sort of been-tos.

As far as the hajj in its modern form was concerned, it could also have its regional and local political implications. Mecca, of course, was under Saudi control, and that host power used varied organizational means to broadcast its Wahhabi variety of Islam wherever it could reach. By the late 1970s, again, this had inspired a separate mosque in Kafanchan, competing with the town's old central mosque. The new mosque had loudspeakers in the street outside, and at least once it caused a street brawl. This was at about the same time as the Maitatsine movement was causing havoc in Kano, some six hundred kilometers to the north.

Christian entrepreneurs in Kafanchan, mostly those with their roots in local mission churches, found a counterpart to the hajj in a trickle of pilgrims to their own holy city of Jerusalem. And the blurredness of borders in the Sahel region was also hinted at in Kafanchan by the presence of a handful of Folomi-an ethnic identity perhaps locally invented at some time for migrants from around Fort Lamy, now renamed Ndjamena, capital of Chad.

Ibrahim Tahir died in Cairo in 2009, due to complications from diabetes. In a memorial note, one Northern Nigerian admirer claims to know for a fact that on the basis of The Last Imam, Tahir had been very close to being awarded a Nobel Prize in literature. Whatever may be the literary merits of the book, that seems absolutely unlikely. ${ }^{8}$ But perhaps since Wole Soyinka, a Yoruba, Southerner, and recurrent adversary of Northern dominance, had been awarded such a prize in 1986, it may just have seemed to some that it was the North's turn.

\section{Notes}

1. I was a research associate in the sociology department at ABU while conducting my field research in Kafanchan, but spent little time on the campus. To the best of my knowledge, I did not meet Ibrahim Tahir. The department still had expatriate heads at the time, and several expatriate faculty members.

2. For a view of Yusufu Bala Usman's collected opinions, see his For the Liberation of Nigeria (1979). Nineteen years after the country's achievement of independence, he apparently felt that this was still an adequate title.

3. We briefly encountered Gombe before, in chapter 8; Helon Habila, author of The Chibok Girls, grew up there.

4. Intriguingly, Baba of Karo - see chapter 12-also shows up here, among a young man's readings. Elnathan John, born in Kaduna in 1982, Christian, 
of mixed ethnic parentage, is himself a graduate of Ahmadu Bello University. He has a more recent short book of satire, Becoming Nigerian: A Guide (2019), published by Cassava Republic. Chapters include "How To Be a Pastor," "How to Be a Nigerian Writer," "How To Be a First Lady," "Tips For the Foreign Journalist Covering Nigerian Elections," and "Travel Advice for Nigerians Going to the U.S."

5. Paul Lubeck (1985), American sociologist and Nigeria specialist, discusses the Maitatsine rebellion as an outcome of the growing socioeconomic cleavage in Northern Nigerian society brought by the late 1970s oil boom.

6. For academic studies of the paths of West African pilgrimage in Chad and Sudan, see Works 1976 and Yamba 1995.

7. Mervyn Hiskett, notes the back cover of his book, was vice-principal of the School for Arabic Studies in Kano for a decade ending in 1962, and thereafter lecturer in Hausa Studies at the School of Oriental and African Studies (SOAS) in London.

8. Unlike, for example, Booker Prizes, Nobel Prizes are not awarded for a single book, but rather to writers with a larger body of authorship-more like a life-time achievement award. So The Last Imam alone could hardly have taken Tahir anywhere close to the prize.

\section{References}

Bala Usman, Yusufu. 1979. For the Liberation of Nigeria. London: New Beacon Books.

Hiskett, Mervyn. 1973. The Sword of Truth. New York: Oxford University Press. John, Elnathan. 2015. Born on a Tuesday. New York: Black Cat/Grove Atlantic. _. 2019. Becoming Nigerian: A Guide. Abuja: Cassava Republic.

Lubeck, Paul M. 1985. "Islamic Protest under Semi-industrial Capitalism: Yan Tatsine Explained." Africa 55(4): 369-389.

Tahir, Ibrahim. 1984. The Last Imam. London: Routledge \& Kegan Paul.

Works, John A., Jr. 1976. Pilgrims in a Strange Land: Hausa Communities in Chad. New York: Columbia University Press.

Yamba, C. Bawa. 1995. Permanent Pilgrims. Edinburgh: Edinburgh University Press. 


\section{Railtown Writers}

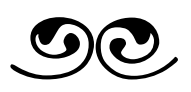

My first encounter with Kafanchan was rather accidental. On an early journey through Nigeria, at the beginning of the 1960s, the train I was on remained long at one station (as it did at many others), and the station sign said "Kafanchan." There were lots of people on the platform: travelers with all kinds of packages, people who were meeting them or taking leave, peddlers of all kinds. And then on the field next to the station there was also a lot of commotion, which did not seem to have anything to do with our particular train. People were on their way somewhere, on foot. The place seemed quite large, and yet I could not see an automobile anywhere. In the middle of the savanna, the town seemed to be linked to the rest of the world by rail only. At a distance, in the beginning dusk, a cliff rose above the greyish-green landscape. The train finally started moving again in that direction. The name of the town stuck in my mind, however, as it made my thoughts wander toward a quite different part of the world-Kafanchan . . .Teheran, Isfahan ...

The next time I ran into Kafanchan was soon afterward, in a novel by Onuora Nzekwu, of that first generation of Nigerian fiction writers. Blade among the Boys, from 1962, is the story of a young man, from his Kafanchan childhood on a crooked path through life, taking him through various Nigerian settings. But the continuous theme, as in much African prose of the period, is the tension between the obligations of local tradition and the individual ambitions of modern life. Patrick Ikenga wants to become a priest in the Roman Catholic Church—his parents have had him schooled by its mission. Yet when he becomes fatherless, the elders of the family's distant home village demand that he takes up an office connected to the old pre-Christian religion, and a girl in the village has been identified as his future wife since almost as soon as she was born. 
Again, Patrick Ikenga of the novel does not remain in Kafanchan for very long. He is an Igbo, so his roots are elsewhere. Moreover, as the Ikengas are a railway family, he finds himself at various times in different temporary homes along the rail. But before we get that far in the story, Onuora Nzekwu briefly portrays Kafanchan as it was in its earlier decades. He was born there himself, and one senses that he was a railway child. Local life revolves around the activities and the rhythm of the railway. ${ }^{1}$ Such power holders as the British colonial officers are hardly visible, except when Empire Day is celebrated. But there is a multitude of ethnic groups. Their various Christian congregations are in competition, while there is more distance between them and the Muslim Hausa, and for that matter the indigenous peoples of the area. These have not yet been so fully reached by the missions, and they come into town only very occasionally. Nzekwu allows Patrick Ikenga to notice that they hardly wear any clothing, and that the women often have only twigs of leaves between their legs.

Later on, when I was planning to do urban ethnography somewhere in Nigeria, I remembered the Kafanchan railway station and Nzekwu's book. On my reconnaissance trip to find a suitable field site, I thought I would have a look at Kafanchan first. Quickly enough, I decided that it suited me well, and I liked it.

By then, of course, Onuora Nzekwu was long gone-although he was nationally quite visible. To begin with, briefly, he was a peripatetic schoolteacher, but then he turned to writing. Wand of Noble Wood (1961) had actually been his first novel; after Blade among the Boys came Highlife for Lizards (1965). The first and the third are largely set in Igboland and offer a great deal of dramatized knowledge of Igbo culture, not least relations of gender, family, and kinship. But his bestknown book remained Eze Goes to School (1966), a slim volume for primary school use, an early reading experience for masses of Nigerian school children. ${ }^{2}$ Apart from that, he had started working early for Nigeria magazine, a high-quality quarterly government publication devoted to documenting Nigerian cultures. Soon enough he was its editor. The Biafra period, during which he had returned to the Igbo homeland, turned out to be a rather parenthetical interlude. He came back to Lagos, and for much of his remaining active years he was the general manager of the News Agency of Nigeria. His death, in Onitsha in April 2017, at age eighty-nine, drew nationwide attention. President Buhari, tweeting a condolence message, referred especially to the national importance of Eze Goes to School. Just a little later, one could find one copy of that book advertised at the Amazon.com website, at the price of US $\$ 706$. 
Another novel, accidentally encountered: as I am at Copenhagen Airport, waiting for the departure of my plane, I browse in a book stall. High on a shelf I come across Burma Boy (2007), by Biyi Bandele, about the young men who were recruited from West Africa's villages and small towns, many of them mere teenagers, to fight for the British Empire against the Japanese enemy on a different continent in World War II.

Their view of the world was hazy, their understandings of weaponry, terrain, and command were faulty and grew only through costly experience, and some of them would never come home again. But they were held together through all the hardships of the jungle war by their innocent faith in King George, their Nigerian background, and their Hausa and Pidgin dialects, which they used to share memories of life at home and to interpret what was new and alien. This was the Royal West African Frontier Force, once set up by the colonial master Governor Lugard.

Bandele's father had been a Burma veteran himself, and the novel had originally been inspired by the stories Bandele had heard at home as a boy. But then he had proceeded to read historical accounts and the biographies of British officers, and do research in the archives, and he had written his book with those materials as a background as well.

And then I found that the author of Burma Boy was from Kafanchan. He was born there in 1967, at a time when the town was in upheaval, with the large Igbo population fleeing after Northern pogroms, and at the beginning of the Biafra War. Even if he could hardly remember that, he would probably have learned about some of the consequences in his early years. And he could have been among the boys I encountered on the town streets by the time I arrived; if I did not notice him, it was still likely he would see me, the conspicuous stranger (and perhaps he shouted "oyinbo!"- “whiteman!" in Yoruba-as he spotted me). But for Bandele as for Nzekwu, Kafanchan was hardly a place to remain for an ambitious youth. The varieties of missionary Christianity dominating schools in the area were not particularly intellectually inclined. So he went south to study in Ife at Obafemi Awolowo University, renamed after the pioneer Yoruba politician. ${ }^{3}$ And from there he soon enough proceeded to London for a career as writer and dramatist. We come back to him briefly at the end of the next chapter.

Having learned about Bandele's childhood origins, I made my way back to his first book, The Man Who Came In from the Back of Beyond (published under the name of Biyi Bandele-Thomas), from 1991. Here was a quite precocious author: he wrote this novel in his early twenties. On the cover of the paperback edition I have, there 
is a quote from a review in the Observer: "A story of Africa: exotic, sprawling, overcrowded and bizarre." The book was published in Britain by Heinemann, as were so many early African writers. (One could note that the series editor at the time was Adewale Maja-Pearce, another member-of-sorts of a Yoruba diaspora. We come back to him in chapter 18.)

I may confess that I was rather bewildered reading this book. It moves back and forth quickly between people and places and in other ways. Kafanchan serves as the setting occasionally, although there is never really a strong sense of the locale. But we learn this much: "The world is a small place and even smaller was Kafanchan, where the left hand was always aware of what the right hand was doing. A word here, a whisper there and anybody who had ears for the grapevine was immediately brought up to date on the latest news in town." There is also still that infighting between local Christian denominations.

The young man at the center of the story reads Buddhist scriptures and Charles Dickens, Lobsang Rampa, Jack Kerouac, Wole Soyinka, Ernest Hemingway, Booker T. Washington, James Hadley Chase, and Frantz Fanon. He listens to Bob Marley and to Fela Sowande. He gets to know the local marijuana tycoon but also nurtures plans for radical revolutionary violence. On visits to Kano, Kaduna, and Jos, he recruits altogether some fifty youths among the almajiri, boys begging in the streets, followers of itinerant Islamic teachers. (A few paragraphs are inserted into the story here on the very real Maitatsine rebellion in Kano in 1980, briefly discussed in chapter 13.) These intended foot soldiers of a rebellion are put up in an isolated house at the outskirts of Kafanchan for training, but when the local police get wind of their presence, the place is raided. The boys, caught in the act of training spear throwing, are arrested. But their leader is not there, having gone to Lagos to get walkie-talkies for them.

And so it goes. One gets a sense of the author as a young man, taking in all the experiences and all the news of his time, fashions and rumors, from near and far away. Returning to Bandele's later book: perhaps we can think of those "Burma Boys" as yet another set of been-tos, of Afropolitans. They were not of the kind who would go abroad to seek education, to further their careers. But they would also come back and play their part in the way Nigerians thought of the world outside. ${ }^{4}$ 


\section{Notes}

1. Those were good times for the Nigerian railway system; when we get to chapter 18 we find that two 1980s travelers did not have such pleasant memories from being on the rail, and some time after that the Nigerian railways closed down altogether.

2. Eze Goes to School was coauthored with Michael Crowder, a British historian long active in Nigeria, who was also for a period editor of Nigeria magazine.

3. Obafemi Awolowo was the leading Yoruba politician for an extended late colonial and postcolonial period, leader of the Action Group party, premier of the Western Region, and national opposition leader. Obafemi Awolowo University had started out as the University of Ife, but was renamed after him in 1987. See also chapter 10 , note 2.

Another important person in mid-twentieth century Nigerian cultural life, the artist Uche Okeke, also had part of his childhood in Kafanchan; later he was connected for a period to Ahmadu Bello University, Zaria. For one thing, Okeke drew the illustrations for Achebe's Things Fall Apart.

4. Okey Ndibe's (2016: 66-69) father was also in the Burma campaign, and remembered it. In a brief autobiographical postscript to The Palm-Wine Drinkard, too, Amos Tutuola noted that when as a young man he tried to get a foothold on the job market, he found it crowded by returning overseas soldiers. And, as we saw in chapter 1, Artur Lundkvist, the Swedish author and traveler, encountered them in the Lagos streets.

\section{References}

Bandele, Biyi. 2007. Burma Boy. London: Jonathan Cape.

Bandele-Thomas, Biyi. 1992. The Man Who Came In from the Back of Beyond. Oxford: Heinemann.

Ndibe, Okey. 2016. Never Look an American in the Eye. New York: Soho.

Nzekwu, Onuora. 1961. Wand of Noble Wood. London: Hutchinson.

. 1962. Blade among the Boys. London: Hutchinson. . 1965. Highlife for Lizards. London: Hutchinson.

Nzekwu, Onuora, and Michael Crowder. 1966. Eze Goes to School. Lagos: African University Press. 


\section{Nigeria at War}

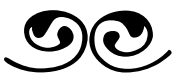

By the time I came to Kafanchan in the mid-1970s, the town had already been through some complicated history. Occasionally, as I lingered in the dining room of Rosy Guest Inn where I was staying, I would check the guest register lying on one of the tables. Straight columns drawn by pencil would ask for names, addresses, occupations, and then"tribe." Most visitors would obediently fill in the name of the group they habitually identified with: Hausa, Yoruba, Nupe, Tiv, or whatever. One morning, however, an angry reaction had been written in there. The column for "tribe," one guest had felt, had no place in a united Nigerian nation. It was evidence of an antiquated mode of thought, which must be abolished.

I suspect my friend the inn owner had merely copied his columns from the guest book at the local "catering rest house," in a chain of state-run enterprises of somewhat greater prestige, remnants of the colonial era. Yet it could hardly be denied that ethnicity, or "tribe" and "tribalism" as local discourse would have it, was still a major fact of life in the late twentieth-century social order. The national anthem adopted when Nigeria became independent was written by a British lady, a resident expatriate at the time, and had these lines in the first verse:

Though tribe and tongue may differ,

in brotherhood we stand.

That anthem was replaced in 1978, but it had hardly portrayed the recent history of the country. One might have thought that the expatriate author had no business highlighting the differences; in any case, there was not so much brotherhood. In the late 1960s, the deteriorating national politics of Nigeria had struck Kafanchan severely. After the first military coup in early 1966, led by young Igbo army officers, there 
were pogroms against Igbo settlers in the north. After a second coup, a countercoup led by northerners, the country fell apart. The southeast, fundamentally Igbo country, declared its independence as the Republic of Biafra, and a war broke out. ${ }^{1}$ (There was a petropolitics involved, as the secessionist leadership considered that the recently identified sources of oil were in large part on Biafra territory.)

The Igbo community in Kafanchan at first believed it was safe. After all, it was strong, numerically and in other ways. But then there were rumors that truck-loads of men eager for a fight were on their way from the north, and Emir Isa Muhammadu declared that he could not guarantee the safety of the Igbo in Kafanchan. So more or less all of them hurried away, in large part by train, leaving from what, in a way, had been their railway station. Far from all made it back to their homelands, since many of them were massacred on their way. As the Igbo left, Kafanchan became for a time something like a ghost town. The houses they had abandoned were ravaged. Doors and zinc roofs were carted away. When rainy seasons came and went, mud brick buildings fell apart. But by then, locals, and more migrants from elsewhere in the country, had begun to fill some of the empty spaces.

The Biafra War lasted several years, with much loss of life, leaving the Igbo destitute and hungry. Some of those who made their way to Kafanchan in the early 1970s were returnees; others were younger people who had actually never been there before. But, while some advantageous niches in the urban economy could not be reclaimed, quite soon they were back running a great many of the stalls in the Kafanchan market place. (I mentioned the Onitsha connection of this commerce in chapter 6.) As I engaged in small talk with many of them, listening to their reminiscences, dwelling in considerable part on Biafran triumphs and heroic deeds, the only thing that could seem puzzling was that it was about a war that their side had actually lost.

Inevitably, in the times that followed, the war would come to figure prominently in Nigerian writing. The war novel that would eventually draw the greatest attention was Chimamanda Ngozi Adichie's Half of a Yellow Sun (2007) - the title alluded to the design of the Biafran flagwhich did much to establish the author's international fame. She had already made her successful debut, of course, with Purple Hibiscus in 2004. Half of a Yellow Sun, however, was probably the most celebrated Nigerian novel since Achebe's Things Fall Apart (with her Americanah [2013] later coming in as the closest competition-see chapter 17). The central cast of five key persons is a microcosm of self-organizing diversity. To begin with, there is Ugwu, a houseboy evidently in his early teens, just arrived at the Nsukka campus home of his bachelor master 
Odenigbo, senior lecturer in mathematics (thus in the same discipline as Adichie's own father). Soon enough, Odenigbo's girlfriend Olanna shows up, back in the country with a master's degree in sociology from London, to pick up a job as sociology instructor at Nsukka. When Olanna goes back to Lagos for a brief visit with her parents-her father is a successful businessman there, making profitable, although shady, deals with the government-she also meets her twin sister, Kainene, who will soon take on running those parts of the family business based in Port Harcourt. Kainene is less pretty but has a sarcastic humor; perhaps she comes out as the strongest character in the book. Her rather shy British boyfriend, Richard Churchill, shows up soon enough in Nsukka, to do a research project on Igbo-Ukwu art. (His last name offers ample opportunities for "Winston" jokes.) So here is the entire transnational spectrum, from expatriate via been-tos to the servant boy fresh from the bush. There are other, less central people as well, such as Muhammed, Olanna's ex-boyfriend; he is still a friend, so Olanna takes the train to visit him and his family in Kano. She finds the sabon gari (the migrant quarter where most Igbo live) dreary, and admires the walls of the old city. The time, to begin with, is the early 1960s, not really anywhere close to the war yet. Still time for animated postcolonial campus conversations about world affairs and about the comparative qualities of British and American higher education, after breaking the kola nut - and for critical comments about Balewa, Northerner federal prime minister in power in Lagos, too inclined to listen to the British.

Forward now to January 1966. Ugwu, Nsukka-based for several years, visits his home village briefly, and senses his growing distance to it. Then comes the announcement of the first military coup. During the following months, the political and business terrain in Lagos is in upheaval, and the twin sisters' affluent parents take one overseas trip after another, while reflecting on how to manage their financial and social investments in the new situation. Gradually the situation in the North worsens for the Igbo. There are graphic mini-accounts of some of the atrocities. Olanna, on a family visit to Kano, has to have the help of Muhammed to get out of town. By the time she gets back to Nsukka, after a difficult, long journey by train and then a shorter journey by taxi, she is exhausted and falls ill. One high Igbo officer, very likely involved in the first coup and a childhood friend of Olanna's, also has to flee the North, hides in the outskirts of Kafanchan briefly, and then escapes concealed in another southbound train. As an expatriate, Richard is freer to move around in the country. Returning from London through Kano, he witnesses the murder of a young, friendly Igbo gate attendant at Kano airport. 
Nsukka is soon overrun by Nigerian troops. The story becomes one of evacuations and evacuations again; new postings in the Biafra administration; Kainene's and Olanna's parents relocating abroad once more; back in Biafra, families splitting apart as some hit the road and others do not; proclaimed instances of triumph; below-standard accommodation; air raids; and in between, moments of near normality and subtle negotiations over close but ambiguous relationships.

Now (surprisingly, but a smart move by Adichie) the book takes us back to the early 1960s again. This section offers backstage information for understanding these relationships. Ugwu goes to school, and has high hopes for his future. In his room in Boys' Quarters, he reads newspapers and magazines, and learns about things that have been beyond his horizon before. Olanna's and Kainene's mother gossips with her woman friends about other women's affairs and their own expensive consumer habits, and upbraids a newly hired but elderly servant, while her husband has a mistress living in a house he has provided. While Olanna is away from Nsukka, Odenigbo's mother moves into his house, complains about that woman friend of her son's who is most likely a witch, and brings a village girl, whom she gets into her son's bed for a brief sexual encounter. Olanna learns of this, is quite upset, and has her own one-night engagement with Richard, which in turn leads Kainene to break off her relationship to her twin sister-and to burn Richard's book manuscript on Igbo-Ukwu art.

Then back again in a new section to war time. Odenigbo does trivial although exhausting office work, but also joins the Agitator Corps to make patriotic speeches to villagers. Olanna teaches school. Kainene runs a refugee camp. Richard gets to write pieces for the Propaganda Directorate. Dull relief foodstuffs from the Red Cross, and a descent into poverty, with a new Biafran currency-pretty notes. Kwashiorkor, an illness caused by protein deficiency, spreads with obvious symptoms among the children. Opportunities for corruption and petty crime are plentiful in the interstices of the war effort. Odenigbo hears that his old mother has been killed, shot by "the vandals," and after he fails in his attempt to secure her remains, he turns more to drinking, at the Tanzania Bar, so named to honor one country that has recognized Biafra. Ugwu, around twenty years old by now, has faithfully followed his master's household even as its quarters have become increasingly cramped, but one day he is seized and forcibly recruited to a wild band of Biafran soldiers. Successfully killing a number of enemy soldiers in an explosion, he earns a new nickname as "Target Destroyer." Then, with his new peers, he participates in a gang rape of a bar girl. 
Now Ugwu is gone again, reported dead in battle. But that turns out not to be true; although injured, he returns, but he has largely lost interest in Biafra and its war. All five key persons are finally together again, getting along better than for some time, but times are very hard. There is little to eat, and although Odenigbo can drive in search for foodstuffs, the scarcity of petrol means that he cannot get far. As Biafra finally collapses, Kainene goes out to search for whatever might meet their most basic needs-but does not come back. She vanishes, and the search for her everywhere is hopeless. The remaining four make it back to their old house in Nsukka. It is in shambles. Odenigbo finds piles of his books burned. As Richard goes to Kainene's old house in Port Harcourt, a strange woman lives there, and orders him out. It has been turned over to her, defined as "abandoned property." Olanna's and Kainene's parents have returned to Lagos from overseas. But the book ends without Kainene. A final mystery.

Reading Half of a Yellow Sun, one may feel that Kainene and the other four central characters are indeed made to come alive, portrayed in depth, in their passage through their complicated personal ties to each other as well as the tumultuous war scene. It will remain a story of things falling apart in Igbo society once more, now in a postcolonial era. But then Adichie was born in 1977, almost fifty years after Chinua Achebe, several years after the war ended; so in a way, like Achebe's book, this was already historical fiction, portraying the experience of people in a generation before her own. In a postscript interview, Adichie says that she could draw on the memories of her parents, both of whom had lost their fathers in the war. Yet a lot more research had also gone into the book.

We could note that not so long after the book appeared, in 2014, Biyi Bandele, Kafanchan-born, familiar from chapter 14, turned Half of a Yellow Sun into a film. He had moved in his war coverage from Burma to Biafra.

Of those well-known Igbo writers who were themselves of the war generation, however, hardly anyone among the more prominent could really stay away from the topic. The first military coup was indeed more or less forecast by Chinua Achebe, in the novel $A$ Man of the People (1966), published at just about the time the coup occurred. But their writing about the war itself came mostly when it had been over for some time.

Cyprian Ekwensi's Divided We Stand was published in 1980, by Fourth Dimension Publishers in Enugu, but the back cover says that it was written eleven years earlier, "in the heat of battle." It focuses 
on one family. To begin with, one may recognize a kind of rerun of Ekwensi's Iska (see chapter 5)-there is a prewar romance in Kaduna between a young Igbo woman and a Northern man. Selina Chika has been to a convent school there, receiving "the Roman Catholic education that practically turns every girl into a nun." Then she has been a civil servant, although with the Northernization policy there is no future for her there. Her boyfriend is Garuba Zaria, Northerner, and a major in the Nigerian army.

As the January 1966 coup occurs, Garuba finds himself close to the coup leader, while Selina escapes by truck to the family home in the Jos sabon gari, where her mother is waiting. (We may recall that Ekwensi spent some childhood years in Jos.) The most central figure among the family members in the story, however, is her brother, Isaac Chika, a star journalist at the newspaper West African Sensation, and in Lagos with his family. (This paper was also in People of the City and in Iska.) Yet another brother, Ben, is also in Lagos as a businessman, but remains mostly more distant.

Ekwensi allows considerable space for the events leading up to Biafra's birth as a nation. In those times after the first coup when the Igbo officers seem to be in power, the Araba king is plotting in Kaduna with his associates. Then the pogroms break out all over the North, and the second coup occurs, that of Northern officers. The period that follows seems a bit two-faced: in the North, the violent, looting crowds call out for their own secession, while in Lagos, the military and the politicians want a united country under Northern domination.

In Jos, Selina's mother Agnes prepares to join the exodus to the Igbo homeland: "The streets were filling up with more Eastern people on the run from parts further north. They were carrying their children on their backs, their possessions on their heads, while their wounds were wrapped in rags" (Ekwensi 1980: 86). After a fruitless journey back to Kaduna and then Kano, Selina escapes by air, saved by a "tall white woman," apparently from something like the Red Cross. The family comes together in its generations-old compound in Nkissi, a village close to Onitsha. Pa Chika, eighty years old, has been living there for some time already, after retiring from his Jos business (which involved selling small arms, mostly for hunting purposes).

All over the East, telephone kiosks and telegram counters at post offices are crowded with people pleading with relatives who are elsewhere-Lagos, Benin, Jos, Osogbo, Kano, Kaduna, Katsina, Bukuru - to return home immediately. Ben and Isaac and their families make it back by different routes. Isaac, having left the West African Sensation, is soon with the Biafran Press Service. When he goes to a 
petrol station for fuel for his car, he runs into a white man, evidently a Reverend Father, buying two big drums of it. It turns out, however, that this is no Reverend Father, but a mercenary.

As Nigerian troops approach, the family has to be evacuated from Nkissi. It turns out that Garuba Zaria is one of the officers designated to lead the invasion of the heartland, with a son of an emir as his second in command. They do not agree on everything, but the son of an emir is "something of a god." On the Biafran side, brother Ben Chika is decorated for his bravery, but then he is killed in an ambush. The body is taken back to Nkissi. Planes flying in from Nigeria, some of them Russian, bomb everywhere, including schools. Selina is working for the Red Cross.

Isaac Chika travels with a Biafran delegation to a peace conference in Addis Ababa, hosted by the Organisation of African Unity, OAU. Sitting with the world press, he sees the Nigerian delegation entering "in outdated long robes that needed laundering." His Imperial Majesty Haile Selassie speaks in Amharic, immediately translated into English and French. In the evening, soul music plays in the bars and night clubs. Returning home, he finds his father harvesting his yams and cassava.

While Selina has found a new boyfriend, a freedom fighter whom she plans to marry, Garuba Zaria is wounded in battle and brought to the hospital where she works. They get to talk one last time before Garuba Zaria tries to escape and is killed. And then her fiancé is also killed, not even knowing that she is expecting his child. Entering the Biafran Press Service newsroom, Isaac meets a news flash that the Biafran forces have surrendered and that the leader of what had been his country has escaped, possibly to the Ivory Coast.

Divided We Stand is held together by the five members of the Chika family. One may not find Chukwuemeka Ike's Sunset at Dawn (1976) quite so accessible. A list of "principal characters" at the beginning of the book identifies twenty-six people. The plot seems somewhat unclear. In large part, the text is a running chronicle of, and debate about, the war-a debate between politicians, civil servants, academics, and businessmen. There is enthusiasm at the beginning, when the Biafrans even briefly launch a counteroffensive across the Niger River and get as far into the Midwest as Benin. Yet the Nigerians are moving in at several fronts, north and south. Nsukka falls, Enugu falls, Onitsha falls; Biafra is left with Umuahia as capital, and that is uncertain too. But the circle of companions, while bemoaning their losses, can see an advantage in the shrinking of their beer bellies-they fit more readily into their suits when there are occasions for putting them on. One of 
the highest ranking of them, Amilo Kanu, emerges as the person most central to the narrative. Initially he is under some suspicion since he is rather slow deciding that he is on Biafra's side, and thus has to give up on his Lagos life and medical career. He also has a well-educated Hausa wife, Fatima, and this complicates things. She does not take readily to evacuation to an Igbo village. Her Hausa facial marks do not help her make local friends either. Then, when she comes unannounced to join her husband in Umuahia, he has to hide his newly acquired local girlfriend. Later Fatima is evacuated to Libreville, in Gabon, a country reasonably friendly to Biafra.

The buddies go on meeting. Their conversations celebrate brilliant weaponry inventions by Biafran scientists, at the same time as they keep up a running commentary on places lost to the enemy (largely Hausa soldiers), as well as on the strange taste of new locally brewed or distilled drinks substituting for the old imports. It is getting more difficult to keep up optimism as enemy aircraft drop bombs here, there, and everywhere. Personal stances change. One friend with a prominent business past, hitherto insouciantly secular, announces that he has given up on girls and is joining an evangelical group under a leader called Brother. Later, to the others, a member of the group comments, "When a man like that begins to talk about going regularly to prayer houses and all that jazz, I fear something has snapped."

Amilo Kanu decides that instead of keeping his exalted organizational position as director for mobilization, taking him relatively close even to His Excellency the Commander-in-Chief, he should join the young soldiers on the ground. This makes him briefly a public hero. But a Nigerian plane seeks him out in his hiding place and drops a wellaimed bomb. Fatima is ordered back from Libreville to be informed of his death. Then soon the war is over, as Biafra has to capitulate. One survivor reflects somberly over the reunion with Nigeria and the future of the not-so-united country. The book ends with nine pages of notes: explanations, and translations of Igbo expressions.

Cyprian Ekwensi and Chukwuemeka Ike were in Biafra during the war. (Ekwensi, with his Northern diaspora background, may never really have lived there before.) Chinua Achebe traveled extensively abroad, not least in the United States, stating the case for Biafra to varied audiences. In his collection of short stories, Girls at War (1972), the title story is more or less about what the title suggests, while most of the other stories are earlier writings from what had already become a twenty-year career. In "Girls at War," consequently placed at the end of the volume, the youngish Biafra bureaucrat, Reginald Nwankwo, runs into the same young woman at three points in time as the war unfolds. 
There is early patriotic enthusiasm, then a descent into corruption, smuggling, currency manipulation, and loose living. The girl, Gladys, is with the civil defense, and then in the fuel directorate. In her circle, one goes to Libreville, Gabon, to shop for things like high-heel shoes. The reader may wonder if Gladys will run into Chukwuemeka Ike's Fatima there.

By 1983, Achebe published a small book, The Trouble with Nigeria, again with Fourth Dimension Publishers. He was nolonger so concerned with Biafra, and more with the larger first generation of Igbo and Yoruba political leaders-and finding the second generation following in their footsteps. There was now a civilian, elected government, and he had made an effort to engage with national politics, teaming up with the Northern reformist Aminu Kano in a new party. But now Aminu Kano was already dead. And as it would turn out, at the very beginning of the following year, the military would seize power again.

Then in 2012 came Achebe's There Was a Country: A Personal History of Biafra. In fact, the book is not entirely about the country that was, or the period in which it was a country. That takes up about half the book, which begins with Achebe's childhood and family life, and passes through the years before and after Nigerian independence. The narrative is rather artless, with a certain stream-of-consciousness quality, although it offers much detailed insider information about the overall conflict as well as about tensions within Biafra's elite. The comments on postwar circumstances are more brief. Published fifty-four years after Things Fall Apart, There Was a Country would be Achebe's last book.

Most of the writers of Biafra war fiction, in the generation who experienced it, were of the more urban, educated, elite or near-elite, and they also wrote in large part about Biafrans of such characteristics. (Adichie's Ugwu, the houseboy, is an exception.) In such writing, there would be little about, as Cyprian Ekwensi (1980: 5) would put it, "the kind of Biafran woman whose life rotated around planting seasons, harvest time, the price of gari in the market." But there was also a short (85-page) novel by Flora Nwapa named Never Again. Nwapa had already published Efuru (1966), a full-length story of strong Igbo women and troubled marriages. Never Again was first self-published in Enugu in 1975, then republished in the United States in 1992. By that time, it could take its place in an expanding feminist literary wave, in the African Women Writers Series from Africa World Press in Trenton, New Jersey.

With her husband Chudi, Kate, the woman who is the first-person narrator in this story, is hardly in the lower strata of Igbo society either. 
They have a car, so as they plan their escape from their town, Ugwuta (aka Oguta, Nwapa's home town), in a war-torn area, they have to hunt for a can of petrol in the black market. But Kate comes across rather as an antiheroine. She is not pro-Nigerian, but more of a skeptic. The military triumphs and the wonderful feats of inventive Biafran scientists as reported by official news bulletins do not match what she observes around her. It all seems rather like what would lately have been termed "fake news," although of a patriotic sort. Kate is more inclined to trust the broadcasts of BBC, even if people around her find such listening habits politically incorrect-BBC is with the enemy. It seems Igboland at war is no longer characterized by the sort of transparency portrayed some years earlier by the anthropologist Victor Uchendu (see chapter 3). But the corpses, and the vagabonds and madmen in what has become a makeshift Nigerian prison yard, are very visible. When Kate and Chudi are finally able to return to Ugwuta, somehow freed from the occupiers, they learn that the townswomen have gone to sacrifice at the shrine of the Woman of the Lake. This pre-Christian deity, they understand, is the one who really delivered their town from the furies of the Vandals.

One might have thought that at least a civil war could have made the Nigerian writers turn inward, toward the battle lines running through the country. In large part that is true. Yet even here, there are again and again those outside involvements: Britain and Russia siding with Nigeria; some Francophone countries ambiguously friendly to Biafra. There are, too, Richard Churchill, Kainene's expatriate boyfriend, in Half of a Yellow Sun, and that mercenary masked as a priest in Ekwensi's Divided We Stand.

Just about all the fiction writing about the Biafra War that I have come across is by Igbo writers. There appear to be no portrayals of the excitement of "Araba," the threatened Northern secession, nor of the ambivalence of a soldier like Garuba Zaria as he strikes into the homeland of Selina, the girl of his intimate past. The main exception is Ken Saro-Wiwa's Sozaboy (1985). Saro-Wiwa, from a part of Southeastern Nigeria that was not Igbo country, had studied English on a scholarship at Ibadan, then went to teach at the University of Nigeria at Nsukka, but left when Biafra seceded, and became a civilian administrator in a part of the Niger Delta after it had been reclaimed by Nigeria. Apart from Half of a Yellow Sun, his book is the most acclaimed of the novels of this war.

Sozaboy, however, is not so simply a pro-Nigeria, anti-Biafra story either. In fact, neither "Nigeria" nor "Biafra" are explicitly named anywhere in the book, and there are no ethnic designations. ${ }^{2}$ This is a 
first-person narrative, but soon enough that first person is there only as "Sozaboy," which is the generic term for "soldier boy." Not quite Standard English, obviously_but then the subtitle of the book is "A Novel in Rotten English." Saro-Wiwa offers an "author's note," in which he describes this as

a mixture of Nigerian pidgin English, broken English and occasional flashes of good, even idiomatic English. This language is disordered and disorderly. Born of a mediocre education and severely limited opportunities, it borrows words, patterns and images freely from the mother-tongue and finds expression in a very limited English vocabulary. To its speakers, it has the advantage of having no rules and no syntax. It thrives on lawlessness, and is part of the dislocated and discordant society in which Sozaboy must live, move and have not his being.

So here, then, some thirty years after Dylan Thomas described Amos Tutuola's style in The Palm-Wine Drinkard as “young English," and after that style drew the disapproval of educated Nigerian commentators, Saro-Wiwa can playfully exercise his own creativity, and academic specialty, in writing his book in a way where "rotten" may show some affinity to that "young." (It does not get so close to real pidgin as to become inaccessible to readers whose repertoire is confined to Standard English. Moreover, there is a five-page glossary at the end, explaining a number of terms and expressions.)

Sozaboy begins rather as comedy, on the local scene of the village Dukana, home of fishermen and farmers. There is the funnyman Duzia, who could have been a standup comedian, if he could only stand upbut he is a cripple. There is the aging Zaza, a veteran of the Burma war, who knows about soldiering: he spent that war in the jungle trying to find "Hitla," the mysterious pet enemy of his British superiors. Chief Birabee is corrupt, and there is the inevitable preacher, Pastor Barika. And there is Sozaboy's dear mother (there is no father around). Sozaboy is an apprentice driver, caring for a truck engine and looking forward to the day when he will get a license. The nearest metropole is Pitakwa (that is, Port Harcourt). Breaks there on the trucking journeys allow him to hang out at the African Upwine Bar, where he meets the young waitress Agnes, who has somewhat ambiguously spent time in Lagos but turns out to be also from Dukana and is now returning there. She becomes the love of Sozaboy's life, and moves in and marries him.

War breaks out, although to begin with it seems rather remote. But when the apprenticeship comes to look less promising, Sozaboy enrolls as a soldier at Pitakwa, indeed becoming a sozaboy. In short, he goes out with his mates to shoot at the enemy, but gets caught, 
and finds himself turned into a soldier on the other side, joining what was previously the enemy. Although he gets to use old acquired skills and for a while proudly drive a Land Rover, he reaches the conclusion that "war is useless nonsense and everything is just to cause confusion." "That foolish man Chief Commander General have told lie about enemy and no enemy." But as he tries to escape from all that, he just finds more chaos: people fleeing along the roads-slowly, slowly because they are too tired to go any faster; disfigured children displaying the symptoms of kwashiorkor; soldiers looting. The Red Cross is giving out food and supplies-but people like Chief Birabee and Pastor Barika lay their hands on all that and sell it for a handsome profit. One senior soldier who used to be his superior, now apparently switching sides in the war back and forth according to what allows the greater advantage, lines up Sozaboy and a number of other soldiers to kill them off with his gun, one after the other. But just before he gets to the final three, he runs out of ammunition. So they, including Sozaboy, run into the bush.

The war comes to an end. As he makes a final return to what remains of Dukana, knocking on doors to try and find out what has happened to his mama and Agnes, people look scared and slam doors in his face. Duzia, the old cripple, explains the situation to him. The villagers have consulted a juju oracle, who explained to them that Sozaboy is dead. If and when he shows up again, he must be an evil ghost. And nobody dares to be the person to tell this evil ghost that these two women were the only ones killed by a bomb, in the single air attack to hit the village. Learning that he has lost his dear ones, Sozaboy walks away from Dukana, not knowing where he is going.

Again, then, these people-Ekwensi, Achebe, Ike, Nwapa, SaroWiwa-were all adults during the 1960s, with their own experiences of the time of war. They kept writing about it, for another decade and more.

After Chimamanda Ngozi Adichie, there have been other war novelists of a postwar generation. Chinelo Okparanta, born in Port Harcourt in 1981, left Nigeria with her parents for the United States at age ten. Her Under the Udala Trees (2015) dwells on the lesbian relationship between an Igbo girl and an orphan Hausa girl toward the end of the war-thus combining two conflicts, as same-sex ties have themselves been widely disapproved of in the country. ${ }^{3}$ The New York Times Book Review, Wall Street Journal, and the Guardian all reviewed it favorably. Okparanta attended the Iowa Writers' Workshop, studying under Marilynne Robinson and others, to become a professor of creative writing at Bucknell University in Pennsylvania. 
A decade before that, Beasts of No Nation (2005) appeared, a brief first novel by Uzodinma Iweala (with enthusiastic blurbs by Salman Rushdie and from the New Yorker magazine), consisting of something like an imagined stream of consciousness of a child soldier at the margins of a war somewhere not really identified-but it could as well be Nigeria as anywhere else. (The choice of a first-person narrative may remind us of Sozaboy.) And while in an autobiographical endnote Iweala identifies himself as an American and mentions Jamaica Kincaid and Amitav Ghosh among his teachers in creative writing courses at Harvard, he notes that his two Nigerian immigrant parents would take him and his siblings back every year to the old country and the villages where they had grown up. They spoke Igbo at home. His father is a neurosurgeon; as it turns out, his mother is Ngozi OkonjoIweala, the renowned economist who came to serve two terms as Nigerian minister of finance, was at one point a strong candidate for the presidency of the World Bank, and is now head of the World Trade Organization.

As the Biafra war is taken up in the imagination of a later, diaspora generation, then, it becomes an Igbopolitan motif.

\section{Notes}

1. About the 1966 military coups and about the Biafra War a great deal has been written. A pro-Biafra reportage by the British journalist Frederick Forsyth (1969), published in the middle of the war, drew much attention. Among the works by Nigerians that I know of is a memoir by Ben Gbulie (1981), one of the young southern officers engaged in the conspiracy. Harneit-Sievers, Ahazuem, and Emezue (1997) offer "history from below," drawing on extensive interviewing and providing a view also of the seamy underside of the war, when underdisciplined Biafran soldiers did not always behave well toward their civilian compatriots. More recently, there has been an overview of the war by Gould (2013), who interviewed some main participants and portrays their personal backgrounds. One gets a sense of a rather anarchic war scene, with certain senior officers pursuing their own agendas.

2. The only clear reference by name to a political participant in the crisis is to one "Okpara," who is raising money for an army. This is presumably Michael Okpara, premier of the Eastern Region of Nigeria in the times before the first military coup. Sozaboy's "Chief Commander General" can hardly be anybody but Biafra's leader, Odumegwu Ojukwu.

3. At the end of the book there is an author's note pointing out that in 2014, President Goodluck Jonathan signed into law the criminalizing of samesex relationships, and that in Northern states the punishment is death by stoning. 


\section{References}

Achebe, Chinua. 1966. A Man of the People. London: Heinemann. 1972. Girls at War. London: Heinemann. 1983. The Trouble with Nigeria. Enugu: Fourth Dimension Publishers.

Adichie, Chimamanda Ngozi. 2004. Purple Hibiscus. London: Fourth Estate.

- 2007. Half of a Yellow Sun. London: Harper. 2013. Americanah. London: Fourth Estate.

Ekwensi, Cyprian. 1980. Divided We Stand. Enugu: Fourth Dimension Publishers.

Forsyth, Frederick. 1969. The Biafra Story. Harmondsworth: Penguin.

Gbulie, Ben. 1981. Nigeria's Five Majors. Onitsha: Africana Educational Publishers.

Gould, Michael. 2013. The Biafran War. London: I. B. Tauris.

Harneit-Sievers, Axel, Jones O. Ahazuem, and Sydney Emezue. 1997. A Social History of the Nigerian Civil War: Perspectives from Below. Enugu: Jemezie Associates: Hamburg: LIT Verlag.

Ike, Chukwuemeka. 1976. Sunset at Dawn. London: Fontana/Collins.

Iweala, Uzodinma. 2005. Beasts of No Nation. New York: HarperCollins.

Nwapa, Flora. 1966. Efuru. London: Heinemann.

- 1992. Never Again. Trenton, NJ: Africa World Press.

Okparanta, Chinelo. 2015. Under the Udala Trees. New York: Houghton Mifflin Harcourt.

Saro-Wiwa, Ken. 1985. Sozaboy. Port Harcourt: Saros International. 


\section{America Observed With Nigerian Eyes}

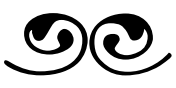

Nigerian commentary about American life, and Nigerians' own encounters with it, go back a long way.

We should understand the contemporary mobility of Nigerian Afropolitans between their West African home country and America in its wider historical and transnational context. John F. Kennedy, not yet president, himself of noted Irish ancestry, wrote a book in which he described his country as A Nation of Immigrants (1958). Despite its recurrent conflicts and divides, that nation has been quite successful in forming itself as an "imagined community."

A great many parts of the world consequently have their own stories of America-bound migrants, in literature as well as in personal biographies. One of the best-known literary works in twentieth-century Sweden, for example, was a quartet of historical novels about the nineteenth-century transfer of one modest Swedish farming family to a new home in Minnesota, and their settling in. ${ }^{1}$ In the twentieth century again, Sweden has had its own been-tos. For some of the returnees to the old country, the American sojourn became a parenthesis; for others it was central to their future lives and careers.

Conditions on the early emigrant ships from Europe to America could be dismal. But they were not slave ships. What was of course unusual about the West African migration to America in the twentieth and twenty-first century was that there had been those centuries of massive, dramatically involuntary transfer of people preceding them. A large part went to South America. We already encountered the traces of that in chapter 2, with "Mariana's story" of an Afro-Brazilian family in its back-and-forth moves between continents. Others came to the Caribbean islands and to North America. One important symbolic 
figure of that era is an Igbo, Olaudah Equiano (also called Gustavus Wassa as his slave name for a period, somehow drawn from the name of the sixteenth-century Swedish aristocrat-turned-monarch who had a major part in turning one part of Scandinavia into a country). Equiano's story may not be entirely clear; his own narrative covering much of the latter half of the eighteenth century includes his capture, a moment in domestic slavery not so far from home, then the traumatic journey on a slave ship across the Atlantic, a fairly brief stay in the southeastern parts of what had yet to become the United States, many years as a sailor under varied circumstances, and time in Britain as an anti-slavery advocate. ${ }^{2}$

Among the migrants to the United States have also been those from the islands of the Caribbean, such as Jamaica, with their own slave trade and plantation slavery past, and their own intricate relationships to the United States. (It was one Jamaican immigrant, Marcus Garvey, who led an early twentieth-century movement advocating a return to Africa.) They, and their descendants, are also now a part of the American social scene where African newcomers find themselves.

As Taiye Selasi came around to coining the twenty-first-century term "Afropolitans," her own personal connections were Ghanaian and Nigerian, but insofar as its reference is continent-wide "Afro-," we should also bear in mind that Africa-rooted literature is by now represented in North America by a wider range of writers. Ngugi wa Thiongo, celebrated Kenyan nationalist author, has continued to tell his stories about Kenya from a professorship at a university in California; and Alain Mabanckou, originally from Congo-Brazzaville, now has a similar academic base for his literary returns to Pointe-aPitre, his harbor hometown on the South Atlantic.

But Nigeria is a very large country, by African or any other standards, and so that is one reason it has so many commentators on life in America. And they go back in time. There was indeed Olaudah Equiano. In the introduction of this book we shared Nnamdi Azikiwe's memories of finding an overnight sleeping place in the New York subway. Then in the period of Nigerian independence, there was soon the pioneering volume of a new era in John Pepper Clark's America, Their America (1964). ${ }^{3}$ This was nonfiction, combining personal memoir with critical commentary.

Born in that part of southern Nigeria identified as the Midwest, to an Ijaw father and an Urhobo mother, Clark gained an academic degree at Ibadan in 1960, the year of independence; he was then a research fellow there, working also for the Ministry of Information and doing 
journalism for a daily paper while gaining a reputation as a playwright and poet. ${ }^{4}$

All that gained him an invitation to a one-year fellowship in the United States. Primarily he was to be based at Princeton University-at the time still showing the double face once personified by its president (and later American president) Woodrow Wilson: internationalist in the world out there, Southern white with aristocratic leanings at home. In large part, this was a finishing school for young Southern upper-class men in a period when the universities in their own region were not quite trusted with the job.

So here John Pepper Clark arrives, with his cultural and political sensitivities, trained in the late-colonial/postcolonial atmosphere of academic Ibadan and the Mbari Club (see chapter 6), and with a dash of youthful arrogance. There will be course work to attend to, but he will have opportunities to tour other parts of the country as well, relevant to his interests. Group visits are arranged to Washington, to the Congress and to the Supreme Court, with dignitaries present. And he has his own friendly contact with Langston Hughes, leading African American writer, whom he has already met at a Mbari Club event. There is some talk of a performance of Song of a Goat, Clark's play, as yet only shown in Nigeria (and published by Mbari), although that comes to nothing.

But then there is the more general question of how Americans relate to Africa. This is the time of the Cold War, and it is the wish of the United States to win allies in newly independent countries by what would later come to be described as "soft power," not least through varieties of cultural influence-such as making friends with people like Clark: "The constant concern of every American I came in contact with," he wrote, "from the professor to the professional hostess and even the publican, was to convert me, an unbelieving foreigner and African. Indeed the shock seemed to be that this was necessary at all; the gospel really ought to have reached and sunk into me already" (Clark 1964: 118-119). So the visitors are taught, or learn for themselves, about American history, and America's own North-South divide, and the advantages of free enterprise. And they see the toll highways, and experience the marvels of American kitchens-a topic of Cold War triumph in the "kitchen debate" that then vice president Richard Nixon had had, not so much earlier, with Nikita Khrushchev.

Yet Americans are too often woefully unprepared for well-informed dialogue with African interlocutors, as in this excerpt from a conversation at a Rotary Club meeting, with Clark as a guest: 
"Now Ghana is your capital city, isn't it?"

"No!" I said. "Ghana and Nigeria are two separate states entirely."

"No!" he fixed me with his fork. "Now that really is news. And is Nigeria north of the other then? Excuse my asking, but these new countries in Africa, they are creations of the British and the French, aren't they?" (Clark 1964: 134)

And from another conversation, with a young Black actress, who wonders why Clark wants to see the zoo:

"Why to see the inmates there," I explained. "I'm dying to see those lions, elephants, tigers and all my other wild cousins in there."

"You miss them?" Marlene looked real scared.

"Haven't seen any of them before in all my life," I disclosed.

“No, are you kidding? Don't those creatures crawl your village like automobiles here?” (Clark 1964: 136)

It is true that some Americans turn out also to have a somewhat hazy idea of the geography of their own country- "really a continent," as Clark also reluctantly has to admit.

Gaining some overview of educational exchange arrangements between the United States and Africa, he becomes increasingly critical. Too many young Nigerians are at American campuses who are actually needed at Ibadan, Nsukka, and Zaria, and who would be better off there. They might continue on in the United States to advanced degrees with academic topics for which there would be little use in Nigeria. More generally, Clark is invited to diverse gatherings with Americans, white or Black, but often exchanges at these become quite heated. He often voices criticisms of what the prominent sociologist Franklin Frazier (1957) had recently described as the "Black bourgeoisie." Then, in one such sociable setting, he overhears a comment evidently about himself: "Of course the young man may be a genius. But how can I possibly ask friends over to meet him when he shows such a penchant for making enemies?" (Clark 1964: 75). He has in mind going on a trip of his own to the Deep South to witness segregation and the civil rights struggle for himself, but is advised against it. If he were really to insist, he should at least wear one of these Nigerian robes, to show that he is not a Black American. But then that is a style he never uses, in Nigeria or anywhere. 
His hosts at Princeton indeed find him difficult to deal with. He does not attend classes for his assigned courses very regularly either, so, as the end of the academic year approaches, it is made clear that he risks overstaying his official welcome. He plays with the idea of ending his American year with an extended journey around the country by Greyhound bus, in this era offering especially cheap travel to foreign visitors (99 dollars for a month's unlimited travel). But he decides against that, and so friends see him off at New York's Idlewild Airport - to be renamed, before his book comes out, after the president who is assassinated some months after Clark's departure. His friends hope they will soon see him again.

So Clark returned to Nigeria for a prominent academic career at the University of Lagos. America, Their America was published in London. But, perhaps by then mellowed, he came back much later for visiting professorial appointments at leading American universities. He died in 2020 , at age 85 .

Understandings of Africa in the outside world continue to be spotty and uneven. In Chimamanda Ngozi Adichie's collection of short stories, The Thing around Your Neck (2009; a number of them previously published in the New Yorker and Granta), many dwell on Afropolitan themes. One describes the commotion at the visa section of the American Embassy in Lagos. ${ }^{5}$ Another is about Ujunwa, a woman writer representing Nigeria in a workshop for African writers in Cape Town-to be more exact, at a conference center at "Jumping Monkey Hill." She does not enjoy the company of the other writers very much, and gets irritated at the rather condescending manners of the ever-sohelpful white South African host couple. The wife suggests that with such exquisite bone structure, Ujunwa must be from Nigerian royal stock. Ujunwa just cannot resist such a provocation, so she confirms that she is indeed a princess- "one of her forebears had captured a Portuguese trader in the seventeenth century and kept him, pampered and oiled, in a royal cage."

The title story in the collection, however, is about a young Nigerian woman who finds herself working as a waitress in a cheap restaurant in Connecticut. A young male customer seeks her out, of xenophile sentiments, again and again, finds out that she is Nigerian, asks if she is Yoruba or Igbo, as she does not have a Fulani face. Who is he-a professor of anthropology at the state university? (No, it turns out.) She tries to avoid him but finally gives in. He tells her that he has traveled in Ghana and Uganda and Tanzania, and loves the poetry of Okot P'Bitek and the novels of Amos Tutuola. After he has taken her 
shopping at an African store to buy groceries, she prepares Nigerian dishes in her kitchen, and he ends up vomiting in her kitchen sink.

But most of the people she encounters at the restaurant have no idea about Nigeria. Since she is Black and speaks with a foreign accent, many assume she is Jamaican. Guessing that she is African, other customers tell her they love elephants and want to go on a safari.

Okey Ndibe arrives in the United States just over a quarter century after John Pepper Clark, but by the time his memoir Never Look an American in the Eye (2016) appears, he has already been established in the country for a long time, and has also just published two novels: Foreign Gods, Inc. (2014) and Arrows of Rain (2015)—more about the former in the next chapter. "Never look an American in the eye" is the advice he got from his uncle Ochendo before his first departure. The uncle explained, “Americans can't stand any stranger looking them in the face. They take it as an insult. It's something they don't forgive. And every American carries a gun. If they catch you, a stranger, looking them in the face, they will shoot" (Ndibe 2016: 33). Perhaps uncle Ochendo had the idea from American movies, since to the best of his nephew's knowledge, he had never met an American face to face.

Before Ndibe gets that far, however, his memoir sketches some of his early life and his family background. The book takes a somewhat zigzagging path through his biography, but let us reorganize it into a more straight chronology, even going back a couple of generations, to get a sense of the store of experiences and horizons already accumulated. His paternal grandfather had been a great wrestler and had worked as an artisan with British merchants at Warri, in the Niger Delta-what remained from this were a couple of Igboized loanwords: nimucomuроopu from "nincompoop," sukaliwagu from "scallywag." His father had been a World War II soldier with the Royal West African Frontier Force in Burma (we have seen more about that as a Nigerian experience in chapter 14). Just as the war ended, this quite outspoken lance corporal had made friends with a British lieutenant, who became a pen pal forever after, through good and hard times (the lieutenant returned home and became a reverend), and he also gained the chance to be trained in the postal services. So as postmaster and elementary school headmistress, Ndibe's parents were respected middle-class people in the town where he grew up. His father was a long-serving secretary of the town union, and in the late 1960s became a loyal Biafra patriot; but as he voiced his opposition to some of the activities of the Biafra regime, he was once placed in detention for several weeks (returning home with a new beard). 
Okey Ndibe himself was born in 1960, a few months before Nigerian Independence. He grew up learning of Britain, Obodo Oyibo, the land of white people-and of white magic, mystery, and power. Then a little later in his school years, there was talk of another important distant country, the Soviet Union. That was a place where according to comanizim, people owned everything in common. A remote white man named Kalu Mazi, with a big beard, had thought this up. The boy Ndibe was attracted by this as well.

To begin with, consequently, "America" came in only third place. Yet its influence would keep growing. There were those movies. Later in his youth he could buy copies of Time and Newsweek from street vendors. For more education he moved on to a college in Lagos to be trained in business administration. By then, however, he had found that he enjoyed writing, and soon enough he was working for a Lagos newspaper, the African Concord. He browsed in a bookstall in a local market place, too, and found books by John Steinbeck, Ernest Hemingway, James Baldwin, and others.

What made his life take another turn was a series of encounters with Chinua Achebe. A first fleeting contact had been when the famous author had happened to pass through Ndibe's boyhood home area. It certainly mattered more that later, as a journalist, he managed to arrange an interview with Achebe, then maintaining a home in Nsukka between his frequent stays in the United States. In a way, the interview was a disaster, as it turned out Ndibe's tape recorder had not worked. However, Achebe gracefully allowed a second attempt, and that probably made him remember that articulate young interviewer yet more clearly afterward.

And so, suddenly, while working away in Lagos, Ndibe receives an invitation from Achebe, American-based again, to come over as founding editor for a new journalistic enterprise, the African Commentary, conceived as a voice from the continent, a mouthpiece for the growing African community in North America. A first attempt to get an American visa is rejected; the second attempt succeeds through the brokerage of an American acquaintance in Lagos. Ndibe gets on a Nigeria Airways direct flight across the Atlantic.

He learns quickly that the New York winter is not like harmattan, the dry, cold wind that blows in over West Africa from the Sahara-it is much colder. He makes his way to the Massachusetts college town where he has his contacts, as mediated by Achebe. Among his first experiences is to be arrested as he waits at a bus stop-suspected of bank robbery, as his appearance matches the available description 
of the culprit. Apart from rather fleeting contacts with American life, however, he seems soon to become somewhat encapsulated in a network of Nigerian expatriates. Gate crashing at parties with other bachelors, he gets to one where he finds a well-known, somewhat more elderly Nigerian academic visiting, and engages in an extended conversation with him. But it turns out that this gentleman's daughter, a local resident too, is also present, and has Ndibe join her on the dance floor. They begin dating, and eventually they marry. The only problem is that she is Yoruba, and Ndibe worries that his parents will not approve. But it works out, and so these two Nigerian Americans find themselves in an interethnic marriage.

The African Commentary project does not work out equally well. It is very underfunded. The American-based Nigerian academics behind it are better at offering intellectual capital than coming up with financial capital: Ndibe and contributors are badly paid if at all, and it is difficult to find outside investors. (Bill Cosby, the entertainer, shows some interest but then declines.) Chinua Achebe's interest is uneven, and he eventually withdraws. The publication fails, and Ndibe turns to make his living as a teacher and journalist (writing for both American and Nigerian publications), but remains in the United States. In 1996, he takes the oath as a new citizen-"so help me God."

Does that mean that he has to become any less Igbo, any less Nigerian? Not in Ndibe's mind-"naturalization is not a loss-gain dialectic but a gain-gain proposition," he writes. True, he does not suddenly take everything American for granted, but can observe and comment. He is struck, for one thing, by a notion of "personal space." You do not just show up at even a good friend's home, for example, but you make an appointment. With that goes the special relationship Americans have with their dogs, "a man's best friend." Nigerian dogs are not treated like that.

He volunteers to tell African folk tales to classes in his children's school. Igbo trickster stories about the Tortoise, stories he had heard as a child, turn out to be very popular, as are his storytelling techniques. At the University of Massachusetts, he makes his way into the Master of Fine Arts program, where John Edgar Wideman, established African American writer, and one Hungarian exile are among his teachers, both very encouraging. The early manuscript of Arrows of Rain keeps being reworked and reworked. When Wole Soyinka, in exile in the United States at the time, comes through as a visiting speaker, he, too, gets a copy of the manuscript, which he promises to read. Ndibe waits for those comments, and, finally, when he comes back with his family from a half-successful Christmas party with friends (he has sorely 
missed Nigerian chicken-and-rice on the table), there is Soyinka's voice on the telephone answering machine, saying that he had found

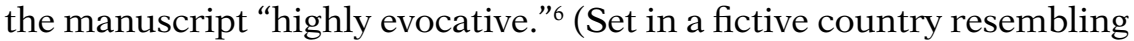
Nigeria, Arrows of Rain features a hero assumed to be a madman, of no fixed address but spending life on a beach, allegedly with a mamiwata lover, and becoming a witness of the serial murder of prostitutes. And a general has just proclaimed himself president for life.)

Life goes on, with large and small matters. Ndibe is irritated at the bad reputation Nigerians are getting globally, in part because of those " 419 " Internet banking scams. ${ }^{7}$ There is also the way his first name has a capacity to cause recurrent confusion, wherever Ndibe goes in the world. The full form is actually Okechukwu Ndibe, but it is common among the Igbo to use abbreviated forms-Chinua for Chinualumogu, for example-and Okey is a rather common version in Nigeria. But whenever someone whom he has not previously met is supposed to pick him up, and tries to identify him with the question "Are you Okey?" any stranger might hear "Are you OK?" and respond affirmatively. This happens at the airport in Trondheim, Norway, where a Ghanaian scholar going to the same Nordic Africa Institute conference on African literature gets the Ndibe treatment until the reception desk at the hotel points out that the real Okey Ndibe has already checked in.

All this time he makes regular home visits to Nigeria, to see his aging parents. At one point, he arranges a conference call so that his father can actually speak to his British pen pal, now an Anglican prelate, with whom he has corresponded since they met in Burma a half century earlier. The conversation is brief but cordial.

Then, not very much later, the day comes when there is an overseas call from his brother, telling him that his father has died. Okey Ndibe informs the reverend, and also arranges a journey to England for himself, to visit this family friend. He stays with him and his wife at their country home for a couple of days, reconstructing their interconnecting family pasts. The minister, it turns out, in those days when he was a young lieutenant, had actually not gone straight home from Burma, but had accompanied Northern Nigerian soldiers back to their home areas. And when he and his wife married in the mid-1960s, Ndibe's father had sent them a Hausa leather bag. Now they show it to him.

In sum, what have these American experiences of Nigerians beenand what have been the American experiences of the Nigerians arriving among them? A common theme is the striking lack of knowledge, and perhaps just as often ignorance taken for knowledge, of Africa 
and African life, probably especially among white Americans. Such experiences are sometimes amusing; at other times, simply irritating. John Pepper Clark's examples may be the most notable, although things did not necessarily get so much better with time. One could point out that there is some reciprocity of misunderstandings here: Okey Ndibe's uncle's premonition of what would happen if you look an American in the eye is a case in point. (American commentators have indeed been somewhat concerned about the ambiguities of soft power by way of Hollywood movies and other entertainment media.) Apart from such bumps and clashes, there are also those more subtle observations of the peculiarities of American everyday life, such as Ndibe's about "personal space," and personal relationships to dogshere we get varieties of ethnography.

For Nigerians spending some of their life in the United States, handling identity distinctions can clearly be a very complicated matter, situationally as well as over time. ${ }^{8}$ There is the question of what to do with the label "African." Perhaps one senses that this, as understood by many less-informed and prejudiced Americans, may even now carry overtones of "primitive." But there can also be an irritation over the fact that many evidently more well-intentioned Americans lack the knowledge of all finer distinctions, using the term as a kind of nationality label. Consequently one feels deprived of a recognized identity as "Nigerian," or even "Igbo" or "Yoruba." These may still become significant, of course, on occasions when Nigerians come together in the United States.

There is, too, the problem of being a Black newcomer, in a country where other Black people have had centuries of a difficult past. No doubt much of the time the difference between the African migrants and African Americans is clear, and understood as important; but then the reaction to being categorized as a generalized "Black" may lead at other times to a kind or degree of identification with them. John Pepper Clark seems a little ambivalent on this point, critical of the "Black bourgeoisie" and yet wanting to travel in the Deep South. He rejects the advice to don an African robe for such travel, to advertise that he is not a Black American. We may remember from chapter 3 that Victor Uchendu, at about the same time, employed that trick of identity management doing field research among Navajo Indians.

Perhaps at times Africans in America believe that their hosts' lack of any real knowledge of Africa is of a special kind, having to do with old and enduring prejudices. There may be something to this, but other visitors to the great country have more or less parallel experiences. It seems to be one implication of being immersed in such greatness that 
you may not stumble into much knowledge about other parts of the world, or seek it out either.

Move to another part of the world, and consider the view of a prominent Singaporean. ${ }^{9}$ Being from a quite small country, Singaporeans cannot so easily turn mostly inward-perhaps one could say that they will almost inevitably become "Singapolitans." By the time Simon Tay wrote Alien Asian (1997) in his thirties, he already had a growing public reputation at home. (Possibly one could compare him to the young John Pepper Clark several decades earlier.) The book drew on his columns "Fax from America," published regularly in the Straits Times, the leading Singapore newspaper, during a period when he studied for a law degree at Harvard University. But before that he had already been in a writer's program at the University of Iowa (the same one Amos Tutuola visited late in his life). Tay noted that his Asian and Asian American friends in the United States were where they wanted to be, but that many of them felt that Americans were keeping a distance from them. People he met, whose notion of Asia was hazy, could not quite figure out how Tay could be a Christian, rather than a Buddhist or something. And out of that feeling of otherness came the title for his book. "Aliens" was not only the official categorization for people who are neither citizens nor permanent residents; the term also suggested people who were "wholly different and perhaps dangerous." So the American mainstream had turned them into an opposite. In a later book, Asia Alone (2010), Simon Tay engages with future scenarios for the world. In a refashioned interdependency, he argues, globalization must read as "global-as-Asian," with the United States adapting to a new world situation. "Global-as-Asian" must penetrate Main Street, must reach those Americans who still do not take their shoes off when visiting an Asian home, and think sushi tastes better cooked.

While Nigerian eyes have been observing America, the eyes of Americans may occasionally have been observing the Nigerians arriving in their midst. ${ }^{10}$ Finally, we may attend to one such observer, of a certain prominence. This happens to be an American of Asian background: Amy Chua, now a law professor at Yale University, is American-born, the daughter of a young Philippine-Chinese couple who had recently arrived in the United States in pursuit of higher education. Like Simon Tay, she has written on scenarios for the global future, although what has contributed most to her public visibility is her book Battle Hymn of the Tiger Mother (2011), a memoir sardonically describing her toughminded childrearing practices-an international bestseller placing her on Time magazine's list of one hundred most influential people in the world. ${ }^{11}$ 
Chua, however, has also continually engaged with issues of ethnicity, in America and elsewhere. The Triple Package (2014), with her husband and fellow Yale University law professor Jed Rubenfeld as coauthor, is another rather controversial book about how three personal characteristics-a superiority complex, insecurity, and impulse controlhave made members of some ethnic groups more successful than others in American society. These are Jews, Mormons, Cuban exiles, Indian Americans (not to be confused with American Indians, "Native Americans"), Chinese immigrants, and Nigerian Americans.

With slightly finer distinctions, Chua identifies the Yorubaboasting "an illustrious royal lineage and a once great empire"-and the Igbo, and notes Chinua Achebe's warning to his people of "dangers of hubris." Indeed, it could seem that the portrayals by Victor Uchendu of the Igbo at home, in his anthropological case study (see chapter 3), and by Cyprian Ekwensi of the Igbo migrants in the North, in his novel Iska (see chapter 5), have now taken the flight across the Atlantic. ${ }^{12}$

\section{Notes}

1. Vilhelm Moberg's four novels about the Swedish migrant family were published in the 1940s and 1950s. Later, in the 1990s, a musical was also inspired by them.

2. The Interesting Narrative of the Life of Olaudah Equiano was first published in England in 1789. It has been republished in various forms and editions since then. Possibly the most readily accessible edition recently has been a selection in a series of Penguin classics (Equiano 2016). One might wonder what would have been a more likely Igbo spelling of the surname at the present time: Ekwianu?

3. Again, twenty years earlier Nwafor Orizu had also offered some comments on the United States, based on his student experience, in Without Bitterness (1944). See the introduction, note 21.

4. At times he also used the name form John Pepper Clark-Bekederemo.

5. There are parallels here to Charles Piot's (2010; Piot with Batema 2019) studies of the fixation on the American visa lottery among Togolese, who have become increasingly pessimistic about the future of their own country. By 2017, "visa lottery" had become another xenophobic scare concept broadcast from Donald Trump's White House, not least when linked to African immigration.

6. Evidently, Arrows of Rain had the longest history in manuscript, although it was not the first to be published. When Foreign Gods, Inc. appeared in print, it had blurbs by both Soyinka and Wideman on the front cover. Soho Press, which took on all the books, is a New York publisher with fairly cosmopolitan tastes.

7. The "419" scams are also referred to in chapter 9; for a reference to an academic source, see note 5 in that chapter. 
8. In his book Stigma and Culture, on the complexity of Black cultural identities in the United States, Lorand Matory (2015: 370-446), himself an African American anthropologist with extensive research experience in Nigeria (see, for example, chapter 2) and with a Yoruba spouse, devotes a long chapter to these intricacies. A recent acclaimed novel, Tope Folarin's A Particular Kind of Black Man (2019), offers an intriguing view. The protagonist is born in Utah, of Nigerian parents, without much contact with their country of origin outside his immediate family; his mother, suffering from mental illness, returns to Nigeria when he and his brother are young children. After some time, a stepmother appears, a young Nigerian widow bringing her own children. Moving around Utah and Texas with the family, the boy gradually becomes more familiar with Black Americans, but it is clear that his struggling father is not enthusiastic about identifying with them. Yet, as a successful college student at a famous Black institution in the South and at a prosperous college in New England, he comes to move in Black American circles. He finds a girlfriend in these, and she finally convinces him that he should visit Nigeria and seek out his ailing mother. So there he goes: Lagos, and a reunion with her and with the extended kin group.

9. In a book on global future scenarios (Hannerz 2016), I discuss the writings of Simon Tay and Amy Chua, among others, more extensively.

10. On my shelf I find another book that also contributes to the network of American-Nigerian perspectives, while involving yet another passage: Marita Golden's autobiographical Migrations of the Heart (1983). Golden grew up in Washington, DC, became a 1960s Black American student activist there at a largely white university, moved on to New York for journalist training and practice, met the young Nigerian Tunde and married him, and went with him to Lagos to begin married life. But that did not work out, as it seems Tunde expected her to fit into the scene as a Yoruba-style wife and mother. So Golden returned to the United States.

11. Apart from Battle Hymn of the Tiger Mother and The Triple Package, Chua's books include several others on globalization and ethnicity $(2003,2007$, 2018).

12. One could discern similarities between Chua's and Rubenfeld's view and the much earlier comparative study of achievement motivation among Nigerian ethnic groups by the psychological anthropologist Robert LeVine (1966). More recently, the Nigerian American sociologist Onoso Imoagene (2017) has also provided a positive view of the successes of secondgeneration Nigerians in the United States.

\section{References}

Adichie, Chimamanda Ngozi. 2009. The Thing around Your Neck. New York: Knopf.

Chua, Amy. 2003. World On Fire. New York: Doubleday. 2007. Day of Empire. New York: Doubleday. 2011. Battle Hymn of the Tiger Mother. New York: Bloomsbury. 
2018. Political Tribes. New York: Penguin.

Chua, Amy, and Jed Rubenfeld. 2014. The Triple Package. New York: Penguin. Clark, John Pepper. 1964. America, Their America. London: Andre Deutsch.

Equiano, Olaudah. [1789] 2016. Kidnapped. London: Penguin Random House UK.

Folarin, Tope. 2019. A Particular Kind of Black Man. New York: Simon \& Schuster.

Frazier, E. Franklin. 1957. Black Bourgeoisie. Glencoe, IL: Free Press.

Golden, Marita. 1983. Migrations of the Heart. New York: Anchor Press.

Hannerz, Ulf. 2016. Writing Future Worlds. New York: Palgrave.

Imoagene, Onoso. Beyond Expectations. Berkeley, CA: University of California Press.

Kennedy, John F. [1958] 1964. A Nation of Immigrants. New York: Harper \& Row.

Le Vine, Robert A. 1966. Dreams and Deeds. Chicago: University of Chicago Press.

Matory, J. Lorand. 2015. Stigma and Culture. Chicago: University of Chicago Press.

Ndibe, Okey. 2014. Foreign Gods, Inc. New York: Soho.

2015. Arrows of Rain. New York: Soho.

2016. Never Look an American in the Eye. New York: Soho.

Orizu, Nwafor. 1944. Without Bitterness. New York: Creative Age Press.

Piot, Charles. 2010. Nostalgia for the Future. Chicago: University of Chicago Press.

—, with Kodjo Nicolas Batema. 2019. The Fixer. Durham, NC Duke University Press.

Tay, Simon. 1997. Alien Asian. Singapore: Landmark. 2010. Asia Alone. Singapore: Wiley. 


\section{Transatlantic Shuttle}

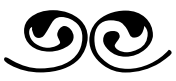

Sarah Ladipo Manyika's brief but highly acclaimed novel Like a Mule Bringing Ice Cream to the Sun (2016) can be seen as an instance of extreme Afropolitanism. Manyika grew up in Nigeria, then lived here and there in Africa and Europe, earned her $\mathrm{PhD}$ in comparative literature at the University of California, Berkeley, and is a San Francisco college professor. The central figure in her book is Morayo Da Silva, Nigerian expatriate, seventy-five years old, living since decades back in San Francisco, in a rent-controlled apartment with a magnificent view. Morayo had her early childhood in Jos, grew up in Lagos, and married a rather older Nigerian in the foreign service, whose family name she took. (Da Silva? That sounds like an old Lagos Afro-Brazilian family background.) She moved around in the world as the undiplomatic wife of a diplomat, then separated from him to move to America and become a literature professor. Her story is told mostly in the first person, with brief chapters here and there in the voice of a few people for whom she has become a relatively significant other.

The scene is San Francisco, with its ethnic diversity mixed with some American counterculture, such as in Haight-Ashbury.

The problem is that she is getting old. She has a wonderful personal library (idiosyncratically organized, forever being reorganized), but some of her longer conversations are with the Chinese mailman and with her own elderly car, with a manual stick shift and the affectionate name Buttercup. She is losing touch with the paperwork connected to the infrastructure of her life and may soon no longer be allowed to drive Buttercup. Some occasional thought about the future does not include returning to Nigeria. Lagos is very difficult, and if her very early memories are from Jos, that was a different place then, without any of the recent violent conflict between Christians and Muslims. Even Boko Haram is on her current horizon. She has made some donations to one charity organization in Nigeria, but that turned out to be a scam. 
There seem to be no Nigerians in the limited personal network she still has in San Francisco.

Morayo breaks her hip and has to spend a period in a rehab facility. One of her closest longer-term friendships has been with a younger Indian expatriate woman, who now tries to see to it that bills and related correspondence are handled, and that her apartment is cleaned up. In the process, however, a number of battered old copies of books in that treasured library are lost, and Morayo just cannot forgive her friend for this. So that relationship is broken. At the rehab, she develops new conversational acquaintances with one old Afro-Guianese who comes there regularly to visit his Alzheimer's-afflicted wife, and with a very talented cook from the Caribbean, named Toussaint. But her last exchange is with a young female street person, just before she heads out on the road with Buttercup.

Hitting the road is, of course, an old motif in American writing. Yet Manyika's book is not so much one about America, even as the San Francisco scene is important. It is more about getting old. (One might compare Morayo's aging with that of Baba of Karo, in chapter 12). In any case, Nigeria is not there much. This is a traveler with a one-way ticket. On the other hand, Like a Mule Binging Ice Cream to the Sun is published by Cassava Republic Press; so in a way we are back in Abuja.

Elsewhere in fiction with Nigerian American motifs, there is more back-and-forth mobility. It draws often on the fact that not all of the transatlantic traffic involves the sort of personal success stories that Taiye Selasi foregrounds as she first introduces the Afropolitans as a social category. ${ }^{1}$ E. C. Osondu's Voice of America (2010) is a case in point: the front flap of this collection of eighteen short stories tells us that it is about "two countries and the frayed bonds between them." (The back flap identifies the author as teaching at Providence College, Rhode Island, and notes that this is his first book.)

Here is a first story about boys in a refugee camp, with nicknames like "Orlando" and "Acapulco," drawn from the T-shirts they have been given by the Red Cross. They daydream about the possibility of being adopted by families in these places. But the boy who got a shirt saying "My Dad Went to Yellowstone and Got Me This Lousy T-Shirt" ends up with the nickname "Lousy." Elsewhere, young boys on school holiday in their home village listen to Voice of America together and hear about a girl in America asking for pen pals. One of them responds to the invitation and starts to fantasize about what can come of it; but after some letters have been exchanged, of course, nothing comes out of it.

Another Nigerian-based story is about a bar in Port Harcourt, where veteran American oil workers come together. But among them there 
is one young newcomer falling in love with a bar girl who turns out to be a mermaid, a mamiwata. That does not end well. Other stories by Osondu are about exaggerated claims about overseas success, occupationally or educationally, and their consequences back home; about underhanded ways of getting visas to enter the United States and stay there; and about complicated relationships between the sexes among Nigerian migrants in America, in and out of marriage, and perhaps involving some intruding new American partner. In our own chapter 5, discussing early Cyprian Ekwensi novels, we noted the absent overseas significant other as a recurrent motif in Nigerian fiction. We find it with Osondu as well.

Okey Ndibe's Foreign Gods, Inc. (2014), sited in New York and in Igboland (showing local knowledge of both), is centrally more a story of transnational commerce than of personal relationships, but turns out not to have such a happy ending either. Ike (short for Ikechukwu) has an economics degree from a reputable New England college, but he cannot get a job in the corporate sector without a green card, that entry ticket to a fuller American life. Besides, his heavy un-American accent does not help either. For thirteen years he has been a taxi driver in different cities along the Eastern seaboard, finally in New York. By way of marriage to one ebullient Afro-American woman, he eventually gets his green card, but the marriage does not last very long, and the divorce settlement more or less relieves Ike of whatever savings he had.

In New York magazine, however, he comes across an article about a fashionable antiquities trader named Gruels, running his enterprise Foreign Gods, Inc. in a corner shop in Greenwich Village. To begin with, Ike is not impressed, but then he gets an idea. He is going to kidnap Ngene, the pagan deity image of his childhood village, fly it across the Atlantic, sell it to Gruels, and make a small fortune.

Relying partly on a loan and a gift from an old acquaintance, Ike gets enough funds together for a return air ticket to Nigeria. He gets through the indignities of semiofficial corruption at the customs control at Lagos Airport, thinking that it had not been like that when he left so many years ago. And he continues, by way of a domestic flight and road transport, to Utonki, the village, and his mother's house. It is evening, and soon enough he is asleep.

At this point Ndibe inserts some thirty pages of historical return to the arrival of the first white Christian missionary to Utonki-this is back to a Things Fall Apart-style era of the beginnings of colonialism in Igboland. Stanton, the missionary, sets out rather arrogantly to gain converts to his faith, not entirely without success, although many villagers remain doubtful. But then there is loneliness and tropical 
illness. After a year or so in the village, he wades into the river for a bath one early morning, nude (to the astonishment of the villagers who soon also turn up), goes out midstream, and disappears. That, it seems, is the end of him.

Ike's old, frail mother reproaches him for not sending much money for her support during his American years, and forbids him from going to see his paternal grandmother (his father has been dead for some time) and his paternal uncle, who is now the priest in charge of the Ngene cult. Ike's mother, for her part, is now a staunch member of the Christian congregation in the village, and the divide between the adherents of the old cult and the Christians is now a major fact of village life. The mother admonishes him to be on time for the morning church service-although as he expected, Pastor Godson Uka himself turns up late. While he waits, he is introduced to a number of young damsels in the congregation, obviously ready for marriage. It is clear that the church hopes to possess him, body and soul. And more than that: the pastor, whom Ike has quickly recognized as an ill-educated bigmouth charlatan, requests a private meeting with him to suggest that this wealthy American son of the village make a very large donation to God for the purpose of building a fine new church. That will make him extremely rich when he returns to America. Ike tells him off in no uncertain terms, and leaves.

Next, he goes to see his uncle at the Ngene shrine. He finds him in the company of a number of rather diverse, and dubious, followers. There is also an old labor activist, who can still carry on about that ancient radical philosopher white man, Kalu Mazi, with a colossal beard that is now in the Guinness Book of World Records. They break a kola nut together. By now Ike momentarily feels a little guilt about the plan to steal Ngene and take him to New York, but he reminds himself that Gruels, the antiques trader, had pointed out that in a postmodern world, a god that did not travel was dead.

He has also discovered that nowadays a number of villagers have cellphones, so he could actually call them from New York.

In a heavy drinking session, the uncle tells Ike that Pastor Uka is a descendant of a bandit-turned-warrant chief in those past days of strange, ill-informed colonial governance (see chapter 3 ), and that the pastor himself has spent years in jail in Lagos before showing up in the village with his peculiar Christian practice.

People turn up to beg for money from the wealthy returnee: relatives, the now ugly woman who had been his first love but fell for a gangster instead. They bring their stories and their gossip, showing that there are now corrupt practices linking the village to the state capital. A schoolmate 
from long ago, now a successful politician, spends weekdays in Enugu and weekends in his enormous village house with a six-car garage. His liquor cabinet is extremely well supplied. He would not have had all that if he were entirely honest. There is crime, too, petty and organized, connecting the village to international drug smuggling. Pastor Uka's church and the Ngene cult have both been involved in offering sacred protection for such activity. Clearly, Utonki is no longer the old idyll, and that helps decrease Ike's moral scruples again. Moreover, if the Ngene sculpture should disappear, suspicions would quickly focus on Pastor Uka, rather than on the visitor from New York. At the priest uncle's house, there is also an encounter with a visiting historian, an Igbo with a British $\mathrm{PhD}$, with a booklet on the fate of Stanton, that early missionary, drawing on obscure London archives as well as oral history from the village cultists. Here is authoritative documentation on the historical importance of Ngene, which should increase value of the sculpture in the eyes of Gruels at Foreign Gods, Inc.

As his time to leave comes, Ike sneaks into the shrine on a dark night and removes the sacred sculpture as his uncle the priest snores in the chamber next door. On his journey back, of course, he has to bribe his way out through Lagos Airport. Returning to his New York apartment, he finds he cannot turn on the light in his apartment-he had forgotten to pay his electricity bill. And wherever he turns-his mail box, his email, his telephone answering machine-there seem to be debts. Big debts. He goes to sleep, and there is a nightmare about the missionary Stanton. Also, a terrible odor spreads through the apartment, and it emanates from the sculpture in its package. He realizes that having taken charge of it, he is now the cult priest, and he has to take care of Ngene.

A telephone call from his sister back in the village informs him that after the disappearance of the sculpture there has been a violent clash between church and cult followers. Pastor Godson Uka has been badly beaten up, and Ike's mother has suffered injuries and is in urgent need of hospital care, which will be expensive. Ike promises to send money.

$\mathrm{He}$ needs to hurry to meet antiquities dealer Gruels at Foreign Gods, Inc. Yet Gruels turns out not to think much of the sculpture, is unimpressed with the scholarly documentation of Ngene history, and points out that "African gods are no longer in vogue." When he asks how much Ike wants for the sculpture, Ike responds "350,000 dollars," but Gruels' final counteroffer, before he has to rush off to an appointment, is $\$ 1,500$. He writes out a check.

Then after some days (he is beginning to lose track of time), when Ike has begun to regret selling Ngene, his telephone rings. There is 
Gruels's voice. Gruels says he immediately recognizes that African accent, and says he had been surprised to sell Ngene so quickly to a Japanese customer, who has already flown home, and who paid cash, so he could not be traced. Anyway, as Gruels got a good price, he was now prepared to add some to the amount he had paid Ike-at a stage when Ike, identifying himself as the new priest of Ngene, actually had in mind buying the sculpture back and returning it to the village. We learn no more.

So this is a dark story, at both New York and Utonki ends, at times funny, but not the sunshine story of future Afropolitan success that both Ike and his parents must once have dreamed of.

Chimamanda Ngozi Adichie can offer at least a bit more of that. Her Americanah (2013) is, in part, the story of two Igbo returnees to Lagos. Perhaps we come to think of their predecessors Obi and Clara coming off the boat together in Chinua Achebe's No Longer at Ease-as beentos who had briefly met in London, but who only became seriously involved with each other on board.

Time has passed, however. Here and now Ifemelu becomes the "Americanah" who has spent an extended period in the United States, and that takes up a good part of the book. For much of the same time Obinze had ended up in London instead. But before that, they had already been schoolmates, and girlfriend and boyfriend, in Lagos. Again, in Americanah, for many years, there is that absent overseas significant other.

But this is a big book, approaching five hundred pages, with fiftyfive chapters. As chapter 1 begins, Ifemelu is journeying from sedate, odorless, academic Princeton to Trenton, nearby New Jersey state capital, to have her hair braided at a salon in a down-market Black neighborhood. She hopes the taxi on the final stretch will not have a Nigerian driver:

because he, once he heard her accent, would either be aggressively eager to tell her that he had a master's degree, the taxi was a second job and his daughter was on the dean's list at Rutgers; or he would drive in sullen silence, giving her change and ignoring her "thank you," all the time nursing humiliation, that this fellow Nigerian, a small girl at that, who perhaps was a nurse or an accountant or even a doctor, was looking down on him. Nigerian taxi drivers in America were all convinced that they really were not taxi drivers. (Adichie 2013: 8)

This could seem like a comment on Ike in Ndibe's Foreign Gods, Inc.

Spending hours getting braided and listening to the talk of those rather more Francophone African hair stylists (from Senegal and 
Mali), Ifemelu thinks about the decision she has just made, to return to Nigeria, after thirteen American years. She has just sent off an email to Obinze, that boyfriend of long ago, to let him know. Her current Black American male friend (academic, teaching at Yale) would be left behind, although he would possibly join her later.

Obinze opens the message on his BlackBerry, seated in the back of his car behind his driver, on his way home, and wonders what it really means. From here on the story, about two people for a long period with an ocean between them, and with the present textually mixing with reminiscences, moves easily in space and time. Ifemelu grew up in Lagos. Her mother moved between church congregations making different demands. Her father, more secular and intellectual, lost his job when he refused to act deferentially to a new female boss. In Ifemelu's teenage friendship circle, a new boy showed up, fairly short but very nice. His mother, a widow, was a university teacher at Nsukka. Rumor had it that she had been in a physical fight with a colleague, okay for a market woman perhaps but not for a scholar, and had therefore been exiled to Lagos. That was not quite true-she was really in Lagos on a sabbatical. Anyway, her son Obinze and Ifemelu found each other very quickly, in part over a shared taste for James Hadley Chase mysteries. She had a harder time when he tried to make her read Huckleberry Finn.

Some years later they went off to Nsukka together as students. Obinze had really wanted to go to Ibadan, having read a poem about it by John Pepper Clark. But his mother was not in good health, and as she returned to her old position in Nsukka, he felt an obligation to look after her. They came to like Nsukka, unimpressive as it has first seemed to them. Nigerian universities, however, were a mess. Staff salaries were not being paid. There were recurrent strikes. America stood out as an alternative, if one could only get a visa. Ifemelu got one, on the basis of an offer of a rather meager scholarship-but Obinze, who had planned to come after, for graduate study, did not.

Ifemelu's passage through multicultural America takes up much of the book. Complementing the scholarship with odd jobs, she would get a range of close-up views of urban America, but also of college life-she felt that American students were taught to talk much without really saying anything. From Nsukka she was used to more intellectual rigor.

As time passed, she would come to move in different circles: at times mostly with white people, more continuously with other Africans and with Black Americans. She would get to know Philadelphia, Baltimore, New Haven, and then Princeton (much different from what it had 
been when John Pepper Clark was there some fifty years earlier) on that fellowship. She would cook Nigerian food to commune with Africans, and to impress others with an exotic cuisine. There would be romantic involvements, for one thing with a white, affluent software entrepreneur, for another with that successful Black academic who just might follow her to Nigeria. Language mattered. She picked up American Standard English, but then was pleased to revert to her West African accent to demonstrate her identity. Among Black Americans she noted that mostly some of those of more mature age could codeswitch between the Standard and what was occasionally, politely or demonstratively, referred to as "Ebonics" (and which others might think of as the language of the ghetto). Black hair styles also continued to matter: braiding, cornrows, Afros. Her parents came to visit briefly, and she was a bit embarrassed at their lack of sophistication in meeting everyday America.

Basically it was an upward passage. Ifemelu's multifaceted outsider observations of the racial scene, and not least of the experiences and preoccupations of Black Americans, evolved into a blog, which gradually became a paying proposition, so she could quit doing other jobs. There would be speaking engagements as well (mostly, it turned out, lecturing to people who did not read her blog). So there she was, close to the point where she could choose to take United States citizenship, when she decided to return to Nigeria. It was the early, enthusiastic Obama period of campaigning and eventual election triumph. Even so, she left.

Meanwhile, long ago by then, the young Obinze had been turned away at the American Embassy in Lagos, again, again, and again. Finally, his mother, going to a conference in the United Kingdom, took him along as a "research assistant," which at least allowed him a sort of visa. And then she left him in London. That visa, of course, expired soon enough, and so he continued his British life doing lowly jobs (such as cleaning public toilets), sometimes on identity papers belonging to someone else, avoiding officialdom, occasionally sneaking into a bookshop to browse. Mostly he was in a circle of other Nigerians-some old acquaintances from Nsukka, some new, more fleeting contacts. But he felt lonely. Through middlemen he tried to find some woman with her papers in order whom he could marry and thereby fix his immigrant status. Just as the wedding was about to take place, however, he was seized by the police, who had received a tipoff about his illegal presence. He was marched off in handcuffs, held until there was a place for him on a Lagos-bound plane out of London-Heathrow. In a back row he had the company of some other 
Nigerian deportees, and, at Lagos Airport, had to pay a small bribe to immigration desk staff.

As Obinze thus returned to Lagos, he was basically without means. But a well-connected relative put him in touch with a super wealthy business person, a Big Man. Working for him, and forming his own diverse partnerships, Obinze gradually made his own fortune in Lagos real estate and in other fields, even though it was a style of life he did not always enjoy. The girl he married seemed to have no sharp edges, but became the perfect hostess and sociable party mingler. When their baby girl was born, she was soon enough seeking opinions about what would be the best school-in Lagos but with some expatriate curriculum.

So Ifemelu, the "Americanah," came back. In some ways, it was a different Lagos than the one she had left. It had become a place where everyone had a mobile phone: her hair braider, the plantain seller. She found a job with Zoe, a women's monthly magazine, paid two years' advance rent for a modest apartment, and made her way into circles in large part consisting of returnees like herself. She was talking to one of them, a colleague at Zoe, when another of them came in and entered the conversation:

"You people must be discussing the next Been-To meeting."

"What's that?" Ifemelu asked.

"Doris talks about them all the time, but she can't invite me because it is only for people who have come from abroad." If there was mockery in Zemaye's tone, and there had to be, she kept it under her flat delivery.

“Oh, please. 'Been-To' is like so outdated? This is not 1960," Doris said. Then to Ifemelu, she said, "I was actually going to tell you about it. It's called the Nigerpolitan Club and it's just a bunch of people who have recently moved back, some from England, but mostly from the US? Really low-key, just like sharing experiences and networking?" (Adichie 2013: 405)

Meanwhile Obinze is still waiting to hear from her. He wonders what she would be like now: "There was a manic optimism that he noticed in many of the people who had moved back from America in the past few years, a head-bobbing, ever-smiling, over-enthusiastic kind of manic optimism that bored him, because it was like a cartoon, without texture or depth. He hoped she had not become like that" (Adichie 2013: 371). Eventually they are back in touch. They find each other still very close, their best company in every way. Yet between sharing 
and obligations, things are complicated. Obinze travels alone to Abuja, a remote place with other habits where Ifemelu had never been. Then everybody is back again in Lagos.

The "tragic hero" motif of such early been-to stories as Achebe's No Longer at Ease is not there in Americanah, not in its clear-cut form. It is a story that shows much of the variety of ways of life that can be the outcome of transcontinental traffic, with its difficulties, pleasures, and ironies. It seems that Americanah draws a great deal on Adichie's personal experience-not least in its close attention to cultural detailwithout being a disguised life history. ${ }^{2}$ Unlike many of the other stories on the transnational theme, it ends in Nigeria: Obinze and Ifemelu both return to Nigeria, while Sarah Ladipo Manyika's Morayo and Okey Ndibe's Ike in their different ways continue in American lives.

Unlike Manyika and Ndibe, Adichie has evidently kept stronger Nigerian attachments. True, her Nigerian husband has his medical practice in the United States, and, for the time being at least, she spends much of her time there and engages with American life. In July 2016, the New York Times Book Review published on its front page her satirical short story about Melania Trump's preparations before the convention where her husband Donald would become his party's presidential candidate. Adichie is an elected member of the American Academy of Arts and Sciences. Yet she also maintains a home in Lagos and thinks that she might want to raise her daughter there. In October 2020, she wrote in the New York Times, from her Eastern Nigerian homelands, to state her support for those demonstrators against state violence who were bringing upheavals to Lagos, Abuja, and many other Nigerian cities, and who were being shot at by soldiers. Under President Muhammadu Buhari's leadership, she wrote, "insecurity has worsened; there is the sense that Nigeria could very well burn to the ground while the president remains malevolently aloof." A few weeks later, she reviewed Barack Obama's new memoir for the same paper.

Perhaps Adichie has found her own combination: in an interview with the Financial Times, she laughed and said, "We in Nigeria have an unearned and funny sense of superiority. Nigerians are the Americans of Africa." Beyond both Nigeria and America, however, especially since Americanah, and since she also began engaging in feminist advocacy, Chimamanda Ngozi Adichie has been globally successful, welcome as a public figure more or less everywhere. (I was in the audience for her appearance at one literary event in Stockholm.) The website Chimamanda.com announces that Americanah has been licensed for publication in twenty-nine languages. 
Teju Cole, the other best-known Nigerian/Afropolitan writer in recent times, has moved along a similarly globetrotting track. (I just missed his appearance at a similar public event, at a famous art exhibit outside Copenhagen.) Unlike Adichie, however, he already started out in life in the United States-he was born in 1975 (and is thus two years older than Adichie) in Kalamazoo, Michigan, of Yoruba parents, as his father was finishing a master's degree in business administration. (His birth name, according to a Wikipedia entry, was Obayemi Babajide Adetokunbo Onafuwa.) Soon after, they were all back in Lagos. But as a birthright, unlike his parents, little Teju had American citizenship.

In his early years, that did not matter so much. He grew up as a middle-class Lagos boy. Yet in the early 1990s, not a happy period in Nigeria, his parents decided to send him back to the United States; and so he was back in Kalamazoo for college (and a side job at McDonald's). He may not have remained in that town for so very long, but he moved on within that native country of his for many years that followed (trying medical school briefly, but also spending some time on African art history at the School of Oriental and African Studies, London).

Aged thirtyish, he was back in Lagos. His first book, Every Day Is for the Thief, was published by Cassava Republic Press in 2007, drawing on what he had first written for a blog. Then, after his Open City (2011) was a great success in the United States, his American publisher issued an edition of Every Day Is for the Thief "in different form" in 2014. ${ }^{3}$

Every Day Is for the Thief is described on the title page as fiction, but it is hardly recognizable as a novel. There is not much in the way of a plot. In twenty-six brief chapters, it portrays life in Lagos, with chaos, corruption (beginning as usual with the narrator's arrival at Lagos airport-as he has been away in the United States for many years), everyday criminality, and material neglect. The book is illustrated, too, with the author's own photographs. Cole has established himself not only as an author, but as a major photographic artist and commentator.

Then with Open City, Cole is in New York. The "I" narrator-not Cole himself, but a fictive somebody-lives in Manhattan. He can observe flocks of geese and other bird life through his window, but is in large part a flaneur on Midtown streets. As he reports knowledgably on what he sees, one gets a sense of what kind of person he is; but not in terms of simple social classifications. Only some comments on a walk through Harlem may suggest that this is someone different from those ordinary white Americans who would mostly not venture there, or see what he sees. But then, in chapter 2, what he sees makes him think of Olodumare and Obatala, Yoruba deities, and so something about his 
cultural identity is revealed. He also mentions a patient of his, so he is evidently some kind of doctor.

With time, more of his past and his identity are revealed. He goes by the first name of Julius. His second name, Olatobosun, is not really in use. He is named Julius after his mother, Julia, who is German, born in 1945 just as Soviet troops were moving into Berlin and World War II was over. Then she grew up in Magdeburg, in East Germany. She did not get along with her mother, Julius's Oma (who came on one visit to Lagos, where Julius had somehow formed a largely wordless bond with her), or with her Nigerian husband, and that probably was a background factor when they sent Julius off to a military-sponsored secondary school, a boarding school, in Zaria. While he was there, his father died of tuberculosis, so there he was with his mother, the German woman, a widow in Lagos. Julius discreetly started to apply for scholarships in the United States and was lucky to get one. Then, through diligent study, he became that New York doctor, active in local health care.

One way that Julius made cities-first New York, then others-open up was to reflect on the pasts, often dark, of the neighborhoods he walked through. Moreover, it seemed to happen again and again that those minimal fleeting service encounters that were a part of urban living turned into conversations, and sometimes more. Through his rather ambivalent relationship with his slightly physically handicapped woman friend, he became active in the Welcomers, a volunteer group trying to help undocumented immigrants from different corners of the world, held in detention after arrival in the United States. He maintained contact, too, with a professor from the college he had first come to. This man was a specialist in early English literature-but early in his life, as a Japanese American, he had been among those interned in a desert camp during World War II. Much later, as gays were beginning to earn recognition and rights in America, it turned out that this elderly professor was also one of them.

So far this has taken Open City to North America and to Africa, and back again to America, but that is not enough. Julius wanted to find his Oma again, and believed she might be in Brussels. Taking prolonged winter vacation time, he flew across the North Atlantic. Brussels, he found, had dark spots in its history, and was torn by old and new ethnic divides. The attempt to locate Oma failed, but on the other hand he soon found a conversation partner at the Internet and telephone shop where he had to make frequent visits, first trying to track down that grandmother, then just keeping up with his email. Farouq, a Moroccan in charge of the shop, knew about contemporary North African 
writers-one, he said, wrote mostly for foreign readers; another wrote for compatriots. Then Farouq also drew him into local networks, in large part composed of other immigrants of intellectual inclination, drinking excellent Belgian beer in cafés, and commenting more or less critically on Deleuze, Fukuyama, and Benedict Anderson. (Perhaps one could sense here that the kind of American readers drawn to Open City would find it appealing that they and those Brussels postcolonials were reading and talking about the same authors.) Farouq turned out to be another struggling academic. He had once submitted a thesis for approval at a local university, but that was just after $9 / 11$ in 2001. At a time of ubiquitous mistrust against Muslims, he had been suspected of plagiarism.

Back in wintery New York, Julius tried to reestablish contact with his past woman friend, but it turned out she had moved to San Francisco. A telephone conversation revealed that she was about to get married to a Haitian American, so Julius had better not call again. Belatedly, he learned of the death of his old Japanese American professor. Back on the streets, he had the experience of being mugged by two young thugs. He lost his wallet and his mobile phone, and was slightly hurt, but what impressed him was the careful choreography of the mugging.

Toward the end of Open City, Julius was back to bird-watching again, after a fashion. He had happened to get on a tourist boat cruising through New York harbor waters, and admired the Statue of Liberty from a distance. In earlier, nineteenth-century days, when there had also been a lighthouse on that small island, it had attracted all kinds of birds-which thus flew into an early death. The carcasses were passed on to scientific institutions.

Open City established Teju Cole's prominence. Yet the book that says most about Cole himself and his accumulating, under-construction view of the world is Known and Strange Things. This is a collection of essays, previously published in the Atlantic, the New Yorker, Granta, the Guardian, the New York Times and elsewhere. A number of them are about photography-reviews and commentary. One is about the outstanding Malian photographers Seydou Keita and Malick Sidibé. Connecting to literature, Cole follows in the 1950s footsteps of James Baldwin in the snow of the Swiss Alps. He also moves among Nobel Prize winners: there is an intellectually tender dinner conversation with Vidia Naipaul in a penthouse apartment on the Upper East Side, New York. He shows his admiration for a Swedish poet, Tomas Tranströmer, belatedly given recognition by the Swedish Academy, hesitantly due to criticisms following earlier awards to compatriots. ${ }^{4}$ And he visits Wole Soyinka in his Abeokuta home, the elderly colleague as vital as ever, at 
the time recently in the news due to his campaign against the civilian Nigerian president at the time and his corrupt, voluptuous wife from the Niger Delta: "You can take a hippopotamus out of the swamp, but you cannot take the swamp out of the hippopotamus." (One could note that meddlesome, high-living head-of-state spouses, "First Ladies," have repeatedly come in for public scorn in Nigeria, starting perhaps with Victoria Gowon in the 1970s.)

His journeys in and outside the United States take Cole to Selma, Alabama, remembered since the 1960s civil rights struggle (the earth is red like West Africa's); to Arizona and the border zone with Mexico; to Rome under Prime Minister Berlusconi; to Jerusalem, between Israel and Palestine; to Rio de Janeiro, where he converses with a trader from Senegal selling trinkets, printed cloth, and other goods from Africa. But the trader turns out to be actually a journalist, just trying to earn some money to go to a Brazilian university for a degree. Cole, for his part, reminisces about the cultural and historical links between Brazil and Nigeria, still evident in religion and food in one country, and in architecture and family names in the other. (We saw some of that in Mariana's story, in chapter 2, and with Soyinka's visit to Salvador, in chapter 11.)

In November 2008, on election night, Teju Cole is in Harlem, watching television in a bar. CNN flashes the graphic announcing "Barack Obama, Projected Winner, President." Outside on 125th Street, in a moment, there is a marching brass band playing "When the Saints Go Marching In."

And then he remarks that "Obama, at the core of his experience, is hybrid" (Cole 2016: 250).

One is tempted to say that in Known and Strange Things, Cole emerges as a renaissance man-but perhaps that is a concept with too strong historical Eurocentric connotations. In any case, his map of the world can connect recent events with past intellectual referencesviolent urban crowds in Nigeria, for example, with Bulgarian (and again a Nobel Prize winner) Elias Canetti's classic interpretation, from a half century earlier, of the instant achievement of equality in mobs. His close involvement with photography and his experience of blogging grow into an awareness of the future possibilities of communicative practices: "I am not saying there will be a Nobel Prize for tweeting, but ..." (Cole 2016: 90) In America, he shows how immigrants or longterm visitors, having assimilated as much of a local cultural repertoire as any native is likely to have, can yet go beyond that to insights that the native probably will not have. Cole takes the writings of a liberal New York Times columnist as a point of departure in debating "the White 
Savior Industrial Complex," a sense of superiority that sometimes goes with good intentions. Yet in cultural critique, he is nuanced, aware of complexity, showing less of the overt arrogance that evidently John Pepper Clark once exhibited in his interactions with American hosts.

In an interview Cole (2016: 84) has this to say: "My identity maps on to other things: being a Lagosian (Lagos is like a city-state), being a West African, being African, being a part of the Black Atlantic. I identify strongly with the historical network that connects New York, New Orleans, Rio de Janeiro, and Lagos. But, as a subject, Nigeria won't let go of me." On the one hand, one may conclude that Cole's Afropolitanism expands into an even more inclusive cosmopolitanism. His Afropolitan horizons are open in all directions. On the other hand, longing for his childhood home and missing his parents, he can turn to Google Maps-and in a moment he is there, on the street in northern Lagos, with the tree in front of the house, and the surrounding fence. At the back of his mind there is a Yoruba tongue-twister from his childhood: "Opolopo opolo ni ko mo pe opolopo eniyan l'opolo l'opolopo" (Many frogs do not know that many people are very intelligent).

The epithet "rootless cosmopolitan" has been around for a long time, put to politically dubious uses. Teju Cole, for his part, is a rooted cosmopolitan. ${ }^{5}$

\section{Notes}

1. In her Behold the Dreamers (2016), Imbolo Mbue offers another view of the uncertainties of some migrant lives, as she portrays how a youngish couple from her country Cameroon gets involved with New York. Their own situation may be complicated, not least by way of a somewhat dubiously legal immigrant status, but, as the husband finds employment as the personal chauffeur of a financial manager, they get an inside view of Manhattan affluence, with intricate family relationships, as well as a view from the backstage toward the collapse of Lehmann Brothers and the 2008 Wall Street crash. Here is a slice of the American scene as witnessed and commented on by African migrants, also with references to their own home country. (Mbue, for her part, lives in New York, and has two American academic degrees.)

2. For some evidence of Adichie's continued Nigerian rootedness and also double-sited family life (in Lagos and Baltimore), see an extended interview in the New Yorker (MacFarquhar 2018).

3. In a way, Teju Cole thus had a similar experience to that of Okey Ndibe: his first book published in the United States, with a story in large part played out on an American scene, turns out actually to be not the first written. Yet while Ndibe's Arrows of Rain was previously unpublished, Cole's Every Day Is for the Thief had already been around in Nigeria. 
4. Remarkably, there is a reference to Tranströmer in Every Day Is for the Thief (Cole 2014: 111) as well.

5. The notion of "rooted cosmopolitans" originates with another Afropolitan, the Ghanaian American philosopher Kwame Anthony Appiah (1996). It was entirely possible, Appiah argued, to find satisfaction in one's own country and its way of life, and yet appreciate the diversity assembled as others made their own choices. Appiah could speak with some personal authority: now a New York University professor, he was born and had grown up in what is now Ghana, with a West African father and a British mother (and a grandfather who had been a prominent minister in the British cabinet after World War II). It was especially his father, politically prominent at the time of the Ghanaian struggle for independence in the 1950s (but in opposition to Nkrumah), who had impressed on his children the fact that one could be at the same time a patriot and a citizen of the world.

\section{References}

Adichie, Chimamanda Ngozi. 2013. Americanah. London: Fourth Estate. . 2016. "The Arrangements: A Work of Fiction." New York Times Book Review, 3 July.

Appiah, Kwame Anthony. 1996. "Cosmopolitan Patriots.” In Joshua Cohen (ed.), For Love of Country. Boston: Beacon Press.

Cole, Teju. 2011. Open City. New York: Random House.

- 2014. Every Day Is for the Thief. New York: Random House. 2016. Known and Strange Things. New York: Random House.

MacFarquhar, Larissa. 2018. "Writing Home: Chimamanda Ngozi Adichie Comes to Terms with Global Fame." New Yorker, 4 and 11 June.

Manyika, Sarah Ladipo. 2016. Like a Mule Bringing Ice Cream to the Sun. Abuja: Cassava Republic Press.

Mbue, Imbolo. 2016. Behold the Dreamers. New York: Random House.

Ndibe, Okey. 2014. Foreign Gods, Inc. New York: Soho.

Osondu, E. C. 2010. Voice of America. New York: HarperCollins.

Pilling, David. 2016. Lunch with the FT: Chimamanda Ngozi Adichie. Financial Times, 30 June/1 July. 


\section{Sojourners from Black Britain}

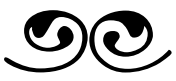

The 1990s under the Sani Abacha dictatorship became grim years. Wole Soyinka, realizing that his life was threatened-there would indeed be a number of political murders-escaped by canoe across the river to neighboring Benin. He then spent years in exile, connected to American universities, and in transcontinental diplomatic/oppositional shuttle traffic.

What the times were like in Nigeria can be glimpsed in Chigozie Obioma's well-received first novel The Fishermen (2015), about four young Igbo brothers in Akure, in Yorubaland-thus already somewhat diasporic. Early in the book, their father, a bank employee, reads his newspaper and exclaims, "If there is any justice in this world, Abacha should soon be mourned by his witch of a wife." Perhaps somewhat bordering on myth, the tale offers a scenery of civilian-soldier, NorthSouth tensions sometimes turning into violence, fragmented memories of war, expatriate preachers both mobile and resident, a difficult family life (the bank has just transferred the father to its Yola office, far to the northeast of the country, so he would have to become a long-distance commuter), and a local madman. The brothers get into trouble; finally, one of them may or may not make it to Canada, with a family friend who has already moved there.

Ken Saro-Wiwa, author of Sozaboy (see chapter 15), remained in Nigeria, and became a victim of the country's history and its geography. He belonged to the Ogoni, a small group of about half a million people in the Niger Delta. When the area was part of the Eastern Region, and then initially of Biafra, the Ogoni were ill-treated by the majority Igbo. When the federal order of Nigeria continued to split into more states, they were in Rivers State. The Ijaw people, dominant in that state, did not do much for the Ogoni either. Worst of all, they were in oil country, and the activities of the Shell Company were devastating for the Ogoni habitat. 
But Saro-Wiwa was not a passive victim-rather more a public intellectual-political activist, somewhat in the Wole Soyinka mold. We have seen that his academic career had taken him from Ibadan to Nsukka. Leaving that behind after Biafra's secession, he had become an administrator in a part of the Niger Delta back under Nigerian control. He went on to engage in various enterprises, as well as to write prolifically. Most of his writings were published in Nigeria, including Sozaboy. He produced satirical TV shows as well.

There was also, however, a political resistance involvement in the Movement for the Survival of the Ogoni People (MOSOP). This led to a certain internal conflict among the Ogoni, as there were older chiefs who were more accommodationist toward the sitting military regime. A number of these were attacked and killed at a meeting. Saro-Wiwa was not there, but as this was in the time of the Abacha dictatorship, and as Abacha had no doubt found Saro-Wiwa an inconvenient critic, he seized the opportunity to accuse him of planning the murder. And so, in November 1995, Saro-Wiwa was executed by hanging, together with eight other MOSOP leaders.

They were buried in Port Harcourt. Of Abacha's misdeeds, the killing of Saro-Wiwa was probably that which drew most international attention. ${ }^{1}$ For one thing, Nigeria was suspended from the Commonwealth for a period. (It does not seem, on the other hand, that the controversial work of the Shell Company in the Niger Delta was much affected.)

As it turns out, Saro-Wiwa's territorial linkages were as complex as the man. Like many Nigerians, he had a strong allegiance to his village of origin, out there in the Delta. His office, however, was in his house in Port Harcourt. And he sent his wife off to London, with his and her children, so that they could go to British schools. Yet these children had to come back to Nigeria during their long holidays so that they could imbibe the atmosphere of the village, even if SaroWiwa did not give them so much attention himself. The London-based wife eventually became less enthusiastic about that arrangement, and stopped coming along, partly because it turned out that Saro-Wiwa was now polygamous and also had children with another wife. On one occasion, however, he had taken three of his expatriated children on a long car journey, with a chauffeur, to see more of the mother country: Abuja, Jos, Kano.

By the time of the MOSOP events and their father's execution, the London Saro-Wiwas were utterly turned off as far as the fatherland was concerned. In 2005, however, some of them returned to have his remains reburied in the original home village; it had taken forensic 
tests to identify these after the first grave had been located. Several years later, one of them, his daughter Noo Saro-Wiwa, came back for a longer visit. After studying at British and American universities, she had become a journalist, and had been writing tourist guide materials on Africa and other parts of the world-so, finally, back to Nigeria. The result was the travelogue Looking for Transwonderland (2012). We might also think of it as creative nonfiction. ${ }^{2}$

Noo Saro-Wiwa's journey through Nigeria this time, stretching over four months, would to an extent retrace the route which, as a twelve-year-old, she had traveled with her father-going north, even to Maiduguri at the other end of the country.

Her portrait of Lagos, not a city of which she had much previous experience, is mostly similar to those offered over time by other observers: Cyprian Ekwensi, Chibundu Onuzo, Nnedi Okorafor, even that Swedish traveler Artur Lundkvist almost two-thirds of a century earlier. Chaotic traffic, dangerous "area boys," new skyscrapers crumbling, here and there a remaining low Afro-Brazilian building, a National Museum falling dark with a power failure, affluent Victoria Island with sophisticated shopping and cosmopolitan eateries. She could stay with Aunty Janice, an old friend of her mother's. Aunty Janice's husband had been in an early cohort of Nigerian diplomats, and the couple had been posted here and there in Europe. Drawing on that experience, Aunty Janice had established a fashion business in Lagos, and even now, decades later, she felt this was the place to be, eventful all the time: "It's crazy, but I like it."

Already in the metropolis, it struck Noo that Nigerians were the most fervently religious people she had ever come across. Evidently, Pentecostal brands of Christianity had struck the country particularly from the 1980s on, allowing a sort of escape from the hardships of everyday life. There were clearly American ingredients in this, even as it all blended into Nigerian thought and expression. In her time in Lagos, she heard "hairdressers singing their hallelujahs at salons; evangelical radio stations resounding in Internet cafés; bus passengers collectively breaking out into ovine choruses." Aunty Janice, who had crossed over into this from Catholicism, noted that this had turned Nigerians into the happiest people in the world, according to the ranking in a World Values Survey she had read.

In Lagos and elsewhere, Noo would do her local travel by okada motorcycle taxis or danfo minibuses. Renting a car did not appeal to her-she "lacked the curious mixture of patience and bloodymindedness required to negotiate Nigerian traffic successfully." Her long-distance travel was by road or air. Seeing a locomotive rattling 
along a rail somewhere, she was reminded of a train journey she had once made as a child, with two siblings, as part of her father's "educational sadism." A journey from Port Harcourt to Zaria (which would have passed through Kafanchan) in 1989 had taken half a week, and had really been "a no-no for respectable people of sane mind . . . a sweaty, shit-stained odyssey."

From Lagos she moved on to Ibadan and its surroundings, which turned out in large part to offer disappointments. The university, her father's alma mater, seemed no longer to offer any very satisfying academic experience. The old facilities were there, but severely overcrowded. As working conditions were poor, the university was the victim of an academic brain drain. Reputable scholars were off to the United States, South Africa, and elsewhere. Students found that assigned textbooks were unavailable or too expensive. Fraternities, which had once started out as debating clubs with high-minded social goals, had morphed, apparently from the 1980s Babangida years on, into sinister armed cults with odd rituals and outside connections, through which people in political power could threaten any oppositional elements. (We may remember from chapter 6 that in a story in The Thing around Your Neck, Chimamanda Ngozie Adichie describes a similar development on the University of Nigeria campus at Nsukka, although that was perhaps a bit more innocent.) Attractive women students might fly off to Abuja to become weekend consorts of politicians, and return to Ibadan with cash and new material assets. Yet there were still also ambitious students, planning to continue for higher degrees, whether in Nigeria or abroad, or dreaming of becoming writers.

On a Saturday morning, there was what might appear to be an improbable campus event: a dog show. The canine contestants were in large part Rottweilers, pit bull terriers, Alsatians.

The Transwonderland Amusement Park at Ibadan, from which Noo Saro-Wiwa derived the title for her book, she had found described in one of her rather out-of-date guidebooks as the closest thing Nigeria had to a Disney World. That turned out to be not very close. As a child, she had been an amusement park enthusiast. Now she found this one decrepit, with rides mostly standing still. As one attendant persuaded her to try the Ferris wheel, she found she was alone up there, watched by a small crowd from below. She bought tickets for some boys to join her on the Dragon roller coaster ride, and they screamed together as the rusting carriages plunged precariously down the old tracks.

From Ibadan she also made an excursion to Osogbo to see the sacred shrine that, particularly through the efforts of Susanne Wenger (see chapter 6), had become recognized as a UNESCO World Heritage Site. 
Again, Noo found the site in decay, although a number of sculptures still showed Wenger's distinctive style; unkempt and fading, they could fit into the color of the surrounding forest. In old age, Wenger had been disgusted by what was happening to her creation. The authorities had sold off parts of the sacred grove to property developers. At festivals, soft drink sellers proclaimed that gods would bless customers who used their beverage brands to pour libation.

Next on the itinerary was Abuja. The visitor noted that local cars had number plates with the motto "Centre of Unity"-yes, she reflected, the new capital seemed to have united Nigerians in the view that it was the dullest place on earth. Traffic-free highways passed shopping malls and glass-covered buildings gleaming with passé futurism. Yet Fulani herdsmen could still move their cattle along the side of the roads.

In Abuja, Noo Saro-Wiwa stayed with her brother. Although he had never used anything but public transportation in London as they grew up, and had been an expert on getting from anywhere to anywhere by bus or Underground, he now sat in the back seat behind his chauffeur-he had become an oga, a bigman. It turns out that in a spirit of reconciliation with the civilian government, Ken Saro-Wiwa's son had been offered a job as a senior civil servant, and had accepted it. With him and his circle, then, Noo could discuss corruption and nepotism.

On to Kano, where one senses that there is a cultural distance between Noo and the surrounding Hausa society of the Deep North. There were fewer English-speakers than in the South, and Noo did not dress like local women. She encountered one Black American woman who had already converted to Islam back at home in Miami, and then migrated to Nigeria to marry. This informant argued that Hausa women could actually be more powerful than they might appear. From behind the scenes they could run significant businesses. On the whole, it seems that in Kano, Noo was often in the company of expatriates and descendants of expatriates. She went to see the durbar parade at the end of Ramadan, a quasi-traditional festivity, although actually a colonial-era invention, again with numerous dressed-up expatriates in the audience. And then it seems she was most at ease back in the hotel room, watching her favorite Nollywood series on television.

It appears that Maiduguri was the low point of her journey: a dusty hotel room, unreliable electricity supply, a particularly dispiriting market place, unworkable ATM machines when she needed some more cash. Not much, it seems, that would draw her particular curiositybut obviously Boko Haram was not around yet. After that, a visit to the mountain kingdom of the Sukur people was a more comforting experience: the Sukur were Hausa-speaking Christians, probably one- 
time migrants from Cameroon, and the king was a pleasant, relaxed eighty-seven-year-old, nowadays without much power.

Jos had been Noo's favorite Nigerian city on that childhood journey with her father: an old tin-mining town on a high plateau with a cool climate by Nigerian standards. But it had obviously grown a lot since then. Noo hurried to the local museum, which was unusual in showing the typical housing of Nigerian regions in an open-air setting: Igbo, Yoruba, Hausa, Tiv, and Nupe, and a replica of Zaria's Friday Mosque. The whole thing, however, was in need of repair. The silver-haired caretaker said there was a lack of funding. Noo remembered, too, the old museum restaurant, where she had once had the best fried plantain she had ever eaten. Now it was replaced by a Chinese eatery, where she could get sweet-and-sour chicken.

We may remember from chapter 17 that Morayo Da Silva, the aging San Francisco expatriate whom we encountered in Sarah Ladipo Manyika's Like a Mule Bringing Ice Cream to the Sun, had spent some of her childhood in Jos. And we have seen in earlier chapters, tooas, for example, in examining Cyprian Ekwensi's Biafra War novel Divided We Stand-Jos has drawn its population from near and far in Nigeria. ${ }^{3}$ Among the people coming in from nearby on the plateau, a fair number were Birom people, still keeping some distance from the world religions when Tai Solarin visited them fifty years earlier. Now Noo Saro-Wiwa found them in the Christian corner-and thus in an adversary relationship to those Muslim Hausa and Fulani whose numbers in Jos were increasing, leading to violent conflict.

A stop in Bauchi (a city we may remember from Ibrahim Tahir's The Last Imam, in chapter 13), not so far from Jos, offered a certain amount of pleasure. There was the tomb of Abubakar Tafawa Balewa, Nigeria's first prime minister, murdered in the first military coup in 1966. Tafawa Balewa was a notably uncorrupt politician, and his grave was simple. But in the company of a student group, Noo could watch a videocassette tape of Tafawa Balewa's first speech to the newly independent country. On exhibit was also the small Sony TV set he had received as a personal gift from Queen Elizabeth.

It irritated Noo Saro-Wiwa that so many streets and squares in Nigerian cities were named after rather ill-reputed past politicians, including military dictators-Babangida Square, Sani Abacha Road. But when she pointed this out, it seemed that this was not so much a matter of continued reverence. Rather, these sites had been named when the potentates in question were still alive and strong, and after their death they remained there, often run down, as another indication of Nigerian unconcern with the obsolete. 
In the early 1960s, John Pepper Clark's new American acquaintances may have assumed that back at home, he may have mingled with wild animals as part of his Nigerian everyday life, and were surprised that he wanted to go to the zoo-see chapter 16. Noo Saro-Wiwa, for her part, wanted to make some wildlife excursions part of her Nigerian experience, but it was not so easy. In the North, she had taken a side trip to the Yankari Game Reserve, but apart from some trivial monkeys, most of the animals just failed to show up. Fortunately, there was a rainforest wildlife reserve in the Southeast where she could meet with both gorillas and chimpanzees. But on the whole, it was clear that Nigeria had not done much to safeguard the habitats of what had once been a more striking fauna. Up in the northeast, not so far from Maiduguri, she was told, there had once been giraffes.

Now, however, Noo Saro-Wiwa could head south. Calabar, in the southeast on the coast, was perhaps her favorite Nigerian city-she might have preferred it, rather than Abuja, as the national capital. For a period, at least, it stood out as a model of good governance. The streets were clean. The museum, in an old colonial-era building, told the story of how the slave trade had transformed the local Efik people "from fishermen and farmers into Anglophile traders." It was a museum that compared very favorably with the slave trade museum she had already visited in Badagry, west of Lagos. Rather accidentally, too, she was invited to the wedding of a friend of a new local friend whom she had met while standing in admiration of her house. It was a lively affair, with a band playing highlife music, an emcee announcing the arrivals of chiefs and other notables, and the groom and his entourage shuffling in accompanied by drumbeats. And then the food was served, jollof rice and goat meat.

Yet not even Calabar could be all wonderful or all that it claimed to be. It was a bit odd, for one thing, that it served as a comfortable asylum for the Liberian warlord and ex-president Charles Taylor and his family (until he was extradited and sentenced for a variety of war crimes through internationally organized court proceedings). And a shopping mall on the outskirts of the town, once even shown on CNN, turned out to be more or less a mirage.

From here on, Noo Saro-Wiwa did not exactly move on a straight path. Benin, on the other side of the River Niger and a little further on yet, was a must for somebody interested in Nigerian tourism potential, even as it was evidently a place where she had no really close contacts. She offers her readers a short sketch of the historical glory of the Benin Kingdom (not to be confused, of course, with the current Republic of Benin, the country to which Wole Soyinka had to escape by canoe), 
and hints at current conflicts at the court of the traditional ruler, the oba-conflicts between old-style aristocracy and recent plutocracy.

Later, eastward again along the coast, to Port Harcourt. Here her stay was not so relaxed. This was her old home town, and she could stay in the house where she grew up, as it was still in the family. But she was alone there now, and she could not venture out in the streets by herself, as everybody warned her that the environment was too dangerous. Port Harcourt had become the turf of competing organized crime gangs, with political connections, doing business in kidnappings, blackmail, and stolen oil from the Delta.

Only a little distance away, however, there was Bane, the ancestral village of the Saro-Wiwas, where as a boy her father had started his business career (earning money to continue his schooling) by selling palm wine in the village streets. And it was also where he was now buried. Younger people were leaving the village, migrating to jobs in cities. Yet here was indeed the one place on earth that felt like hers: her genes alone, she felt, granted her an undisputed claim to the land.

Finally, Lagos again, before she would return to London. She enjoyed the comforts of Ikoyi and Victoria Island. She had some slight quarreling, too, with Aunty Janice about what role religion could play in future Nigerian development. The mostly secular Noo argued for strong and honest leaders, and a people coming together to support them, not just through prayer. In her future scenario, the country could also arrive in a postpetroleum era, "growing crops, maintaining extended family networks, worshipping deities." A small part of her, she confessed, momentarily entertained the idea of moving back to try and help develop Nigerian tourism-but then the next, more durable, thought was that it would most likely turn out to be a quagmire, and she was grateful to her father for insisting on raising children who would be able to choose where to live.

In one way, nonetheless, she was inclined to agree with Aunty Janice. About Lagos, she writes, "I realized that Lagos is in fact one of Nigeria's greatest success stories. It's an achievement when 15 million people across 250 ethnic groups can live together relatively harmoniously in an unstructured, dirty metropolis seemingly governed by no one." A nice place to visit, it seems after all, even if she did not want to live there.

Other observers have had similarly strong, but mixed, feelings: love-hate relationships with the country, variously distributed over experiences and places. Noo Saro-Wiwa's reporting journey across Nigeria actually had a predecessor some twenty-five years earlier, with a writer whose background was in some ways similar to hers and in other ways different. I met Adewale Maja-Pearce in 1992, at a 
UNESCO-related conference held in a small Swedish town of medieval origins, seen as suitable for such events. He was not too happy about the conference organization, and made that clear, but he and I got along well, and I was pleased when soon afterward he sent me two books of his, both then fairly recently published: In My Father's Country: A Nigerian Journey (1987) and How Many Miles to Babylon? (1990).

Maja-Pearce's family name did not come with the fame of Noo Saro-Wiwa's, but it was certainly rooted in old Lagosian respectability. His paternal grandfather was born in 1878 and, mission-educated, had become a minister in the Methodist Church-also a justice of the peace, a fellow of the Royal Geographical Society, and an official Member of the British Empire. But it was his wife, the grandmother, who had been a highly successful trader and who could therefore fund the children's training overseas. Not all of them did so well. One son failed in his studies and eventually became a taxi driver in New York. But the son who became Maja-Pearce's father studied medicine in Britain, and, while a student, he met and married Maja-Pearce's Scottish mother. On qualifying as a surgeon, he took her back to Lagos with their London-born young son Adewale.

That turned out not to be a happy marriage. They lived in Ikoyi, the upscale suburban island, still mostly racially segregated. ${ }^{4}$ From his window, the boy Adewale could observe their expatriate neighbors' sedate garden parties, to which his parents were not invited. The parties that his father threw, on the other hand, were noisy, rambunctious affairs with a hired band: "men and women, dressed to kill, drank, shouted and danced all night." Those expatriate neighbors were invited but never showed up.

Having a British wife may have been a sort of trophy for a successful been-to (a term Maja-Pearce does not use in his book), but at the same time it was a union wasted in local Nigerian circles. So Adewale's father spent an increasing amount of time with a new girlfriend and had a child with her. There were quarrels at home, and eventually separation. Mother and son returned to London. Father and grandfather-the surgeon and the Methodist minister-also came into serious conflict, as the latter disapproved of his son's lifestyle, sided rather more with his British daughter-in-law, and was later unhappy about the rumor that in the son's new household, after a remarriage, there were apparently juju practices.

By then, however, Adewale had had his early education in primary schools with European teachers and mostly expatriate children, becoming, he later wrote, "a proper little colonial with a faultless English accent.” He never learned Yoruba, his father's first language. 
Back in England, in time, he went for higher education and took a master's degree at the School of Oriental and African Studies, University of London.

He had had one earlier short visit to Nigeria after his father's death, and then came up with the idea of a second trip to write a book. It became a lively journey, in terms of sights and sounds, experiences, and interactions. As far as military regimes were concerned, Maja-Pearce happened to be in the country when General Buhari was overthrown by General Babangida, so it was not yet Abacha time. If Americans had found John Pepper Clark a tough visiting interlocutor in the 1960s, Nigerians may have found a counterpart in Adewale Maja-Pearce in the 1980s.

His agreement with his publisher allowed for a two-month journey through Nigeria-half as much as Noo Saro-Wiwa's, so this had to be rather hurried. And this would be by car only, share taxis in the regular Nigerian way. No flights, and "one might as well forget the trains"someone he talked to had made the journey by rail from one end of the country to the other, and "he made it sound as close to purgatory as one is likely to experience in this lifetime." (This was about the same time as Noo Saro-Wiwa had her childhood railway journey.)

So Maja-Pearce hit the road. This would involve changing cars here and there, as there would not always be direct cars heading for the cities he wanted to go to, and that could involve some waiting time. Moreover, the rides would not always be so comfortable-for one thing, they could feel downright dangerous. The Peugeot 504s, which were the most commonly used cars, were referred to as "flying coffins." On one of his first longer road journeys, from Ilorin in northern Yorubaland to Kaduna, seven hours mostly in the dark, the driver slammed his foot on the accelerator as he left the city limits behind, and "the speedometer did a complete circle"; he also kept chewing kola nut to stay awake. $\mathrm{He}$ would overtake trucks uphill on a bend, and it would seem like there were millimeters between the truck and a meeting vehicle.

Yet Maja-Pearce survived all that, and saw much of Nigeria, although much of it only hurriedly. Kaduna, Zaria, Kano, Lokoja, Abuja, Jos, Yola, Maiduguri ... . The person he had planned to see in Maiduguri was away, so he hurried back to the motor park for the next stop on his itinerary. He had really gone there only to be able to say that he had been there. (Maiduguri would be the Timbuktu of Nigeria travelersthe ultimate faraway city-if not the end of the world, then at least as far from Lagos as you could get.)

Lokoja in the 1980s turned out to be a glorified village at a filthy, sluggish river; nowhere was that hotel balcony where he had imagined 
enjoying a leisurely meal. So again, back to the motor park he went, to find a seat in a car for Benin. And yes, it turned out he would have to change in a town in between.

Interestingly, while on his journey through the North, the son of a Yoruba doctor developed a sort of preference for this part of Nigeriarather unlike Noo Saro-Wiwa. In a way, he argued, it was not only more peaceful, but also more civilized. Islam brought a greater sense of continuity with the past. Northerners came across as more self-reliant than their Southern counterparts. Missionary activity might have given the latter a head start in twentieth-century life, but it had also left them with "a species of schizophrenia which goes a long way to account for the levels of brutality that is a dominant feature of life in the south."

Nonetheless, it was mostly in the South that Maja-Pearce could pursue one of his main interests: in Nigerian writing. Here, certainly, he could again be very opinionated. Mostly he would not refer to any of the better-known Nigerian fiction writers by name, but discussed styles, genres, and recurrent weaknesses.

Again, there is a fair amount of crime writing, but not so much of higher quality (see, too, chapter 9). Maja-Pearce chose one example, from Fourth Dimension Publishers, Enugu. He enjoyed it, getting through it in a single sitting. But he found it garishly violent, very likely inspired by the hardboiled writing style of Americans such as James Hadley Chase, whose books were widely available in small local bookshops, as well as on the shelves of bigger-city chain supermarkets.

The Onitsha chapbooks got some passing, slightly ironic mention, as the traveling commentator made his quick visit to the market. There was a taxi waiting to go to Lagos.

In Ibadan, he had some unpleasant experience of poor service at the university library, when he tried in vain to look up some references to one well-known early Nigerian writer. He also ran into an old acquaintance, someone who had been a prefect and thus a respected senior pupil in the Lagos school where Maja-Pearce had gone as a child, and who was now a doctor and an aspiring novelist. But Maja-Pearce was again unimpressed with the results. The problem, in his view, was that someone like this had too little and too narrow knowledge of that language in which he felt he must write; he could not handle it with the familiarity and ease of a native speaker of English. Yet with London as the center of the literary world, that was the language he had to work in. And he would prefer a bad review in the Times Literary Supplement to a favorable review in the Lagos Daily Times.

At the University of Calabar, on the other hand, there was Uche, a poet and playwright preferring to write in Igbo to reach a local 
audience. Maja-Pearce liked to hear this-but was told there were problems. Uche would have liked to return to his village, but he could not support his family there. Furthermore, he had spent four years in London writing a dissertation. If after such a venture he came back to the village, his neighbors there could only conclude that he was a failure.

What, then, could one do with Nigeria's languages, hundreds of them? Maja-Pearce arrived at the opinion that they must have different futures. Hausa, Igbo, and Yoruba had large numbers of speakers, and there could be a strong literature in each of them. A half-dozen other languages might survive in more marginal existences. A great many others, with very few speakers, hardly had any such prospects. Conservative, backward, even reactionary-they were probably best left to die in peace.

Uche, in Calabar, also had a colleague who dropped by, and whom Maja-Pearce knew by reputation as an "experimental novelist." $\mathrm{He}$ brought a copy of his latest book, and the visitor had a quick look at the first few sentences. There was nothing that would change his mind: "When I hear the word experimental applied to a writer I run a mile."

Other kinds of issues concerned him as well. Here and there in the book, questions are raised about the situation of women in Nigerian society: on the one hand, some of them, past and present, have been powerful and respected; on the other hand, they seemed to this visitor to be often ill-treated, even suffering minor or major violence in their marriages. Perhaps his parents' unhappy relationship played a part in his thinking here.

At another level, and relating to one particular national event, he was critical of the treatment of Africa in international news reporting. As the Buhari-to-Babangida regime change had occurred while he was in Nigeria, he had offered one British newspaper to do an article on it. It turned out it had sent out one of its own journalists from London to report on it quickly and return. At some later point, he had run into this newsman, who had told him that with African news stories, he would hardly ever need more than twenty-four hours in the country to know what was going on. Often he did not even need to leave the airport. For Maja-Pearce, this was the attitude that so often resulted in the misrepresentation of African realities. You could not treat the United States or Poland like that. "But Africa is different; Africa is simple."

As his return to Britain after these two months approached, Adewale Maja-Pearce became increasingly depressed. On the one hand, he had become fascinated by Lagos. He could now understand what people meant when, like Noo Saro-Wiwa's Aunty Janice, they said they could 
live nowhere else: "There is an energy and a vitality about Lagos which challenges the visitor. Everybody is on the make; everybody is hustling twenty-four hours a day." On the other hand, his own relationship to Nigeria was still as ambiguous as when he started out on his journey. Nothing had really been resolved. But he was also beginning to realize that nothing could be resolved.

Yet then there was that other book, a few years later: How Many Miles to Babylon? It is a multifaceted long essay on life in his mother's country-or, rather, what it had turned into for him. It is a more introspective book than his Nigerian reportage, about his self, in terms of race and, more importantly, culture. Here is also a harsh portrait of 1970s multiracial Britain and the young Maja-Pearce's interactions with people who were only half-heartedly turning into Black Britishof Caribbean and African background, living partly in some nostalgic fantasyland, partly perhaps in a world of petty crime-outsiders, "wogs," "jungle bunnies" in some arrogant native parlance. ${ }^{5}$ MajaPearce has periods in Canada and in Ireland as well, and imagines going to live in yet other parts of the world. Ireland reminds him of Nigeria: "the same extended family arrangement where everybody was your cousin, no matter how distant, and there was the same place of the religious as an integral part of everyday life."

He had in fact planned to do this book rather more in the style of In My Father's Country, an account of a journey through Britain. That, however, did not work out so well. He did not find so many outgoing, talkative strangers along the way, rushing to make his acquaintanceamong the British, "the notion of individual space is firmly rooted in the national psyche." As a sort of pilgrimage, he went to the cemetery in a Scottish Highlands village, where he found the headstone of his maternal grandparents, a couple who had cared for him when as a child he had come back to Britain. As his grandfather had once in his youth walked away from that village, away from the hardships that again and again became the fate of Celtic people at the outskirts of the United Kingdom, Maja-Pearce reflected, he had begun the moves across borders, between continents, that would characterize the lives of so many of his descendants.

And evidently the Nigerian experience accounted for in In My Father's Country was not enough for Adewale Maja-Pearce. The year after the publication of How Many Miles to Babylon?, there would be that slim volume of essays named Who's Afraid of Wole Soyinka? By now he was Africa editor for the journal Index on Censorship, and series editor for the Heinemann African Writers Series, publishing so many of a generation of African authors. The title essay of Who's Afraid of Wole 
Soyinka? has its point of departure in Soyinka's politically provocative speech at a Lagos event celebrating his Nobel Prize, where in front of a rear-admiral who was second-in-command of the ruling junta, he had told the military to get out of politics, in Nigeria and elsewhere in Africa. The point was that those who were wrongly in power, and who misused it, had reason to be afraid of free speech, from Soyinka and others using it effectively.

In his writings for Index on Censorship, Maja-Pearce reported on African affairs generally, but with a center of gravity in Nigeria. And he would indeed return to Lagos for extended periods, commenting on Nigerian affairs for the New York Times, the London Review of Books, and the British journal Prospect. He also published locally, even to the extent of running a small publishing house. A recent Wikipedia entry tells us that he lives in Surulere, an inland Lagos neighborhood, in a property passed down in the family. Not a return to Ikoyi, but perhaps as close to a sense of home as someone like Adewale Maja-Pearce could well think of. ${ }^{6}$

\section{Notes}

1. A wide-ranging book edited by Abdul Rasheed Na'Allah, Ogoni's Agonies (1998) describes the African and international response to the killing of Ken Saro-Wiwa. Wole Soyinka has an extensive account of his efforts to mobilize world opinion in You Must Set Forth at Dawn (2006: 419-427; see also Quayson 2003: 56-75).

2. British-based Afropolitan writers have been doing multisited fiction as well; see Popoola 2017. Popoola holds a PhD in creative writing from the University of East London and publishes with Cassava Republic Press.

3. Leonard Plotnicov's Strangers to the City (1967) offers an anthropological portrait of ethnic diversity in Jos in the early 1960s.

4. On Ikoyi, see also Nina Darnton's view of it in chapter 9, and Chinua Achebe's and Cyprian Ekwensi's, as cited in note 3 in that chapter.

5. For another brief account of late twentieth-century Black London by a British-Nigerian (who refers to Adewale Maja-Pearce as well as Biyi Bandele-see chapter 14), see Gbadamosi 1994.

6. That house in Surulere, however, has been the topic of yet another small book (Maja-Pearce 2018), published locally in Lagos. When Maja-Pearce finally established his ownership rights to it, the process of getting its tenants to move out turned out to be complicated. 


\section{References}

Gbadamosi, Gabriel. 1994. “The Road to Brixton Market.” In Gabriel Gbadamosi and Ato Quayson, Redrawing the Map: Two African Journeys. Cambridge: Prickly Pear Press.

Maja-Pearce, Adewale. 1987. In My Father's Country: A Nigerian Journey. London: Heinemann.

-1990. How Many Miles to Babylon? London: Heinemann. 1991. Who is Afraid of Wole Soyinka? London: Heinemann. 2018. The House My Father Built. Lagos: Kachifo.

Na'Allah, Abdul Rasheed. 1998. Ogoni's Agonies: Ken Saro-Wiwa and the Crisis in Nigeria. Trenton, NJ: Africa World Press.

Obioma, Chigozie. 2015. The Fishermen. London: Pushkin Press.

Plotnicov, Leonard. 1967. Strangers to the City. Pittsburgh: University of Pittsburgh Press.

Popoola, Olumide. 2017. When We Speak of Nothing. Abuja: Cassava Republic Press.

Quayson, Ato. 2003. Calibrations. Minneapolis: University of Minnesota Press. Saro-Wiwa, Ken. 1985. Sozaboy. Port Harcourt: Saros International.

Saro-Wiwa, Noo. 2012. Looking for Transwonderland: Travels in Nigeria. London: Granta.

Soyinka, Wole. 2006. You Must Set Forth at Dawn. New York: Random House. 


\section{Oyotunji Village, South Carolina Reverse Afropolitanism}

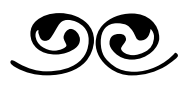

The most conspicuous, and continuous, historical connection of Nigeria to the Americas has been that to Brazil. We encountered it first in chapter 2, with "Mariana's story," as drawn from Antonio Olinto's novel The Water House. We were reminded of it in chapter 11, with Wole Soyinka's escapade to Salvador, old metropolis of Plantation Brazil, to retrieve the ori olokun sculpture to the motherland. And Afro-Brazilian family names show up here and there in Nigerian fiction: in Cyprian Ekwensi's Lagos, as well as in Sarah Ladipo Manyika's San Francisco. Teju Cole refers to the Brazilian connection as well.

But the Afro-Atlantic extended further northward, with or without direct Nigerian linkages. Here and there in the New World, people of African background established their own communities and adapted to new circumstances. Some of the settlements were formed by escapees from plantation slavery. The settlements in Brazil became known as quilombos, sometimes quite sizeable. The overall term for the escapees, in whatever territory they were, became "Maroons." ${ }^{1}$ In Surinam, long-term Dutch colony, the world outside referred to them as "Bush Negroes," while among themselves they were divided into sizeable collectivities such as the Djuka and the Saramacca. While Maroon settlements were often founded in inaccessible, inland, perhaps mountainous areas where the formerly enslaved could not be easily recaptured, there were places and times where they established some sort of ambiguous coexistence with plantations and local markets. They could be frontier communities of many kinds: sometimes merging with local Amerindian groupings; at other times possibly including outlaws of mixed origins. Their relationships to African ethnic heritages could vary. In Salvador, we have seen, there was a noticeable connection to what would become recognized as Yoruba. In Cuba, too, the Afro- 
Catholic beliefs and practices referred to as Santeria showed traces of a similar past. Among the Maroons in the hills of Jamaica, there was a stronger ingredient from the Akan cultural groupings of what is now Ghana. In other areas, the mixture of people brought ashore by the slave trade made it more difficult to identify African ethnic linkages. In the Caribbean, too, while the French Revolution and the upheavals that followed were perhaps distracting the European imperial power, the French part of the island of Hispaniola was the site of another revolution, establishing Haiti as the first Black nation in the New World, certainly again with a notable African cultural heritage. ${ }^{2}$ The revolutionary hero was Toussaint L'Ouverture; when Morayo da Silva, in Sarah Ladipo Manyika's Like a Mule Bringing Ice Cream to the Sun, meets a Caribbean cook named Toussaint in San Francisco, we can perhaps guess whom he had been named after.

Then in the twentieth century, well after the end of slavery, African Americans in the different lands of the New World engaged with African as well as European linkages in various ways. Jamaicans, by now in large part urban proletarians, could reinvent their past by identifying with what had been there forever as an independent African nation, in distant Ethiopia-from where it was really certain that hardly any of their ancestors had come-and become Rastafarians. (Ras Tafari later became better known as Emperor Haile Selassie.) When Surinam was to become independent, its inhabitants could choose between becoming Surinamese and becoming Dutch citizens. So a considerable number moved across the Atlantic to establish themselves in the suburbs of Amsterdam and elsewhere. ${ }^{3}$ (These migrants were more likely already coastal, metropolitan-oriented urbanites, rather than those inland former "Bush Negroes.") From the islands of the Caribbean, we have already seen, not so few would head for the United States, where Nigerian migrants such as Chimamanda Ngozi Adichie would keep encountering them.

And then especially as African countries were emerging out of colonialism, African Americans in the United States were also getting more involved with Africa, past and present, in a rich landscape of the imagination and of fact-finding. In the academic discipline of history and in other cultural studies, "Afrocentrism" emerged as a new research genre. In the 1970s, the engagement of African Americans with West African motherlands was stimulated by the author Alex Haley's basically semifictional account, in the book Roots (1976), of how he traveled to West Africa and up the Gambia River to find the home of his ancestor Kunta Kinte, who had disappeared from there to be carried in the slave trade to North America. Roots, of course, 
achieved an even stronger grip on the popular imagination in Black America when it was turned into a TV series as well. (Before Roots, Haley had been known primarily as ghostwriter for The Autobiography of Malcolm X.)

Let us focus now, and finally, on two Black communities in the United States with their particular, and very different, places in an Afropolitan world. Come along to the southeastern United States, from northern Florida through Georgia and South Carolina, into North Carolina. It is an area rich in African American history-a long way from Salvador, Brazil, although somehow not so far. ${ }^{4}$

For one thing, there is an area that may in a way seem reminiscent of those remote lands where Maroons took refuge elsewhere-and yet it is different. It is an area where the traces of an African heritage are noticeable and varied, but instead of being in the inaccessible inland mountains, it is in the similarly hard-to-reach coastal wetlands. This is the home of the people known as Gullah, or Geechee. In the era of slavery, there were rice plantations here. But the climate was unhealthy, so the British or British-descendant owners stayed away much of the time. It did not help either that the slaves brought germs from Africa to which they themselves had some resistance, but to which people of European stock were vulnerable. (We may be reminded of "the white man's grave" on the other side of the Atlantic, at more or less the same time.) Consequently, the slaves were left a great deal to their own devices. Then, it seems, when the American War of Independence broke out, many of the planters departed for good, as they were British loyalists. So here you had not runaway slaves, but runaway slave owners.

Who were those Gullah, or Geechee? Ideas about the origin of the name "Gullah" seem to be guesswork. Does it derive from "Angola," rather far south on the West African coast? Or does it come from Gola, an ethnic group in what is now Liberia? Or Dyula, a major grouping with a large West African home territory? It is difficult to say, because here the elements of the African heritage cannot so easily be identified with any particular part of Africa, as once affected by the slave trade. Many of the slaves who ended up in North America did not come straight from the African continent, but by way of the Caribbean islands, where people of different origins were mixed together. It is easier to say where the name "Geechee" came from-apparently from the nearby Ogeechee River.

Along the coast, and on the islands outside it, the Gullah have for an extended period lived on the outskirts of American society and maintained a distinctive culture of their own. Yet again, that 
distinctiveness may not have been altogether a consequence of remoteness: like those Maroons elsewhere, they may have been in touch with relative neighbors, where their special skills may have been a marketplace asset in a division of knowledge, and where some other shared ideas and expressions may simply have served them in maintaining a group identity. Those who have migrated into the wider society have tended to become assimilated into Black America more generally, rather than conspicuously sticking to a distinctive identity of their own. But more recently there has been a conscious cultural revitalization, affirming local rights-in the face of the fact that EuroAmericans have been coming back to those shores, to retirement communities with yacht harbors and golf courses. So now there is a Gullah/Geechee Cultural Heritage Corridor, officially recognized as a National Heritage Area, with a number of dispersed sites of different kinds. And on 2 July 2000, the Gullah/Geechee nation was proclaimed, with a head of state/queen mother/official spokesperson. ${ }^{5}$

The Gullah cultural heritage-food, textiles, basketry, music, folklore, language- - has allowed the growth of public events, tourist sites, and academic scholarship. But the pioneer in the latter was Lorenzo Dow Turner, who from the early 1930s devoted himself to studying the Gullah language. ${ }^{6}$

Turner was the descendant of an educated Black family, although growing up under some economic hardship due to the separation of his parents. His father, a teacher in a school he ran himself, and a man with a temper, got into a fight with a white man who had insulted him, and having hurt that man, he hurriedly fled from the home in North Carolina, never to reunite with his family again. Lorenzo's mother took what remained of the family north, and after finishing high school in Washington, DC, her son entered Howard University there-a leading institution among what would later be classified as Historically Black Colleges and Universities, or HBCUs for short. (These were the schools where early African students such as Nnamdi Azikiwe would have most of their American academic experience.) He would stay there long as a faculty member, but, juggling income sources and scholarly ambitions, he somehow also achieved higher degrees at two institutions that were early in accepting the occasional Black student: he got a master's degree at Harvard, and a doctorate at the University of Chicago.

It was when he was teaching summer school at a small Black college in South Carolina that the idea of doing linguistic research among the nearby Gullah dawned on him. A modest grant allowed him to begin on the project in the summer of 1932. Gullah English, he discovered, was not just "bad English," the outcome of a lack of education, as people 
had tended to think. It was a Creole dialect, with African ingredients of many kinds.

Turner would pursue this research interest in Africanisms in Gullah, in comparable forms elsewhere in the New World, and in African languages, over a very long time and in many ways. In the late 1930s, he went to London for a year at the School of Oriental Studies (not yet "of Oriental and African Studies"-that would come later), the best place to learn more about African languages. Early in the 1940s, in contact with various other American scholars in different disciplines, who had begun to develop parallel interests, he went to Brazil for another year. Perhaps inevitably, he came to spend much of it in Bahia.

While back in the United States, Turner's career continued to take him mostly through the HBCUs, and the segregation of scholarship also meant that his academic reputation tended to depend on the mediation of colleagues in the white mainstream. Yet finally, in 1949, seventeen years after the beginning of his Gullah research, his book Africanisms in the Gullah Dialect was published by a reputable university press. The immediate reception in the dominant circle of white American linguists was not all favorable, but with time the book became a classic. So here again, it can perhaps be suggested, in the creolizing encounter between African language and English, we may be reminded of both Amos Tutuola ("young English" according to Dylan Thomas) and Ken Saro-Wiwa ("rotten English").

By this time, Lorenzo Turner had also gained sufficient recognition to be funded (by the recently established Fulbright program) for spending time in West Africa, especially Nigeria. He arrived at Lagos harbor by an Elder Dempster ship in early 1951. It turned out to be another long, physically demanding as well as intellectually rewarding sojourn. Since after his Brazilian experience he was particularly interested in Yoruba language and culture, Ibadan was a natural place to stay, although he took a side trip to Onitsha as well. As the permanent campus of the recently created university was not ready yet, and he could not find a place to stay at the temporary campus, he rented an off-campus chalet. His diary refers to three trips to Abeokuta, with "the Beiers." One of them was Ulli Beier; Mrs. Beier was Susanne Wenger. And so we are back to chapter $6 .^{7}$

But let us return now to South Carolina, to a place just a little north of the old harbor town of Beaufort, on a forest lane off Highway 21, close to that Gullah/Geechee Cultural Heritage Corridor but not part of it. A roadside sign announces that "You Are Now Leaving the United States of America." And then another sign says "African Village Oyotunji, as Seen on TV. South Carolina: Smiling Faces, Beautiful Places." 
The story of Oyotunji Village has been told in a (richly theoryladen) ethnography by Kamari Maxine Clarke (2004), Afro-Canadian anthropologist, who did extensive, multi-sited field research there and in the network of places to which, in one way or other, it connects. ${ }^{8}$ It is a story beginning with Walter Eugene King, born in Detroit in 1928, leaving his early Baptist faith. He had taken an interest in African culture already as a teenager, and gone to Haiti with the Katherine Dunham Dance Company_Dunham was also trained as an anthropologist. $\mathrm{He}$ went to Cuba as well, and back in the United States, he moved to New York, where, toward the end of the 1950s, he initially joined a local Afro-Cuban Santeria cult, brought to the United States by migrants from Cuba. After some time, however, King became dissatisfied with the Afro-Catholic tendencies of his adopted religion, and struck out in search of something more authentically African. He read up on what he could find of written historical and anthropological sources on Yoruba religion, combined his new insights with the Black nationalism growing around him, started a Yoruba temple, and renamed himself Adefunmi.

In 1970, with five families accompanying him, Adefunmi moved from New York to South Carolina. After some complications, they managed to buy ten acres of uninhabited land, on which Oyotunji Village was built. Oyotunji means "Oyo rises again" —so the town's name refers to the old city in northern Yorubaland. Adefunmi was crowned as $\mathrm{Oba}$, the Yoruba kingship title. With time, the community grew, as more newcomers became villagers. A wider organized constituency of sympathizers was also cultivated. There was an active branch in the Bronx, New York. Moreover, the idea was to make Oyotunji Village an attractive site for visitors, in times when more Black Americans began taking an interest in an African heritage. Thus an element of cultural commoditization was also involved.

The villagers, then, were reinvented Yoruba, born-again Yoruba. But they did not want their understanding of the ideas and practices of their adopted culture to rely entirely on the writings of outsiders, even white American academics, so they sought contacts in Nigeria and began traveling there. In other words, here was a reverse Afropolitanism: Americans reaching out from their North American periphery to an attractive African center.

Yet the overseas pilgrimage to Yorubaland could be a mixed experience. Indeed, they would find chiefs and priests willing to meet them and engage with them. However, it seems that ordinary locals were not so inclined to see the Oyotunji visitors as real Yoruba; they were referred to as oyinbo (which usually means foreigners, white people). On the other hand, the visitors were somewhat unimpressed 
by the Africanness of their Nigerian contemporaries. Many of them did not dress right; their life styles were in various ways culturally contaminated; and by now they seemed more or less evenly divided in their religious enthusiasms between Christianity and Islam, in longestablished or new forms, with fewer adherents to a pure old-time religion. Returning home to South Carolina, Oyotunji representatives concluded that it was now up to the African Americans to safeguard the purity of Yoruba religion and culture. (Perhaps that most prominent representative of twentieth-century Yoruba cultural power, Wole Soyinka, might sardonically describe such search for timeless purity as "neo-Tarzanism"?)

Time passed. Kamari Maxine Clarke's recent account of all this had aroused my curiosity, and so, several decades after the founding of Oyotunji Village, when for other reasons I was not so far away from it, I made my own one-day visit there. Indeed the brightly painted single-story houses, with their corrugated zinc roofs around the sandy village square, looked rather like something out of contemporary West Africa. In a moment, a village elder appeared on a bike and agreed to take me around for a modest fee. Wearing a brocade full-length tunic and a folded bag-like cap with short braids sticking out, he looked credibly Yoruba, and he took me to the shrines of different Yoruba gods. At the square where we began, there was a small shrine to Eshu, the trickster, where beer, soft drinks, and candy had been sacrificed, in turn attracting flies and spiders. At one shrine after another, my guide seemed most eager to point out to his foreign visitor that his religion was not that different-all these gods are really much like Christian saints, intermediaries between earthlings and a high god-and do we not all care for our ancestors? He seemed a bit puzzled when this particular visitor turned out to have his own notions of Yoruba religion. On an occasion like this, at least, it appeared that my guide was not so intent on showing that his religion was altogether different.

The tour was not entirely focused on religion. On a wall next to the shrine of Yemoja, female water deity, there was a wall with a painted list of the names of famous women in the history of Africa and its diaspora, ranging from Nefertiti to Josephine Baker, the early twentieth-century entertainer, and Coretta Scott King, widow of Martin Luther King. In a way, Oyotunji Village had perhaps become more of an African American theme park.

Next to the Eshu shrine, close to a gift shop, the village bulletin board also hinted that the rejection of America was hardly entirely complete. It showed various newspaper clippings about how Oyotunji had drawn the attention of the surrounding society. One was about 
a television appearance of the first oba, the late Adefunmi (who had now been succeeded by one of his sons), on the Oprah Winfrey Show, where he had tried to convince the famous talk show hostess about the advantages of polygamy. (I can imagine Oprah's response.)

On my walk with the village elder, I found the pathways very quiet. I learned that there were not so many permanent resident households left in the village. For people who needed to earn their income in the world outside, the location was inconvenient. Oyotunji has its continued ups and downs, but apparently it had to become more a place to visit, less a place to live. ${ }^{9}$

As it happened, my visit to Oyotunji Village was just a few days after the 2008 American presidential election, and the United States had just elected its first Black president: Barack Obama, Afropolitan Number One. Obama's paternal grandfather had been another "Burma Boy," recruited in his native Kenya to serve the British as they fought their late colonial World War II battles in Southeast Asia. ${ }^{10}$ Evidently he was older than most, and the cook for a British officer in Burma and elsewhere rather than a regular soldier. But this traveling experience may have mattered as he sent a son, the new president's father, to go and further his education in faraway United States.

So those precise days may not have been a time when most Black Americans were so inclined to give up on their country.

\section{Notes}

1. Price's (1973) edited book on the Maroons offers a richly varied view of the Maroon populations of the Americas, their history, and the way they were described by contemporary observers.

2. The book The Black Jacobins (1938), by the Trinidadian, Black British writer C. L. R. James, about the Haitian Revolution, is an early classic of Black literature: a remarkable work combining social history with event history, local history with transcontinental history. James, active through many decades, remains a central figure in Black Atlantic intellectual history and political thought; the Nigerian American literary and media scholar Akin Adesokan (2011: 56) concludes that "today, as postcolonial intellectuals confront similar problems of making homes and careers in expatriation, the experiences of James and his contemporaries are relevant and useful." I heard James speak once, at the University of Pittsburgh in the early 1970 s.

3. I have touched on the Surinamese presence in Amsterdam in an earlier essay (Hannerz 1996: 140-149).

4. We could also remember again Zora Neale Hurston's encounter with a formerly enslaved person, Cudjo Lewis, who had come from Ouidah to 
Alabama, as referred to in chapter 2, note 1-resulting in the belatedly published, biographical Barracoon (Hurston 2018). In 2019, the New York Times reported that the wreck of that last slave ship Clotilda, on which Cudjo Lewis had arrived in America, had apparently been found a few miles up the Mobile River, close to the neighborhood known as Africatown, established by formerly enslaved people at the end of the American Civil War (Fausset 2019).

5. The Internet web entries on the Gullah and Geechee are by now many and continually changing. See also Matory's (2015: 177-230) critical scrutiny of understandings of Gullah historical isolation.

6. I draw in what follows on Margaret Wade-Lewis's (2007) biography of Turner.

7. The Alake of Abeokuta, traditional chief, asked Turner if he could help his son get to a college in the United States; if that really happened, it would be the beginning of another Afropolitan. As far as Turner's further career in the United States was concerned, it would finally take him to a position at Roosevelt University, Chicago, a recently established institution catering to a multiethnic student body. Here, in 1958, as Prime Minister Kwame Nkrumah of newly independent Ghana visited Chicago, Lorenzo Dow Turner was one of his hosts. Turner retired officially in 1966, and died in 1972.

8. Commander (2017: 173-219) discusses the Gullah/Geechee as well as Oyotunji Village more briefly in her transdisciplinary study of the reawakened interest in African culture among Black Americans, noting for one thing the early doubts about the village among longer-time residents in the area. In another recent monograph on Yoruba-inspired religion in the New World, focusing on Trinidad, Castor (2017: 158-166) briefly describes a visit by Oba Adejuyigbe Adefunmi II, the son of the founder of Oyotunji Village and his successor as chief there, at a Trinidadian, strongly transnational, ritual event in 2012.

9. In an article published a few years after her monograph, Kamari Maxine Clark (2007) also notes that Yoruba religious revivalism has become increasingly based on the networks of a transnational diaspora rather than on any particular local site.

10. On Burma Boys from Nigeria, see chapter 14. Barack Obama's (2004: 408-409) early book Dreams from My Father (with a first edition published in 1995), including a description of his own rather youthful journey back to his deceased father's homeland in western Kenya, portrays his grandfather's character and life experience. Obama (2004: 382) also notes that one of his Kenyan kinsmen quoted Chinua Achebe to him: "When two locusts fight, it is always the crow who feasts." One may read Obama's own account of his Kenya journey, and then reflect on David Remnick's (2010: 62) comments on where it fits into his passage to the presidency-where Remnick also describes Obama's father's life after returning to Kenya as that of a "been-to," struggling to reconcile the mindsets of home and the West. Remnick, editor of the New Yorker magazine, has his understanding of the been-to from the Ghanaian writer Ayi Kwei Armah, and it fits well with what was said in chapter 7 about the been-to as a mid-twentiethcentury tragic figure. 


\section{References}

Adesokan, Akin. 2011. Postcolonial Artists and Global Aesthetics. Bloomington: Indiana University Press.

Castor, N. Fadeke. 2017. Spiritual Citizenship. Durham, NC: Duke University Press.

Clarke, Kamari Maxine. 2004. Mapping Yoruba Networks. Durham, NC: Duke University Press.

- 2007. "Transnational Yoruba Revivalism and the Diasporic Politics of Heritage." American Ethnologist 34: 721-734,

Commander, Michelle D. 2017. Afro-Atlantic Flight. Durham, NC: Duke University Press.

Fausset, Richard. 2019. "Vestige of Evil, Symbol of Pride.” New York Times (International edition), 28 May.

Haley, Alex. 1976. Roots. New York: Doubleday.

Hannerz, Ulf. 1996. Transnational Connections. London: Routledge.

Hurston, Zora Neale. 2018. Barracoon. New York: HarperCollins.

James, C. L. R. 1938. The Black Jacobins. London: Secker \& Warburg.

Matory, J. Lorand. 2015. Stigma and Culture. Chicago: University of Chicago Press.

Obama, Barack. 2004. Dreams from My Father. New York: Three Rivers Press. Price, Richard (ed.). 1973. Maroon Societies. Garden City, NY: Anchor Books.

Remnick, David. 2010. The Bridge: The Life and Rise of Barack Obama. New York: Knopf.

Turner, Lorenzo Dow. 1949. Africanisms in the Gullah Dialect. Chicago: University of Chicago Press.

Wade-Lewis, Margaret. 2007. Lorenzo Dow Turner. Columbia: University of South Carolina Press. 



\section{Index}

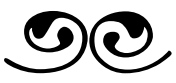

Aba, 63

Abacha, Sani, 100, 101, 103n2, 117, 193, 194, 202

Abani, Chris, 18n1, 74

Abeokuta, 33, 35n1, 52, 79, 125, 216n7

Abuja, 11, 18, 73, 76, 132, 135, 178, $186,197,199$

Accra, 45, 69, 105

Achebe, Chinua, 2, 7, 9, 12, 17, 19, 31, 36n6, 47-50, 55n1, 61, 62, 74, 77, 78, 82, 85, 86n2, 87n14, 94-95, 103n2, 112n3, 153, 156-157, 169-170, 174, 182, 186, 216n10

Adamu, Yusuf, 20

Addis Ababa, 155

Adebayo, Ayobami, 18n1

Adeeko, Adeleke, 18

Adefunmi, 213-215

Adenle, Leye, 18, 108

Adesokan, Akin, 22n29, 215

Adichie, Chimamanda Ngozi, 9, 13, 17, 19n8, 73, 75n4, 84, 85, 96, 150-153, 167, 182-186, 191n2, 209

African Commentary, magazine, 170

African Concord, newspaper, 169

African Writers Series, Heinemann's, 16, 23n36, 147, 205

Afro-Brazilians, 38-44, 68, 163, 195, 207

Afrocentrism, 209

Afropean, 21n19

Afro-Pessimism, 100

Afropolitan, Afropolitanism, 8, 20n17, 21n25, 109, 147, 163, 164, $177,191,210,213,215$
Agadès, 32

Ahmadu Bello, 63

Ahmadu Bello University, 86, 136-137, 143n4

Akiga Sai, 134-135

Akure, 23n33

Alhajis, 137, 141

Almajiri, 138, 140, 147

Aluko, S. A., $18 \mathrm{n} 1$

Amado, Jorge, 42

Aminu Kano, 157

Amsterdam, 209, 215n3

Anatsui, El, 87n13

Anderson, Benedict, 6-7, 45n6, 189

Andersson, Ruben, 21n25

Andrikopoulos, Apostolos, 21n25

Angola, 210

Anifowose, Remi, 87n6

Anthropology, colonial, 13, 15

Appiah, Kwame Anthony, 192n5

Armah, Ayi Kwei, 216n10

Asad, Talal, 23n35

Autoethnography, 11, 22n27

Awolowo, Obafemi, 116, 117n2, $148 \mathrm{n} 3$

Azikiwe, Nnamdi, 10, 21n21, 55n3, $80,83,164,211$

Baba of Karo, 129-134

Babangida, Ibrahim, 116, 120, 196, 202, 204

Badagry, 199

Baikie, William Balfour, 59-60

Baker, Josephine, 214

Baldwin, James, 50, 169, 189

Baltimore, 183, 191n2 
Bandele, Biyi, 146-147, 153

Bane, 200

Bastide, Roger, 45n4

Bauchi, 136-139, 198

Bayreuth, 79

Beaufort, SC, 212

Bedford, Simi, 21n 20

Been-to, 4-5, 21n20, 36n7, 90-97, 114, 136, 142, 147, 185, 216n10

Beier, Ulli, 36n4, 77-79, 86, 137, 212

Benin, 83, 155, 199, 202

Benin, Republic of, 193, 199

Berghe, Pierre van den, 78, 86n3, $87 \mathrm{n} 11$

Berlin, 188

Biafra War, 7, 16, 49, 55, 80, 81, 85, $87,146,149-161 \mathrm{n} 29$

Biobaku, Saburi, 85, 87n14

Birmingham, 9

Birnin Kebbi, 62

Birom, 115, 117n1, 198

Black British, 17, 205

Black Orpheus, 77

Bohannan, Laura, 22n28, 129

Boko Haram, 101, 103n6, 140, 197

Bond, Catherine, 101

Bookshops, 15-17

Bori cult, 133-135

Borno, 101

Borrioboola-Gha, 59

Bowen, Elenore Smith, 22n28, 129

Brazil, 38-44, 190, 207, 212

Britain, 90, 93, 94, 205

British Museum, 126

Brussels, 188-189

Buffalo, University of, 109

Buhari, Muhammadu, 116, 130, 145, 186, 202, 204

Bukuru, 154

Burma Boys, 52, 146, 215, 216n10

Bush concept, 5

Busia, Kofi, 53

Calabar, 199, 204

Calabar, University of, 55, 203

Callaway, Helen, 65n2

Cambridge University, 22n31, 36, $55 n 3,136$
Cameroon, 8, 191, 198

Campbell, Joseph, 36

Canetti, Elias, 190

Cape Coast, 57

Cape Town, 31, 167

Cary, Joyce, 62

Cassava Republic Press, 18, 108, 178, 187, 206n2

Castor, N. Fadeke, 216

Cesaire, Aimé 77

Chad, 142, 143n6

Chase, James Hadley, 183, 203

Chatwin, Bruce, 45n1

Chibok, 101-102, 141

Chicago, University of, 211

Chinweizu, 122, 127n5

Chua, Amy, 173-174, 175n11

Clark, John Pepper, 19n1, 164-167, 174n4, 177, 183, 184, 191, 199, 202

Clarke, Kamari Maxine, 213, 216n9

Clough, Raymond Gore, 63

Cobham, Rhonda, 22n31

Cohen, Robin, 19n7

Cole, Teju, 9, 13, 18, 74, 96, 117, 187-191, 207

Cologne, University of, $55 \mathrm{n} 3$

Columbia University, 20n12

Commander, Michelle, 216

Congress for Cultural Freedom, 86

Conrad, Joseph, 62

Copenhagen, 146

Cosby, Bill, 170

Creole languages, 3-4, 212

Creolization, 4, 19

Crowder, Michael, 148n2

Crowther, Samuel Ajayi, 58, 65n1

Cuba, 208, 213

Cultural imperialism, 3

Dahomey, 40

Daily Service, 115

Daily Times, 16, 115, 203

Dallas, TX, 10

Dallas TV series, 5

Dangote, Aliko, 20n14

Darnton, John, 98, 103n1, 106

Darnton, Nina, 103, 106-108

Dartmouth College, 56 
Daura, 130

Derrick, Jonathan, 23

Detroit, 213

DeWitte, Marleen, 21n25

Dickens, Charles, 13, 59

Dike, K. O., 87n11

District officers, 6, 48, 49, 62, 63-64

Domoslavski, Artur, 103n3

Dunham, Katherine, 213

Dyula, 210

East, Rupert, 134

East London, University of, 206n2

Ebonics, Black American dialect, 184

Ede, Amatoritsero, 21

Efik, 199

Egbuna, Obi, 19n1, 93-94, 97n1

Ekwensi, Cyprian, 2, 12, 55n1, 66-73, $82,96,106,108,112 \mathrm{n} 3,139$, 153-155, 174, 179, 195, 198, 207

Emecheta, Buchi, 18n1

Emenyonu, Ernest, 55n1, 82, 87n8

Emezi, Akwaeke, 23n32

Enugu, 50, 67, 79-81, 90-93

Equiano, Olaudah, 164, 174n2

Eshu, trickster, 126, 214

Essien, Kwame, 45n4

Ethiopia, 209

Evaristo, Bernardine, 9-10, 18n1

Eze, Chielozona, 21n19, 22n29

Faber and Faber, 18, 31, 73, 130

Fabian, Johannes, 19n6

Fagunwa, D. O., 20n15

Fairweather, Linda, 105

Fardon, Richard, 31

Ferrey, Ashok, 75n3

Fillitz, Thomas, 127n6

Financial Times, 127n1

Finland, 114

Folarin, Tope, $175 \mathrm{n} 8$

Folomi, 142

Forde, Daryll, 35n1, 87n14, 130

Forsyth, Frederick, 161n1

Fourth Dimension Publishers, 80, 87n6, 90, 157, 203

Frazier, Franklin, 166

Frobenius, Leo, 122-124, 127
Fulani, 137, 140, 167, 198

Furniss, Graham, 20n15

Future scenarios, 173, 174, 175

Gabon, 156

Garvey, Marcus, 164

Gates, Henry Louis, 22n31

Gbadamosi, Gabriel, 206n5

Gbulie, Ben, 161n1

Geechee, 210

Gehrmann, Susanne, 21

George Mason University, 103

Germany, 188

Ghana, 7-8, 21n25, 166, 192n5, 209, 216n7

Ghosh, Amitav, 22-23n31, 161

Gikandu, Simon, 22n31

Gilroy, Paul, 43

Giwa, Dele, 120, 127n2

Globalization, 3

Gola, 210

Golden, Marita, 175n10

Goldie, George Taubman, 60

Gombe, 102, 138

Goody, Jack, 36n5

Gordon, Jane Anna, 19n7

Gorer, Geoffrey, 36n8

Gould, Michael, 161n1

Gowon, Victoria, 190

Greatbatch, Bruce, 65n3

Greene, Graham, 34

Griswold, Wendy, 18n1, 87n8, 106

Guangzhou, 10

Gullah, 210-212

Habila, Helon, 102, 103n5, 143n3

Hair, P. E. H., 50

Haiti, 209, 213

Hajj, 137, 142

Haley, Alex, 209

Harcourt, Lewis Vernon, 6

Harlem, 190

Harris, Ashleigh, 21n19

Hart, Keith, 11, 13, 36n5

Harvard University, 173, 211

Hausa, 2, 8, 10, 20n12, 20n15, 28, 44, $62,64,71,102,130-134,136,145$, $160,171,197,198,204$ 
Hemingway, Ernest, 169

Henderson, Richard, 87n10

Herskovits, Melville, 45n4

Hiskett, Mervyn, 141, 143n7

Hodapp, James, 21n20

Houphouet-Boigny, Felix, 42

Houston, TX, 10

Howard University, 93, 211

Hughes, Langston, 165

Hurston, Zora Neale, 45n1, 215n4

Ibadan, 31, 32-33, 39, 50, 53, 76-79, 166, 196, 203

Ibadan, University of, 76-77, 78, 115, 196

Ibrahim, Abubakar Adam, 18

Ife, 44, 123

Igbo (Ibo), 2, 3, 7, 8, 14, 15, 19n4, 19n8, 20n15, 23, 35n2, 47-55, 66, $71,80,81,82,83,84,94,145,149-$ $158,167,170,172,174,179-181$, $182,193,204$

Ighavini, Dickson, 106

Ijaw, 164, 193

Ike, Chukwuemeka, 74n2, 84, 85, 87n12, 96, 155-156

Ikenne, $113,117 \mathrm{n} 2$

Ikoyi, 43, 98, 107, 112n3, 200, 201, 206n4

Ilorin, 202

Imagined communities (nations as), 7,163

Imoagene, Onoso, 175n12

Index on Censorship, journal, 205

India, 4, 6, 157

Indirect rule, 6, 101, 130

International Africa Institute, 14, $35 n 1$

Iowa, University of, 31, 93, 160, 173

Ireland, 41, 45n2, 205

Irele, Francis Abiola, 48

Irish missionaries, 41

Isa Muhammadu, Emir of Jemaa, 150

Isichei, Elizabeth, 55n2, 87n10

Ivory Coast, 155

Iwalewa-Haus, 79

Iweala, Uzodinma, 30, 161
Iyayi, Festus, 18n1

Jamaica, 124, 209

James, C. L. R., 215n2

Jemaa, Emirate of, 64, 101, 133

Jerusalem, 142, 190

Johannesburg, 99-101

John, Elnathan, 18, 140, 142-143n4

Jonathan, Goodluck, 112n4, 161n3

Jones, G. I., 14, 15, 36n5

Jos, 1, 66, 147, 154, 198

Julien, Eileen, 20n16

Kaduna, 1, 15, 63, 65, 71, 72, 75n3, 147, 154, 202

Kafanchan, 1-2, 3, 12, 15-16, 18, 19n3, 28, 63-65, 81, 101, 103n2, $119,130,133,135,141-142$, 144-148, 149-150, 196

Kagoro, 150

Kalamazoo, MI, 187

Kalu Mazi (Karl Marx), 169, 180

Kano, 11, 32, 111, 134, 140, 147, 151, 197

Kanuri, 102, 131

Kapuscinski, Ryszard, 98-99, 103n3, 121

Katsina, 140

Kennedy, John F., 163

Kenya, 215, 216n10

Kenyatta, Jomo, 53

Khruschev, Nikita, 165

Kincaid, Jamaica, 161

King, Coretta Scott, 214

King, Martin Luther, 214

King, Walter Eugene, 213

Kinshasa, 107

Kopytoff, Jean, 45n5

Krings, Matthias, 135n6

Kuti, Fela, 34, 79, 98, 107

Lagos, 1, 6, 11, 17, 18, 32-33, 38-44, 51, 58, 66-74, 76, 80, 91, 101, 106-111, 124, 139, 151, 167, $169,175,179,181,182,183,184$, $185,186,187,188,191,200,201$, 204-205, 212

Lagos, University of, 167 
Laird, McGregor, 57

Lander, Richard, 57

Landes, Ruth, 45n4

Larsson, Stieg, 105, 111

Last, Murray, 20n12

LeClézio, J. G. M., 82-83, 87n9

LeVine, Robert, 175n12

Lewis, Cudjo, 215-216n4

Libreville, 156, 157

Lincoln University, 21n21, 84

Lindfors, Bernth, 18n1, 35n1, 36n6, $74 \mathrm{n} 1$

Lisbon, 42

Literary anthropology, 11-15, 22n27

Lokoja, 57-61, 139, 202

London, 17, 50, 74, 104, 126, 194, 201, 206n5

London, University College, 130

London Review of Books, 206

Lubeck, Paul, 143n5

Lubumbashi, 78

Lugard, Frederick, 5, 14, 19n11, 35n1, 60, 71, 101, 146

Lundkvist, Artur, 28, 32-34, 79, 148n4, 195

Mabanckou, Alain, 164

Macaulay, Herbert, 58

Madiebo, Alexander, 87n6

Magdeburg, 188

Maiduguri, 1, 62, 102, 195, 197, 202

Maier, Karl, 103n2

Maitatsine upheaval, 140, 147

Maja-Pearce, Adewale, 23n36, 116, 147, 200-206

Makerere University, 20n12

Mali, 21n19, 183, 189

Mamdani, Mahmood, 20n12

Mamiwatas, 111, 171, 179

Manyika, Sarah Ladipo, 18, 177, 186, 198, 208, 209

Maroons, 207, 209, 210, 215

Masquelier, Adeline, 135n6

Massachusetts, University of, 170

Mathews, Gordon, 21n23

Matory, Lorand, 43-44, 45n6, 86n4, $117,175 \mathrm{n} 8,216 \mathrm{n} 5$

Mayflower School, 113, 115, 117
Mbari Club, 78, 86, 120, 165

Mbembe, Achille, 8, 20-21n18

Mbue, Imbolo, 191n1

McGreal, Chris, 100

Mecca, 9, 139, 141

Mexico, 190

Meyer, John W., 19n10

Minna, 66

Moberg, Vilhelm, 174n1

Modernization theory, 3

Molusi College, 114

Moore, Carlos, 79

Moore, Gerald, 35n4

Morley, John, 61

Morrison, Toni, 119

Mphahlele, Ezekiel, 77, 86n2

Muhammed, Murtala, 98

Na'Allah, Abdul Rasheed, 206n1

Nader, Laura, 13

Naipaul, Vidia, 189

Naming, of cities and countries, 6

Native authorities, 6

Navajo Indians, 53, 172

Ndibe, Okey, 12, 17, 148n4, 168-172, 179-182, 186, 191n3

Nebraska, University of, 15

Netherlands, 21n25

New Haven, 183

New Nigerian, 16, 137

New Orleans, 9

New York, 10, 179-182, 187, 188, 201

New York magazine, 179

Newell, Stephanie, 18n1, 48

News media correspondents, 98-103, 204

Newswatch, 127n2

Ngugi wa Thiongo, 164

Niger Delta, 57, 102, 158, 168, 190, 193, 200

Nigeria Magazine, 127, 145, 148

Niven, Rex, 63

Nixon, Richard, 165

Nkrumah, Kwame, 7, 21n21, 216

Nobel Prize, 34, 119-120, 142, 143n8, 189, 190, 206

Nollywood, 5, 103, 197

Northwestern University, 53 
Nsukka, 55n3, 84-85, 87n7, 87n13, 92, 150-153, 166, 183, 184, 196

Nupe, 60, 198

Nwankwo, Nkem, 86n5

Nwankwo, Victor, 80

Nwapa, Flora, 18n1, 19, 80, 157-158

Nyamnjoh, Francis B., 31-32, 36n7

Nzekwu, Onuora, 54, 96, 144-145

Nzimiro, Ikenna, 55n3

Obafemi Awolowo University, 148

Obama, Barack, 186, 190, 215, 216n 10

Obama, Michelle, 101

Obasanjo, Olusegun, 79, 125

Obiechina, Emmanuel, 22n31, 82, 87n7, 94

Obioma, Chigozie, 14-15, 23n33, 193

O’Brien, Edna, 103n6

Odù 77

Ogali, Ogali, 81, 90

Ogbu, John, 55n3

Ogoni, 193-194

Oguta, 158

Ohio State University, 18

Ojukwu, Odumegwu, 161n2

Okafor-Omali, Dilim, 49-52, 61, 79

Okara, Gabriel, 18n1

Okeke, Uche, 148n3

Okigbo, Christopher, 85

Okonjo-Iweala, Ngozi, 161

Okorafor, Nnedi, 109-111, 195

Okot P'Bitek, 167

Okpara, Michael, 161n2

Okparanta, Chinelo, 160

Okri, Ben, 14, 18n1, 34, 74, 111

Olinto, Antonio, 38-42, 79, 124, 207

Olopade, Dayo, 103n4

Olympio, Sylvanus, 42

Onishi, Norimitsu, 103n1

Onitsha, 10, 20n15, 58, 70, 81-83, 87n8, 90, 94, 96, 145, 154, 203

Onuzo, Chibundu, 73-74, 100, 195

Onwuachi, Chike, 55n3

Onyeama, Dillibe, 80

Oreh, O. O., 19n9

Organisation of African Unity, OAU, 155
Orizu, Nwafor, 21n21, 174n3

Osogbo, 43, 78, 86n4, 107-108, 196

Osondu, E. C., 178

Osu cult slaves, Igbo, 19n8, 94

Ottenberg, Simon, 55n3

Ouidah, 40-42, 45n1, 215n4

Oyo, 44, 213

Oyotunji Village, 212-215

Papua New Guinea, 78

Paretsky, Sara, 105, 111

Paris, 17, 42, 164

Park, Mungo, 57

Park, Robert E., 96

Pedraza, Howard, 57, 60, 61

Pelecanos, George, 105

Perham, Margery, 19n11

Philadelphia, 183

Piot, Charles, 174n5

Pitts, Johny, 21n19

Pittsburgh, University of, 215n2

Plotnicov, Leonard, 206n3

Pointe-a-Pitre, 164

Popoola, Olumide, 206n2

Port Harcourt, 6, 50, 51, 55n3, 70, $79,102,153,159,160,178,194$, 196, 200

Portuguese empire, 40

Presence Africaine, 17, 41, 77, 127

Price, Richard, 215n1

Princeton University, 165-167

Probst, Peter, 86n4

Prospect journal, 206

Providence College, 178

Pyeongchang, 10

Pym, Barbara, 35n1

Quartey, Kwei, 195, 112n2

Quayson, Ato, 20n12, 22n31, 45n4

Quilombos, 207

Ransome-Kuti, Funmilayo, 34, 79

Rastafarians, 209

Reed-Danahay, Deborah, 22n27

Remnick, David, 216n10

Rio de Janeiro, 190

Robinson, Marilynne, 160

Rome, 190 
Roosevelt University, 216

Rosy Guest Inn, 15-16, 149

Royal Military Academy, Sandhurst, 10

Royal Niger Company, 60

Royal West African Frontier Force, 146

Rubenfeld, Jed, 174

Rushdie, Salman, 96, 97n3, 161

Russia, 158

Salvador de Bahia, 38, 124, 207, 210

San Francisco, 177-178, 189, 209

Santeria, 209

Saro-Wiwa, Ken, 30, 85, 158-160, 193-195, 206n1, 212

Saro-Wiwa, Noo, 195-200, 203

School of Oriental and African Studies, London, 143n6, 187, 212

Selasi, Taiye, 8, 9, 21n19, 96, 164, 178

Selma, AL, 190

Senegal, 182, 190

Senghor, Leopold, 42, 77

Sesay, Isha, 103n6

Shaw, Flora, 6

Shekau, Abubakar, 140

Sheringham, Olivia, 19n7

Sierra Leoneans, 44, 45

Singapore, 173

Skinner, Ryan, 21n19

Slavery, 54, 133, 163-164, 199, 208, 209

Smith, Abdullahi, 137

Smith, Daniel Jordan, 112n5

Smith, M. G., 130

Smith, Mary, 130-134

Sokoto, 50, 140

Solarin, Sheila, 113-114, 117

Solarin, Tai, 113-117, 198

Soyinka, Wole, 12, 19n1, 22n31, $31,34,36 \mathrm{n} 6,77,78,79,86 \mathrm{n} 2$, 86n4, 96, 97n3, 116, 119-126, 142, 170-171, 174n6, 189, 193, 194, 199, 206n1, 207, 214

Spahr, Juliana, 86n2

Spengler, Oswald, 124

St. Paul, MN, 10

Steinbeck, John, 169
Stewart, Charles, 19n7

Stockholm, 23n33, 119, 120, 122, 186

Straits Times, newspaper, 173

Strauss, Franz Josef, 79

Studying sideways, 13, 105

Sudan, 143n6

Suhr-Sytsma, Nathan, 20n16

Sukur, 197

Suleija, 1

Surinam, 209, 215n3

Surulere, 107, 206

Sweden, 119-120

Tafawa Balewa, Abubakar, 151, 198

Tahir, Ibrahim, 36n5, 134, 198

Tay, Simon, 173

Taylor, Charles, 199

Texas, University of, 31

Third culture kids, 20n17

Thomas, Dylan, 30, 35n1, 73, 212

Thomas, Northcote W., 15

Timbuktu, 202

Times Literary Supplement, 203

Tiv, 22n28, 129, 130, 134, 198

Togo, 39, 42, 123

Tonkin, Elizabeth, 22n26

Toussaint L'Ouverture, 209

Tranströmer, Tomas, 189, 192n4

Tribe, tribalism, 149

Trinidad, 216

Trump, Donald, 174n5, 186

Turner, Lorenzo Dow, 19n6, 45n4, 211-212, 216n7

Tutuola, Amos, 2, 18, 20n15, 23n33, 28-35, 50, 58, 66, 79, 87n14, 93, $130,148 \mathrm{n} 4,159,167,212$

Uchendu, Victor, 49, 50, 52-55, 158

Uimonen, Paula, 19n1

Umuahia, 50, 85, 87n14, 92

United States, 10, 53, 119, 163-192

Urhobo, 164

Usman, Yusufu Bala, 136-137, 142n2

Usuman dan Fodio, 140, 141

Verger, Pierre, 45n4, 124-127

Wade-Lewis, Margaret, 216 
Warrant chiefs, Igbo, 49, 51, 52, $55 \mathrm{n} 2$

Warri, 168

Washington, DC, 93, 175n10

Wenger, Susanne, 77, 78, 86, 108, 196-197, 212

West Africa magazine, 17

West African Pilot, newspaper, 115

West African Sensation, newspaper, 67, 68, 72, 154

Wheatley, Paul, 86n1

White, Stanhope, 62

Whitehead, Colson, 45n1

Wideman, John Edgar, 170, 174n6

Wilson, Woodrow, 165

Winfrey, Oprah, 215

Wisconsin, University of, 55n 1

Works, John A., 143
World Cultural Heritage sites, 43, 78, 196

Yakö 35n1

Yale University, 134, 177, 183

Yamba, C. Bawa, 143n6

Yan iska, 140

Yola, 202

Yoruba, 2, 5, 8, 23, 35, 76, 84, 86n1, 107, 119-126, 167, 170, 172, 174, $187,191,198,201,204,213-214$, 216

Yousafzai, Malala, 101

Zaria, 16, 86, 130, 131, 136-137, 166, 188, 196, 198

Zimbabwe, 94

Zungeru, 83 